\title{
Religion and the Body
}

Modern Science and

the Construction of Religious Meaning

Edited by

David Cave \&

Rebecca Sachs Norris

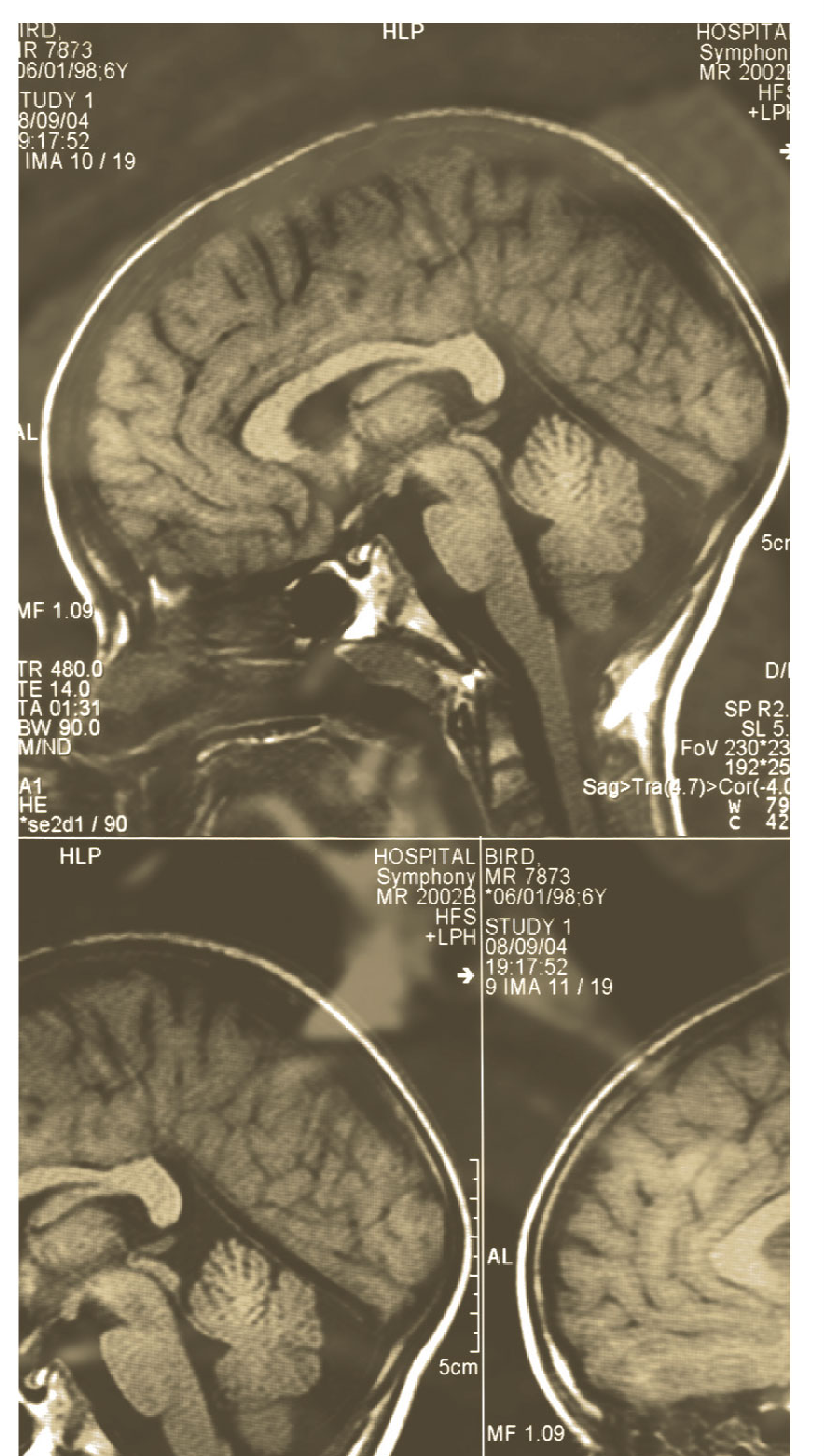

B R I L L 
Religion and the Body 


\title{
Numen Book Series
}

\author{
Studies in the History of Religions
}

\author{
Series Editors \\ Steven Engler (Mount Royal University, Calgary, Canada) \\ Richard King (University of Glasgow, Scotland) \\ Kocku von Stuckrad (University of Groningen, \\ The Netherlands) \\ Gerard Wiegers (University of Amsterdam, \\ The Netherlands)
}

VOLUME 138 


\title{
Religion and the Body
}

\author{
Modern Science and the Construction \\ of Religious Meaning
}

\author{
Edited by \\ David Cave \\ Rebecca Sachs Norris
}

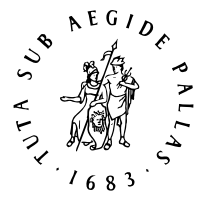

B R I L L

LEIDEN • BOSTON

2012 
This is an open access title distributed under the terms of the CC BY-NC 4.0 license, which permits any non-commercial use, distribution, and reproduction in any medium, provided the original author(s) and source are credited. Further information and the complete license text can be found at https://creativecommons.org/licenses/ by-nc/4.o/

The terms of the Cc license apply only to the original material. The use of material from other sources (indicated by a reference) such as diagrams, illustrations, photos and text samples may require further permission from the respective copyright holder.

An electronic version of this book is freely available, thanks to the support of libraries working with Knowledge Unlatched. More information about the initiative can be found at www .knowledgeunlatched.org.

Cover illustration: MRI scan of the human brain/head (Anonymous)

This book is printed on acid-free paper.

Library of Congress Cataloging-in-Publication Data

Religion and the body : modern science and the construction of religious meaning / edited by David Cave, Rebecca Sachs Norris.

pages $\mathrm{cm}$. - (Numen book series, ISSN 0169-8834; volume 138)

Includes bibliographical references and index.

ISBN 978-90-04-22111-6 (hardback : alk. paper) — ISBN 978-90-04-22534-3 (e-book)

1. Neurosciences-Religious aspects. 2. Neurobiology. 3. Religion and science. I. Cave, David, editor of compilation. II. Norris, Rebecca Sachs, editor of compilation.

BL255.R45 2012

201'.66128-dc23

This publication has been typeset in the multilingual "Brill" typeface. With over 5,100 characters covering Latin, IPA, Greek, and Cyrillic, this typeface is especially suitable for use in the humanities. For more information, please see www.brill.nl/brill-typeface.

ISSN 0169-8834

ISBN 9789004221116 (hardback)

ISBN 9789004225343 (e-book)

Copyright 2011 by the Authors. Published by Koninklijke Brill NV, Leiden, The Netherlands.

Koninklijke Brill NV incorporates the imprints Brill, Global Oriental, Hotei Publishing, IDC Publishers, Martinus Nijhoff Publishers and VSP.

All rights reserved. No part of this publication may be reproduced, translated, stored in a retrieval system, or transmitted in any form or by any means, electronic, mechanical, photocopying, recording or otherwise, without prior written permission from the publisher.

Authorization to photocopy items for internal or personal use is granted by Koninklijke Brill NV provided that the appropriate fees are paid directly to The Copyright Clearance Center, 222 Rosewood Drive, Suite 910, Danvers, MA 01923, USA.

Fees are subject to change. 
To Peggy,

Who believes faithfulness and focus reward not just marriage But creative efforts, too.

To Harry,

For putting up with me for so long, and with patience.

And in memory of Tom Idinopulos (1935-2010), friend and scholar. There to in-spire this project at its genesis. In-spirit at its end. 

CONTENTS

List of Contributors

Introduction .............................................................................................. 1

\section{SECTION ONE}

NEUROBIOLOGY AND SOURCES OF RELIGIOUS EXPERIENCE AND AUTHORITY

Reading the Body, Reading Scripture: The Implications of Neurobiology on the Study and Interpretation of Scripture ........ 15 David Cave

De/Constructing Transcendence: The Emergence of Religious Bodies James W. Haag and Whitney A. Bauman

Tongues of Men and Angels: Assessing the Neural Correlates of Glossolalia John J. McGraw

Synchronized Ritual Behavior: Religion, Cognition and the Dynamics of Embodiment 81 Sebastian Schüler

\section{SECTION TWO}

\section{CULTURE AND THE DE- AND RE-CONSTRUCTION OF THE BODY}

Religion, Neuroscience and Emotion: Some Implications of Consumerism and Entertainment Culture 105 Rebecca Sachs Norris

Every Story is a Ghost: Chuck Palahniuk and the Reenchantment of Suffering 
Attaining Transcendence: Transhumanism, the Body, and the Abrahamic Religions

Arthur Saniotis

SECTION THREE

(CROSS) CULTURAL APPROPRIATIONS OF THE BODY

Magnetism and Microwaves: Religion as Radiation

Deana L. Weibel

Scientific Approaches to the Body in the Spiritual-Physical Marketplace

Mira Karjalainen

Sleep Deprivation: Asceticism, Religious Experience and Neurological Quandaries

Núria M. Farré-i-Barril

Sikhism and Mental Illness: Negotiating Competing Cultures 235 Jagbir Jhutti-Johal

Bibliography

Index 


\section{LIST OF CONTRIBUTORS}

Whitney A. Bauman, Ph.D., (2007) Theology/Religious Studies, Graduate Theological Union, authored Theology, Creation and Environmental Ethics (2009), and co-edited Grounding Religion: A Field Guide to the Study of Religion and Ecology and Inherited Land: The Changing Grounds of Religion and Ecology.

David Cave, Ph.D. (1989), Regional Director, University of Michigan, has published widely on the phenomenology and comparative study of religion, including Mircea Eliade's Vision for a New Humanism (1993) and The Role of the Authoritative in the Comparative Process (2006).

Núria M. Farré-i-Barril (Ph.D. in process on evil and penance in Medieval theology/culture) is lecturer of History of Religions at the University of Lleida. She studied history, theology and anthropology at the University of Lleida and at the EHESS in Paris.

James W. Haag (Ph.D., Graduate Theological Union) is Lecturer in Philosophy at Suffolk University. He is author of Emergent Freedom (Vandenhoeck and Ruprecht 2008) and lead editor of The Routledge Companion to Religion and Science (forthcoming).

Jagbir Jhutti-Johal, DPhil (1999), University of Oxford, is Lecturer in Sikh Studies, University of Birmingham. Her search encompasses gender and Sikhism, science and Sikhism and contemporary Sikhism. Publications include: Sikhism Today (2011); "The Role of Women in their Religious Institutions" (2010).

Mira Karjalainen, Ph.D. (2007), Comparative Religion, University of Helsinki, University Lecturer at University of Helsinki, is currently Secretary of Finnish Society for Study of Religion. Publications include "In the Shadow of Freedom" (2007) and articles on religion, fieldwork and ethics.

John J. McGraw possesses a Ph.D. in Anthropology and Cognitive Science from the University of California, San Diego. His work focuses on the intersection of cognition and culture with a special emphasis on ritual theory. 
Rebecca Sachs Norris, Ph.D. (1999) in Religious Studies/Anthropology, Boston University, is Associate Professor of Religious Studies at Merrimack College. Her publications include Toying with God: The World of Religious Games and Dolls (2010) and articles on religion, neuroscience and body.

Eric Repphun (Ph.D., Otago 2009) is Associate Lecturer in religion at the University of Otago in Dunedin, New Zealand. He is the co-founder of the journal Relegere: Studies in Religion and Reception.

Arthur Saniotis, Ph.D. is a Visiting Research Fellow in the School of Medical Sciences at The University of Adelaide. His research interests include evolutionary medicine, medical anthropology, futures studies and comparative religion.

Sebastian Schüler (Ph.D., University of Münster 2010) is postdoctoral researcher in "Religion and Politics" at the University of Münster, Germany. His research has focused on sociological and cognitive theories of religion, aesthetics of religion and global evangelical Christianity.

Deana L. Weibel, Ph.D. (2001) in Anthropology, UC San Diego, is Associate Professor of Anthropology at Grand Valley State University. Her publications include "Malinowski in Orbit: 'Magical Thinking' in Human Spaceflight" (2006) and "Of Consciousness Changes and Fortified Faith" (2005). 


\section{INTRODUCTION}

\section{David Cave and Rebecca Sachs Norris}

It is clear to any observer of contemporary society that there is a widespread interest in neurobiology, the study of our brain and of our genetic constitution. Spurred by the biological revolution underway since the nineteen-thirties and the focus on the brain since the nineteen-nineties, this interest constitutes, in the words of Mircea Eliade, a "cultural fashion," touching many dimensions of our daily life, from determining how we vote, choose careers and mates, make ethical decisions, cure disease, treat mental disorders, investigate the nature of happiness, to, at its most ambitious, extend human life. ${ }^{2}$ From the time of Darwin to today, we have made enormous strides in refining our ability to study how we are constituted as human beings and are connected to nature. The neurological revolution has taken this refinement to a new level, whereby humans are looked at less in the abstract as defined and shaped by society or sacred forces than as extensions of nature, of neurons and synapses and strands of DNA.

The conceptualization of the body as electro-chemical processes operating in a bounded locus of matter, the "naturalized body," is so deeply embedded in the 21st century Western worldview, hidden by our own enculturation, that we are often unaware of how much this conceptualization shapes our discourse on religion and our studies of the body and religion. In this series of essays as case studies, we aim to elucidate some of the underlying perspectives on the naturalized body that are foundational to contemporary religious scholarship and practice, and examine their implications on religious meaning. Whether the assumptions and findings of modern science are found useful, as in neuroscientific modeling, or controversial, as in concepts of transhumanism, or become a negotiable part of the fabric of 21st century religion, as seen in Sikh attempts to

${ }^{1}$ Eliade, Mircea. "Cultural Fashions and the History of Religions," in Symbolism, the Sacred, and the Arts. Ed. Diane Apostolos-Cappadona. NY: Crossroad, 1985, 17.

${ }^{2}$ Judson, Horace Freeland. The Eighth Day of Creation: The Makers of the Revolution in Biology. NY: Simon and Schuster, 1979, 10 and the proclamation at the Library of Congress website: http://www.loc.gov/loc/brain/proclaim.html for the decade of the brain, 19902000 . 
mediate traditional and bio-medical views of mental illness, will depend on how well we can reconcile concepts of the naturalized body with the shape and color of modern religiosity.

We realize there is no such thing as an objective standpoint, and that the hardest enculturated worldviews to understand are our own, since we are embodied inside them, and they are embodied inside us. As scholars, it is nonetheless vital for us to reflect on the influence of our own worldviews on our scholarship as well as in the academy. Here, we address this need through consideration of the interaction between science (primarily neurobiology) and religious narratives, focusing on the ways that scholars of religious studies have approached the body in light of the underlying metaphor of the naturalized body - the body understood as a biochemical organism.

While the role and experience of the body in religion is a growing topic, as yet there has been little, if any, consideration of how specifically this understanding shapes contemporary religious practice and scholarship. This lacuna is somewhat surprising, given that the preponderant assumption of work on the body and religion in the mid- to late-2oth and early 21st centuries has been shaped by the perspective of the naturalized body as much as by Western religious practice and modes of thought. We see this tendency in diverse places, from current interest in cognitive and neuroscientific studies to how pilgrims explain to themselves and others the transcendent force of pilgrimage sites—-seen as divine, electrical force lines, or both.

Our knowledge of bodies at the cellular level is far from complete. We are only at the beginning of understanding the mystery that is our brain and body. Despite our limited knowledge, there is much that we can say about how we are constituted and enough confidence to form hypotheses regarding the most intangible qualities of our existence: consciousness, love, compassion, the emotive pull of the aesthetic, and beliefs in that which we cannot see nor our senses can take in. As we advance in our discoveries and gain increasing confidence in our science, scholars from fields as diverse as philosophy, psychology, anthropology, and theology posit explanations and interpretations of one of the most puzzling and persistent of human aspirations: the need and desire to find meaning.

For the religious, meaning is articulated through belief, story, ritual, ethics, and ineffable experiences-bodily all. Indeed, there is no study of religion without a study of the body. Religious experience is irreducibly an experience of the body. No component of religious life is unat- 
tached to the body. ${ }^{3}$ Even the most abstract theological and metaphysical speculations are informed by sensorial experiences of and in the world, that in turn become enculturated in contemplative, ecstatic, painful, ${ }^{4}$ and mundane practices. The performing of rituals, the entering into ecstatic trances, the choosing of courses of action and of behavior, the decorating of one's body, and the wearing of vestments to symbolize authority and position, these, too, bring the body into play. Then there is the way in which distinctions of gender and sex inform religious behavior, thought, and experience. Even the collective body, a grouping of people of like mind and heart, articulate a physical and mental dynamic en masse. Regardless of how we study the body, there can be no distinction between the body and the practice of religion. For in the end, religion is inexorably a human construction. And to be human is to be embodied.

Most believers, with some detractors, would agree that religion is tied to the body. Fewer would go so far as to say it is a product of the body. But the equation that humans are interconnected with nature and that religion is itself so interconnected, goes back to Lucretius and Spinoza, respectively. It would be the evolutionary views of Darwinism, though, that most shaped the modern world's general conceptualization that humans are tied to nature, such that today naturalism, taking the mind (brain) and body as one, has become the prevailing philosophical position. ${ }^{5}$ In the words of Charles Taylor, this naturalism gets its extension in an "exclusive humanism," ${ }^{6}$ a humanism that levels the hierarchies of old (religious) orders and defines humans within an enclosed system of natural laws. Religion or, more broadly, the search for meaning, is not necessarily eliminated in this secular world in which this humanism exists, but it is assuredly affected.

Putting aside fundamentalist or dualist religious conceptions that reject naturalism altogether, most religious sensibilities today are this-worldly in nature, in the sense of recognizing an immanent, versus a purely transcendent, spirituality and meaning structure. This focus on immanence has turned from traditional authorities (of scripture and religious institutions)

3 Sullivan, Lawrence. "Body Works: Knowledge of the Body in the Study of Religion," History of Religions, 1990, 86-99, and LaFleur, William R. "Body," in Mark C. Taylor, Ed. Critical Terms for Religious Studies. Chicago: University of Chicago Press, 1998, 36.

${ }_{4}$ Norris, Rebecca Sachs. "The Paradox of Healing Pain." Religion 39, no. 1 (2009), 22-33.

5 De Caro, Mario and David McArthur, Naturalism in Question. Cambridge, MA: Harvard University Press, 2004, 6-7.

${ }_{6}$ Taylor, Charles. A Secular Age. Cambridge, MA: Harvard University Press, 2007, 19-21 and following. 
toward other authorities, notably the authorities of nature and of science for finding one's spiritual authenticity. ${ }^{7}$

As these religious expressions evince a turning toward the natural world, neurological and biological sciences are making path-breaking discoveries all the while into the minutest recesses of our body and garnering attention within the scientific community, the academy, and society generally. Says Alva Noë, of the Institute of Cognitive and Brain Sciences at Berkeley,

We live in a time of growing excitement about the brain. Only the preoccupation with finding the gene for everything rivals today's widespread optimism regarding all things neuroscientific. Perception, memory, our likes and dislikes, intelligence, morality, whatever-the brain is supposed to be the organ responsible for all of it. It is widely believed that even consciousness, that Holy Grail of science and philosophy, will soon be given a neural explanation. In this era of expensive and flashy new brain imaging technologies (such as functional magnetic resonance imaging and positron emission tomography), hardly a day goes by without the science pages of our leading newspapers and magazines publishing reports of important breakthroughs and new discoveries. ${ }^{8}$

This cultural fascination with our brain (and with our genes) feeds not just our curiosities but also informs economic and public policy models for society, carrying the ancient maxim "know thyself" into concrete, implementable solutions for human betterment.

However much our "secular age" possesses more alternatives to religion than ever before, ${ }^{9}$ people still look for that which gives them meaning and hope for tomorrow. The biological and neurological revolutions of today are no different in their contributions to this hope. They offer constructs of meaning and salvific promises not unlike the most transcendent of religions. It is surprising, then, given the interest in the neural and biological sciences, that there has yet to appear a volume that explores the implications of this interest on the nature and study of religion. Such a study is long overdue.

Most books to date on religion and the body have by and large studied the body from without, through the interpretive parameters of gender, politics, sociology, cultural studies, economics, history, and sexuality.

\footnotetext{
7 See Taylor's chapter, "Religion Today," in A Secular Age.

${ }^{8}$ Noë, Alva. Out of Our Heads: Why You Are Not Your Brain, and Other Lessons from the Biology of Consciousness. NY: Hill and Wang, 2009, xi.

9 Taylor, Secular Age, 3.
} 
With developments in micrography, microengineering, and, especially, in computerized imaging, ${ }^{10}$ spurred by new analytical assumptions (e.g. the body contains language "memes"), we are now able to investigate the body from within, not according to its static constitution (as in anatomy), but in process and in vivo. Through functional Magnetic Resonance Imaging (fMRI) we can track the activity of emotions and of individual ethical choices in "real time," revealing up-to-the-minute readings of the human at work, as it were. We can study, with increasing levels of precision, the effects of prayer, meditation, and religious ecstasy; the role of emotion and of feeling from acts of compassion, sacrifice, and of conversion; and the significance of belief and religious narratives. Even aging and the wear and tear of the body are arrested (ostensibly for a period at least) by injecting the body with mega doses of vitamins and synthetic pharmacological drugs and by implanting mechanical "biobots" into our cavities and bloodstreams.

In religious studies, advances in ethnographic findings bring into greater relief how human bodies in different cultures and religions know differently, inspiring new reflections on meaning, identity, and religious knowledge. Moreover, discoveries into the brain and our genes confirm with ever greater precision the now-standard assumption that how we see and experience the world is preconditioned by our bio-chemical bodies.

As such, students of religion and of science-and believers themselves-are pressed to carry further the interrelationship between science and religion. Some approaches subsume religion into science, others science into religion. Whichever the direction, these orientations are inherently reductionist, certainly in terms of explanation, and in some cases they are descriptively reductionist. Some argue that religious experiences are merely neuronal states, others that subjective experience of unknown provenance trumps materialist causation. Indeed, the reifying of subjective, religious experiences is held by many theologians and scholars of religion to differentiate religious experience from all other types of experiences, as Ann Taves notes in her recent work, Religious Experience Reconsidered. ${ }^{12}$ Then there are those who aim to reconcile neuroscience

\footnotetext{
${ }^{10}$ Ewing, William A. Inside Information: Imaging the Human Body, London: Thames and Hudson, 1996, 9-10.

${ }^{11}$ Biological nanotechnology robotics. See biobots.org.

${ }_{12}$ She asserts that it is not essentially different from other experiences deemed special, instead that it is the attribution of religious meaning rather than other meanings that makes it a religious experience. There is nothing that makes religious experience
} 
and religion, saying at core they are compatible: "In this book we explore ways in which the workings of the brain correspond with people's understanding of the divine," say James B. Ashbrook, and Carol Rausch Albright in The Humanizing Brain: Where Religion and Neuroscience Meet..$^{13}$

We seek in this volume to reflect on the implications of the growth and influence of these discoveries as well as the underlying scientific viewpoint on the practice and study of religion. We certainly do not claim to cover all of the dimensions of the embodiment of religion, but we do address a number of critical components on the relation of modern science to religious meaning, looking at such topics as the locus of religious authority, the neurological basis of transcendence, the reductionism of religious belief, the appropriation of spiritual practices for commercial consumption, the emotive power of religion and its exploitation, the limits of science for interpreting religious suffering, and the futuristic implications of neurobiology on religious belief and practice. Each chapter takes a particular aspect of the larger theme of the embodiment of religion. The view of religion as embodied within a naturalistic framework coheres the diversity of subjects herein presented and sets the book apart from other books on religion that treat the body more as a supernatural or sociopolitical entity.

The volume is comprised by three sections: I) Neurobiology and Sources of Religious Experience and Authority; II) Culture and the De- and Re-Construction of the Body; and III) (Cross) Cultural Appropriations of the Body. The first section provides some of the theoretical undergirding of the subject, particularly on matters of the authoritative basis for validating and speaking about belief, practice, and experience; on the provenance and interpretation of feelings and imaginings of transcendence and its manifestations in community life, and on the matrices of inputs that legitimize the transformative nature of ritual. The second section handles theoretical implications of the body in contemporary (and future) social contexts, on how the body is 'de' and 're' constructed such that religious

exceptional or sui generis different from other kinds of non-ordinary experience, instead "[w] hether people consider a special thing as (say) 'religious,' 'mystical,' 'magical,' 'superstitious,' 'spiritual,' 'ideological,' or 'secular' will depend on the preexisting systems of belief and practice, the web of concepts related to specialness, and the way that people position themselves in a given context." Taves, Anne. Religious Experience Reconsidered: A Building Block Approach to the Study of Religion and Other Special Things. Princeton \& Oxford: Princeton University Press, 2009, 162-3.

${ }^{13}$ Ashbrook, James B. and Carol Rausch Albright. The Humanizing Brain: Where Religion and Neuroscience Meet. Cleveland, OH: The Pilgrim Press, 1997, xxii. 
emotion is appropriated by consumer culture, on how pain is neutered by modern medicine and exalted by religious communities, and on how human life is extended to the point that traditional religious definitions of the body become anachronistic. And the third section carries the subject into specific practices and other cultures, looking at how religious believers creatively interpret for personal meaning and therapeutic goals their sensorial perceptions of sacred places, how the religious and the non-religious translate ancient spiritual practices for secular objectives, how modern life and religious disciplines interpret asceticism differently, and how one particular non-western religious community incorporates (or does not) modern, scientific assumptions of the body.

In the opening chapter of section one, David Cave in "Reading the Body, Reading Scripture: The Implications of Neurobiology on the Study and Interpretation of Scripture," looks at how 'scripture,' that most critical and authoritative of sources for religious communities, has been challenged if not supplanted by modern neurological readings of the body and their naturalistic assumptions. For centuries, biblical scripture, taken to be revealed, has vied for authoritative status with readings of other 'scriptures,' notably the scriptures of nature, secular history, and secular literature, says the textual scholar of religion, Wesley Kort. Cave claims that the modern revolution in neuro-biology presents a new 'scriptural' authority that we are to read for defining who we are as human beings and how we can and ought to live: the reading of the human body itself. If, indeed, there is this new scriptural authority, how, then, does traditional scripture maintain its legitimacy in the context of naturalistic assumptions of reading the body for defining what constitutes the human and for determining what we ought to become? In taking the reading of scripture as analogous with the reading of the body (through fMRIs, PET, and CAT scans) and by turning to the philosophical grounding of Spinoza, Cave believes scripture holds its legitimacy within a naturalistic framework.

James Haag and Whitney Bauman in "De/Constructing Transcendence: The Emergence of Religious Bodies," position the construction of meaning, which they refer to as "meaning-making," at the juncture of and within the very process of the co-emergence of mind/body, nature/culture, transcendence/immanence in the evolution of matter and religion. They argue that these seemingly dualistic polarities are neither dualistic nor polar but in fact are integrated, each giving rise to the other while being different. Drawing on the French philosophers Gilles Deleuze and Felix Guattari and the anthropologist and neuroscientist Terence Deacon, among others, Haag and Bauman aim to rescue religious experience from the slight and 
reductionism to which certain prominent scientific critics and naturalistic philosophies have subjected it. At the same time, they want to retrieve religious experience from being co-opted, as it has been for most of its history, by theological, philosophical, and spiritual-ecological orientations that discount the role that "matter" plays in meaning-making. As they say, “...'mattering' is directly connected with 'meaning-making,' which we take to be a central feature of all religions...."

In "Tongues of Men and Angels: The Neural Correlates of Glossolalia," John McGraw utilizes neuroscientific analyses of speaking in tongues, glossolalia, a largely evangelical practice of "unintelligible utterances by the inspired speaker," to demonstrate that neuroscience need not be reductionist. He instead brings into relief how glossolalia balances and interrelates potentially competing interpretations, those of modern psychology and those of the Pentecostal religious community. McGraw says, "... glossolalia promotes neural and behavioral disinhibition, specifically disinhibition resulting from selective downregulation of circuits in the prefrontal cortex of the brain . Further, this neurologically significant property-its ability to engender a typically mild altered state of consciousness-helps to illuminate the ritual purpose of speaking in tongues. Glossolalia creates a state of mind that facilitates transitions between oppositional cultural values." In short, by drawing on modern science, McGraw does not brush or explain away a practice puzzling to outsiders, but rather gives it authoritative credibility as an enactment of religious meaning.

In the last chapter of this section, Sebastian Schüler, in "Synchronized Ritual Behavior: Religion, Cognition and the Dynamics of Embodiment," focuses not on a specific communal practice but takes a more general look at ritual behavior, showing how ritual "highlight[s] the interdependent relations between the brain, the body, and the social world." Ritual is synchronic behavior. It is interactive and collective, synchronizing social and individual neurological mechanisms. As such, it brings together various neural and bodily actions together in time, as part of a single action that forms and is formed by religious worldviews. "The dynamics of ritual synchronization determine particular body-schemas through which we perceive and interact with the world, and which shape the embodied experience of ritual participants. Moreover, through body-schemas ritual participants embody the collective meaning of the ritual performance," says Schuler. Meaning, therefore, has ultimately a synchronizing fluid quality to it, evident in both the stories we tell for ourselves and in the rituals we carry out. 
The contributions in the second section of this volume move from theory to context. The first one, "Religion, Neuroscience and Emotion: Some Implications of Consumerism and Entertainment Culture," segues from the first section by applying neuroscientific understanding of emotion to contemporary consumer/entertainment culture. Rebecca Sachs Norris demonstrates that the neurobiological underpinnings of emotion parallel experience, providing interdisciplinary insight not only into the structure of emotion, but also into the process of enculturation. She focuses on a particular quality of emotional experience - that emotion is re-experienced, or refelt, when it is evoked through memory. Religious traditions have made use of this characteristic to educate or train specific feelings and experiences. The contemporary insistence on passion and superficial authenticity, both modeled and reflected in popular media, train us to a different emotional life, however. She notes that "our emotional structure is still the same as it has been for millennia; the sensory images and bodily postures we see around us form neurological associations and shape our emotional lives, but the material that is informing that process has changed significantly." Norris asks "Could it be that immersion in consumer culture makes it difficult or impossible to engage with demanding spiritual disciplines?" and proposes that through the contributions of neuroscience we can see that the contemporary western ethic of 'easy' emotions may indeed weaken the ability to engage in inner disciplines required of religious practice.

Eric Repphun, in "Every Story is a Ghost: Chuck Palahniuk and the Reenchantment of Suffering," addresses the difference between pain and suffering through the work of American cult writer Chuck Palahniuk. Palahniuk affirms the concept of the naturalized body but moves beyond it. "At the same time that he [Palahniuk] affirms the truth of the fully rationalized understanding of the human body dominant in modern biomedicine, he rejects absolutely conventional biomedical ideas about the value of physical pain and suffering," says Repphun. Repphun states that the ability of Palahniuk's characters to reclaim agency in their experiences of pain and suffering-through such means as bare-knuckle boxing, staged automobile accidents, and acts of self-mutilation-is possible because "pain and suffering are matters not only of individual human bodies but also of culture." These willed forms of suffering also serve to create authentic human communities for those living at the very edges of society, and they do so partly through the process of embodied reenchantment, which Repphun defines not as a reversal of disenchantment 
resulting from rationalization (Weber) but rather as a surfacing or resurfacing of enchanted elements within modernity. In this transformation, pain and suffering are not simply constructed by a medicalized, biochemical perspective, but instead, drawing on "forgotten or undervalued understandings of suffering rooted in the history of the Christian tradition," "take on transformative, even subversive meaning."

In "Attaining Transcendence: Transhumanism, the Body, and the Abrahamic Religions," Arthur Saniotis concludes this section by positing a totally new re-construction of the body through an exploration of transhumanism, "a school of thought which contends that future humans will be radically different due to technological forays into the human body and brain." He contends that while there is resistance to technologically altered bodies within the Abrahamic traditions (albeit not universally), transhumanism, like spiritual transformation, is an attempt to improve or perfect human beings. Transhumanists believe that greatly enhanced technologies of the near future will benefit humans not only physically, but also cognitively, which, in turn, will benefit our ability to deal with ecological issues. While the theologies and anthropologies of the Abrahamic religions have significant concerns with transhumanism, Saniotis argues that even with these there are considerable similarities and shared values between transhumanism and the Abrahamic traditions in that both "privilege the body with attaining transcendent dimensions."

The third and final section carries the subject into specific practices, considering how practitioners negotiate cultures and how a particular practice can be understood from two cultural worldviews: religious and scientific. The first chapter in this section, "Magnetism and Microwaves: Replacing Religion with Radiation," results from fieldwork in Rocamadour, France, a site of pilgrimage for both traditional pilgrims and 21st century pilgrims who understand the site as sacred because of the existence of special "geobiological" energies. Drawing on ethnographic testimonials of pilgrims to Rocamadour, Deana Weibel shows how pilgrims turn to Catholic or quasi-scientific or a diversity of religious traditions, sometimes all three, to explain how these energies do in fact exist and are felt and to define what they mean for one's own spiritual development and broader connection to nature and to sacred sites generally. By taking seriously the believers' interpretations with her own objectivity as an ethnographer and anthropologist, Weibel balances the authority of the practitioner with the insights of science to demonstrate that the construction of meaning moves between interpretation and explanation, effects and causes, the conceptualization of the ineffable and the experience of the material. 
In the next chapter, "Scientific Approaches to the Body in the SpiritualPhysical Marketplace," Mira Karjalainen, looking at yoga and Asian martial arts such as Japanese budō and Chinese taijiquan, traces how traditional religious practices of embodiment, of disciplined and coordinated bodily movement, are translated from how they were initially conceived, as integral elements of a spiritual practice, to fit our consumer, secular society's views of spirituality and embodied meaning. For example, people will take up yoga because they've started experiencing back-aches, are undergoing too much stress, or because they simply want a particular type of exercise. Focusing on physical-spiritual exercises is valuable because they correspond so well with the perspective of the naturalized body and the associated "subjective turn" that practitioners make when they view their bodies "as genuine (re)sources for knowledge and experiences." The globalization of these practices, though, raises questions about how authentic these reconceptualized practices are to the cultures and religions from which they originated. Those who practice yoga and the martial arts, for instance, must eventually "negotiate the spiritual dimensions of the art into their [own] belief systems." Those who teach courses on these practices are often aware of this need of the practitioners. Instructors will bring in, mostly for the advanced classes, the traditional philosophical or spiritual dimensions of the practice. But the interweaving of religion and science is complex and fluid. "Paradoxically," says Karjalainen, "Eastern practices often endeavor to legitimize these arts in the eyes of the cosmopolitan consumer culture by employing Western scientific rhetoric."

Núria Farré-Barril advances the investigation of the relationship between religious practice and scientific research in "Sleep Deprivation: Asceticism, Religious Experience and Neurological Quandaries." In this chapter she compares religious and neuroscientific perspectives on the ascetic practice of sleep deprivation. Unlike Karjalainen's previous chapter, where there appears to be a growing convergence between past and present, religious and secular, in Farré-Barril's study the contrasting polarities don't converge so readily. "The highest virtues of sleep deprivation, according to religious interpreters, are turned into severe pathologies and dysfunctions, according to medical scientists," she says. Religious practitioners from diverse eras and traditions-e.g. Taoists, Navahos, the Desert Fathers, and modern followers of the Nocturnal Adoration movement-have practiced sleep deprivation as a source of spiritual growth. The meaning of this form of asceticism draws on religious understandings of sleep and waking. Neuroscientific studies of sleep deprivation, on the other hand, embedded in the medical model of the naturalized 
body, do not see inherent value in sleep deprivation, but instead find in it organic harm. It is the very organic abnormality of this practice (that one would deprive one's body of its natural desire for sleep) that gives the religious interpretation its justification. Seen as religious, symptoms resulting from sleep deprivation, such as hallucination, are taken not as pathological but as "divinely inspired." Despite the fact that we live in a scientific worldview, for many the construction of religious meaning often goes counter to this worldview, as Farré-Barril points out.

In the final chapter, similar to the preceding study, Jagbir Jhutti-Johal, in "Sikhism and Mental Illness: Negotiating Competing Cultures," examines the divide between traditional religious interpretations and medical scientific ones as seen from within a specific cultural framework: a community of Sikhs in Great Britain. Medical science views mental and emotional illness as "a symptom of a chemical imbalance, brain disease or due to some psychological trauma." In contrast, for traditional Sikhism, these mental states are not due to biological causes but to religious ones. It "views [mental and emotional illness] as a physical manifestation of a disease of the soul and spirit... to be cured by meditation and leading a God-centered life." One type of meditation, nam simran, spiritual meditation on God's name, central and vital to Sikh religious practice, figures prominently as a ritualistic approach to addressing mental illness.

Sikhs have not generally entered into the science/religion debate with respect to health issues-in large part because of a cultural reluctance to discuss matters of health, especially mental health, since it is subject to taboos and stigma. Older Sikhs are more likely to rely on traditional explanations and practices to address mental illness, but younger Sikhs live across cultures, and may make use either of traditional or medical interventions, or even both. Those living in modern western countries must negotiate as well the competing cultures of the religious versus the western-medical and the differences between the generations on whether to draw upon religious or scientific treatments of mental health. JhuttiJohal shows us the complexity of thinking through the implications of the embodiment of religious meaning within a given religious tradition and in regard to a particular type of illness.

From out of these case studies, we hope readers will explore lines of inquiry beyond those we raise here and see in these essays a resource, a platform, for stimulating further discussions on the modern scientific view of the body and the construction of religious meaning. 
SECTION ONE

NEUROBIOLOGY AND SOURCES OF RELIGIOUS EXPERIENCE AND AUTHORITY 



\title{
READING THE BODY, READING SCRIPTURE: \\ THE IMPLICATIONS OF NEUROBIOLOGY ON THE STUDY AND INTERPRETATION OF SCRIPTURE
}

\author{
David Cave
}

This paper considers what the neurobiological reading of the body implies for the reading of scripture. By 'the neurological reading of the body' I refer to how modern science and culture draw upon cognitive science and genetics to explain and to understand what it means to be human. And by the 'reading of scripture' I refer to the practice of the various religious traditions to understand our humanity based on claims of inspired and revealed insights, said to come from some agency transcendent to our naturalized mind and body. I contend that within a naturalistic system these two readings are not mutually exclusive but interrelate such that the reading of one informs and illumines the reading of the other.

Among many quarters, the reading of the body has come to rival, even replace, the reading of scripture (and here I refer to scripture broadly understood, of no particular religious tradition) for defining and guiding us in what it means to be a human being. In a recent opinion piece in the New York Times, columnist David Brooks, in "The Neural Buddhists," comments on the widespread interest in neuroscience and genetics and surmises that its proponents will not so much undermine a belief in God as undermine the claims of scripture. He says, "The atheism debate is a textbook example of how a scientific revolution can change public culture... and yet my guess is that the atheism debate is going to be a sideshow. The cognitive revolution is not going to end up undermining faith in God; it's going to end up challenging faith in the Bible." Brooks cites contemporary scientists such as Daniel J. Siegel, Michael Gazzaniga, Jonathan Haidt, Antonio Damasio, and Marc D. Hauser who claim that human consciousness and our values and emotions such as love, altruism, compassion, and fears of all sorts, are a product of our neural circuits and of the evolutionary adaptation of our genes to preserve the self and our species. The biologist Richard Dawkins clearly equates the biological reading of

\footnotetext{
${ }^{1}$ Brooks, David “The Neural Buddhists,” New York Times, May 13, 2008.
} 
the body to the reading of scripture when he says "DNA sequences are the gospel documents of all life, and we have learned to decipher them.." ${ }^{2}$ In other words, there is no need to consult scripture when we can find the good news (the gospel) for humanity in our genetic constitution. Brooks' observation and the claims of those he cites have their iconoclastic precursor in Darwin, whose theory of natural selection forever became the bête noire of scripture's account of the same, especially among those who purport a divine hand behind nature and human life.

Today, PET (Positron Emission Tomography) and CAT (Computerized Axial Tomography) scans and, particularly, functional MRIs (Functional Magnetic Resonance Imaging) have become the primary authoritative means by which the scientific community reads the body. ${ }^{3}$ These scans have taken on authoritative status not only among specialists but among the general public as well. Here, for instance, in Figure 1, we see an fMRI scan of the lateral frontal cortex of the brain from a study that tested changes in the function and structure of a patient's brain due to chronic pain. This study revealed that pain can affect the brain's volume of grey matter, thereby influencing one's capacity to think and emote. ${ }^{4}$

Michael Hagner, professor of science studies in Zurich, says that new types of imaging different from earlier scanning techniques, such as traditional X-Ray technology, are ushering in a new way to understand ourselves as human. "The situation has changed," he says. "Images of the brain produced by means of these techniques grace half or whole pages in glossy magazines and daily papers. They give the impression of opening a new window onto the functioning of the brain and hence also onto

${ }^{2}$ From Dawkins's book, The Blind Watchmaker (NY: W.W. Norton, 1986), quoted in Goldberg, Steven Seduced by Science: How American Religion Has Lost Its Way. NY: NY University Press, 1999, 125 .

3 The neuroscientist, Alex DaSilva, University of Michigan, who conducts research on the brain's response to stimuli, said to me when I visited his lab that fMRIs have been accepted as authoritative in depicting the brain as it really works. While its findings are not conclusive or without interpretive variation, fMRIs, he says, provide the most accurate rendering to date of the brain at work. And, from clinical trials, he says he has not come across anyone who does not accept the images of the brain as not being theirs; people did not contest the abstract scientific rendering of what they see as their brain. Nevertheless, despite the authoritativeness ascribed to fMRIs, interpretations derived from them, not unlike the many erroneous (and arrogant) interpretations of scripture, are not without errors and false claims. See The New York Times article, "The Scan that Didn't Scan," by Kolata, Gina (October 14, 2008).

4 DaSilva A.F., Becerra L., Pendse G., Chizh B., Tully S., et al. "Colocalized Structural and Functional Changes in the Cortex of Patients with Trigeminal Neuropathic Pain." PLoS $O N E_{3}$, no. 10 (2008): e3396. doi:10.1371/journal.pone.ooo3396. 


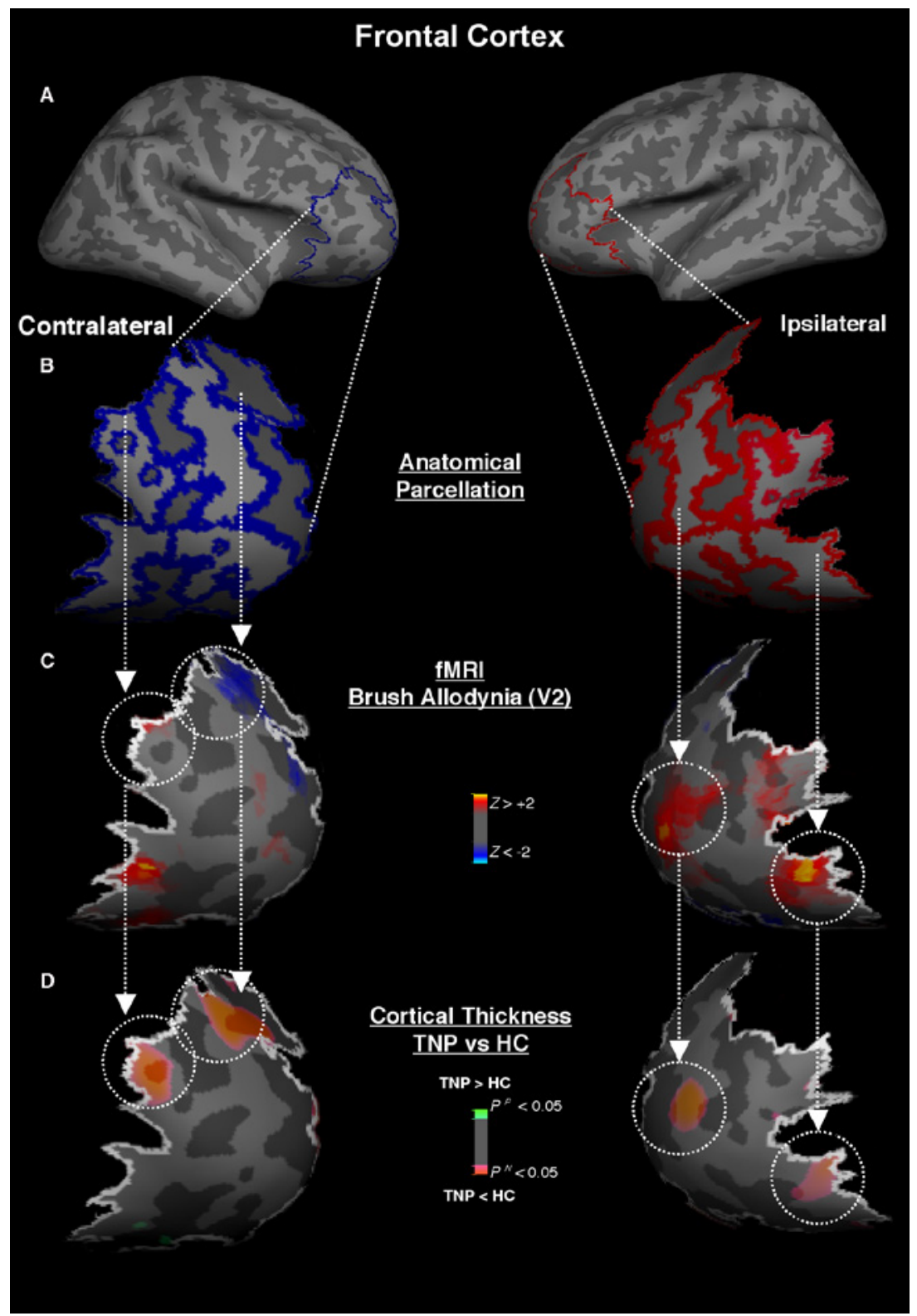

Figure 1. Frontal Cortex (Lateral). Panel A and B-The latero-frontal cortex was parcellated in seven sections. Panel C-BOLD (de)activation following allodynic brush stimulation in TNP patients showed bilateral activation in the frontal middle, and inferior gyri that extended in part to the frontomarginal cortex, as well as deactivation in the contralateral superior frontal sulcus. There was also bilateral activation in the posterior orbital gyrus. Panel D-Most of the functional clusters of allodynic (de)activation were precisely colocalized with cortical thinning. 
the mental life of man, an impression that captions and comments do their best to reinforce." ${ }^{5} \mathrm{He}$ adds, "in the history of the human sciences, innovations in visualization technology have affected the perception of the physical and mental nature of man. Neuroimaging has transposed psychological phenomena into visual categories and thus changed their epistemic and cultural status."

Barbara Stafford, an art historian at the University of Chicago, whose work as of late has focused on what neuroscience can shed on the act of perception, herself speaks of anatomical and neural visual images taking on the credibility of truth, as the image in pre-Enlightment literacy once did. We are following in a "conceptual and perceptual revolution," ${ }^{\prime \prime}$ she says, adding that we are in the "media age of vocal, aural, and, above all, optical rhetoric ..." ${ }^{8}$ Computer simulations and visualizations of the brain and of its nerve cells provide neuroscientists and cognitive psychologists literal insights into the brain as it thinks and responds to tactical, emotional, and visual stimuli, bringing into view what for human history has been formerly hidden. This move toward the visualization of knowledge "has broad intellectual and practical implications on the conduct and the theory of humanities, the physical and biological sciences, and the social sciences," she says. ${ }^{9}$ As such, it has implications on the reading of texts, hence, on the reading of scripture.

These advanced scanning techniques comprise a sub authority within the overall authoritative claims of modern science, which is one of the (primary) authorities affirming an immanental worldview in competition with traditional religion and its claims to transcendent truth. ${ }^{10}$ The legal scholar David Goldberg says the religious are often pressed now to articulate a response to science, an onus he attributes to the religious for having been "seduced by science," whereby they must now justify their beliefs and convictions on the basis of scientific claims rather than upon their own experience and reading of scripture. ${ }^{11}$ Goldberg defines and differ-

\footnotetext{
${ }^{5}$ Hagner, Michael. "The Mind at Work: The Visual Representation of Cerebral Processes," in Renee van de Vall and Robert Zwijnenberg, Eds. The Body Within: Art, Medicine, and Visualization. Leiden: Brill, 2009, 68.

${ }^{6}$ Ibid., 67.

${ }^{7}$ Stafford, Barbara. Good Looking: Essays on The Virtues of Images. Cambridge: MIT Press, 1996, 21.

${ }^{8}$ Ibid., 22.

9 Ibid., 23.

${ }^{10}$ See the philosopher of secularity Charles Taylor in his chapter "Religion Today" in his A Secular Age. Boston: Harvard University Press, 2007.

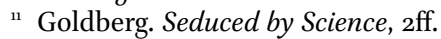


entiates science and religion too dualistically, but his point is taken. The reading of scripture can no longer be undertaken indifferent to the way science itself reads the world, that is, indifferent to the fact that human life and our neurobiological workings are inextricably tied to nature.

If we grant, though, the prevailing scientific and philosophical assumption that the world is what it is, that nature is all that we have-this being the prevailing philosophical premise for the past century, with historical roots to Aristotle - and we reject nature as a mirror of a transcendent, Platonic universe, then where does this leave scripture, generally thought ${ }^{12}$ to be revealed and to hold eternal truths for shaping the individual and communal life of millions of believers? How do we reconcile scripture as a ground and as a guide with the confident assumptions of cognitive science and evolutionary genetics and within the cosmology of naturalism?

\section{Reading the Body as Reading Scripture}

To begin to answer these questions, it is helpful first to correlate the reading of the body with the reading of scripture.

Wesley Kort, a textual scholar of religion, refers to three chronological stages through which the reading of scripture has progressed since the 16th century. In each of these stages scripture came to be read in relation to a particular textual field. This field was read first through the lens of scripture, then parallel to scripture as an authoritative text in its own right, and then in place of scripture, such that it, not scripture, became the principal authoritative text. Once each of these textual fields, operating as 'scripture,' got a toehold in general culture, scripture, the Bible particularly, came to be read in terms imposed by the newly dominant text. These textual fields were 'nature,' (secular) 'history,' and (secular) 'literature.'13 They received their validation as windows onto the sacred from wisdom biblical literature, which draws upon universal human experiences and moves readers' sights and emotional and aesthetic sensitivities outward toward

\footnotetext{
${ }^{12}$ I say 'generally' because, depending upon a person's orthodoxy, among some traditions, such as Hindu, Buddhist, and Jewish, later scriptures, commentaries, and sayings developed upon prior scriptures. Thus, there is no singular text in these traditions that speaks for all others; there is no singular authoritative scripture.

${ }_{13}$ Kort, Wesley. "Take Read": Scripture, Textuality, and Cultural Practice. University Park, PA: Penn State University Press, 1996, 37. The reading of "nature" as scripture was inspired by the philosopher Francis Bacon; of "history" by Giambattista Vico; and of "literature" by the writer Samuel Taylor Coleridge and the aesthetic philosophy of Immanuel Kant.
} 
the natural order and toward other, non-biblical, cultural creations. Nature, thought to capture the awe of the sacred, and its beauty, power, and predictable, rhythmic order, offers unmediated spiritual nourishment and a more expansive and inclusive vision than the special revelation of the Bible. Moreover, it is less prone to be manipulated by institutionallysectarian positions. It evades human trappings. ${ }^{14}$

'History' - specifically secular history, or history as opposed to mythis the domain through which we witness the outcome of human choices and the play of social, political, and economic forces upon the world stage. Through it we trace objectively the outcomes of human yearnings and attend to the structures and laws that make the living together of humans possible - or not. Despite the fact that the writing of history is not absolutely objective, secular history, as distinct from religious history, provides more of the raw data of human affairs that religious or sacred history - which carries an overlay of myth and a soteriological teleology ${ }^{15}$ - does not.

Unlike the reading of nature and of history, each of which could be read as texts of divine agency, revealing the handiwork of God, secular 'literature,' in contrast, is a purely human construction and must be justified on other grounds than that it reveals God's hand in human affairs. Ultimately, literature gets its rationale as an alternative scripture by linking the human aesthetic to divine perfection. We read literature to give us a window into our inner life and to nourish our imagination to see the world anew. ${ }^{16}$

Kort shows us that other texts—nature, history, literature-superseded (biblical) scripture by directing our sights outward from "new understandings of [the] biblical texts" to see the "larger world" in new ways. ${ }^{17}$ While traditional, canonical scripture has played and will continue to play a formative role in shaping modern culture, it has led us to read other texts that, through their reading, have become independent of scripture and now shape how we see our lives today and will see them tomorrow.

${ }^{14}$ Ibid., $43-45$.

15 Ibid., $57-58$.

${ }^{16}$ For a contemporary example of turning to secular literature to replace scripture as a source for constructing personal meaning, see Dreyfus, Hubert and Sean Dorrance Kelly. All Things Shining: Reading the Western Classics to Find Meaning in a Secular Age. NY: Free Press, 2011.

${ }^{17}$ Kort, “Take Read," 38. 
In speaking of 'nature' as a textual field, Kort defines it broadly, as applying to the whole of nature. For our purposes, though, it is possible to categorize neurobiology as a sub-field of the textual field of 'nature.' In effect, we can say that neurobiology, the reading of the human body, has become itself a scripture, a fourth textual field to Kort's three. It differs from previous readings of the body, that looked at the body from political, economic, racial, and gendered points of view, by the fact that the body is not read from without, as a product of society, but from within, as a product of nature.

What, though, do we mean by reading the body?

If to read means to scan (a text) for interpretation, or to interpret (a text) by scanning it, using the eyes, or, if blind, touch, then to read the body is to scan it, at various levels, to interpret what it is saying. By means of functional MRIs, PET, and CAT scans, and by deciphering the human genome, we read the body for its biological 'memes,' its inherent, evolutionary language that shows, at the most literal level, what makes us who we are and do what we do. Granted, our knowledge of how the body works is far from perfect. Conclusions about the brain and our genetic constitution, while advanced, are still quite provisional, but no more or less provisional than our interpretation of literary texts, particularly sacred texts. Just because our knowledge is provisional, be it in neuroscience or literary studies, that does not mean we cannot come to informed judgments of what a text or the body is saying. There is nothing that keeps us from speaking with confidence about a great deal and more guardedly about a great deal more. To read the body is analogously no different from reading a literary text.

In saying 'to read the body is analogously no different from reading a text,' I broach a contested distinction in the philosophy of hermeneutics: the distinction between "the study of persons and their cultural expressions from that of nature," as Wayne Proudfoot phrases it. ${ }^{18}$ The former, "the study of persons and their cultural expressions," has 'texts' as its object of study, whereas the study of 'nature' has empirical data as its object of study. Proudfoot, and those within the hermeneutical tradition, would not equate explaining nature with understanding a text or a cultural practice when it comes to questions of meaning. To explain how the brain reacts to pain cannot be equated with the statement that pain

\footnotetext{
${ }_{18}$ Proudfoot, Wayne. Religious Experience. Berkeley: University of California Press, 1985, 47 .
} 
is a form of suffering that brings us closer to God: the former provides the cause; the latter interprets it.

But we do not go through life as either biological or cultural beings; we are both at the same time. We are expressive bodies, and, so, must draw upon both the analytical and the interpretive tools of the natural and human sciences to understand ourselves as human beings. As the philosopher Owen Flanagan says, "The unification of the sciences that study persons [or human beings] is made possible by the insight that all these sciences ${ }^{19}$ are all engaged in studying various aspects of the thinking and being of a certain very smart species of social animal." ${ }^{\prime o}$

On equating, then, the reading of the body with the reading of a text, we can correlate the two in three ways: one, reading scripture is itself a neurobiological activity. When we read we engage the whole mind and body. Two, the body is itself a type of scripture. Whenever we read the body to learn about who we are as humans and what we can become, we regard what the body tells us as true and authoritative. And, three, the reading of scripture and the scientific view of reading the body have each influenced the other: the history of medicine and the study of gross anatomy developed in part through this interaction.

Turning to the first point, on the neurobiological connectedness between the body and scripture, scholars and historians of reading refer to the fully sensorial process of reading wherein the text is, in effect, 'ingested,' such that the text is taken into oneself, depending upon the intensity of the reading. ${ }^{21}$ "Reading," says the cognitive scientist, Maryanne Wolf, is "a neuronally and intellectually circuitous act, enriched as much by the unpredictable indirections of a reader's inferences and thoughts, as by the direct message to the eye of the text."22 The neuroscientist Stanislas Dehaene, in Reading In the Brain: The Science and Evolution of a Human Invention, argues that our capacity to read and write did not come as a

\footnotetext{
${ }_{19}$ Neuroscience, genetics, biochemistry, political science, sociology, economics, etc.

${ }^{20}$ Flanagan, Owen. The Really Hard Problem: Meaning in a Material World. Cambridge: MIT Press, 2007, 3.

${ }^{21}$ The classic line that captures this idea of 'ingestion' is from the English author and philosopher Sir Francis Bacon: "Some books are to be tasted, others to be swallowed, and some few to be chewed and digested: that is, some books are to be read only in parts, others to be read, but not curiously, and some few to be read wholly, and with diligence and attention." I want to thank the historian Elizabeth Eisenstein for alerting me to this quote.

${ }_{22}$ Wolf, Maryanne. Proust and the Squid: The Story and Science of the Reading Brain. NY: Harper Collins, 2007, 16.
} 
product of the brain's evolution. ${ }^{23}$ From the time of the first writing system $(5,400$ years ago $)$ and of the alphabet $(3,800$ years ago $)$ there has not been enough time for the brain to have developed to the point that it could undertake the highly complex act of reading. The brain had within itself already what it needed to learn the act of reading. It possessed built in genetic "constraints" and "cortical mechanisms" from the earliest huntergatherers that are specifically attuned for enabling us to read.

Although these constraints and mechanisms are fixed, they are plastic enough to allow the brain to adapt to new uses, such as to learn to read and write. ${ }^{24}$ With the mind 'constrained,' it not being a 'blank slate' totally malleable to what acts on it from without, our thinking can only work within a given set of parameters. So though cultures differ in how they read and write, there will nevertheless be a consistency among their texts because the human mind is only so malleable to cultural inputs. Discrepancies between texts, and, hence, between meanings derived from these texts, can only be so great since the brain itself is limited in its plasticity. The neuroscientist Michael Gazzaniga refers to this exchange between the brain (matter) and culture as the "interactionist view," whereby matter sets the structural boundaries and culture elaborates upon these boundaries through the use of the imagination. ${ }^{25}$

The body and scripture are related not only neurobiologically, through the sensorial act of perception, but analogously: the body is itself a book that reveals truth. Take one example. Many a person looks upon a disease that afflicts the body as a vehicle through which God is speaking, or through which some profound truth is to be discovered. The English poet and cleric John Donne (1572-1631), in the throes of an illness, read his body by probing his doctors with questions and by doing his own study on his illness so as to understand the disease for himself and to see in it the presence of God. Donne looked to his body to discover what was ultimate for him. ${ }^{26}$ His body's physiology was his 'scripture.'

We can also relate the reading of the body to the reading of scripture when we note that in the history of medicine the way scripture was read

\footnotetext{
${ }^{23}$ Dehaene, Stanislas. Reading in the Brain: The Science and Evolution of a Human Invention. NY: Viking, 2009, 6.

${ }^{24}$ Ibid., 4-5.

${ }^{25}$ Gazzaniga, Michael S. The Mind's Past. Berkeley: University of California Press, 1998, $236-37$.

${ }^{26}$ Barkan, Leonard. Nature's Work of Art: The Human Body as Image of the World. New Haven: Yale University Press, 1975, $5^{2}$.
} 
did much to shape how the body was understood. Writing on the advance of medicine in Europe during the late seventeenth and early eighteenth centuries, Jonathan Israel identifies three rival Enlightenment philosophical positions which differed, among other ways, in how they read the body in light of scripture. ${ }^{27}$ The dominant moderate Enlightenment (based on Locke and Newton) took scripture much as the church took it-as God inspired-and so proceeded cautiously and piecemeal in its medical advancements so as not to challenge too much the view of the body as anything but divinely created. The Radical Enlightenment (anti-Locke, anti-Newton, inspired by Spinoza, Bayle, and Diderot) rejected revelation and supernatural agency: the body's physiology functions only according to natural and physical causes. A Counter-Enlightenment, that denounced all positions that took God and Providence out of the picture,,$^{28}$ did little to advance the scientific study of the body, says Israel. Of the three, the Radical Enlightenment of Spinozism made the greatest contribution to the advancement of medicine and to the regard of the body. ${ }^{29}$ Spinozian naturalism regarded the body as intrinsically one with nature, subject to nature's laws. The body is to be read on its own terms, not through a religious sieve. ${ }^{30}$

So in claiming that we turn to the body to discover many of life's mysteries, we say that neurobiology contributes to the shaping of our religious worldview as do social, political, cultural, economic, linguistic, and historical influences..$^{31}$ The point is not to find proofs for the existence of

${ }^{27}$ Israel, Jonathan. "Enlightenment, Radical Enlightenment and the 'Medical Revolution,' of the Late Seventeenth and Eighteenth Centuries." In Ole Peter Grell and Andrew Cunningham, Medicine and Religion in Enlightenment Europe. Burlington, VT: Ashgate, 2007, 5 .

${ }_{28}$ Ibid., 5 ff.

${ }^{29}$ Ibid., 17-28. In Flesh and the Age of Reason: The Modern Foundations of Body and Soul. NY: W.W. Norton \& Company, 2003, Roy Porter shows how Christian views of the soul and of the self, during the seventeenth and throughout the eighteenth centuries, became more naturalized, more attached to the body and to the psychological reading of the mind as body. While the soul and self were not reduced to the body, this shift did mean that the mind, through reason, imagination, and education, had greater control over shaping one's being and destiny. Earthly existence had greater value as an end in itself and less the life hereafter. See $470 \mathrm{ff}$.

${ }^{30}$ It must be said, though, that religion was not necessarily anti-progress in the advancement of medicine. The medical historian Roy Porter notes that the beginning of the study of human anatomy through dissection "was justified largely in terms of natural philosophy and piety (the body demonstrated the wisdom of the Creator)." See, Porter, Roy. The Greatest Benefit to Mankind: A Medical History of Humanity. NY: W.W. Norton \& Company, $1997,132$.

${ }^{31}$ Strathern, Andrew. Body Thoughts. Ann Arbor, MI: University of Michigan Press, 1996, 2. See also Dennis Ford's identification of eight ways in which humans have sought to invest 
God and for our religious aspirations and motivations in our brain and genes - though there are those that do..$^{32}$ Rather, it is to recognize that the body constitutes an authoritative text from which we can learn how humans conceptualize meaning and make choices from that framework of meaning - or, as the case may be, how we fail to find the meaning we need to carry on..$^{33}$

\section{Reading the Body and Reading Scripture}

This shift in authority from scripture to the reading of the body does not necessarily mean scripture becomes irrelevant. ${ }^{34}$ What it does mean is that we take scripture as embodied, as rooted in humans' lived experience, mediated through the body. If it is so embodied, then we can assume a neurobiological linkage between readers of scripture today and the personages of old, given that, as biological beings, we are not (that) different from our predecessors.

In her Models of God: Theology for an Ecological, Nuclear Age, theologian Sallie McFague argues that we need to adopt a metaphoric theology that associates God's 'body' with nature, in contrast to the hierarchical,

life with meaning. Ford, Dennis. The Search for Meaning, A Short History. Berkeley, CA: University of California, Press, 2007.

$3^{2}$ See, Newberg, Andrew, M.D., Eugene D'Aquili, M.D., and Vince Rause. Why God Won't Go Away: Brain Science \& The Biology of Belief. NY: Ballantine Book, 2001, and, now the Director of the National Institute of Health (NIH), Collins, Francis. S. The Language of God: A Scientist Presents Evidence for Belief. NY: Free Press, 2006. As a counter to these claims, see Runehov, Anne L.C. Sacred or Neural? The Potential of Neuroscience to Explain Religious Experience. Gottingen: Vandenhoeck \& Ruprecht, 2007, 193-94. Can neural activity show (prove) the presence of God? Says Runehov, "No, neural activity of experiences of ultimate reality only show the presence of neural activity. It is not identifying any subject or object. Nor does the activity speak to its significance. Neuroscience lacks an 'appropriate method' for 'drawing ontological conclusions'." She also says, "Whatever we experience, and whether we understand our experiences or not, whether there is something outside our experiences or not, it is our brain and our mind that shape our world for us." But it is not just our mind, she adds: “... all religious experiences are interpreted according to the experiencer's social-cultural-religious-personal frame of reference in the same way that the brain creates other human experiences."

33 As the existentialist philosopher Albert Camus famously put it: "There is but one truly serious philosophical problem, and that is suicide. Judging whether life is or is not worth living amounts to answering the fundamental question of philosophy." Camus, Albert. "The Myth of Sisyphus." In Basic Writings of Existentialism. Gordon Marino, Ed. NY: The Modern Library, 2004, 441.

34 For an extended discussion on 'scripture' as authoritative and on what is 'authority,' see Cave, David. "The Role of the Authoritative in the Comparative Process," in Thomas Athanasius Idinopulos, Brian C. Wilson, and James Constantine Hanges, Comparing Religions, Possibilities and Perils? Leiden/Boston: Brill, 2006, 27-34. 
over-and-against-nature metaphor of kingship, the prevailing metaphor adopted throughout most of Christian history. In arriving at a new, less oppressive metaphor for our day, she aims to translate the teachings of scripture, as passed through tradition, for the conditions and demands of our experiences today. ${ }^{35}$ Scripture is not to be regarded as a set of norms that we are to press onto our historical period like a cookie cutter. Rather, she says, scripture is a "sedimentation of interpreted experiences," of models of those who sought to interpret and live out their life experience in the world as they understood it. These models, in turn, serve to guide us in interpreting scripture for our own place and time..$^{36}$ As these models are passed on through the institutions of our religious communities - the rabbinate, the sangha, the umma, the church — do they become available for future generations to be interpreted and applied to their own time and place.

Although McFague does not refer to the neurobiological character of our experiences, she does provide a useful model of the embodiment of scripture of which I speak. Referring back to Dehaene, the embodiment of scripture in our time implies that it is not only cultural sources (from writings, philosophies, art, etc.) which contribute to the formulation of meaning. Meaning is also formulated to the extent of our mind-body's evolutionary development. That is, biology interacts with culture, each influencing the other, not simply as the tired nature/culture debate, but in the sense that culture affects the development of our mind and body and that our neurobiological structure and mechanisms affect what we think, do, and create. Culture and biology emerge ${ }^{37}$ together. We truly do experience the world - of society and of nature - such that matter matters. As the neurologist Michael Gazzaniga phrases it, "the mind [our mental constructions] and body are so linked that it becomes impossible to talk about one without the other." ${ }^{8} 8$

Our flesh and blood embeddedness in the world does indeed shape how we think and feel and act. Our mind thinks in metaphors, those conceptual linkages that connect our neurobiological body with an "explana-

\footnotetext{
35 McFague, Sallie. Models of God: Theology for an Ecological, Nuclear Age. Philadelphia: Fortress Press, 1987, 40-45.

${ }^{36}$ Ibid., 42.

37 See the theory of "emergence" and its correlation with religion. Kauffman, Stuart A. Reinventing the Sacred: A View of Science, Reason, and Religion. NY: Basic Books, 2008.

${ }^{3}$ Gazzaniga, Michael S. Mind Matters: How Mind and Brain Interact to Create our Conscious Lives. Boston: Houghton Mifflin Company, 1988, 230.
} 
tory, motivating, action-driving, framework of meaning." ${ }^{39}$ The linguist George Lakoff and the philosopher Mark Johnson agree that metaphoric thinking arises from lived experience: "Correlations in our everyday experience inevitably lead us to acquire primary metaphors, [which] supply the logic, the imagery, and the qualitative feel of sensorimotor experience to abstract concepts." ${ }^{4_{0}}$ In other words, as McFague argues when she aims to reconceptualize for today a particular theological heritage, metaphor articulates a way to describe the world and how we are embodied in it.

So if we affirm modern sciences' assumption that our mind-and our resulting outlook on life-is shaped by our neurons and genes, then, based on this assumption, our experiences today are not that radically different from those whose experiences are captured in the various scriptures. Neurobiology makes scripture all the more relevant to us because it links our humanity with the humanity of others long before us.

To date, a number of hermeneutical methods have been used to plumb the intended meaning of the author(s) and the author's(s') historical conditioning. Through literary, archeological, historical, social, political, and economic analyses, scriptural scholars have been able to reconstruct the world of former times with a great degree of precision. Psychological instruments have been used as well to enter the minds of those before us. ${ }^{41}$ Neurobiology contributes an additional method to the hermeneutical tool box.

\footnotetext{
39 Jackson, Michael. Things as They Are: New Directions in Phenomenological Anthropology. Bloomington, IN: Indiana University Press, 1996, 31-33.

${ }^{40}$ Lakoff, George and Mark Johnson, Philosophy In the Flesh: The Embodied Mind and Its Challenge to Western Thought. NY: Basic Books, 1999, 128. And on the biological basis of metaphors they say, "There is no mind separate from and independent of the body, nor are there thoughts that have an existence independent of bodies and brains. But our metaphors for mind conflict with what cognitive science has discovered. We conceptualize the mind metaphorically in terms of a container image schema defining a space that is inside the body and separate from it. Via metaphor, the mind is given an inside and an outside. Ideas and concepts are internal, exiting somewhere in the inner space of our minds, while what they refer to are things in the external, physical world. This metaphor is so deeply ingrained that it is hard to think about mind in any other way. Is there a purely literal conception of mind? There is an impoverished, skeletal, literal conception: The mind is what thinks, perceives, believes, reasons, imagines, and wills. But as soon as we try to go beyond this skeletal understanding of mind, as soon as we try to spell out what constitutes thinking, perceiving, and so on, metaphor enters. The metaphors we have cited above, and others that are too numerous to mention here, are necessary for any detailed reasoning about mental acts," 266 .

${ }^{41}$ None of these methods escape the occasional hubris in claiming to 'know' the societies, minds, and motivations of others.
} 
For instance, we know that the evolution of humans has been underway for thousands upon thousands of years. Within the full scope of human evolution, however, our biological and neurological connectedness with our literate-and by this I mean written and aurally literate-ancestors is closer than our connection to their social-political-cultural world. In being closer, it is possible to enter the world of our predecessors as they might have rationally and emotively experienced and understood their world. The embodied approach to scripture means that meaning, its construction and its interpretation, is similar within an order of magnitude between historical periods. Human experiences of pain, anxiety, fear, happiness, and acts of compassion, altruism, and risk taking are going to be neurobiologically similar between us now and them then. If one of the earliest written scriptures we possess, the Rig Veda, of c. 1000 BCE, is but a miniscule fraction in the evolutionary process, it is doubtful the ancient rishis or Brahmin and their followers would be so biologically different from us now..$^{22}$

As such, we need not regard as reductionistic the study of scripture through the lens of neurobiology but see in it a new interpretive tool. Through it we can gain a better sense of our connectivity to and commonality with the scriptural experiences of our predecessors. As we root scripture in lived experience, its authoritativeness for our life rises to the degree that it meets our lived experience today, and is found true, reliable, wise, etc., in short, is consistent with our living in the world and with nature, not because it says, a priori, "thus says the Lord...."

Establishing a neurobiological connection between the body and scripture would seem to suggest that scripture now becomes a book of science. But this is not the case. The connection simply means scripture resonates with our experience and conforms to what it means to live as a human being embedded in nature. Even here we may wonder about the connection. If scripture is said to resonate with our nature, this means we have to see the writers' or prophets' imagination and inspiration as arising, in large part, ${ }^{43}$ from nature, from naturalistic assumptions. We have to admit

${ }^{42}$ Recall Dehaene's claim that our earliest ancestors had the same neural constraints that we do today, and, so, had the same fundamental brain structure that we, who read and write, do.

${ }^{43}$ I say 'in large part' because we can't reduce all of life to material, physical causes. See Stephen Jay Gould's critique of E.O. Wilson's Consilience: The Unity of Knowledge, NY: Alfred A. Knopf, 1998, which does ascribe to this degree of physical reductionism. See Gould, Stephen Jay. The Hedgehog, The Fox, and The Magister's Pox: Mending the Gap Between Science and the Humanities. NY: Harmony Books, 2003, 231. 
that the writers and prophets were not otherworldly in their powers nor were they amanuenses to an outside divine source. Inspiration, imagination, creativity can still arise mysteriously within a naturalistic framework, but only as powers available to all human beings. Some humans are more insightful, intuitive, creative, gifted in the imagination than others, but these people are still regarded as communicating human insights and possessing only human capabilities. ${ }^{44}$

If scripture is taken this way, as within the confines of the human, neurobiological experience, then scripture's authoritativeness shifts to a grounding that is actually more trustworthy, more in keeping with who we are as individuals who grow old, explode in anger, weep for the death of a parent, deliberate between good and bad choices, and agonize over uncertainty. Scripture recounts human beings of a similar neurobiological disposition interpreting and acting out their life in the same material world as ours. Individuals of different cultures and times will interpret their experiences differently. But the biological and neurological mechanisms that lead to these experiences will not be different.

\section{Reading the Body with Reading Scripture}

It was the philosopher Baruch Spinoza $\left(163^{2-77)}\right.$ who laid the groundwork for the naturalistic view of scripture. He recognized, rightly, that scripture will always be with us, and that the religious will draw out of it their particular theological and ethical views. But he wanted to make sure that these views conformed to reason and to nature, and not be based on the premise that they were accountable, ultimately, only to that which lay outside of the human realm, that is, outside of the realm of reason.

${ }^{44}$ That scripture is embodied does not lessen the mystery of inspiration. How inspiration comes is no less fascinating when considered through natural causes, though I realize that in looking for the source of one's inspiration one often comes to a loss of words to explain it; one resorts to appealing to a source external to oneself. No less an atheist as Nietzsche was forced to allow for a sliver of the supernatural to explain it. On how the idea of Zarathustra came to him he said, "Can any one at the end of this nineteenth century possibly have any distinct notion of what poets of a more vigorous period meant by inspiration? If not, I should like to describe it. Provided one has the slightest remnant of superstition left, one can hardly reject completely the idea that one is the mere incarnation, or mouthpiece, or medium of some almighty power." Nietzsche, Friedrich. "Composition of Thus Spake Zarathustra." In The Creative Process. Brewster Ghiselin. NY: Mentor Books, 1952, 202. 
Spinoza helps us reconcile the relevance of scripture with the naturalistic readings of neurobiology.

Educated in Talmudic study in seventeenth century Amsterdam, Spinoza departed from his Talmudic upbringing and questioned the exclusivity of scripture and its theistic underpinning as understood by the Judaic tradition of his day. This questioning got him banned from the synagogue and the Jewish community, leading him to live out his days exiled from the religious communities of his time, belonging to none.

The naturalistic assumptions Spinoza brought to scripture laid the foundation for his advocacy of religious toleration and for keeping religious truth claims from shaping political discourse. Coming of age during the religious battles of the Thirty Years War (1618-1648) and witnessing incidents of brutality against religious non-conformists, he saw early how scripture can be misused. Intolerant political authorities read it selectively to condemn those whom they wished to silence, and theologians used it to support truth claims beyond the scope of reason..$^{45}$ Spinoza regarded scripture as a human document that provided moral guidance..$^{4}$ As a human document, it arose within history, ${ }^{47}$ to be studied as any other historical document. From philology, to archeology, to history, all methodologies come into play to help us construct scripture's historical period and how it was understood by those who wrote and redacted it. More fundamentally, though, to it being a human document, Spinoza said scripture reflected both the thought and substance of the universal "one substance," which, in short form, is nature in all its infiniteness.

If scripture is a human document, how can it be both human and an expression of nature's infiniteness?

Spinoza resolved this paradox by equating the infiniteness of nature with perfect knowledge, the knowledge that comes by pursuing objective reason. Spinoza's naturalism holds that the universe, the natural world, is one substance, possessing two attributes, 'thought' and 'extension.' Says he,

From this it follows most clearly, first that God is unique, that is, that in Nature there is only one substance, and that it is absolutely infinite. It fol-

\footnotetext{
45 Harrisville, Roy A. and Walter Sundberg, The Bible in Modern Culture: Baruch Spinoza to Brevard Childs. Grand Rapids, MI: Wm. B. Eerdmans, 2002, 37f.

${ }^{46}$ Spinoza, Baruch. In A Spinoza Reader: The Ethics and Other Works. Edwin Curley, Ed. Princeton, NY: Princeton University Press, 1994, 30.

47 Popkin, Richard. In The Cambridge Companion to Spinoza. Don Garrett, Ed. NY: Cambridge University Press, 1996, 403. For a fuller treatment on Spinoza's thought of the One Substance, see Rocca, Michael Della. Spinoza. London: Routledge, 2008, 33ff.
} 
lows, second, that an extended thing and a thinking thing, are either attributes of God, or affections of God's attributes. ${ }^{48}$

By 'extension' Spinoza means that the one substance is articulated in matter through the physicality of the universe. Today we speak of the universe expanding from its initial genesis, moving further and further out. Like a balloon, the universe pushes out, but everything is still a portion, an extension, of the initial explosion. Following the metaphor, all finite things are extensions of the one substance. Spinoza regards this infiniteness, this one substance, as God. God, therefore, is articulated in and as all finite things. The infinite extension of the universe is God. Infiniteness is God. ${ }^{49}$ Says Spinoza,

God is one, that is only one substance can be granted in the universe, and that substance is absolutely infinite... Besides God, no substance is granted or can be conceived, that is nothing which is in itself and is conceived through itself. But modes [the finite items themselves] can neither be, nor be conceived without substance; wherefore they can only be in the divine nature, and can only through it be conceived. But substances and modes form the sum total of existence, therefore, without God nothing can be, or be conceived. ${ }^{0^{0}}$

Spinoza does not anthropomorphize God beyond the equation that God is coterminous with the infinite universe: to know nature, through reason, is to know God. ${ }^{1}$

When we turn to the second attribute of the one substance, 'thought,' Spinoza refers 'thought' to the mind of God. The mind of God is the perfection of reason itself, found as we study how the natural world - which includes our human connectedness with nature-works. And God, as the one substance that is the universe, a substance possessing the two attributes of thought and extension, is coequal with these pure ideas. To seek the knowledge of nature's ways ${ }^{52}$ is to possess the knowledge that saves

\footnotetext{
${ }^{8}$ Spinoza, in Curley, Spinoza Reader, 94.

49 Ibid., 85 .

${ }^{5}$ Spinoza, Benedict de. "The Ethics," Part I, Propositions XIV-XV, in On the Improvement of the Understanding, The Ethics, and Correspondence. Trans. R.H.M. Elwes, NY: Dover Publication, 1955 .

${ }^{51}$ Spinoza, in Curley, Spinoza Reader, 88.

${ }^{2}$ While interest in Spinoza has seen a resurgence among naturalists and scientists today, he is not necessarily favored by all. The physicist Richard Feynman was noted for his disdain of philosophy. On one occasion, with his son Michael, they had a condescending laugh about Spinoza, who, said Feynman, had "the most childish reasoning! There were all these Attributes, and Substances, all this meaningless chewing around, and we
} 
us, that lives on, is eternal. As we learn about nature so we learn about God. Naturally, as humans, we are limited at any given time in how much we can know. But the truer our knowledge is to nature's ways, the more eternal is that knowledge..$^{53}$

Reasoning, for Spinoza, is not to reason with the mind alone, as Descartes would have it, but to reason with our emotions, our body, as well. Our emotions anchor our reason. It is our reason, our logic, which ultimately expands or checks and directs our emotions to moral ends..$^{54}$ Michael Gazzaniga, drawing on the research of Antonio and Hanna Damasio, says our emotions kick in first when we make a decision before our conscious mind is even aware of what we are to decide. ${ }^{55}$ As Damasio himself says, emotions are biologically determined, but culture can influence them. ${ }^{5^{6}}$ For instance, the moral philosopher Martha Nussbaum shows that when it comes to formulating laws regarding homosexuality, those arguing against laws that extend rights to gays and lesbians often cite the base emotional response of disgust to denounce homosexuality as unnatural and, therefore, illicit. In response, says Nussbaum, instead of formulating law and policy on a biological impulse, we must draw upon reason and the ethical principles of respect and empathy to decide what is best for society at large and for human flourishing: "The politics of disgust is profoundly at odds with the abstract idea of a society based on the equality of all citizens .... it also violates a fundamental paradigm of political rationality: laws made in response to such animus lack a rational basis. ${ }^{57}$

Turning back to Spinoza, if all finite things, which he termed 'modes,' are expressions of thought and of extension, then conceivably the material text of scripture is an 'extension' of the One Substance and the beliefs and conceptions contained therein are expressions of the 'thought' of the One Substance. In practical terms, this means that to understand scrip-

started to laugh." Feynman, Richard P. The Pleasure of Finding Things Out. Cambridge, MA: Perseus, 1999, 195 .

${ }_{53}$ Spinoza speaks of the eternalness of mind as the perfection of our reason existing beyond the death of the body, which says, in effect, that ideas live on and the truer the idea is to nature's ways, the more eternal the idea is. This notion of trusting in the continuity of an idea, compares to Gamaliel saying, in the New Testament, that if the words of the Apostles Peter and Paul are true, are of God, then their words will live on regardless of how much we try to stop them. If false, then their words will fall flat.

${ }^{54}$ Hampshire, Stuart. Spinoza and Spinozism. NY: Oxford University Press, 2005, xl.

55 Gazzaniga, The Mind's Past, 118-20.

${ }_{56}^{6}$ Damasio, Antonio. The Feeling of What Happens: Body and Emotion in the Making of Consciousness. NY: Harcourt, 1999, 51-52.

${ }^{57}$ Nussbaum, Martha. From Disgust to Humanity: Sexual Orientation and Constitutional Law. NY: Oxford University Press, 2010, xiv. 
ture we must pay attention to the materiality of the text (to the way it was written and redacted and to how flesh and blood human beings would have actually experienced their material world and the implications of what the text says) and to its messages (to what the text is saying to those beyond its time and place). The meaning we are to derive from scripture does not come from elsewhere, separate from the human struggle to live in the world and make sense of it. Nor is meaning derived by placing upon the text philosophies or theologies foreign to it. Rather, it means that since scripture expresses (humanly) inspired wisdom for living in the material world, then whatever meaning we derive from it is to be known and judged through the materiality of its expressions, that is, through its effects. As Spinoza says about scripture, it is not what you say and believe about it that makes it true. It is what you do, what your material, concretized effects, actions, are and what they lead you to which reveals whether what you say is true or not. It is reason plus action that equals truth. For anything can be said, believed, or rationalized. But not everything that is said, believed, or rationalized is translated into deeds fit to live by.

We see, then, that scripture, as both constituted by thought and extension, arises as a product of our mind-body in the natural world. It expresses what many and diverse peoples, mind-bodies, experienced over time. This Spinozian monistic mind-body unity, wherein what is said in scripture is how the natural world is (so miracles against physical laws must be rethought), equates the inspiration found in scripture with 'mind' and the materiality of the written and performed text with the 'body': the scripture that we have before us is an expression of the human mind-body in the natural world. Therefore, in a matter of words, to read the body is to read the text; and to read the text is to read the body. That is, to read our bodies (through available, though imperfect, technological and analytical means) is to read how our bodies read and are reading (when in vivo) the world through which we move; our bodies are a text. And to read a text is to read of stories, of laws, of practices, of people (mind-bodies) who have recorded their experiences, observations, and interpretations of this world.

What this means for our purposes, therefore, is that modern neurobiological readings of the body are not challenges to scripture as much as they are ways to find the scripture in us, in our mind-body. Functional MRIs, PET scans, and CAT scans, the mapping of the genome and of the brain, the depiction in écorchés of the anatomical and functional (physiological) structure of the body, and even tattooing, are all expressions of the infiniteness of thought and of its extension in physicality. These expressions, as a type of scripture, complement the classical scriptures of 
the religions. Like the classical scriptures themselves, they too manifest the one substance and embody, articulate, the mind-body-nature unity. To read the body today is to read scripture, each a complement to and a check on the other, whereby the body complements and checks scripture and scripture complements and checks the body. This back-and-forth exchange functions in the same way in which those engaged in inter-faith discussions expand and moderate their particular views by reading their scriptures in relation to each other, thereby opening to each a different window on the subject.

So where does this leave us? On the one hand, we recognize that reading the body and reading scripture complement each other and inter-relate. Scripture represents the mind-body constructing meaning through the body's physical connection to the material world and by our mind drawing upon prior cultures and writings. And the body is understood by how science and the humanities read it now, influenced by how they have read it in the past. And on the other hand, both the body and scripture remain accountable to their authoritative adjudicators: the body answers to science, based on evidence and experiment, and scripture answers to its religious community with its embodied mythology. Drawing upon Spinoza's one substance monism, then, to read the body and to read scripture are not simply two domains of learning and expression, one scientific and one speculative, one of the senses and one of the imagination. Rather, they are each one aspect of the same reality. They represent two ways to read what it means to live in the material, cosmic world. However much our minds may view and imagine distant universes, we cannot escape the enclosed system that is our universe in all its infiniteness. We cannot get to the other side of it. The mind-body unity we occupy exists and lives within this system. It cannot be and do otherwise. The body we read evolves and articulates itself in relation to this cosmos, which is itself evolving and expanding.

Scripture is no different in its fundamentals. For while it is a record of humans acting out what it means to live in this natural, cosmic world, at its root it is a testimony of mind-bodies expressing their connectivity to the infiniteness of nature, which, à la Spinoza, is God, the ultimate. Be it expressed through ritual, morals, ethics, dogma, institutions, or community, scripture informs each of these.$^{8}$ We read scripture not as a guide to

\footnotetext{
${ }^{5}$ In the case of religions without a scripture in the traditional sense of a written text, what constitutes their "scripture," what is authoritative for them, is found in other ways,
} 
a transcendent deity that is separate from this infiniteness, such that our connectivity to this deity lifts us out of the claims that the natural world has upon us. We read scripture and gain from its instruction, rather, in order to see and learn from human attempts to think and feel in connection to the material world.

I have claimed in this essay that the neurobiological reading of the body challenges if not supplants the reading of scripture, inasmuch as neurobiological assumptions and findings are drawn upon to define how humans are constituted and to determine what they are capable of doing and becoming. As Kwame Appiah puts it in Experiments in Ethics, it is to derive the 'ought' from the 'is.' One only 'ought' to be and become what one 'is' biologically capable of being and becoming. ${ }^{59}$ The immanental nature of our secular age means we evaluate the human from within rather than from without nature, and neuroscience and its biological tangents provide the explanatory mechanics for this 'withinness.'

Scripture is a testament of particular humans living out their connectedness to this natural world and of their relation to others who equally live in this world and express themselves in it. Scripture's authority as a guide toward human flourishing lies in how its stories, precepts, pronouncements, and poetic images, of many groups and people over extended periods and places and neurobiologically linked to the natural world, combine to offer models of and for living in accord with this infinitesimal natural, cosmic world. And the body's authority lies in what it says - through our reading of it - of how our mind-body has fared from our conscious and unconscious attempts to live in accord with these models. As the worlds of thought and of extension are of one cloth, so is the reading of the body and the reading of scripture. We benefit by reading scripture with reading the body and by reading the body with reading scripture.

\footnotetext{
as, for example, in performance, oral narratives, landscape. On the fluidity of scripture, see Olajubu, Oyeronke. "Signifying Scriptures from an African Perspective." In Theorizing Scriptures: New Critical Orientations to a Cultural Phenomenon. Vincent Wimbush, Ed.. New Brunswick, NJ: Rutgers University Press, 2008.

${ }_{59}$ Appiah, Kwame Anthony. Experiments in Ethics. Boston: Harvard University Press, 2008, 21-32.
} 



\title{
DE/CONSTRUCTING TRANSCENDENCE: THE EMERGENCE OF RELIGIOUS BODIES
}

\author{
James W. Haag and Whitney A. Bauman
}

Cogito ergo sum -I think, therefore I am. This infamous Cartesian phrase is one of the most recognized in philosophical history. With it, however, comes one of the most philosophically perplexing issues ever created: what or who exactly is this 'I?' We might choose to focus on the thinking part of who we are. This would increase our attention to characteristics of minds. However, we might choose to focus on our brute existence. This would reduce our attention to characteristics of bodies. Each position, both prevalent in history, is riddled with problems. This chapter is an explicit effort to note the co-existence and co-evolution of bodies and minds because, in some sense, they must necessarily be held together.

The task we have set for this chapter is to assess how one particular product of human minds-religion-relates to bodies. There are two streams of information that must be accounted for and maintained if this association is possible - the first stream of information moves downward emphasizing our dependence and connectedness with the world; the second stream of information moves upward stressing the need for phenomenological explanations of reality. Too often one of these streams is jettisoned for the other. On the one hand, reductive materialism wants to do away with the ontological reality of the immaterial, including thoughts, imagination, self-consciousness, religion, etc. On the other hand, idealism works to undermine the ontological reality of the material world. In an effort to move beyond this false dualism, thinkers such as Spinoza espouse monism and many ecologically minded people espouse some type of holism. It is our contention that monism and holism deny the full reality of both sides of the mind/body or spirit/matter dualism. Instead we develop here an emergent option that gives full reality to both sides of the coin while overcoming the very dualism that sets up the split between them.

First, there needs to be a concerted effort to avoid dualisms and the inevitable favoritism that this creates. Within philosophy of science and constructive post-modern philosophy, efforts to move beyond the dualism of mind/body, nature/culture are well underway. Here, we especially 
examine French philosophers Gilles Deleuze and Felix Guattari's understanding of the 'plane of immanence' and 'assemblages,' in which nature and culture, humans and technology, no longer find themselves at dueling ends of the spectrum. Deleuze and Guattari provide a schema in which human becoming is not an evolution away from the rest of nature, but a progressive movement toward the proliferation of possibilities for future becoming. We argue that individual and collective human bodies become the site(s) at which religious thought matters to the rest of the natural world.

Second, the science of emergence, as particularly developed by anthropologist and neuroscientist Terrence Deacon, provides an approach that avoids the 'greedy reductionism' prevalent in science today. Deacon demonstrates how those processes that provide the framework for dealing with such human dilemmas as intention, desire, meaning, morality, and even religion are physical processes and yet more than physics alonea direct challenge to the rampant acceptance of reductionistic schemas in our modern ethos. We believe emergence theory supplies the needed background for preserving the validity of a subject like 'religion and the body.' Emergence allows us to both embrace the physical instantiation of human beings (i.e. our bodies) as described in physics and biology while also embracing the power of experiences understood as religious (i.e. our minds).

These two sources of information about 'religious bodies' may at first seem like bricolage. However, both of these distinct philosophical methods/approaches have common roots in a lineage that has drawn explanatory focus away from the vertical transcendent to the horizontal immanent. Both emergence theory and Deleuze and Guattari's seemingly ironic 'transcendental empirical' approach, draw from the intellectual history of 'event' based thinking (e.g., Heraclitus, Bateson, and process thought) and metaphysics of immanence (e.g., Spinoza, Henri Bergson). Despite this shared ancestry, there is little work that brings the two streams of thought together in dialogue and virtually none around the topic of how religions matter bodies. The 'mattering of bodies' trope used throughout this paper is used to connote the idea that religions don't just matter in some sort of experiential, faith-based, or intellectual way to those who adhere to religious beliefs and doctrines; rather, religions also shape bodies in the world around us through the ways their institutions, rituals, and beliefs materialize. We believe these two paths could prove promising and ethically relevant when examining how religious or meaning-making practices shape bodies in the world. 


\section{World's Mattering}

The meaning-making practices of the globalizing western 'tradition' have carefully removed human, among other, bodies from the biological and ecological processes of the world. Consider for yourself what comes to mind when you reflect on the meaning of the word 'nature.' Our guess is things such as rivers, trees, mountains, and bears were more prevalent in your mind than cities, people, or technology. How have our meaningmaking practices relocated certain bodies outside of our descriptions of nature and equally as important, how have they also identified certain bodies exclusively within nature? Any focus on 'the body' ought to explore the ways in which meaning-making practices matter (in and to) bodies. Precisely because most meaning-making processes construct an inside/ outside description of nature that results in a valuational dichotomy between the transcendent and the immanent, the human is theoretically dis-embodied from the rest of the natural world. ${ }^{.}$This theoretical disembodiment, what one might call a transcendent anthropology, (or what others, including Terrence Deacon, would call the 'ghost in the machine') is precisely what we believe has been confused with a literal disembodiment. The unfortunate result is that this dualistic separation has destructive consequences for many earthly bodies. A large body of literature explores how this colonizing type of dualistic transcendence mimics the Omni-Christian God in whose image, according to Abrahamic traditions, humanity is created. ${ }^{2}$ Much feminist and ecofeminist literature explores this type of dualistic thinking in the form of patriarchy, which puts men

\footnotetext{
${ }^{1}$ It is impossible to think about 'embodiment' without acknowledging the importance of the feminist critiques of patriarchy and how this ideology materializes in ways that are detrimental to many bodies. The scholarship in critical theories and liberation theologies is assumed as the context from which this whole topic can be addressed. Though not mentioned, this paper is a partial continuation of these types of concerns.

${ }^{2}$ Though we focus on the Abrahamic faiths here, in Buddhist and Hindu traditions, humanity's final goal is also transcendent-release from samsara, the cycle of birth and death, which is the realm of suffering. Further, for the most part there has been a hierarchy in that release through attaining enlightenment is only possible for human beings (other life forms must first be reincarnated as human in order to attain enlightenment). The exception to human exceptionalism in religious traditions can be found in many indigenous traditions. Their 'religion' is more accurately a lifeway that is tied to particular places and landscapes. Given this, the destruction of indigenous peoples' communities through deforestation, damming rivers, or removal and placement on reservations becomes an instance of how a transcendent understanding of humans dis-embodies other peoples and places.
} 
as closer to reason/culture and thereby dominant over women who are closer to emotion/nature.

Given this critique of a transcendent anthropology, some have assumed the remedy is complete immersion into or identification with the rest of the natural world - a type of reductionistic or eliminative approach. This is exemplified in some forms of Deep Ecology as captured by Aldo Leopold's famous quip: "think like a mountain." ${ }^{3}$ However, this equal and opposite reaction to transcendent anthropology erases the difference of bodies in an attempt to conceptualize one holistic Body of which we are all a part. This form of holism (when materialized) can be just as colonizing as a transcendent anthropology. ${ }^{4}$ Ironically, though many claim these positions to be at mutually exclusive ends of a metaphysical or ontological spectrum (immanent/pantheist/monist::transcendant/deist/ dualist, respectively) they both end up denying the evolving, planetary contexts of bodies. Holism tends to erase the important differences of evolving bodies in favor of identification. A transcendent anthropology erases difference through assuming a common humanity over and against the rest of the natural world, and working to assimilate differences into its own image. Luckily many scholars are beginning to articulate ways out of this holism-dualism trap. ${ }^{5}$ Here we will discuss how pure immanence, assemblages, and becoming, as developed by Deleuze and Guattari, aide us in thinking about how meaning-making practices emerge from and return to effect planetary bodies.

\section{Mattering Bodies that Matter}

There is more than one way to re-think ourselves into the rest of the natural world in a way that avoids both holism and reductionism. Here we

3 Leopold, Aldo. Sand County Almanac. Oxford, UK: Oxford University Press, 1949.

${ }^{4}$ See, e.g. Michael Zimmerman's work on Deep Ecology and Nazism: Zimmerman, Michael. Contesting Earth's Future: Radical Ecology and Postmodernity. Berkeley, CA: University of California Press, 1994.

5 The phrase 'line of flight' is from Deleuze, Gilles and Felix Guattari, A Thousand Plateaus: Capitalism and Schizophrenia (Minneapolis, MN: University of Minnesota Press, 1987): $3-25$. Other than the scholars we mention in this paper, many others are making strides toward some type of 'emergent' perspective or radically immanent (but not holistic) perspective. These include, for example: Latour, Bruno. The Politics of Nature: How to bring the Sciences into Democracy (Cambridge, MA: Harvard University Press, 2004); Haraway, Donna. Simians, Cyborgs and Women: The Reinvention of Nature. New York: Routledge, 1991; Kaufman, Gordon. God The Problem. Cambridge, MA: Harvard University Press, 1972; Nancy, Jean Luc. The Dis-enclosure of Christianity. New York, NY: Fordham, 2008. 
offer a particular set of metaphors from the works of Deleuze and Guattari in hopes that they will be persuasive ways of thinking about 'Bodies that Matter.' Of course 'matter' here is used in the two-fold way Judith Butler uses it: "to know the significance of something is to know how and why it matters, where 'to matter' means at once 'to materialize' and 'to mean.' " As such, 'mattering' is directly connected with 'meaning-making,' which we take to be a central feature of all religions (re-ligare/legere-to re-read, bind back). Thus, we take the meaning-making project to be a necessary feature of what it means to be human being and human becoming. This results in the important process through which we make our own bodies and others matter in both constructive and destructive ways.

Heidegger understood well the way in which our practices of meaning-making, or 'enframement,' are sources of both destruction and creation. ${ }^{7}$ For Heidegger, Enframing, which we are calling meaning-making, has the power to block poesis or the 'bringing forth' of new life, but it is also something which we cannot live without and is in fact the source of possibilities for the future-becoming of earth-bodies in a more ecologically sound and socially just way. ${ }^{8}$ The problem arises when we fail to see our own enframing (such as a transcendent anthropology) as just that: one way/lens/worldview/possibility. When we take an enframing as the Enframement, such as the light of Reason, we turn life into 'standing reserve,' or things which become mere commodity for that particular Enframement. ${ }^{9}$ If we understand 'enframing' broadly as meaning making

\footnotetext{
${ }^{6}$ Butler, Judith. Bodies that Matter: On the Discursive Limits of Sex. New York: Routledge, 1992, 32 .

7 Heidegger, Martin. The Question Concerning Technology. New York, NY: Garland, 1977, 33: He writes, "On the one hand, Enframing challenges forth into the frenziedness of ordering that blocks every view into the coming-to-pass of revealing and so radically endangers the relation to the essence of truth. On the other hand, Enframing comes to pass for its part in the granting that lets man endure-as yet unexperienced, but perhaps more experienced in the future - that he may be the one who is needed and used for the safekeeping of the coming to presence of truth. Thus does the arising of the saving power appear."

${ }^{8}$ Lest someone accuse us of being anthropocentric, we are not saying that humans hold all the power to save the world. On the other hand, we are not misanthropic or nihilist enough to assume a future world without humans. Some deep ecologists and environmentalists suggest that the earth will be much better without us (and with warrant). However, as a part of nature, human beings increase the diversity of the ongoing process. What we add is no less valuable. In fact, value judgments, making-meaning, may be what is lost from the rest of the natural world without human beings. So, my assumption here is that meaning-making practices of humans can and ought to add to the value of the ongoing process and not that human beings are exceptional because of this quality.

9 Heidegger, The Question Concerning Technology, 19.
} 
practices-including 'world religions,' 'free-market capitalism' and even environmentalism that feeds on a romantic understanding of naturethen we have many examples of how a particular enframement taken to be the Enframement makes commodities out of bodies..$^{10}$ These enframements force life into very particular bodies, such as: plant, animal and mineral resources; pristine wilderness vs. urban; civilized and barbarian; racial categories; rich and poor; master/leader and slave/citizen; male/female, etc. In other words, it is important to analyze exactly how our enframements are shaping and affecting the bodies of the world around us.

Deleuze and Guattari address the problems with enframement with their metaphysic of 'pure immanence.' Whereas Heidegger, despite his best efforts to get away from onto-theology, perpetually sought a more 'authentic' enframement of transcendent being, whether it be the receding horizon that we move toward or a better connection with the ground of being, Deleuze and Guattari transform being into a becoming plane of pure immanence. Deleuze and Guattari write, "Immanence is immanent only to itself and consequently captures everything, absorbs All-One, and leaves nothing remaining to which it could be immanent." ${ }^{\text {"11 }}$ Thus, everything, including ideas, matter, and spirit exist within an emergent reality and not in a pure objective space that is outside, above, or beyond the world. This means that all human meaning-making tasks are never done from a separate 'smooth space' or unbiased position, but always occur radically within our contextual and embodied existence. This implies that the distinctions made between nature and culture, body and mind, humans and nature, while perhaps helpful are, in the end, illusory.

This does not imply a holistic worldview of the sort found in Deep Ecology, but rather an immanent milieu meaning that the plane of immanence (i.e. all of reality) is multi-layered, textured, and contains 'a thousand plateaus.' Simply put, the plane of immanence is the eternal return or proliferation of difference. ${ }^{12}$ By the 'eternal return of difference' Deleuze and Guattari simply want to connote that the moment-by-moment nature of the ongoing process of life is not a reinforcement of what has come before, but rather involves at each moment the return and proliferation

\footnotetext{
${ }^{10}$ See Morton, Timothy. Ecology Without Nature: Rethinking Environmental Aesthetics. Cambridge, MA: University of Harvard Press, 2008.

${ }^{11}$ Deleuze and Guattari, What is Philosophy (New York, NY: Columbia University Press, 1994), 45 .

${ }_{12}$ Gilles Deleuze, Difference and Repetition. New York, NY: Columbia University Press, 1994.
} 
of differences. There is no single perspective that captures 'the whole,' but rather the plane of immanence is multi-perspectival and always increasing in perspectives. From this recognition of multi-perspectivalism, even transcendent concepts (i.e. transcendent anthropology) are rethought as one perspective on reality and thereby disallowed to recapitulate all of reality in their own image as absolute enframements. ${ }^{13}$ Because there is no space outside of the plane from which to draw all life in or judge all life by, ideas of transcendence become subject to the effects of their return to the multiple bodies that make up the plane of immanence. Put another way, a concept (transcendent or not) will be judged more by its ethical effects upon bodies rather than its correspondence to some sort of Reality. Our questions about anthropology or embodiment move from what is 'objectively true' or 'real,' to an analysis of the effects on the future becoming of life.

As a perpetual proliferation of differences, the plane of immanence is not closed but is in infinite movement. "It is the horizon itself that is in movement: the relative horizon recedes when the subject advances, but on the plane of immanence we are always and already on the absolute horizon. ${ }^{14}$ In other words, there is no outside point toward which things move, there is no ever-receding horizon toward which we advance in some prepared teleological way; rather, we are already always on the horizon, located within the plane, moving and looking back toward the plane of immanence, creating 'folds' in the plane, and assembling bodies all along the way. ${ }^{15}$ Conceptually, our knowledge embodies that lifeworld that we know, and our knowledge matters bodies through this filter. Confusing any given current horizon with an ultimate stable horizon, then, colonizes bodies and reduces possibilities for becoming. From this perspective, we do not fall into the holistic idea that we are 'one with the universe,' but rather, each subject takes account of the whole from a located and limited perspective. Perspectivism here is "not the variation of truth according to

\footnotetext{
${ }^{13}$ This is also the problem with Enlightenment / Reason that Horkheimer and Adorno identify in their infamous Dialectic of the Enlightenment.

${ }^{14}$ Deleuze and Guattari, What is Philosophy?, 38.

${ }_{15}$ Catherine Keller speaks of this as the 'origami-like' nature of reality: “The event conjures a world of fireworks, the fold explicates an origami universe. The event intensifies novelty in explosion, orgasm, revolution; the fold, precisely translated as prehension, suggests connectivity, drapes, waves, intertwinings." From: Keller, Catherine. "Complicities: Folding the Event in Whitehead and Deleuze" a paper delivered at Event and Decision: Ontology and Politics in Badiou, Deleuze, and Whitehead (Claremont, CA December 7 , 2007) manuscript page 2.
} 
the subject, but the condition in which the truth of variation appears to the subject. ${ }^{116}$ It is the folding together of the world from multiple perspectives that perpetuates the proliferation of differences in the plane of immanence and that perpetuates the forming of diverse bodies or assemblages.

For Deleuze and Guattari, bodies are diverse assemblages that make up the plane of immanence. As such, we live in a multi-perspectival embodied reality. "We can never have knowledge of nature as a whole. Divine power is manifest in its diverse parts (places, species, lands, and waters); each self is not identical to any other; and every body comprising the world consists of diverse matter. ${ }^{{ }^{\prime 7}}$ In fact, our unique subjectivities and identities are formed in response to the assemblages of histories, cultures, and institutions into which we are born, and return to affect these things. These assemblages act as sieves that filter reality and shape bodies into certain identities. Thus, that which is excluded or filtered out from our identities is just as, if not more, important in identity formation. To follow the Aristotelian understanding of 'like seeks like' in identity formation would then, negate that which is other in the process of assimilation and thereby negate that which is part of one's own identity: that which gets left out. One could also think of an assemblage as an ecosystem of which we are just a part, or the planetary assemblage that has been emerging since the 1960 os environmental movement. ${ }^{18}$

Assemblages, then, challenge the conceptual cutting of one body from another, of humans from the rest of the natural world, of technology from nature, etc. The assemblage always places any particular moment of embodiment in question. From this understanding we can side with Donna Haraway and claim that we are both Cyborgs and Companion Species. ${ }^{19}$ Our bodies, like the sum of the bodies that make up the planetary, are in process, becoming, and never merely a noun. What does it mean to be human in this becoming of assemblages? It means at least re-thinking

\footnotetext{
${ }^{16}$ Deleuze, Gilles. The Fold: Leibniz and the Baroque. Minneapolis, MN: University of Minnesota Press, 1993, 20.

${ }^{17}$ Olkowski, Dorothea. "Political Science and the Culture of Extinction," in Deleuze, Guattari, Ecology, edited by Bernd Herzogenrath. New York: Palgrave Macmillan, 2009, 153.

${ }_{18}$ The idea of Gaia set forth by James Lovelock is a newly emergent assemblage that could help us 'deterritorialize' our previously held notions of subjectivity and embodiment and 'reterritorialize' into becoming planetary bodies. See Lovelock, James. Gaia: A New Look at Life on Earth. Oxford, UK: Oxford University Press, 1979.

19 Haraway, Donna. Simians, Cyborgs and Women and When Species Meet (PostHumanities). Minneapolis, MN: University of Minnesota Press, 2008.
} 
ourselves with other earth bodies. ${ }^{20}$ In particular, Deleuze and Guattari highlight what becoming animal, plant and mineral might mean.

In speaking of contemplating animals, plants and minerals, they write, "These are not Ideas that we contemplate through concepts but the elements of matter that we contemplate through sensation. The plant contemplates by contracting the elements from which it originates-light, carbon, and the salts - and it fills itself with colors and odors that in each case qualify its variety, its composition: it is sensation in itself." ${ }^{21}$ It is the same sensorial way in which the human subject works. Subjectivity is nothing more than the assembled ongoing experience of different things giving rise to contemplation. Plants, minerals, animals, and humans are all various contemplations on the continuous flow of life. In order to open up further possibilities for the future, human beings can enter hybrid relationships with other life, in hopes of creating 'lines of flight' for future possible becomings. "The human becomes more than itself, or expands to its highest power, not by affirming its humanity, nor by returning to animal state, but by becoming-hybrid with what is not itself. This creates 'lines of flight'; from life itself we imagine all the becomings of life, using the human power of imagination to overcome the human." ${ }^{22}$ Becominghybrid is the acceptance of the inexhaustible complexity of the world and the recognition that new possibilities for becoming grow directly through multiplication of these new assemblages. In other words, this is not the holistic 'think like a mountain' of deep ecology, but rather an affirmation and proliferation of the differences of the ever-evolving flow of life. Again, what Haraway might describe as our cyborg ontology. In such an ontology, difference is primary and the support of bio-diversity in the becoming planetary community is central to the accounting for the inevitable processes of life.

From within this evolving planetary community, we would argue that meaning-making practices are no longer about transcendent spaces from which to order all bodies, but rather about the making of future possibilities toward something that is 'not yet.' ${ }^{23}$ In other words, this metaphysics

\footnotetext{
${ }^{20}$ Mazis, Glen. Earthbodies: Rediscovering Our Planetary Senses. Albany, NY: SUNY Press, 2002.

${ }^{21}$ Deleuze and Guattari, What is Philosophy?, 212.

${ }^{22}$ Colebrook, Claire. Gilles Deleuze. New York: Routledge, 2002, 129.

${ }_{33}$ Though Deleuze and Guattari had a bit of an allergy to religion, they drew from such thinkers as Bergson, Spinoza, and Whitehead. These figures are also drawn on by Religionists, not to mention emergent theorists who never seem to draw from Deleuze and Guattari.
} 
of immanence or 'transcendental empiricism' (not to be confused with transcendence) as Deleuze and Guattari might claim, provides a method for rethinking what 'human' means in terms of planetary becoming. ${ }^{24}$ The term 'transcendental empiricism' simply suggests that ideas of 'transcendence' actually negate the possibility of transcendence by claiming an objective space that is closed off (e.g. we have the material reality and the transcendent Reality). Thus, for Deleuze and Guattari, the only form of transcendence that actually allows for transcendence is recognition of the unique perspectives within the multi-perspectival plane of immanence: where the future is open and what is 'transcendent' are the various unique points of being-becoming or assemblages. It is from this space that new possibilities for becoming can emerge, rather than the mere recapitulation of all reality under a single, transcendent concept. Theirs is an understanding of reality that is always 'on the move' and multiperspectival. Such an understanding requires a re-thinking of the function of meaning-making practices as well, away from transcendent sources of comfort and toward making meaning out of our multi-perspectival, evolving realities.

In Crossing and Dwelling, Thomas Tweed sets out to develop such a theory of religion based on dynamics and flows. He writes, "Theory as embodied travel is not a stationary view of static terrain ... It is more like 'dynography'." 25 This resonates well with Deleuze and Guattari's notion of embodiment as becoming assemblages. In other words, the focus on the body' becomes a focus on the various exchanges between peoples, the rest of the natural world, etc. A 'body' as noun is more like a snapshot of the becoming body rather than any sort of foundation for establishing an essential self. Religion, too, emerging from histories of interacting bodies is thus also always something in motion. Tweed writes, "Religions are confluences of organic-cultural flows that intensify joy and confront suffering by drawing on human and suprahuman forces to make homes and cross boundaries. ${ }^{26}$ This definition deserves a bit of parsing.

${ }^{24}$ There are many similarities with the 'becoming' of Deleuze and Guattari and that of Whitehead. Indeed they draw from Whitehead quite often in their works. However, they are opposed to the panentheism which suggests some holding onto transcendence in the form of (at least) possibilities that are already contained in the primordial nature of God. Possibilities for Deleuze and Guattari are emergent rather than selected and/or directed in some way.

${ }^{25}$ Tweed, Thomas A. Crossing and Dwelling: A Theory of Religion. Cambridge: Harvard University Press, 2006, 11.

${ }_{26}$ Ibid., 54 . 
By identifying religions as confluences and flows, Tweed highlights the way that meaning-making practices take place and shape bodies over time. He writes, "spatial metaphors (dwelling and crossing) signal that religion is about finding a place and moving across space, and aquatic metaphors (confluences and flow) signal that religions are not reified substances but complex processes." ${ }^{27}$ Thus, as Latour has also commented, religions are about focusing in on the here and now rather than an escape to some far off transcendent space. This understanding of religion focuses on how religions contribute to any given assemblage (body, landscape, ecosystem, society) and also draws attention to possible 'lines of flight' toward new ways of becoming. Religion, then is partially about transgressing current boundaries or current manifestations of assemblages. Tweed's understanding of religion "invites scholars to attend to the multiple ways that religious flows have left traces, transforming people and places, the social arena, and the natural terrain. ${ }^{28}$ However, meaning-making practices are also about creating dwellings.

A dwelling is "always 'for a time'; it is never permanent or complete," it is not static but also a doing. ${ }^{29}$ Much like the move from transcendent foundations to grounds, so here we find a move from identifying with a substantive place to that of a more nomadic understanding of identity and home. Bodies, places, and other assemblages are on the move. As such, when our meaning-making practices serve to reify a given moment, we are cut off from this continual flow for a time and often try to stem the flow into a reified structure. This is descriptive of the process of colonization and violence whereby all bodies and all life are forced into one way of being-becoming in the world. This reifying process, as so many critical and liberation discourses have argued, is violent and even deadly for a huge number of planetary bodies. Rather than understanding ones own bodily perspective as a foundation, we may better understand our own bodily identities as a point of departure. "Religiously formed bodies, which are simultaneously organic, domestic, communal, and cosmic spaces, function as the initial watch and compass." ${ }^{30}$ From this understanding, our bodily assemblages become points from which our journey is experienced, but not closed off to the future becoming of our own and 'other' identities. As Deleuze and Guattari note, this understanding recognizes that becoming

${ }^{27}$ Ibid., 59 .

28 Ibid., 62.

29 Ibid., 81.

$3^{\circ}$ Ibid., 103 . 
multi-perspectivalism is the reality that we all, always and already, find ourselves in.

Given this dynamic understanding of meaning-making practices, religion becomes not so much a place where bodies are bound to transcendent ideals, but a source where becoming bodies draw navigational information from amidst the continual flow of life. Without origin or telos, becoming bodies are better understood as assemblages of the human, plant, animal, mineral, cultural, and technological flows around them (as contemplations of life in the words of Deleuze and Guattari). The future of life is then open and emergent.

\section{Emergence}

Our effort thus far has been to claim that dualistic separations are problematic precisely because absolute metaphysical cuts are not simply dangerous, but impossible. We have challenged limited (including dualistic, holistic, and eliminative) conceptions of 'nature' as myopic. As cyborgs, human characteristics are an unusual melding of concepts oftentimes left separated. Perhaps the most crucial of these, as we have noted, is the dualistic split between body and mind. Mind can influence matter and vice versa despite their radical differences in causal architecture. However, this neither implies that mind is just matter nor that matter is just a construction of the mind. By beginning as we have, it might appear that we are committing the very error that we denounce. After all, by developing the ideas of Deleuze and Guattari, we have accounted for that stream of information most appropriately called representational. Have we not also assumed a split between the representational and the physical? Between matter and mattering? We have certainly noted a difference, but we believe this difference is heuristic, not metaphysical.

In order to support this claim, we must now account for another stream of information that can best be called physical. Assemblages and enframements are central in our meaning-making process, but the meaning-makers themselves are physical, chemical, and biological bodies. Remove that significant piece of meat housed within human skulls and assemblages or enframements disappear. This is not to say, however, that the only interesting information in the world can be reduced to neurochemical interactions. Stated philosophically, we would say that human brains - with their spectacular symbolic capacities-are necessary, but not sufficient in accounting for meaning-making constructions. It is our 
contention that these processes-and with them, religious experiences, traditions, and practices-are emergent features of the cosmos.

We should note that over the last few decades, important advancements in the natural sciences have led to a surplus of proposals on how to scientifically account for the phenomena of religion. No longer are the descriptive anthropological or sociological theories of religion the norm in the scientific community; in their place, new science-based tactics offer explanative theories that address the origin and persistence of religion in human societies. Unfortunately, many of these new approaches attempt to 'explain away' religion as the result of more basic and fundamental mechanisms. This eliminative type of reductionism captures the basis of the most prominent science-based theories of religion currently produced. Consider Pascal Boyer's argument that religion is purposeless today because it is the accidental consequence of non-religious adaptations that occurred in our ancestors thousands of years ago. ${ }^{31}$ Or, David Sloan Wilson's argument that religion is merely a functional adaptation that somehow provides a type of advantage over our competitors. ${ }^{32}$ Or, Richard Dawkins' theory that religion is a cultural artifact (a meme) that persists like a parasite infecting the minds of its hosts. ${ }^{33}$ The problem with these options is that they fail-because of their 'eliminative reductive' stance-to account for any intrinsic value or meaning present in religious traditions. It is our contention that a scientific approach need not be greedily reductionistic.

Our alternative path is to follow a science of emergence. So, what is emergence? About two millennia ago, Aristotle unwittingly came up with the slogan now oftentimes associated with emergence: "The whole is something over and above its parts and not just the sum of them." ${ }^{34}$ What does this mean? Consider an automobile. There are many parts that make up a car (i.e. spark plugs, doors, wheels, etc.), but we cannot simply dump all of these parts on the floor and claim we have a car. There must be some type of special organization of the parts in order for the final product to qualify as a car. This is a very generic example of the logic Aristotle was

\footnotetext{
${ }^{31}$ See Boyer, Pascal. Religion Explained: The Human Instincts That Fashion Gods, Spirits and Ancestors. London: Vintage, 2002.

$3^{2}$ See Dawkins, Richard. Darwin's Cathedral: Evolution, Religion, and the Nature of Society. Chicago: University of Chicago Press, 2002.

33 Dawkins, Richard. The God Delusion. London: Bantam Press, 2006.

${ }_{34}$ Aristotle, The Metaphysics in The Complete Works of Aristotle, 2 vols., Jonathan Barnes, ed. Princeton, NJ: Princeton University Press, 1998, Book VIII, Part 6.
} 
employing in his parts/whole statement-you cannot simply add parts together and get the whole. Now, apply this logic to the natural world and the complexity and possibilities explode. With the car, the organization needed to fit the parts together is imposed from the outside by a factory worker or mechanic. In nature, the organization arises (emerges) spontaneously; it self-organizes. One might say our current problem is that we are attempting to apply mechanical explanations (how a car gets put together) to organism explanations (how a cell develops). Deacon poignantly states: "Organisms are not built or assembled." ${ }^{35}$ Emergence is slowly shifting how we think about these issues.

To follow this out, consider the ideas running through your head right now. Our ideas are probably the most intimate aspects of who each of us is; they help make up our personal identity. Where do the ideas come from? We might describe features of our childhood, moments in a college classroom, or deep discussions with colleagues. While this may appear to be the case from our perspective, modern science and philosophy counters these commonsensical explanations. Why? Built into the Western conception of science is a very old and powerful assumption: reality is to be found in the simplest parts. In other words, look to the most basic level-both spatially (the smallest bits) and temporally (the original cause) - and you will find the 'really real' of the world. Philosopher Owen Flanagan refers to this approach as "smallism." ${ }^{36}$ So, where do the ideas in your mind come from? It depends on where you find the smallest and significant parts — options on the table include neurons, ${ }^{37}$ genes,${ }^{38}$ and quantum information. ${ }^{39}$ If this assumption shades our interpretations, then it will be easy to abandon the phenomena of wholes because the parts will be viewed as more fundamental and thus more important. The prime difficulty with this position is that it eliminates many of the world's features most consider to be valuable and important, but also genuinely real (i.e. consciousness, religion, ethics, etc.).

\footnotetext{
35 Deacon, Terrence. "Emergence: The Hole at the Wheel's Hub," in The Re-Emergence of Emergence: The Emergentist Hypothesis from Science to Religion, eds. Philip Clayton and Paul Davie. New York: Oxford University Press, 115.

${ }^{36}$ Flanagan, Owen. The Problem of the Soul: Two Visions of Mind and How to Reconcile Them. New York: Basic Books, 2002, 216-217.

${ }^{37}$ Churchland, Paul M. The Engine of Reason, the Seat of the Soul. Cambridge, MA: MIT Press, 1999.

${ }^{38}$ Dawkins, Richard. The Selfish Gene. Oxford: Oxford University Press, 1976.

39 Walker, Evan Harris. The Physics of Consciousness: Quantum Minds and the Meaning of Life. New York: Perseus Books, 2000.
} 
Emergence is a direct challenge to the eliminative reductive view prominent today. It is certainly not the first, but it comes with powerful explanatory tools (i.e. systems theory, complexity theory, non-equilibrium thermodynamics, etc.). The challenge is steep because the very connection between parts and wholes must be explained, not simply assumed. ${ }^{40}$

With Terrence Deacon, we have a theory of emergence that allows for this very task. Consider language as an example. In his book, The Symbolic Species, ${ }^{41}$ Deacon argues that language use is not the result of greater intelligence or the appearance of a special mental faculty; instead, there is a fundamental transition in human brains from our primate relatives-it is the transition to symbol use. In the stages of human evolution, the capacity to represent complex, abstract systems of meaning and their internal relationships signifies a crucial change. It is not about a new addition to the brain. As Deacon articulates: "Language processing is ultimately carried out with the same brain structures and functional logic that other primates use for nonlinguistic functions." ${ }^{42}$ By postulating a type of coevolutionary connection between language and the brain, Deacon points to the considerable parallel constraints operating on both phenomena. Human cultural environments have exerted strong selective pressure on brain evolution.

In this unique co-evolutionary process, we should expect that human brains and language would begin to 'fit' with the unique processing constraints of human communication. Modification of the environment can lead to a type of 'evolutionary short circuit' — altering our 'niche' can lead to artificial selection. For example, as beavers build dams they create an aquatic environment that would not have appeared 'naturally' or without their involvement. Beavers' bodies, with their aquatic features, reflect this new situation; that is, by altering their environment, beavers have influenced selective pressures. For Deacon, language is analogous: "Extensive

$4^{4}$ This description of emergence (and this is merely a first step in understanding the logic) is necessarily basic and brief. For further information, see Clayton, Philip and Paul Davies, eds., The Re-Emergence of Emergence: The Emergentist Hypothesis from Science to Religion. New York: Oxford University Press, 2006; JKim, Jaegwon. "Emergence: Core Ideas and Issues," Synthese, vol. 151, no. 3 (2006): 547-559; O'Connor, Timothy and Yu Hong Wong, "The Metaphysics of Emergence," Noûs 39 (2005): 659-679.

${ }^{41}$ Deacon, Terrence. The Symbolic Species: The Co-evolution of Language and the Brain. New York: W.W. Norton \& Company, 1997.

${ }_{42}$ Deacon, Terrence. "Language as an Emergent Function: Some Radical Neurological and Evolutionary Implications," in Religious Narrative, Cognition, and Culture: Image and Word in the Mind of Narrative, eds. A.W. Geertz and J.S. Jensen. London: Equinox Publishing, 2007. 
use of symbolic communication would have constituted something analogous to a novel niche, imposing novel selection pressures on human cognition and vocal systems." ${ }^{43}$ On an evolutionary timescale, symbols eventually provide the survival advantage that eventually biases humans to make virtual meaning connections. The result is that we have evolved in a world unlike any other environment; a type of double-world in which both the mental and physical co-evolve leading to what Deacon calls 'a whole new phylum of animals.'

The world is composed of rocks and trees, but the human world is more than tectonic and organic processes. Symbolic entities-such as institutions, rules, or values-are as real as the rocks and trees around us and help us frame our worldview. What we are most interested in assessing in this paper are moments of religious experience (i.e. phenomena such as awe, a sense of dependence, reverence, and even mystical experiences). We argue that this category of experiences are the direct consequence of human symbolic abilities and can most appropriately be termed emergent experiences. To articulate this, Deacon asserts that these experiences "emerge out of the unique capacity of symbolization to imagine the juxtaposition and fusion of ideas and experiences outside of normal experience and, in the process, to induce otherwise mutually exclusive emotions to become simultaneously experienced." ${ }^{\prime 4}$ What we can take from this is the powerful connection between physical processes and representational phenomenon, what Deleuze and Guattari term assemblages.

These experiences are not somehow in the world simply waiting for our discovery; rather, our ability to form complex symbolic networks is an emergent capacity with a complex co-evolutionary history involving both biological and social evolutionary processes-it is what we have been referring to as the meaning-making process. Not only is this significant for the evolution of enlargement in the human prefrontal cortex, but also the origin of meaning must ultimately be traced to relationships and dynamics that cannot be simply identified with biological substrates. What this means is that meaning itself is an evolutionary emergent feature of the universe. Our ideas thus have a 'life of their own' and become deeply entangled in the physical contexts that in turn reshape other ideas in radical ways. The result is that we spend much of our waking lives in what

\footnotetext{
43 Ibid.

${ }^{44}$ Deacon, Terrence and Tyrone Cashman, "The Role of Symbolic Capacity in the Origins of Religion," Journal for the Study of Religion, Nature and Culture, Vol. 3, No. 4 (2009).
} 
amounts to a virtual reality of imagined conversations, possible futures, and past occurrences. This is the origin of the cognitive processes involved in religious experience. Deacon writes, "Because emotional experiences are dynamical neurological processes, the 'blended' interactions among two or more emotional processes that would normally be mutually exclusive results in something quite different from merely a little of one and a little of the other. The result is a uniquely unprecedented synergy." 45 Just as Aristotle claimed, "The whole is something over and above its parts and not just the sum of them," so we too follow this logic in contending that religious experiences are best termed emergent precisely because the mixture of cognitive-emotional processes will not account for the complex, dialogical characteristics of religion.

Thus, the vast majority of scientific approaches to religion fail because, "Without an explanation of the unprecedented nature of religious emotions and experiences and an account of their genesis and value to those who seek them, scientifically-framed explanations of the origins of religion ignore what most begs for explanation." ${ }^{46}$ Since religion arises out of the interactions of social individuals where complexity explodes with the appearance of symbolic communication, we should not be surprised that religious phenomena across temporal and cultural boundaries vary greatly (from how the taboo is established to the structures of political society). Consequently, as philosopher of religion Mark C. Taylor argues, most of our theories or conceptions of religion are inadequate because they fail to account for the immense impact technological advances have had on global cultures. Consider his definition of religion:

An emergent, complex, adaptive network of symbols, myths, and rituals that, on the one hand, figure schemata of feeling, thinking, and acting in ways that lend life meaning and purpose and, on the other, disrupt, dislocate, and disfigure every stabilizing structure. ${ }^{47}$

Note especially his phrasing 'dis/figuring' and how it relates to meaningmaking. When Taylor uses the word 'figure,' he is employing the vast definitional distinctions of this term, from form or shape to calculate and decipher. More specifically, he points out that this concept is both a noun and a verb— "The activity of figuring through which figures emerge." ${ }^{8} 8$ This

\footnotetext{
45 Ibid.

46 Ibid.

47 Taylor, After God, 12.

48 Ibid., 20.
} 
exemplifies the meaning-making process we have continually noted. In Taylor's terms, this is how the imagination functions in the (de)construction of conceptual systems. He notes: "The activity of the imagination, therefore, has two sides: figuring, which is emergent (i.e., productive and creative), and refiguring, which is recombinant (i.e., reproductive and recreative)." ${ }^{\text {99 }}$ Taylor argues that the 'both/and' of monism or the 'either/or' of dualism fail to deal seriously with the operational logic of our emerging network culture. As an alternative, he emphasizes the 'neither/nor' of complexity. Adopting an approach that avoids dualistic favoritism is a first step in recognizing the importance of bodies. Breaking down the artificial separations that have plagued society - be they male/female, nature/culture, or body/mind - allows one to note the vast connections. ${ }^{{ }^{\circ}}$ Religions and their religious bodies cannot be left out as exemplified in Taylor's technical statement: "Every system is embedded in multiple networks that provide streams of data that must be processed. ${ }^{51}$

\section{Afterthought}

When considering these ideas in light of Deleuze and Guatarri, we can see that the narrative construction we necessarily undertake in meaningmaking processes has a direct connection to the organization of our bodies. What we learn from emergence is that this narrative feature of our lives, while typically taken for granted, is quite astounding when considered within the wider evolutionary context. In specific relation to religion and its role in this task, we might say that it is inevitable that religious narratives would be somewhat prevalent in human societies; that is, as a symbolic species, we demand a narrative to organize our world. As Deacon poignantly states, "We are embedded in stories told to us and generated during our lives, and these efficient packets of mnemonic information not only serve to create individual and social histories, but they also organize our conception of belonging in these contexts and create the ends that guide our actions." ${ }^{22}$

\footnotetext{
49 Ibid.

${ }^{50}$ Taylor tweaks the popular phrase 'to be is to be related' with a present-day maneuver, 'to be is to be connected.'

${ }^{51}$ Ibid., 13.

${ }^{52}$ Ibid.
} 
Religions, or meaning-making practices, matter bodies through the ways they connect us and guide our values toward certain actions and not others. Meaning-making, then, is not about finding a clearing above the fray from which to see the universe objectively, which has been the project of many scientists, philosophers, and theologians throughout human histories. From the perspective of emergence theory and the philosophy of Deleuze and Guattari, we can argue that bodies matter and are shaped by ideas. To formulate an understanding of the human that transcends the rest of nature (including sometimes the material body) is to neglect our focus on how our ideas matter and instead forces matter into ideas that end up promoting violence toward many bodies. Perhaps with an understanding of meaning-making practices that emerge from and return to affect bodies, our ideas, values, and even metaphysics will be as good as they are able to promote the thriving of diverse, evolving, planetary bodies. 



\title{
TONGUES OF MEN AND ANGELS: ASSESSING THE NEURAL CORRELATES OF GLOSSOLALIA
}

\author{
John J. McGraw
}

The accelerating popularity of Charismatic Christianity has brought with it a host of new sensibilities and ritual practices. Glossolalia, or 'speaking in tongues,' stands out among these as a particularly dramatic innovation. Typically staid churchgoers, once touched by the Holy Spirit, begin to utter strings of syllables that some claim to be the 'language of angels.' Recent neuroimaging studies have highlighted differences in the brains of subjects performing glossolalia in comparison to those same subjects singing a Church hymn. An investigation of the neural correlates of glossolalia highlights the importance of studying the bodily dimensions of ritual practice. But an informed analysis does not reduce social and behavioral complexities to physiological changes; rather, juxtaposing the correlates of human action from a variety of perspectives - in this case the social, the bodily, and the behavioral-suggests productive new approaches to the study of ritual. Having received the attentions of numerous scholars during the 2oth and 21st centuries, glossolalia provides an excellent test case for this correlational approach to human action.

Glossolalia probably derives its inspiration, and much of its scriptural support, from episodes in Acts of the Apostles and in Paul's First Letter to the Corinthians. ${ }^{1}$ Therein lay examples of glossolalia and xenoglossia. Considered to be the language of angels ${ }^{2}$ or even the pre-Babel 'original' human language, ${ }^{3}$ glossolalia comes out as a set of unintelligible utterances by the inspired speaker. Sometimes another member of the congregation may attempt to translate this speech into the vernacular but mostly it is left to flow out uninterpreted and free of denotative meaning. ${ }^{4}$ Xenoglossia, in contrast, is the vocalization of a foreign language unknown to the speaker. ${ }^{5}$

\footnotetext{
${ }^{1}$ Coogan, Michael David, et al. The new Oxford annotated Bible.

2 1 Corinthians 13:1.

3 Mills, Watson E. Speaking in Tongues, 2.

4 Samarin, William. Tongues of Men and Angels, 159-173.

5 Goodman, Felicitas. Speaking in Tongues, xv.; Malony, H. Newton and Lovekin, A. Adams, Glossolalia, 8.
} 
To the outsider who stumbles upon a Pentecostal revival, the sight of a flailing mass loud with moaning and cryptic utterances can be disorienting, to say the least. But for the Pentecostal himself, this once arcane practice has become doctrinal fixture and a uniquely beloved expression of faith, sure evidence of 'baptism with the Holy Spirit.'

A source of considerable conjecture, numerous 'explanations' of these practices have been suggested since Biblical times. In Acts, the writer recounts an episode when the Holy Spirit came upon the followers of Jesus and manifested 'tongues of fire' upon their heads causing them to speak in foreign languages:

... they were all together in one place. And suddenly from heaven there came a sound like the rush of a violent wind, and it filled the entire house where they were sitting. Divided tongues, as of fire, appeared among them, and a tongue rested on each of them. All of them were filled with the Holy Spirit and began to speak in other languages, as the Spirit gave them ability. Now there were devout Jews from every nation under heaven living in Jerusalem. And at this sound the crowd gathered and was bewildered, because each one heard them speaking in the native language of each. Amazed and astonished, they asked, 'Are not all these who are speaking Galileans? And how is it that we hear, each of us, in our own native language?'

The bestowal of this 'gift of tongues' by the Holy Spirit on the feast of Pentecost lends the modern sect its name. But even at the beginning, during the height of the Pentecostal miracle, skeptical witnesses were willing to shrug it off as nothing more than drunkenness. ${ }^{8}$

Paul thought of glossolalia as just one of many spiritual gifts, gifts he considered to be superfluous in comparison to more fundamental Christian virtues: "If I speak in the tongues of mortals and of angels, but do not have love, I am a noisy gong or a clanging cymbal." ${ }^{\prime 9}$ Paul's poetic discussion of love in First Corinthians has become a mainstay of Christian wedding celebrations though few wedding-goers appreciate the polemical nature of the passage. While Paul valued the gift of tongues enough to declare his own superiority at it compared to the Corinthian hacks whom he chastised, he also warned them against taking the practice too seriously. Far better, says Paul, to speak five intelligible words than ten thousand in a tongue. ${ }^{10}$

\footnotetext{
${ }^{6}$ Mills, Watson E. Speaking in Tongues, 5; Spittler, Russell. Glossolalia, 670; Synan, Vinson. The Holiness-Pentecostal Tradition, 254-255.

7 Acts 2: 1-8.

8 Acts 2: 13.

91 Corinthians 13: 1-2.

${ }_{10}$ Corinthians 14: 18-19.
} 
During the two millennia that have passed since Paul wrote these words, glossolalia has persisted in the Christian tradition as an undercurrent - an occulted river-that has only bubbled to the surface on rare occasions. But with the rise of Pentecostalism in the early 2oth century United States, glossolalia would gush forth to attract renewed attention. A great many scholars would attempt to explain this arresting phenomenon, an apparent atavism in the century of Metropolis and relativity.

William Samarin, a linguist who studied glossolalia at length, defined it as "a verbal behavior that consists of using a certain number of consonants and vowels in the constitution of a limited number of syllables that in turn are organized into larger units that are taken apart and rearranged pseudogrammatically." Samarin came to the conclusion that none of the instances of glossolalia he analyzed possessed the structure of a viable language. He maintained that "glossolalia is fundamentally not language. All specimens of glossolalia that have ever been studied have produced no features that would even suggest that they reflect some kind of communicative system."12 This is in direct contrast to the claims of xenoglossia in Acts 2 and the instances of apparent xenoglossia witnessed by early adherents of Pentecostalism such as Charles Parham and the students of his Bethel Bible School: "A remarkable claim made during these meetings was that the students, Americans all, spoke in twenty-one known languages, including French, German, Swedish, Bohemian, Chinese, Japanese, Hungarian, Bulgarian, Russian, Italian, Spanish, and Norwegian."13 Parham and his students were the first to identify the gift of tongues as evidence of baptism with the Holy Spirit, thus sparking the Pentecostal conflagration. One of these students, William Joseph Seymour, was responsible for the 1906 Azusa Street Revival in Los Angeles which many see as the inauguration of modern Pentecostalism. ${ }^{14}$ The phenomenon that these proselytes experienced a century ago was proof positive to them of divine intervention; some would begin missions to far flung parts of the globe without any language training, fully convinced that the Holy Spirit had supplied them with the necessary tools for speaking to any group. ${ }^{15}$ Many contemporary Pentecostals are unwilling to make strong claims about the validity of xenoglossia; for them, it is enough that glossolalia serve as a 'private

\footnotetext{
${ }^{11}$ Samarin, William. Tongues of Men and Angels, 120.

12 Ibid., 227.

13 Synan, Vinson. The Holiness-Pentecostal Tradition, 90-92.

4 Ibid., 97-100.

15 Parham, Charles. Kol Kare Bomidbar, 31-32.
} 
prayer language. ${ }^{16}$ But according to Samarin's work, even this must be an illusion. Glossolalia does not possess the necessary elements of language and simply could not function as a system of communication. ${ }^{17}$ If this speech practice is not a language then why do its practitioners engage in it? Pentecostals ritually induce glossolalia because it provides a 'religious experience' and because “... it is evidence of 'being filled with the Holy Spirit'. ${ }^{\prime 18}$ Glossolalia serves as both a demonstration of divine favor and as a powerful, and uncanny, experience.

Psychological studies have provided varying interpretations of glossolalia. Some consider it to be indicative of a mental disease, ${ }^{19}$ while others think it promotes psychological well-being. ${ }^{20}$ This chapter will avoid such normative judgments and proceed from a novel approach, namely that glossolalia promotes neural and behavioral disinhibition, specifically disinhibition resulting from selective downregulation of circuits in the prefrontal cortex of the brain. ${ }^{21}$ Further, this neurologically significant property-its ability to engender a typically mild altered state of consciousness-helps to illuminate the ritual purpose of speaking in tongues. Glossolalia creates a state of mind that facilitates transitions between oppositional cultural values. These include control/spontaneity, individual/group, and sacred/ profane. The ability of glossolalia to facilitate transitions between such values suggests it to be liminal in nature. ${ }^{22}$

\section{Glossolalia and the Brain}

One of the most recent investigations of glossolalia, by Andrew Newberg and colleagues at the University of Pennsylvania's Center for Spirituality and the Mind, employed neuroimaging in order to clarify what occurs in the brains of glossolalists during the ritual practice. ${ }^{23}$ Newberg and

${ }^{16}$ Liberman, Mark. "Private Prayer Language."

${ }^{17}$ Samarin, William. Tongues of Men and Angels, 121-128.

${ }^{18}$ Samarin, William. "Sociolinguistic vs. Neurophysiological Explanations for Glossolalia," 293 .

${ }^{19}$ Cutten, George Barton. Speaking with Tongues, 157-184.

${ }^{20}$ Lovekin, Adams and Malony, H. Newton. "Religious Glossolalia," 391.

${ }^{21}$ Dietrich, Arne. "Functional Neuroanatomy of Altered States of Consciousness," 249250; Newberg, Andrew, et al. "The Measurement of Regional Cerebral Blood Flow During Glossolalia," 70.

${ }^{22}$ van Gennep, Arnold. The Rites of Passage, 182-186.

${ }^{23}$ Newberg, Andrew, et al. "The Measurement of Regional Cerebral Blood Flow During Glossolalia"; Newberg, Andrew and Waldman, Mark. Why We Believe What We Believe. 
colleagues had already undertaken similar studies to record the neural correlates of religious experiences. A study of glossolalia would provide a comparison for these other studies as well as offer insights into the experience of glossolalia itself. The team recruited five women with Charismatic and Pentecostal Christian backgrounds who had extensive experience speaking in tongues. The experiment recorded alterations in the blood flow of the brain during periods of glossolalia and during periods of devotional singing. Glossolalia is experientially quite different than singing because the singer generally perceives intentional control over her actions. But during glossolalia, as numerous practitioners relate, one loses this sense of control. ${ }^{24}$

Significantly, the study found "that the frontal lobes showed decreased perfusion during glossolalia... consistent with the subjects' description of a lack of intentional control over the performance of glossolalia., ${ }^{25}$ This point is important because it relates to broader theories about the role of the frontal lobes in consciousness and volition. ${ }^{26}$ In their 2006 paper, Newberg and colleagues did not spend much time discussing why decreased blood perfusion in the frontal lobes (especially in the prefrontal cortex) might correlate to subjects' descriptions of reduced intentional control. This finding deserves a lengthier treatment.

The prefrontal cortex is intricately involved in 'executive control'those processes of willing, planning, intention, decision-making, and self-concept that stand out as quintessentially human faculties ${ }^{27}$ (see Figure 1). It is a critically important 'association area,' a place that "sends and receives projections from virtually all cortical sensory systems, motor systems, and many subcortical structures. ${ }^{{ }^{2} 8}$ Joaquín Fuster notes that the prefrontal cortex fosters 'temporal integration,' the purposeful weaving together of thought and behavior in time. ${ }^{29}$ Fuster's notion of temporal integration builds upon more commonly discussed ideas about 'working memory.' Working memory is the short term memory required for the

\footnotetext{
${ }^{24}$ Goodman, Felicitas. Speaking in Tongues, 28-57.

${ }_{25}$ Newberg, Andrew, et al. "The Measurement of Regional Cerebral Blood Flow During Glossolalia," 70.

${ }_{26}$ Dietrich, Arne. "Functional Neuroanatomy of Altered States of Consciousness"; Fuster, Joaquín. The Prefrontal Cortex.

${ }^{27}$ Goldberg, Elkhonon. The Executive Brain; Goldberg, Elkhonon. The New Executive Brain.

${ }_{28}$ Miller, E.K. and Cohen, J.D. “An Integrative Theory of Prefrontal Cortex Function,” 168.

${ }^{29}$ Fuster, J.M. “The Prefrontal Cortex — an Update; Time is of the Essence," 324.
} 


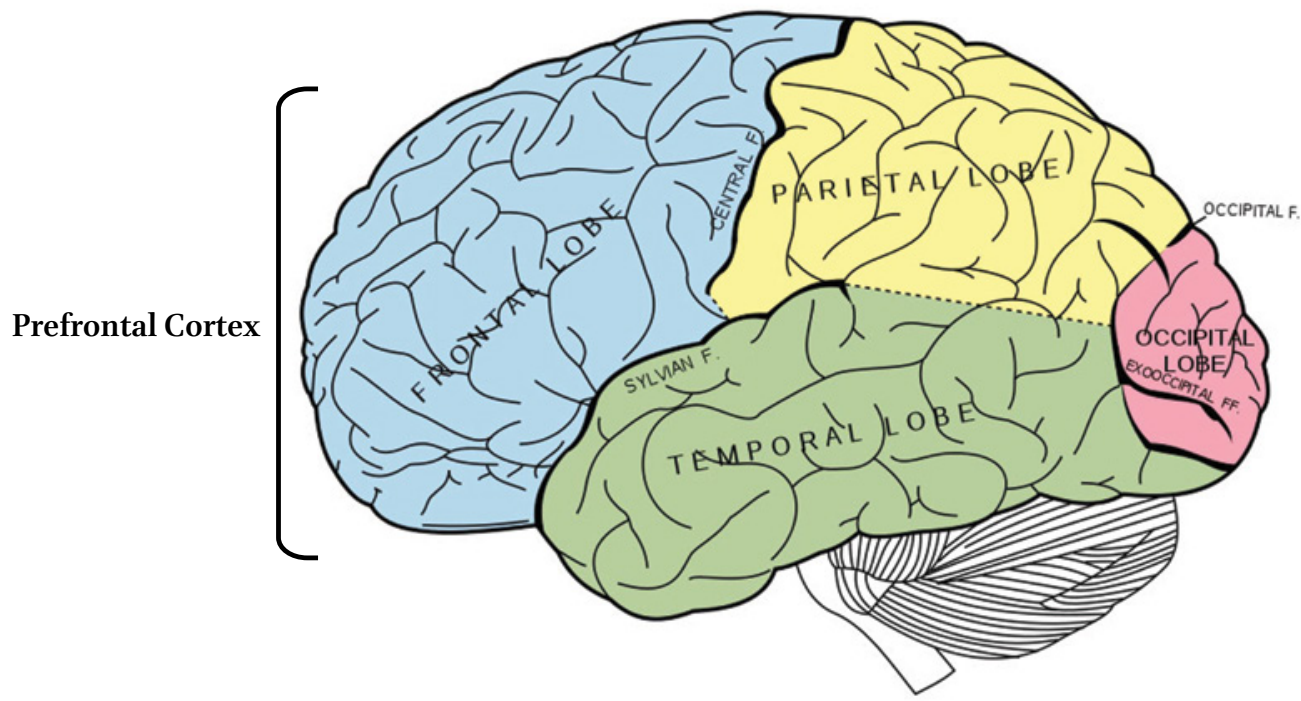

Figure 1. The prefrontal cortex.

coordination of behavior and cognitive representations (sensations, long term memories, judgments) in any sequence of action. Fuster writes that working memory is "practically inextricable from attention." $3^{\circ}$ Together, attention and working memory form the larger part of conscious, deliberate experience..$^{31}$

It can be argued that the prefrontal cortex provides the neural foundation for enculturation. Indeed, the Russian neuropsychologist Alexander Luria referred to this part of the brain as "the organ of civilization." ${ }^{22}$ The complex associations and general attunement of the person to a particular time and place require the executive control functions of the prefrontal cortex. 'Lower-level' capacities of the nervous system, the most basic aspects of sensation, awareness, endocrine response and the like, tend to show a cross-cultural reliability. It is human behavior, coupled with the more subtle aspects of perception and cognition, which varies. This

$3^{30}$ Fuster, Joaquín. The Prefrontal Cortex, 4.

${ }^{31}$ Baars, Bernard J. "Attention and Consciousness," 225-254; Dehaene, S. and Naccache, L. "Towards a Cognitive Neuroscience of Consciousness," 1-2.

${ }^{32}$ Goldberg, Elkhonon. The Executive Brain, xvi. 
coordination of person and context derives a great deal from the executive processes directed by the prefrontal cortex.

But the prefrontal cortex is also a highly sensitive and labile piece of tissue. The eminent 19th century neurologist, John Hughlings Jackson, held that the brain was organized hierarchically from the lower, more ancient structures, to the higher, more recent ones. He believed that the evolutionarily 'young' parts of the brain had a lower threshold for upset and 'dissolution. ${ }^{33}$ In The Executive Brain, Elkhonon Goldberg expressed it this way:

... the frontal lobes are more vulnerable and are affected in a broader range of brain disorders, neurodevelopmental, neuropsychiatric, neurogeriatric, and so on, than any other part of the brain. The frontal lobes have an exceptionally low "functional breakdown threshold." This led me many years ago to conclude that frontal lobe dysfunction is to brain disease what fever is to bacterial infection. It is both highly predictable and often nonspecific.... I believe that the frontal lobes' unique vulnerability is the price they pay for the exceptional richness of their connections. ${ }^{34}$

The 'exceptional richness' of frontal lobe connections, to use Goldberg's phrase, suggests how the highly arousing context and 'sensory driving' of Charismatic services might affect consciousness..$^{35}$ By upsetting frontal lobe activity, the ritual context of glossolalia helps to create a shift in consciousness and in executive processes. The ritual import of these mental states will be addressed below.

In their study, Newberg and colleagues found a 9\% decrease in blood perfusion of the dorsolateral areas of the prefrontal cortex when subjects performed glossolalia. Interestingly, Chris Frith and colleagues noted this same area as significant in their own studies of willed behavior. ${ }^{6}$ They discovered that voluntary word generation was associated with increased blood flow in the dorsolateral areas of the left prefrontal cortex (most verbal activity finds its correlates in cortical areas on the left side of the brain) while willed movement was associated with increased blood flow on both sides of the dorsolateral prefrontal cortex. J. Allan Hobson detected a noteworthy reduction in the activity of the dorsolateral prefrontal cortex

\footnotetext{
33 Jackson, J.H. "The Croonian Lectures on Evolution and Dissolution of the Nervous System," 704-705.

34 Goldberg, Elkhonon. The Executive Brain, 115.

35 Goodman, Felicitas. Speaking in Tongues, 75-76.

${ }^{36}$ Frith, C.D., et al. "Willed Action and the Prefrontal Cortex in Man," 241.
} 
during REM sleep. He concluded that the diminished role of memory, volition, and general 'spaciness' of REM sleep might be due to this particular subtraction. ${ }^{37}$ Jose Manuel De La Fuente and colleagues noted a decreased metabolism in the prefrontal cortex (and particularly in the dorsolateral areas) in groups of borderline personality disorder patients in comparison to control subjects. ${ }^{38}$ They hypothesized that the chronic feelings of depersonalization and unreality of many borderline personality disorder patients could be related to these findings. Reflecting on these studies, it would seem that the dorsolateral prefrontal cortex is involved in the production of willed behavior and the attendant sense of 'normalcy' that accompanies it. ${ }^{39}$ This sense of willed action may derive, in large part, from the activity of working memory since the dorsolateral prefrontal cortex has often been implicated in working memory tasks. ${ }^{40}$ Without working memory to help weave together internal and external cognitive resources in the loom of time, deliberate action-and its accompanied sense of will—may be diminished.

\section{Transient Hypofrontality Hypothesis}

In his 'transient hypofrontality hypothesis,' Arne Dietrich proposes that altered states of consciousness result from temporary alterations in the prefrontal cortex: "a state of diminished metabolism in prefrontal regions can account for a wide variety of well-documented psychological and neurological effects of altered states." ${ }^{41}$ Again, the prefrontal cortex is known for its involvement in behaviors that require working memory, attention, decision-making, volition, planning, and the general coordination of perception, memory, and thought. It is easy to imagine how the attenuation of these faculties can lead to odd experiences and behaviors. As already mentioned, the prefrontal cortex, the latest development of the brain in terms of human evolution, is especially vulnerable to disturbance..$^{42}$ Because of this, physical exhaustion, intense sensory stimulation,

37 Hobson, J. Allan. The Dream Drugstore, 92.

${ }^{8}$ De la Fuente, José Manuel, et al. "Brain Glucose Metabolism in Borderline Personality Disorder," 536.

39 Llhermite, F. "Human Autonomy and the Frontal Lobes," 343.

${ }^{40}$ Fuster, Joaquín. The Prefrontal Cortex, 8o; Goldman-Rakic, P.S., Cools, A.R., and Srivastava, K. “The Prefrontal Landscape," 1446.

${ }^{41}$ Dietrich, Arne. "Functional Neuroanatomy of Altered States of Consciousness," 250.

$4^{2}$ Dietrich, Arne. Introduction to Consciousness. 
high arousal, drugs, blood sugar level, and a host of other changes that impinge upon the organism can easily upset the cognitive balance and lead to a 'phenomenological subtraction' of the particular supplements to conscious experience that the prefrontal cortex provides. ${ }^{43}$ Glossolalia appears to be a behavioral practice that can facilitate the kinds of temporary alterations in prefrontal circuits that engender altered states of consciousness.

That glossolalia may induce, or result from, altered states of consciousness is not a new hypothesis. As noted above, even in Biblical times the ascription of glossolalia to the altered state of alcoholic inebriation was readily made. ${ }^{44}$ More recently, Felicitas Goodman engaged in vigorous debates to establish glossolalia as an 'artifact of trance. ${ }^{45}$ She defined glossolalia as "an act of vocalization in trance." ${ }^{\text {"6 }}$ Goodman felt glossolalia to be a cross-culturally reliable consequence of 'hyperarousal dissociation,' a state of trance that results from a type of patterned sensory stimulation known as 'driving. ${ }^{47}$ Sensory driving refers to a host of rhythmic stimuli used in ritual settings to elicit altered states of consciousness; examples include drumming, chanting, and dancing. Ultimately, Goodman interprets glossolalia as an artifact of 'hyperarousal dissociation' that verbally expresses, on a surface level, 'deep structures' in consciousness that are cross-culturally reliable, a notion inspired by Chomsky's ideas about the cross-culturally reliable 'deep structures' present in language.$^{48} \mathrm{Anticipating}$ a recent discussion by Tanya Luhrmann and colleagues about the learned aspects of ritual behavior, ${ }^{49}$ Goodman noted that "the glossolalist has simply learned, by imitation, or sometimes spontaneously, to relinquish some of his controls, to dissociate. ${ }^{n 0}$ For Goodman (as for Luhrmann), ritual behavior, even if based in cross-culturally reliable body states such as trance, dissociation, or 'absorption,' involves learning as well: "what the artifact of the trance will be, is decided by the respective learning situation or cultural expectation. ${ }^{{ }^{1}}$

\footnotetext{
${ }^{43}$ Hobson, J. Allan. The Dream Drugstore, 112.

${ }_{44}$ Acts 2:13.

${ }^{45}$ Goodman, Felicitas. "Phonetic Analysis of Glossolalia in Four Cultural Settings," 238.

${ }^{46}$ Goodman, Felicitas. Speaking in Tongues, 185.

47 Ibid., $74-76$.

${ }^{48}$ Ibid., 8.

${ }^{49}$ Luhrmann, T.M., Nusbaum, Howard, and Thisted, Ronald. "The Absorption Hypothesis."

${ }^{50}$ Goodman, Felicitas. "Phonetic Analysis of Glossolalia in Four Cultural Settings," 238.

${ }^{51}$ Ibid., 238.
} 
The greatest detractor of the 'trance theory' of glossolalia, the aforementioned William Samarin, believed that Goodman's analysis was deeply flawed. $5^{2}$ While Goodman had considered consistencies in glossolalic speech in different cultural settings to be indicative of their production by the state of trance itself, Samarin disputed the overall reliability of these utterances. He also asserted that whatever consistencies were present across cultures could be more parsimoniously explained as learned behavior from the extended community of practitioners. ${ }^{53}$ In other words, he preferred the parsimonious explanation that similarities in glossolalia across cultures were merely adoptions of one community's practices by another. The ready accessibility of international travel made such opportunities for learning possible. But language issues aside, Goodman's investigations of glossolalia uncovered an interesting residual effect of the practice: "An important psychological correlate of this mental state is a considerable depression of inhibitions, making people say or do things that they would not if they were not in this altered mental state." ${ }^{44}$ Goodman's theories emphasized the relationship between glossolalia practice and alterations in experience, an assertion amply supported by the statements of the people she interviewed who noted how experiences of glossolalia left them 'feeling good.'55

Additional challenges to the theory that glossolalia is necessarily related to altered states of consciousness surface from time to time. In Language, Charisma, and Creativity, Thomas Csordas amusingly recounts his worries about being driven to a prayer meeting by some Catholic Pentecostals in the early 1970s:

I was in the back seat of the car as both people in front devoutly spoke in tongues. Theories of trance and altered states of consciousness completely preoccupied my thoughts as we approached a red traffic light. I wondered whether someone in trance could stop in time, and why my first empirical evidence on the topic had to be acquired with such apparent risk. Nothing happened. I had no sense even that the driver's reaction time was slowed..$^{6}$

In this case, as well as in other studies of the practice, ${ }^{57}$ speaking in tongues hardly resembled a mystical state of ecstasy (see Figure 2).

\footnotetext{
${ }^{52}$ Samarin, William J. "Sociolinguistic vs. Neurophysiological Explanations for Glossolalia," 294.

53 Ibid., 294.

${ }^{54}$ Goodman, Felicitas. “Apostolics of Yucatán,” 186.

${ }^{55}$ Goodman, Felicitas. "Phonetic Analysis of Glossolalia in Four Cultural Settings," 230.

${ }^{56}$ Csordas, Thomas J. Language, Charisma, and Creativity, 41.

${ }^{57}$ Spanos, Nicholas P. and Hewitt, Erin C. "Glossolalia: A Test of the 'Trance' and Psychopathology Hypotheses."
} 


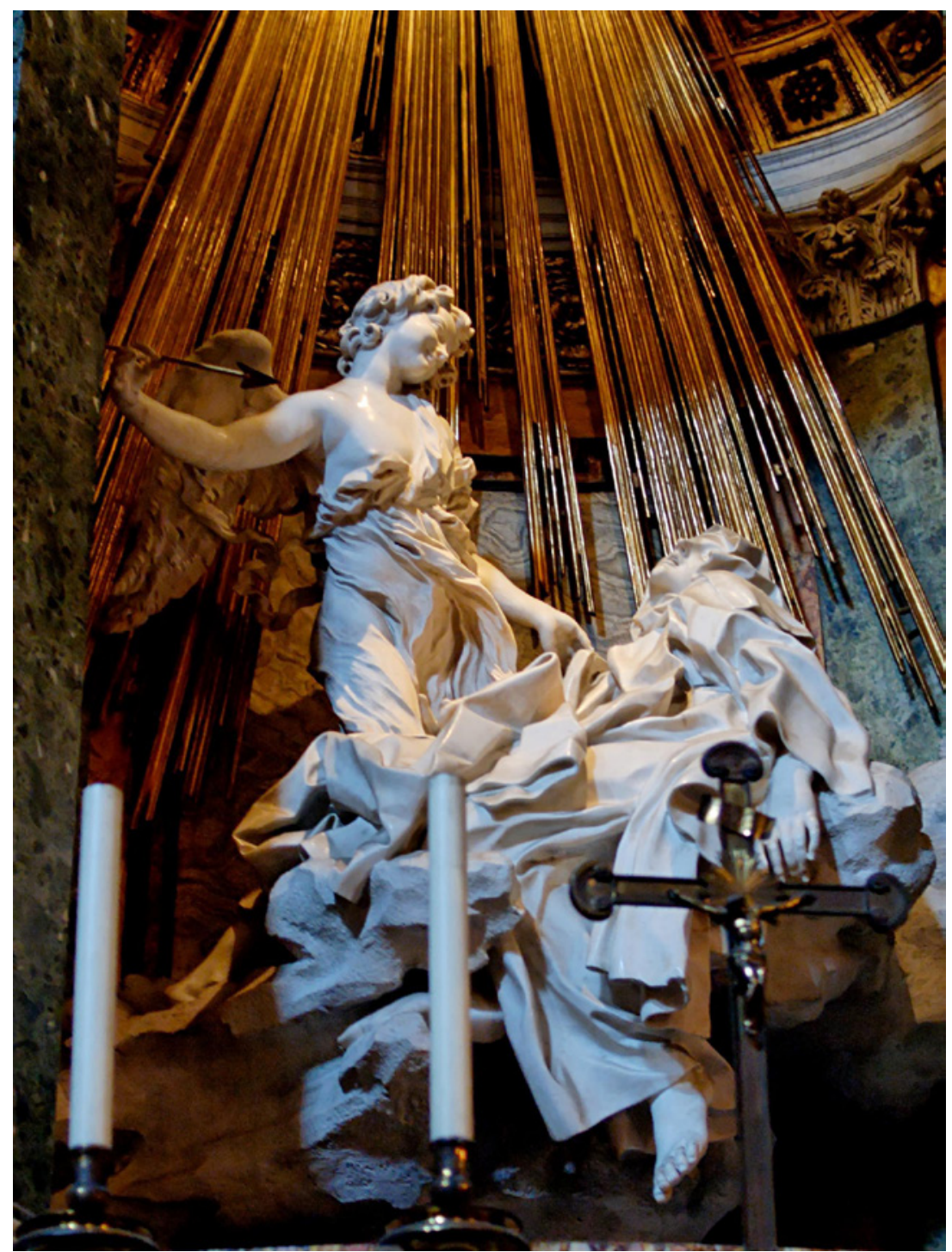

Figure 2. Bernini's statue of the Spanish mystic, Santa Teresa, remains a classic illustration of mystical ecstasy. 
Rather, numerous instances of glossolalia occur without any noticeable departure from typical states of consiousness. Glossolalists have been known to communicate with other Pentecostals normally, breakaway in mid-sentence for a bit of glossolalia, and then quickly resume their discussion. ${ }^{5}$ This does not suggest a profound change in consciousness. But as common as such examples of 'non-dissociated' glossolalia are, many Pentecostals are renowned for their ecstatic practices:

... they shout, scream, cry, sing, jerk, jump, twitch, whistle, hoot, gesture, sway, swoon, tremble, strut, goosestep, stamp, and incoherently 'speak in new tongues.' When in deep dissociated trance the members appear as if they were intoxicated, and their faces are very similar to those seen with reactions induced by mescaline and LSD -25.59

Ultimately, glossolalia can be attested to by those in normal states of consciousness and by those in highly dissociated/altered states of consciousness. It would seem that a significant alteration of consciousness is not necessary in order to produce glossolalia. But while an altered state of conciousness may not be a requirement for the production of glossolalic speech, it is likely that behavioral disinhibition (in this case, speech disinhibition) and glossolalia go hand-in-hand. Glossolalia is speech disinhibition. Glossolalia occurs in humdrum states, in mildly dissociated states, and in highly dissociated states. But Goodman's 'strong' theory of glossolalia as an artifact of hyperarousal dissociation does not accurately convey the range of these ritual practices and experiences.

Conceiving glossolalia as deriving from and further eliciting behavioral and neural disinhibition allows for a more nuanced approach to this ritual practice. Employing the transient hypofrontality hypothesis, behavioral disinhibition could be labeled an altered state of consciousness even if it does not usually come across as dramatically as trance or mystical ecstasy. The disinhibition that accompanies glossolalia can be compared to Csikszentmihalyi's ideas about 'flow,' a state that accompanies challenging activities and induces a sense of focus as well as a reduction in selfconsciousness $^{60}$ and to Luhrman and colleague's recent discussion about 'absorption,' the capacity for immersion in such things as a good novel, a deeply felt prayer, or a meditative mantra.$^{61}$ All the various degrees of

\footnotetext{
${ }_{5}^{8}$ Ewing, Heidi and Grady, Rachel. Jesus Camp.

${ }_{59}$ Schwarz, B.E. "Ordeal by Serpents, Fire and Strychnine," 408-409.

${ }^{60}$ Csikszentmihalyi, Mihaly. Flow: The Psychology of Optimal Experience.

${ }^{61}$ Luhrmann, T.M., Nusbaum, Howard, and Thisted, Ronald. "The Absorption Hypothesis," 75 .
} 
absorption, dissociation, and disinhibition are worthy of being labeled as altered states of consciousness even if they are subtly graded and often much 'lighter' in their appearance and felt experience than the more traditional, if not stereotypical, ideas about trance and ecstasy. The disinhibition that accompanies such states proceeds from the same process of frontal lobe downregulation that Dietrich outlines. ${ }^{62}$

In contrast to the states of mind depicted in 'strong' theories of trance, behavioral disinhibition is a common experience. Perhaps the most typical form of disinhibition is that which accompanies mild alcoholic inebriation. Alcohol serves as a 'social lubricant' because it allows people to get past their inhibitions to talk, to make jokes, and to dance. Those who are 'self-conscious' seem to lessen their critical ruminations when inebriated, thus allowing more spontaneous social interaction. By achieving some disinhibition, the individual usually finds it easier to take the sorts of risks that can lead to enjoyment. ${ }^{63}$

In "Functional Neuroanatomy of Altered States of Consciousness" Dietrich investigates such varied states as dreaming, endurance running, meditation, and hypnosis. Dietrich's transient hypofrontality hypothesis allows for a more fine-grained analysis of a broad spectrum of altered states than previous theories of dissociation and trance. Whereas trance could be present or not, light or deep, the transient hypofrontality hypothesis permits a continuum of altered states mediated by the downregulation of prefrontal circuits. Recent neuroimaging techniques, including those put to use by Newberg and colleagues, enable statistical assessments of the various configurations of transient hypofrontality. ${ }^{64}$ The job of future theorists and researchers will be to characterize the details of these configurations.

\section{Ritual Disinhibition and Psychocultural Themes}

In reviewing the literature on glossolalia and its neural correlates, it becomes apparent that neural and behavioral disinhibition are paired in this ritual practice. What purpose might such a combination serve? Is there something about this disinhibition, in a ritual context, that has led

\footnotetext{
${ }^{62}$ Dietrich, Arne. "Functional Neuroanatomy of Altered States of Consciousness"; Dietrich, Arne. "Neurocognitive Mechanisms Underlying the Experience of Flow."

${ }_{63}$ Hanson, Glen, Venturelli, Peter J., and Fleckenstein, Annette E. Drugs and Society, 195.

${ }^{64}$ Azari, Nina P. "Neuroimaging Studies of Religious Experience: A Critical Review."
} 
to the wide popularity of the practice? As mentioned before, the experiences that go along with this disinhibiton would suggest that glossolalia is a ritual practice that fosters liminality. ${ }^{65}$ As Victor Turner defines it, liminality:

... means a state or process which is betwixt-and-between the normal, dayto-day cultural and social states and processes of getting and spending, preserving law and order, and registering structual status... another way of putting it would be to say that the liminal in sociocultural process is similar to the subjunctive mood in verbs-just as mundane sociostructural activites resemble the indicative mood. ${ }^{66}$

As a technique that elicits disinhibition, glossolalia facilitates movement between roles, values, and behaviors. To use an analogy, glossolalia is akin to a car's gear shift. To shift from one gear to another, one needs 'play' in the shifter-a neutral state between the disengagement of one gear and the engagement of the next. Glossolalia, as a ritual technique of disinhibition, permits a similar 'play' in the sociocultural context.

One key to understanding the sociocultural context is the study of cultural 'themes.' Morris Opler defines a cultural theme as a "postulate or position, declared or implied, and usually controlling behavior or stimulating activity, which is tacitly approved or openly promoted in a society." ${ }^{67}$ In his study of the Catholic Charismatic Renewal, Csordas built on Opler's work and identified 'control' and 'spontaneity' as essential 'psychocultural themes' in North American culture. ${ }^{68}$ These psychocultural themes are highly valued by Catholic Charismatics. But it would seem hard to discuss control or spontaneity as individual themes when, in fact, they more accurately reflect the poles of a behavioral spectrum. On one side of this spectrum is the controlled self necessary for civil society while on the other side is the spontaneous self so precious in the context of intimate relationships and encouraged in celebrations. A continuum based on opposites has appeared time and again in theories of the person and of culture. Plato reified the split between reason and the passions, Nietzsche extolled the interplay of the Apollonian and the Dionysian, and Freud advanced a model of the mind in conflict with itself, stretched tautly between the controlled pursuits of the ego and the hazardous desires

\footnotetext{
${ }^{6}$ van Gennep, Arnold. The Rites of Passage, 21.

${ }_{66}$ Turner, Victor. "Frame, Flow, and Reflection," 465.

${ }_{7}$ Opler, Morris Edward. "Themes as Dynamic Forces in Culture," 198.

${ }^{68}$ Csordas, Thomas J. Language, Charisma, and Creativity, 66.
} 
of the unconscious id. The practice of glossolalia seems a fit instance of enantiodromia - release from a tense balance of opposites-in that it helps to mediate highly charged, oppositional roles in human behavior. In Aspects of the Masculine, Carl Jung discusses these oppositional forces of the mind: "This characteristic phenomenon practically always occurs when an extreme, one-sided tendency dominates conscious life; in time an equally powerful counterposition is built up, which first inhibits the conscious performance and subsequently breaks through the conscious control." ${ }^{69}$ Without refined channels for these 'eruptions,' the person may face dangerous upheavals in emotion and thought. Sophisticated social systems permit, and create, conditions for just such catharsis. Sporting events, parties, festivals, and ritual activities are just a few of the circumscribed arenas for expressing this tense balance of opposities.

The paradigmatic dichotomy between control and spontaneity plays an important role in Pentecostal culture. Pentecostals value self-control and typically live Puritanical lifestyles-often abstaining from alcohol and other drugs. Resonating Freud's psychodynamic account of the mind, Morton Kelsey suggests that the restricted behaviors of Pentecostalism may create the sort of person most hungry for the experience of glossolalia: "...the more inhibited and out of touch with the unconscious, the more likely a person is to be a candidate for tongues, which is undoubtedly preferable to most neurotic forms of behavior as a resolution to tension and inhibitions." ${ }^{70}$ In such a fastidious lifestyle the sorts of spontaneity available through ritual practices-especially the more dramatic practices like glossolalia - may be some of the few outlets for anxiety. Samarin discusses this function in its sociocultural context:

Another practical function of glossolalia is to contribute to the spontaneity of a meeting. Because a discourse or utterance in tongues can come unexpectedly at almost any point, it reminds the participants that this is an open meeting: anything can be done by anybody. This principle-sacred serendipity it might be called-is a dominant one in the charismatic ethos, without which the culture of these groups cannot be understood..$^{71}$

Pentecostalism has constructed a framework for self-control that indulges spontaneity where it is most safe to do so-within the bounds of ritual and in the company of other practitioners. Keeping the self constrained by

69 Jung, C.G. Aspects of the Masculine, 709.

$7^{\circ}$ Kelsey, Morton T. Tongue Speaking, 199.

${ }^{71}$ Samarin, William J. Tongues of Men and Angels, 215. 
strict codes of behavior, Pentecostals achieve an esteemed image of themselves and their movement. But within their ritual spaces they engage in a set of cathartic releases-embodied experiences of disinhibition - that helps them to achieve a balance between ascetic control and spontaneous disinhibition.

Pentecostalism has taken root worldwide and proliferates among people whose traditional behavioral environment is marked by collective notions and practices. The duty of the self is always a challenging one, as Csordas writes: "... the problem of subjectivity is that we are never completely ourselves, and the problem of intersubjectivity is that we are never in accord with others." ${ }^{72}$ As problematic a dualism as any, the self and other is highly confused, further evidence for the insufficiency of present categories. Steven Parish notes that "the self is never independent of cultural life, nor ever passively a construction of culture." ${ }^{73}$ What self develops without the shaping influences of a particular time and place? Everything that is now inside the person, was once outside. ${ }^{74}$ And yet what society, culture, or group is made up of superorganic 'stuff'? Just as the person needs others to be herself so does the collective depend on each person. But a particular challenge posed by the globalizing world is the disaggregation of traditional, often collective environments. In short, the self is becoming increasingly individuated. If nothing else, at least the understanding that the person has greater freedoms than may be the fact, looms large in the contemporary world. One (apparently) chooses where to live, with whom to interact, and, perhaps most importantly in the context of globalization, what to buy.

Protestant Christianity has long facilitated this individuating process. Some of the ways that Protestantism heightens individualism is by establishing authority in scripture and emphasizing the doctrine of personal salvation..$^{75}$ Whatever one's background, however enmeshed one's roles are within family and community, such dimensions become irrelevant before the throne of God. Pentecostalism retains this message of individual redemption but fosters particularly robust religious communities. Even the ritual practices of Pentecostal services are eminently social, collective performances. Within this milieu, however, glossolalia stands out as something that remains utterly personal. One does not mimic another's

${ }^{72}$ Csordas, Thomas J. “Asymptote of the Ineffable," 163.

73 Parish, Steven M. Subjectivity and Suffering in American Culture: Possible Selves, 185.

74 Hallowell, A. Irving. Culture and Experience, 88.

75 Marty, Martin E. "Protestantism." 
glossolalia nor does one will his own, rather one becomes the vessel for the divine language. Within this free space, a radical experiment of individuality ensues - one that is intimately personal but, at the same time, publicly performed and sanctioned. In glossolalia, the self achieves an indeterminate status, hovering between two worlds, as it were. ${ }^{76}$

The experience that accompanies glossolalia helps in the transition to new behavioral environments. In Fire from Heaven, Harvey Cox discusses how glossolalia flourishes in a context of 'cultural displacement' among people who are politically and socially disinherited. ${ }^{77}$ The last few decades have seen noteworthy demographic shifts as rural people have inceasingly headed for the cities. This has led to radical discontinuities in traditional ways of life. Robert Mapes Anderson notes that "Pentecostalism has played a role in easing the transit of some of those who have suffered most from the transformation of preindustrial societies into modern urbanizing, industrializing ones. ${ }^{78}$ In Religion, Altered States of Consciousness, and Social Change, Erika Bourguinon highlights the correlation between such practices and change:

... beyond the control of individuals are the frequently cataclysmic consequences of change-social, cultural, economic, and political. And when we consider the relationship of religion to change, its double role as a bulwark against change on the one hand and as a mediator or even initiator of change on the other, we often find that key individuals in this process experience altered states of consciousness. ${ }^{79}$

The ability of Pentecostal practices like glossolalia to encourage experiments in change, fostered by experiences of disinhibition, may help to explain why this fledgling Christian sect has grown so rapidly during this era of unprecedented globalization.

One of the hallmarks of the shift from a traditional, rural way of life to an urban, globalized one is an impoverishment of religious experiences. Speaking in tongues is foremost a sacred act which distinguishes itself from profane speech. It marks a Pentecostal gathering as a sacred time and place in the same way that the sacrament of communion does for Catholics: "Glossolalia, as a manifestation of the divine contributes a sacred note to a meeting, something it does much less frequently and to a

\footnotetext{
${ }^{76}$ Budden, Ashwin. "Pathologizing Possession: An Essay on Mind, Self, and Experience in Dissociation," 54.

77 Cox, Harvey Gallagher. Fire from Heaven, 315.

$7^{8}$ Anderson, Robert Mapes. "Pentecostalism," 7032.

79 Bourguignon, Erika. "Introduction," 4.
} 
lesser degree in private experiences. ${ }^{\text {"0 }}$ Glossolalia underscores the liminality that establishes the individual and collective, the sacred and profane. It serves as proof of God's presence while also establishing the ritual space for the group, an important feat for a religion which eschews the kind of ritual paraphernalia showcased in Catholic churches, for instance.

The most noteworthy aspect about belief in glossolia relates to its divine inspiration. It is, according to Pentecostals, a gift of the Holy Spirit which certifies one as truly baptized ${ }^{81}$ Moreover, the experience that glossolalia is 'unwilled,' that it erupts out of one's mouth without conscious intention, convinces the glossolalist that he is undergoing a sacred experience. As reviewed above, it would seem that downregulation in the circuits of the dorsolateral prefrontal cortex leads to a diminished sense of volition. This condition, either a cause of glossolalia, an effect of the practice, or, more likely, a dynamic interaction among learning, speech practice, sensory driving, and contextual priming, facilitates some of the peculiar experiential aspects of the ritual. With this diminished sense of volition, a 'dissociation' between the typical experiential correlates of speech occurs leading to an experience of the uncanny. The speech coming from the practitioner's mouth seems not his own; an 'intentional deficiency' has emerged so an inferential 'repair process' must follow. ${ }^{{ }_{2}}$ Through learning and cultural models, this leads to the ascription that the glossolalic speech is actually that of the Holy Spirit. Consider this earnest report by someone experiencing glossolalia for the first time:

I had been advised that if I wanted tongues, I ought to try to make sounds, so I did, thinking how stupid I would look later on; so I made a sound, and the gift was there, fullblown. I began immediately praying in tongues. It was for me a specific proof that I had received the Holy Spirit. It was detached from any emotionalism. It was something I knew I would be incapable of. Just to make a lot of syllables and make it seem like it were a language. That pace was too rapid and it did sound like sentences. It is continuing proof that regardless of what my own situation happens to be-that God is still operating in $\mathrm{me}^{83}$

${ }^{80}$ Samarin, William J. Tongues of Men and Angels, 215.

${ }^{81}$ Synan, Vinson. The Holiness-Pentecostal Tradition, 94.

${ }^{82}$ Lisdorf, Anders. "The Effect of Ritual Action on Evaluation of Credibility in Divination," 1.

${ }^{83}$ Harrison, Michael I. "Sources of Recruitment to Catholic Pentecostalism," 405-406. 
This experience happened by 'letting go,' by a disinhibition that is likely mediated by changes in the prefrontal cortex. But it would be folly to take this scientific description as an 'explanation' of the experience so vividly recounted above. One does not 'explain' the other; an improved understanding of the biology does not diminish the felt experience but neither does the experience exist in a world outside or 'above' nature, somehow bypassing (or surpassing) the person's culture, body, and brain.

Disinhibition serves as a requirement for crossing thresholds, for exploring and experimenting in the liminal state between ascribed roles, expectations, and understandings. ${ }^{84}$ Seen as a ritual practice that helps to transition between, and establish, meaningful oppositions - control/spontaneity, individual/group, and sacred/profane-speaking in tongues may be thought of as a bodily ritual that facilitates change. Reflecting the larger psychocultural themes of Pentecostalism, the ritual practice of glossolalia promotes an atmosphere of indeterminacy and openness. The practice, like the religion, addresses transitions between varied sociocultural configurations. This liminal behavior finds its neural correlate in the regulation of inhibition by the prefrontal cortex. The structure of consciousness can be understood as a fine balance between the impulses and activity of subcortical structures by the cultural proscriptions that have helped to mold the prefrontal cortex ${ }^{85}$ Culture and the body have shaped each other to establish an appropriate behavioral environment that includes careful balances between inhibition and disinhibition. Disinhibition serves as a prerequisite to speaking in tongues. In the same way that one must be disinhibited in order to dance spontaneously, so must the glossolalist refrain from any attempts to control the utterances that emerge. Rather, the person must - as in dancing — attempt to release oneself from the controlled nature of speech by allowing spontaneous utterances to flow from one's mouth. But in hearing alien words come out of one's mouth, there is an additional sense of the uncanny. This sense, coupled with the learning that accompanies it - that these are, in fact, the words of the Holy Spirit-marks glossolalia as a powerful religious experience; to engage in it is to allow one's speech to proceed in an inspired fashion. In this state the person finds some resolution, at least a transient one, of the opposites that frame each human life.

\footnotetext{
${ }^{84}$ Turner, Victor. The Forest of Symbols; Turner, Victor. The Ritual Process.

${ }_{55}$ Goldberg, Elkhonon. The Executive Brain, 139-156.
} 


\section{Attribution Theory and 'Experiences Deemed Religious'}

In pairing glossolalia and the transient hypofrontality hypothesis, a case study for the utility of the neuroscience of religious practice and experience is highlighted for critical examination. But to a larger question, what can the neuroscience of religious experience contribute to the overall study of religion? An answer to this question must attend to the theories of religious experience itself. As a category of study, religious experience has long been a contentious domain. A recent book, Religious Experience Reconsidered, by scholar Ann Taves, traces the history of these debates and takes bold steps towards reconciling them. Taves notes that a focus on experience in religion arose particularly in 19th century culture and philosophy. It was during this time that theorists began to put forth their ideas about the nature and significance of religious experience (and experience more generally). ${ }^{86}$

At the beginning of the 19th century, Friedrich Schleiermacher's description of religion as a 'feeling of absolute dependence' further shifted concerns away from institutions, doctrines, and practices while highlighting subjectivity and experience as the ultimate arbiters of the person's relationship with God. ${ }^{87}$ By the early 2oth century, religious experience had been thoroughly reified. Rudolf Otto, for instance, found the highest expression of piety in the sense of the mysterium tremendum, describing a feeling "sweeping like a gentle tide, pervading the mind with a tranquil mood of deepest worship ... it may burst in sudden eruption up from the depths of the soul with spasms and convulsions, or lead to the strangest excitements, to intoxicated frenzy, to transport, and to ecstasy." ${ }^{88} \mathrm{He}$ defined religious experience as a sui generis phenomenon "irreducible to any other; and therefore, like every absolutely primary and elementary datum, while it admits of being discussed, it cannot be strictly defined." ${ }^{\prime 9}$ Many scholars of religion followed this move, essentially setting religious experience aside as a category, an 'irreducible, primary datum.' But, as Taves notes, "... for most scholars, the claim that religion is sui generis is simply another way of saying that religion cannot or should not be explained in anything other than religious terms." ${ }^{\circ}$ This attitude has

\footnotetext{
${ }^{86}$ Jay, Martin. Songs of Experience.

${ }_{7}$ Schleiermacher, Friedrich. On Religion: Speeches to Its Cultured Despisers, 54.

${ }_{88}$ Otto, Rudolf. The Idea of the Holy, 12-13.

89 Ibid., 7.

9o Taves, Ann. Religious Experience Reconsidered, 18.
} 
undoubtedly slowed progress in the understanding of such experiences and prevented the kind of cross-disciplinary work that might shed further light on them.

In Religious Experience Reconsidered, Taves makes efforts to bridge some of these old divides. A key tool here is the use of attribution theory. Between an experience and subsequent interpretations of that experience lie the dynamic, culturally specific processes of meaning making. In social psychology, attribution theory typically refers to the way in which people make use of folk psychology to understand goals, desires, and intentions in human behavior. ${ }^{91}$ In short, attribution theory focuses on explanation of causes, especially causes of human behavior. Attribution theory is to human behavior what hermeneutics is to textual analysis.

Harold Kelley's covariation model, one of the primary attribution theories, posits that people are intuitive scientists..$^{92}$ That is, they engage in experiments in which a distinction is made between independent and dependent variables. For example, if a person picks up a sci-fi book in an airplane and finds it to be an enjoyable reading experience then the person might tentatively judge that she likes the genre, something she did not know about herself before. In this case, the response, "I like sci-fi," is the dependent variable and such potential causes as the genre, the author, or the context, are the independent variables. Subsequent 'experiments' might be performed; the person may read a set of well-known sci-fi books and determine that she does not really enjoy the genre. She may read other books by the same author and similarly discover her lack of interest. But upon finding herself in another plane with another discarded novel, this time with a suspense plot, she may infer that it was not the particular genre or author but the fact that 'escapist' literature helped her to get through an otherwise uncomfortable flight. So the belief 'I like to read escapist literature when taking flights' highlights the way in which the dependent variable covaries with the independent one.

Religious studies has made use of related psychological theories. Wayne Proudfoot and Phillip Shaver comment that "attribution theory would suggest that labelling and interpretation are fundamental to religious experience." ${ }^{93}$ According to their assessment, religious experience consists in having an experience and attributing religious significance to

\footnotetext{
${ }^{91}$ Krueger, Joachim I. “Attribution Theory.”

${ }_{92}$ Försterling, Friedrich. "Kelley's Covariation Model."

93 Proudfoot, Wayne and Shaver, Phillip. "Attribution Theory and the Psychology of Religion," 324.
} 
it. In Pentecostal glossolalia, both the experience of speech disinhibition and the attribution of the Holy Spirit to this experience are essential to the practice. Glossolalia emerges from numerous states, behaviors, and attributions. Experience, even religious experience, can be 'decomposed.' And in decomposing the experience and studying the interacting parts that go into it, scholars can refine their notions about such phenomena. While Taves significantly refines and extends these ideas, the gist of them, as related here, highlight how religious experience is not sui generis. The experience is deemed a 'religious experience' due to complex factors of attribution and ascription, not because of any quality unique unto itself (e.g. Otto's numinous), though it may seem that way to subjects.

Work by Nina Azari and colleagues on the neural correlates of religious experience also supports the attribution of meaning to those experiences deemed religious. She specifically addresses this point in a number of publications. ${ }^{94}$ Azari notes that "religious experience is a cognitively structured phenomenon for which thoughts and beliefs are central. ${ }^{{ }^{95}}$ An experience deemed religious is not mediated by any single 'God spot' in the brain, but is composed of numerous activations in distributed neural systems and, importantly, includes 'complex cognitive factors.' In one set of experiments, Azari and colleagues noted:

... religious experience and emotional states may be mediated by distinctive cognitive neural patterns, involving nonlimbic neocortical areas. The present network analysis suggests that what makes an experience distinctly religious - as opposed to nonreligious - involves complex cognitive factors, rather than an elementary pre-cognitive arousal response mediated by limbic processes. ${ }^{96}$

Azari's work suggests that religious experiences (or, more precisely, experiences people consider religious) cannot be stripped of the complex, culturally mediated judgments that shape them. In "Religious Experience and Emotion," Azari and colleagues assert that "... there is no pre-cognitive core to religious experience; the phenomenon is itself structured in terms of past and present beliefs, perceived meaning, and interpretation of the given experiential context." ${ }^{\prime 97}$ Thus, the neuroscientific work on religious

\footnotetext{
${ }_{94}$ Azari, N.P., et al. "Neural Correlates of Religious Experience"; Azari, Nina P. Religious Experience as Thinking that Feels Like Something; Azari, Nina P. "Neuroimaging Studies of Religious Experience: A Critical Review."

95 Azari, Nina P. "Neuroimaging Studies of Religious Experience: A Critical Review," 43.

${ }^{96}$ Azari, N.P., Missimer, J., Seitz, R.J. “Religious Experience and Emotion,” 276.

97 Ibid., 272.
} 
experience points toward increasing complexity. It is no longer legitimate to insulate experience from scientific study nor to assign it sui generis status. Just as neural networks suggest the emergence of behavior from complex and varied systems, so does experience, religious or otherwise, seem to arise from bodily states in association with cognitive judgments. The magic occurs at the intersection of such varied components rather than in any single nucleus.

Taves has concluded that religious experience should not be treated, or studied, as something unique and privileged unto itself. All human experience should be studied by whatever tools, methods, and theories may shed light upon it. To set aside religious experience is to handicap the possible understandings scholars may reach. To privilege subjective experience, to describe it as a phenomenon knowable only on its own terms, is to commit the same fallacy as those 19th century theorists who asserted that life arises from an élan vital, or some other essence irreducible to scientific analysis. The 2oth century would bring us a refined understanding of the individual processes that undergird life: DNA, protein transcription, the Kreb's cycle, and all the rest. ${ }^{9}$ The 'problem of life,' it would seem, was no single problem after all; an alternative ontology was ultimately unnecessary. Rather, life turned out to be an emergent phenomenon composed of the many lesser, more tractable phenomena scientists had become expert in studying. If people are disenchanted by this scientific, building-block approach then more work needs to be done to determine what leads people to place so much value on the unknown and the purportedly unknowable.

The aim of this chapter is to highlight that all relevant tools for the study of religion ought to be pursued. Those who would decry reductionism are more often than not expressing a proclivity rather than a necessity for their particular research methods. There is no longer an unassailable wall between science and human experience. The current state of affairs may finally allow a set of bridges to be built between these too often divided spheres of human inquiry.

\footnotetext{
${ }^{8}$ Churchland, Patricia Smith. Neurophilosophy, 278-294.
} 



\title{
SYNCHRONIZED RITUAL BEHAVIOR: RELIGION, COGNITION AND THE DYNAMICS OF EMBODIMENT
}

\author{
Sebastian Schüler
}

\begin{abstract}
Our bodies, and our felt experiences of our bodies in action, finally take center stage in the empirical study of perception, cognition, and language and in cognitive science's theoretical accounts of human behavior. ${ }^{1}$
\end{abstract}

Synchronic behavior seems to happen naturally wherever individuals gather in groups and start to interact with their bodies. Bodily synchronization can be found in all kinds of social behavior, such as the vibrant movements of a school of fish, the energetic formations of a flock of birds, in a crowd at a music concert, or at a charismatic ritual performance. Its coordinating effects on the body underlie such diverse actions as the marching of soldiers, the dancing of a couple, the applause of an audience, the singing of a choir, or the collective muttering of prayers.

In this chapter I will, first, argue for the significant role of synchronic behavior in forming religious rituals, and explore the underlying cognitive and embodied mechanisms that drive such synchronizing processes in bodily interactions. Secondly, while critically reflecting on the scientific study of religion, cognition, and the body, I will emphasize that current cognitive and evolutionary theories of religion have focused too much on the brain in order to explain religious thought. Thereby they have neglected the body and its effects on both cognitive processes and embodied religious behavior. Thirdly, I will introduce an alternative approach from a lesser known field in cognitive science called embodied cognition that has not received much attention in the study of religion yet and that challenges the traditional mind-body dualism. Finally, I will elaborate on the embodied cognition model by sketching out a so-called body-schema of synchronized ritual behavior that can serve as an integrative model in the study of religion and the body.

${ }^{1}$ Gibbs, Raymond W., Jr. Embodiment and Cognitive Science. Cambridge: Cambridge University Press, 2006, 13. 
The thesis of this chapter is that the shift toward neurobiological explanations of religion in religious studies has led to the situation that embodied practices and experience are largely ignored. Modern neuroscience by and large favors concepts of a naturalized body over aspects of human embodiment that can highlight the interdependent relations between the brain, the body, and the social world. From this perspective, the concept of embodied synchronization can help us to negotiate between a too naturalized perspective on the body and religion on the one hand, and a vague phenomenology of embodiment on the other hand that lacks neurobiological insights. I therefore start from the assumption that it the embodiment of ritual practice, emotions, movement, dynamic bodily interactions, and social representations that shape the way we perceive the world and act in it. It is the bodily implication on human culture and its role in everyday social interaction that deserves new attention, particularly for a critical debate on modern neuroscience.

\section{Embodied Synchronization as Integrative Model for the Scientific Study of Religion and Ritual}

Human cultures and societies are in large parts coordinated and structured by synchronizing rituals such as annual celebrations, rites of passage, daily mealtimes, high holy days and holidays, and other everyday rituals. ${ }^{2}$ In addition, human beings are the only living species which is able to synchronously move to rhythmic music. ${ }^{3}$ Sociologist Robert Bellah, for instance, pointed out: “This ability to 'keep together in time' is probably one of several biological developments that have evolved synchronously with the development of culture, but one of great importance for the ritual roots of society." 4 This kind of synchronous behavior was recognized as a core social mechanism already a hundred years ago by the famous sociologist of religion Émile Durkheim, whose notion of "collective effervescence" pinpoints these emerging effects in highly emotional religious

\footnotetext{
${ }^{2}$ McNeill, William H. Keeping together in time: Dance and drill in human history. Cambridge, Mass.: Harvard University Press, 1995; Rappaport, Roy A. Ritual and Religion in the Making of Humanity. Cambridge: Cambridge University Press, 1999.

3 Merker, Björn. "Synchronous Chorusing and Human Origins." In The Origins of Music, edited by N.L. Wallin, B. Merker, S. Brown, 315-27. Cambridge, MA: MIT Press, 2000.

4 Bellah, Robert N. "Durkheim and Ritual." In The Robert Bellah Reader, eds. Robert N. Bellah and Steven M. Tipton, 150-80. Durham and London: Duke University Press, 2006, 161.
} 
rituals. ${ }^{5}$ In addition, his nephew, the sociologist Marcel Mauss, emphasized that by even observing a dance one can easily notice that heartbeat, breath, and muscle movements of individuals start to correspond and that these effects seem to lie at the intersection of the social and the physiological rather than at just the social and the psychological. ${ }^{6}$

Even though in modern neuroscience the emphasis still lies on the psychological parts of human behavior rather than on the social or embodied parts, these effects of interactive synchronization and coordination have also caught the attention of neuroscientists who have investigated the cognitive and neural mechanisms that underlie synchronous clapping or the neural synchrony of musicians. ${ }^{7}$ Thus, synchronization processes are naturally emerging mechanisms that coordinate different activities such as neural networks, bodily movements, or social organization.

What these studies do not answer is how synchronicity actually emerges through bodily interaction and, in return, what effects it has on our brains and bodies? Do people embody a particular body-schema while interacting with their bodies? And if so, how do such body-schemas unconsciously drive the dynamics of social interactions? What role does this embodied synchronization play in religious rituals and what insights can cognitive science offer here?

These synchronizing effects of our bodies in action, which can be found from dyadic to group interactions, are constitutive of social behavior in general and religious rituals in particular. The dynamics of social synchronization can cause a particular collective behavior or a collective effervescence that cannot be reduced to individual psychological capacities alone. Driven by the mutually enforcing dynamic of bodily interactions, people often change their behavior and begin to act in favor of the group rather than according to their own beliefs or reasons. As Maurice Bloch emphasized:

One enters a ritual mode of communication by radical modifications of ordinary behavior... One often synchronizes one's bodily and linguistic movements with those of others. This is so to the extent that one is not sure

${ }^{5}$ Durkheim, Émile. The Elementary Forms of Religious Life. New York: Free Press, 1965.

${ }^{6}$ Mauss, Marcel. "Techniques of the Body." In Marcel Mauss, Techniques, Technology, and Civilisation, edited and introduced by Nathan Schlanger, $77-96$. New York and Oxford: Durkheim Press/Berghahn Books, 2006.

7 Neda, Zoltan, E. Ravasz, Y. Brechet, T. Vicsek, A.L. Barabasi. "The sound of many hands clapping: Tumultuous applause can transform itself into waves of synchronized clapping." Nature 403 (2000): 849-50. 
whether it is oneself or another inside oneself who is acting and using one's voice and one's body. ${ }^{8}$

It is exactly this phenomenon of collective synchronization and its impact on individual behavior and experience that interests us here.

Such effects of collective effervescence were also sometimes characterized as group-hysteria and thereby often disregarded as emotionally laden or irrational behavior. Social studies of religion have too often neglected the transformative influence such effects have on the perception and bodily states of ritual participants. Sociologist Randall Collins highlighted this aspect by stating: "Part of the collective effervescence of a highly focused, emotionally entrained interaction is apportioned to the individuals, who come away from the situation carrying the group-aroused emotion for a time in their bodies."

The emerging collective effervescence can be seen as a social phenomenon that occurs in many group activities and serves as a driving force for social cohesion and even for social change. Bodily synchronization appears to be an important somatic disposition for this emergence of collective effervescence in rituals. For that reason, it is the relation between these two sides of human behavior that need further attention: the nature of bodily implications on social interaction, and the nature of social implications on embodied interaction. The concept of synchronized ritual behavior therefore draws on the intersection of social and bodily interactions and their underlying cognitive and somatic dispositions. As a result, this chapter calls for the bodily and cognitive implications of collective synchronization as parts of a natural social behavior. Synchronization-in a broad sense - can best be understood as the ways our brains and bodies effectively form embodied interactions. It is thus of great interest to consider the mutual interrelations and affections of the natural and the social body.

In order to avoid a strict dichotomy between the natural and the social body, or the body and the brain, I argue for an integrative model of embodiment including embodied cognition. Embodiment, also a central analytical key concept for the study of religion, was often taken as a unidirectional explanation for the individual incorporation of the social

\footnotetext{
${ }^{8}$ Bloch, Maurice. “Are religious beliefs counter-intuitive?" In Radical Interpretation in Religion, ed. Nancy K. Frankenberry, 129-46. Cambridge, MA: Cambridge University Press, 2002, 142.

${ }^{9}$ Collins, Randall. Interaction Ritual Chains. Princeton and Oxford: Princeton University Press, 2004, xii.
} 
(see the notion of the habitus in Pierre Bourdieu), ${ }^{10}$ rather than a dynamic, reciprocal, or synchronous process of bodies in interaction. From the latter perspective, human embodiment appears not to be a mediator between two ontologically incommensurable worlds, namely of the social and the natural body, but serves as an integrative model that starts from the assumption that bodily interactions constitute permanent processes of embodiment, and in this way shape human agency and the ways humans perceive and act toward the world around them. By focusing on cognitive and somatic mechanisms as well as the sensory and emotional perception and experience that underlie processes of embodied synchronization, I aim to outline an integrative model of human embodiment that plays a major role in shaping ritual interaction. This understanding of embodiment is critical to positivistic and naturalized concepts of cognition and the body in current scientific approaches to religion, as will be discussed in the following section.

\section{Scientific Reflections: Religion, Cognition, and the Body}

The shift during the last three decades toward cognitive sciences and neurobiology has created new academic and public interest in the neurological and evolutionary foundations of human culture in general and religious behavior in particular. This new attention to the neural mechanisms of the human mind has made a great contribution to our understanding of human culture and religion. As religious behavior is a significant element of all cultures throughout human history," and as cognitive sciences assume universal similarities in cognitive processes, they can offer new insights into the universal cognitive mechanisms involved in the emergence and transmission of religious representations. ${ }^{12}$

${ }^{10}$ Bourdieu, Pierre. Outline of a Theory of Practice. Cambridge: Cambridge University Press, 1977.

"The problem of defining religion has been discussed in the study of religion for a long time without finding a proper solution (see Fitzgerald, Timothy. The Ideology of Religious Studies. Oxford, New York: Oxford University Press, 2000). Also stating that religion is a cross-cultural phenomenon certainly implies a western perspective of what is assumed to be religious. But this is not the place for solving these problems and a working definition of religion as a specific cultural expression including certain believe-systems can be applied here for analytical purposes.

${ }^{12}$ Boyer, Pascal. Religion Explained. The evolutionary origins of religious thought. New York: Basic Books, 2001. Atran, Scott. In Gods We Trust: The Evolutionary Landscape of Religion. Oxford, New York: Oxford University Press, 2002. Barrett, Justin L. Why Would Anyone Believe in God? Walnut Creek: Alta Mira Press, 2004. 
The cognitive and evolutionary explanation of religion is a recent attempt to introduce a naturalistic program into the classic domain of humanities. But even though this endeavor stands for a strong scientific approach that highlights scientific explanations over social descriptions, it has lead to contradictory results. Some scholars of this new paradigm see religion as a cognitive by-product in human evolution..$^{13}$ Others, also drawing on a naturalistic approach, explain religion as a cognitive adaptation with certain advantages for human cultural evolution. ${ }^{14}$ Although both theoretical approaches fruitfully challenge the intersection of nature and culture, they still leave some questions open. Cognitive explanations have too often reduced religion to cognition, and cognition to neural activity, and as a result by and large neglected the body. ${ }^{15}$ Accordingly, modern cognitive and evolutionary scholars of religion have overestimated the naturalist account as a new scientific paradigm and consistent methodological approach. ${ }^{16}$ The adaptation of cognitive and evolutionary theories for explaining social, cultural, and religious behavior is not only a question of scientific accuracy but also a normative question of whether we want to take evolutionary theories as imperative models of interpretation for our social life, as David Sloan Wilson suggested. ${ }^{17}$ This kind of naturalistic program in the study of religion - if taken as the only or better way to do science-is itself an ontology or worldview. ${ }^{18}$ Instead—and from a more modest point of view-it would better count as a pragmatic-hypothetical

${ }^{13}$ Boyer, Religion Explained; Barrett, Why Would Anyone Believe in God?

${ }^{14}$ Sosis, Richard. "The Adaptationist-Byproduct Debate on the Evolution of Religion: Five Misunderstandings of the Adaptationist Program." Journal of Cognition and Culture 9, no. 3 (2009): $315^{-32}$.

${ }^{15}$ For an exception see Barsalou, Lawrence W., Aron K. Barbey, W. Kyle Simmons, Ava Santos. "Embodiment in Religious Knowledge." Journal of Cognition and Culture 5, no. 1-2 (2005): 14-57. For a probably new development in the evolutionary study of religion, cooperation, and bodily effects see Bulbulia, Joseph and Marcus Frean. "The Evolution of Charismatic Cultures." Method and Theory in the Study of Religion 22, no. 4 (2010): 254-71. See also Konvalinka, Ivana, Dimitris Xygalatas, Joseph Bulbulia, Uffe Schjodt, Else-Marie Jegindo, Sebastian Wallot, Guy Van Orden, Andreas Roepstorff. "Synchronized arousal between performers and related spectators in a fire-walking ritual." PNAS 108, no. 20 (2011): 8514-19.

${ }^{16}$ Slingerland, Edward. What Science Offers the Humanities: Integrating Body and Culture. Cambridge: Cambridge University Press, 2008. Slingerland, Edward. "Who's Afraid of Reductionism? The Study of Religion in the Age of Cognitive Science." Journal of the American Academy of Religion 76, no. 2 (2008): 375-411.

${ }^{17}$ Wilson, David Sloan. Evolution for everyone. New York: Delta Trades Paperbacks, 2007 .

${ }^{18}$ Herrnstein-Smith, Barbara. Natural Reflections: Human Cogniton at the Nexus of Science and Religion. New Haven and London: Yale University Press, 2009. 
approach, one for which we do not yet know what kind of new insights it will bring for our understanding of cultures, societies, and religions.

Furthermore, this attempt to explain religion on the basis of cognitive science can be seen as a lopsided endeavor if reduced to cognitive and evolutionary explanations alone. One core problem is a single-sided emphasis on cognitive and neural mechanisms and their underlying functions for mental representations. Evolutionary psychology has taken center stage for most explanations within cognitive sciences. The well-known sentence from biologist Theodosius Dobzhansky that 'nothing in biology makes sense, except in the light of evolution' more than ever represents a guiding paradigm in biology and cognitive science, and additionally has become a central key in the study of culture and religion.

The current popular interest in natural explanations of human behavior can therefore be comprehended as an aspiration for positivistic grounded knowledge in order to be able to give explanations to uncertainties in life. This of course also bears the dangers of popular simplistic explanations such as 'why men can't listen and women can't read maps' ${ }^{19}$ which often derive from a naïve application of evolutionary psychology according to which behavioral differences were biologically set during the Stone Age period. ${ }^{20}$

But it is one thing to explain the emergence of culture or religion as a causal consequence of the evolution of human brain functioning, and another one to highlight the mutual influences of particular cognitive abilities, embodied action, and socio-cultural patterns as evolved human properties. In the light of social cognitive neuroscience, for instance, some scholars

remain unconvinced that cultural evolution is merely a continuation of natural evolution with other means, and that cultures evolve primarily as mechanisms for maximizing Darwinian fitness of their members or even of their genes. There are more 'optimization criteria' for cultural evolution than reproductive success. ${ }^{21}$

${ }_{19}$ Pease, Allan and Barbara Pease. Why Men Don't Listen \& Women Can't Read Maps. London: Orion Books, 2001.

${ }^{20}$ This can count as a standard argument in evolutionary psychology according to which our 'modern skulls house a Stone Age mind.' See Tooby, John and Leda Cosmides. "The Psychological Foundations of Culture." In The Adapted Mind: Evolutionary Psychology and the Generation of Culture, ed. Jerome Barkow, Leda Cosmides, John Tooby, 19-136. New York and Oxford: Oxford University Press, 1992, 85.

${ }^{21}$ Markl, Hubert (ed.). The Evolution of Social Behavior. Hypotheses and Empirical Tests. Weinheim: Verlag Chemie, 1980, 8. 
Considering such approaches from the perspectives of social and embodied cognition and social neuroscience ${ }^{22}$ it is important to draw attention to a problem in cognitive theories of religion that has not yet been well addressed, namely the mutual influences of brain, body, and social world.

Certainly one could argue critically that a perspective that considers this mutual relationship between brain, body, and the social world assumes an ontological separation of those concepts and therefore suffers from a Cartesian dualism. Indeed, the persistency of this dualism, which can be understood as a legacy of western Protestantism, ${ }^{23}$ still remains in western scientific discourse and constitutes modern social and cognitive theorizing of body-mind relations. In fact, this dualism is wrong: the mind is as much a part of the brain as the other way around and the same is true for the body and the brain as two distinguishable but inseparable parts.

Although the Cartesian model is flawed, it is still fruitful to explore the relationship between mind, body, and culture, albeit with some modifications. Rather than starting from a classical dichotomy between mind and body, we should model our theories of the 'embodied mind' according to its complexity in relation to the social world. ${ }^{24}$ Such an interactive model is instructive for theorizing the relations between religion and the body, and enables us to expand current, somehow lopsided attempts in applying cognitive and neurobiological theories to the study of religion.

As a matter of fact, scholars in the cognitive study of religion still make use of a computational model of the brain, following Noam Chomsky's initial idea of innate cognitive modules. ${ }^{25}$ According to this model, the human brain is seen as an information processing organ with underlying hardwired neural mechanisms, which determine our mental capacities, and which are assumed to be responsible for the emergence of cultural and religious phenomena. Although this model of the brain is useful for explaining the emergence and transmission of mental representations in religions, it has little to do with the body. Besides, it is also not the only model of cognition available in the attempt to explain religious

\footnotetext{
${ }^{22}$ Morsella, Ezequiel, John A. Bargh, Peter M. Gollwitzer. Oxford Handbook of Human Action. Oxford, New York: Oxford University Press, 2009.

${ }^{23}$ See Mellor, Philip A., Chris Shilling. Re-forming the body. London: Sage, 1997, 10.

${ }^{24}$ Clark, Andy. "Where Brain, Body and World Collide." Daedalus:Journal of the American Academy of Arts and Sciences (Special Issue on the Brain) 127, no. 2 (1998): 257-80.

${ }_{25}$ Slingerland, What Science Offers the Humanities. Boyer, Religion Explained. Barrett, Why Would Anyone Believe in God?
} 
behavior. As a matter of fact, there exists no cognitive meta-theory for explaining how the brain works. Rather, we have different, sometimes contradictory models of the brain and its underlying functions. ${ }^{26} \mathrm{~A}$ different model of the brain that I would like to note here points much more toward the embodied experience of bodily interactions. This approach suggests that instead of neural modules, sensory perception and bodily interaction is shaping, or better, is embodying cognition and particular forms of behavior. ${ }^{27}$

At the center of these relations certainly lies the significance of experience, which was already highlighted by the philosopher John Locke as the central phenomenon by which we gain all our knowledge, ideas, and skills. It is exactly this real-world experience that shapes our brains and incorporates an idea of the world: "we do not first conceptually map the universe and then act in it and experience it, but the other way round. ${ }^{228}$ Neurobiology has offered new insights into the neurobiological substrate of experience. And scholars of religion have given different interpretations to these findings. Indeed, it might be very exciting to use brain scan methods to catch the neural activity of a religious person during a religious experience or in a moment of deep contemplation. ${ }^{29}$ However, what is made visible with such methods is brain activity, not religious experience; in the end it is the religious person who defines his/her experience as religious. ${ }^{30}$

Experience and sensation play major roles in our understanding of the human brain, and it is important not to downgrade experience to mere neural activity, of which the computational model of the brain is guilty. ${ }^{31}$ However, in considering sensory and emotional states of the body we need more than brain scans or reductionist explanations-what we need are integrative models of embodiment that allow us to reflect upon the 'total human,' as Marcel Mauss put it in his famous contribution on "the techniques of the body." ${ }^{32}$ The challenge is therefore to develop a

\footnotetext{
${ }^{26}$ Freeman, Walter. How Brains Make Up Their Minds. London: Phoenix House, 2000.

${ }^{27}$ For a similar approach to religious emotion see Riis, Ole and Linda Woodhead. A Sociology of Religious Emotion. Oxford, New York: Oxford University Press, 2010.

${ }^{28}$ Riis and Woodhead, A Sociology of Religious Emotion, 4.

${ }^{29}$ Newberg, Andrew, Eugene D'Aquili, Vince Rause. Why God won't go away: Brain science and the biology of belief. New York: Ballantine Books, 2001.

$3^{0}$ Taves, Ann. Religious Experience Reconsidered: A Building-Block Approach to the Study of Religion and Other Special Things. Princeton: Princeton University Press, 2009.

${ }^{31}$ Slingerland, What Science Offers the Humanities, 392.

$3^{2}$ Mauss, "Techniques of the Body".
} 
conceptual framework in order to theorize the relations between the natural and social body and to gather ground for embodiment rather than to explain body-mind relations in favor of one or the other. ${ }^{33}$

\section{The Brain's Flexibility and the Embodiment of Ritual Experience}

Even though cognitive and evolutionary approaches have given challenging explanations for the acquisition and transmission of religious representations and rituals, yet the constitutive roles of dynamic interaction and embodied experience for religious rituals remain underrepresented. Although religious representations and ritual action may to a certain extent be constrained by cognitive mechanisms of the brain shaped through evolution, ${ }^{34}$ religion is not only about religious representations such as gods or ghosts. Also, bodily actions constitute religious and ritual life and must therefore be taken seriously in cognitive theories of religion. This is confirmed by recent models in embodied cognitive science, which have demonstrated that cognitive processes are shaped not only by evolution but also by cultural influences and that cognition can be seen as grounded and situated in social and bodily contexts..$^{35}$

Brains are not determined by cognitive modules. They are, however, more flexible than we sometimes assume. Physiological changes occur in our brains during exposure to practice routines and learning tasks; these changes entail functional and structural transformations in brain tissue, which demonstrate the brain's plasticity and how brain structures can be modified as a function of training, effort, and application of cognitive strategies. ${ }^{36}$ Moreover, the brain is capable of compensating for physiological

\footnotetext{
${ }_{33}$ Gallagher, Shaun. How the body shapes the mind. Oxford: Oxford University Press, 2005 .

${ }^{34}$ According to central theories within the Cognitive Science of Religion, most cognitive mechanisms consist of neurologically hard-wired so-called 'domain-specific' modules which are responsible for the acquisition and distribution of cognitive representations. See Boyer, Pascal and H. Clark Barrett. "Domain Specificity and Intuitive Ontology." In The Handbook of Evolutionary Psychology, ed. David M. Buss, 96-118. Hoboken, NJ: John Wiley \& Sons, 2005 .

${ }_{35}$ Gibbs, Embodiment and Cognitive Science. Smith, Eliot R. "Social relationships and groups: New insights on embodied and distributed cognition." Cognitive Systems Research 9, no. 1-2 (2008): 24-32. Gallagher, Shaun. "The Practice of Mind: Theory, simulation, or primary interaction?" Journal of Consciousness Studies 8, no. 5-7 (2001): 83-108. Freeman, How Brains Make Up Their Minds.

${ }^{36}$ Maguire, Eleanor A., Katherine Woollett, Hugo J. Spiers. "London taxi drivers and bus drivers: A structural MRI and neuropsychological analysis." Hippocampus 16, no. 12 (2006): 1091-101.
} 
damage, adapting other brain areas for certain tasks. Particularly during skills acquisition, human brains go through a dramatic series of functional and structural changes in the way information is processed. In other words, we educate our brains, feelings, and behavior through physiological and cognitive effort in relation to our social and physical environment. The transmission of ritual action, for instance, goes along with the education of the body and the transformation of brain states (neural networks) by means of ritual performance. Therefore, bodies and our bodies in action can count as useful utilities for educating our brains. As Rebecca Sachs Norris pointed out:

Repetition, imitation, and the use of images in learning prayer or other rituals facilitate ever changing and deepening experience through plasticity and the creation of new related stimuli. Sacred images depicting specific postures or gestures associated with corresponding feelings can be and have been used not only to evoke feelings but also to educate the feeling toward certain experiences. ${ }^{37}$

Norris furthermore emphasizes that "[t]aking a position with the body affects the worshipper even more strongly than receiving a visual impression." ${ }^{\prime 8}$ Through bodily activities in ritual performance emotions can be 'refelt,' which leads to cultivation and collective embodiment of emotions for ritual purposes. Accordingly, Norris states:

That emotion can be refelt in the present when it is recalled enables religious feelings to be layered and developed, because each time a ritual gesture is repeated the emotion is recalled and new emotional memories laid down in association with the old ones to be recalled the next time. ${ }^{39}$

Similar to Norris' observations in religious rituals, neurobiologist Walter Freeman found evidence for such individually acquired and layered experience in his work on the odor perception of rabbits. Experiments have shown that each time the rabbits learned to recognize a smell their brains produced a new map for that particular perception. ${ }^{40}$ These cognitive 'maps' are not representations of odorants, because it is impossible to match each existing stimuli with a specific brain state as though the brain

\footnotetext{
${ }_{37}$ Norris, Rebecca Sachs. "Examining the Structure and Role of Emotion: Contributions of Neurobiology to the Study of Embodied Religious Experience." Zygon:Journal of Religion \& Science 40, no. 1 (2005), 195.

${ }^{8}$ Ibid., 190.

39 Ibid., 192-3.

${ }^{40}$ Freeman, Walter. "The physiology of perception." Scientific American 264 (1991): 78-87.
} 
were a computer program containing a set of smells. Instead "the patterns are unique to the history of the animal, because of its past experiences." ${ }^{41}$ The process of perception in terms of mapping the world onto our neural circuits is not so much a replication of the world in the mind but a creative process of individual experience producing individual cognitive maps. Consequently, says Freeman, "An act of perception is not the copying of an incoming stimulus. It is a step in a trajectory by which brains grow, reorganize themselves, and reach into their environment to change it to their own advantage." ${ }^{n 2}$

In the case of rituals we find many characteristic positions of the body such as lifting up arms, bowing, kneeling, dancing, and so on. Some people shake in the rhythm of the music or perform particular hand movements. Every ritual practitioner has typical postures with which he or she feels comfortable and which express certain feelings. Practicing and recalling these postures frequently helps the believer to intensify and re-enforce the characteristic feelings. The embodied experience then becomes part of one's own bodily awareness and perception. Moreover, the process of embodiment in ritual practice offers the practitioner "embodied orientations to self and world." ${ }^{43}$

\section{Bodies in Action: Tracing the Dynamics of Embodiment}

As already indicated in the previous paragraph, hardwired neural modules represent only one possible model for explaining cognition. The plasticity of the brain and the embodiment of particular bodily states, movements, and feelings can count as an alternative model that highlights the mind's rootedness in social contexts and its adaptability to social action. ${ }^{44}$ A dynamic understanding of social and embodied cognition starts from the assumption that cognitive processes require significant input from our bodies. Gibbs therefore criticizes standard cognitive models of the brain for their lack of evaluating bodily implications:

Cognitive psychologists, like many philosophers, often fail to recognize the significance of embodied action in the study of human mental life. Most

\footnotetext{
${ }^{41}$ Gibbs, Embodiment and Cognitive Science, 48.

${ }^{42}$ Freeman, "The physiology of perception", 85 .

43 Mellor, Philip A., Chris Shilling. "Body pedadogics and religious habitus: A new direction for the sociological study of religion." Religion 40, no. 1 (2010), 28.

${ }_{44}$ Freeman, How Brains Make Up Their Minds.
} 
experimental investigations of perception and cognition occur in laboratory situations where a person passively observes stimuli and then responds in some specific manner to what has been presented. In some instances, the person is physically restricted in his or her movements... Cognitive processes, especially, are viewed as strictly mental phenomena that have little to do with embodied experience. ${ }^{45}$

Gibbs words show that embodied experience has to be seen as a cognitive and as a somatic issue. This includes corporal contact as well as every kind of aesthetic and somatic perception. Music, for instance, or the sound of voices, odors, flavors, and savors, not to mention every form of body movement, gestures, and facial expressions all are forms of sensory perception that are perceived intensively in ritual interactions and shape the embodied experience of our own bodies in action and of those bodies with whom we interact.

Rituals with high charismatic and ecstatic stimulation are more likely to be performed in dense, energetic groups where people perceive and interact with each other intensively. In such socially intense situations the bodies of other ritual participants represent not just consciously perceived cognitive information such as the quantity of the bodies or the constitution of the group. Others' bodies are also sources of embodied experience that unconsciously influence the way we interact and synchronize with each other through shared somatic and emotional states of arousal.

Posture-one's own as well as that of other ritual participants-is especially important. Gibbs emphasized a strong "connection between the mental representation of posture, the movement of one's own body, and the perception of posture and movement of other bodies." ${ }^{26}$ While watching others performing actions with their bodies, the same body images and body movements tend to arise in the observer, also triggering similar mental representations and meanings. As the action of one person can become a stimulus for the actions of another person, bodily and cognitive synchronizations can occur. Just like in the wordless coordination of movements of a dancing couple, synchronicity in ritual interaction rests on ongoing action-perception loops, which drive the interaction and shape the embodied experience of the ritual participants.

According to the Italian neurobiologist Vittorio Gallese, we should even be wary of proposing strict dichotomies between action and perception.

45 Gibbs, Embodiment and Cognitive Science, 6.

46 Ibid., 35. 
He has shown that on a neural level "sensory pathways that... receive information from the so-called 'external world', share the same code with motor pathways that... activate neuro-muscular junctions that, in turn, determine our movements. ${ }^{47}$ The elements that connect action and perception Gallese calls mirror neurons, and explains these thus: When one watches someone cry, laugh, or get punched, one can almost feel the same sadness, joy, or pain that person experiences. The reason is that by watching bodily or emotional expressions mirror-neurons are activated that trigger similar somatic and cognitive states in the brain and body of the observer. Most of the human ability for empathy is based on the function of mirror-neurons. Although perception includes more than just visual stimuli and mirror neurons alone cannot fully explain embodied experience and interaction, both can highlight some of the neurobiological implications of empathetic abilities that are so important in ritual interaction.

Thus we have seen that the process of embodiment in social interaction rests on certain neural dispositions that mirror and simulate the actions of other persons in our brains and bodies. To be able to further develop an integrative model of dynamic embodiment, the synchronizing effects and dynamics that drive ritual interaction also need to be emphasized-a lacuna in embodied cognition researches, which have mainly focused on individual cognitive processes. As Eliot R. Smith critically notes:

Research regarding embodiment in psychology and cognitive science has generally focused on implications of embodiment for individual-level functioning - for example, on the role of sensory-motor systems in mental representations. But embodied cues also contribute to relational functioning-linking the perceiver to other people-and thereby influence a broad array of social/relational processes, such as liking, interpersonal coordination, and prosocial behavior. ${ }^{4}$

In order to understand better the synchronizing effects which arise in collective interaction, and to show how these dynamics facilitate ritual behavior, it is of great importance to connect the concept of embodiment with insights of social neuroscience and a dynamic approach to cognition. We gain further ground for an integrative approach to embodiment when rather than focusing only on individual psychological factors of embodi-

${ }^{47}$ Gallese, Vittorio. "The Inner Sense of Action. Agency and Motor Representations." Journal of Consciousness Studies 7, no. 10 (2000), 25, emphasis in original.

${ }^{48}$ Smith, "Social relationships and groups", 24. 
ment, we strengthen the emerging dynamics of bodies in action. For that reason it is helpful to distinguish between the implications of a bodyimage and a body-schema on embodied ritual interaction.

\section{From Body-Image to Body-Schema to Embodied-Meaning}

In order to successfully transmit and acquire rituals, their performance must be collectively shared and embodied. Whereas we know that ritual texts can transmit rituals over time, bodily performance also makes rituals alive and emotionally accessible, which in and of itself has an important transmitting role. The collective interaction in rituals unifies the practitioners emotionally and ties them into a ritual-group. Usually ritual practitioners possess a certain body-image for their ritual performance. They are able to perform a ritual, such as a prayer, by means of their learned capability to feel and access their own bodies.

It should be stressed that the embodied experience of a ritual is not only the outcome of individual body practices. It is also shaped through bodies in action, which, by synchronizing with each other, create a certain ritual dynamic. In order to explain the emerging dynamics of synchronization and the implied process of embodiment, it is useful to conceptually distinguish between a body-image and a body-schema. A conceptual framework of how such a body-schema works could offer new insights into the complex and dynamic interrelations between body, mind, and social environment and would not be restricted to symbolic forms and images of the body.

An interesting body-schema model has been developed by Shaun Gallagher. In his extensive work on embodiment, Gallagher has made a clear distinction between a body-image and a body-schema. He defines a body-image as "a system of (sometimes conscious) perceptions, attitudes, and beliefs pertaining to one's own body." A body-schema, on the other hand, can be defined as "a nonconscious system of processes that constantly regulate posture and movement." 49 Adding a dynamic approach to the concept of body-schema leads to the question of how bodyschemas are shaped and embodied through social interactions. As

49 Gallagher, Shaun. "Dynamic models of body schematic processes." In Body Image and Body Schema: Interdisciplinary Perspectives on the Body, ed. Helena De Preester and Veroniek Knockaert, 233-52. Amsterdam, Philadelphia: John Benjamins Publishing Company, 2005, 234 . 
Gallagher points out, learning how to dance, for instance, first requires a body-image that helps us to make sense of the movements of our own bodies. In the process of practicing, these movements become embodied and thereby a part of the body-schema which almost unconsciously coordinates the movements. ${ }^{50}$ The body then seems to dance on its own and even does so in coordination with a partner who partly becomes an extension of the body. As such, the body-schema of dancing has to be embodied through movement and interaction. Visual impressions or abstract explanations alone would not make someone a dancer. Even practicing certain dance movements all alone does not guarantee being able to dance with someone else. On the contrary, couples improve their dancing skills by dancing with the same partner over and over again. The same goes for developing a feeling for driving a particular car. A body-schema does not consist only of the learned and embodied movements of one's own body, but also correlates to the particular movements and sensory reactions of someone (or something) else.

Synchronized movements therefore are a central characteristic for the incorporation of a body-schema. This body-schema then structures our movements and the way we perceive the world. ${ }^{51}$ The body-schema is also responsible for the ways of sense-making and acting in the world. Conceptualizing such a body-schema refers to the fact of being a body rather than owning one. And being a body also implies enacting socially and synchronizing with other bodies. That is why a body-schema is not just 'embrained' or neurally realized-it is also embodied. It is created through body movements and therefore part of the soma, the muscles, nerves, emotions, sensory perceptions and correlated affective body states.

A similar model of embodiment can be found in the works of anthropologist Thomas Csordas when he speaks about 'somatic modes of attention.' According to Csordas, "one is paying attention with one's body" to oneself and to others, and therefore attention "refers both to attending 'with' and attending 'to' the body." ${ }^{22}$ Csordas' notion of 'bodily attention' is a useful concept for explaining ritual synchronization, because the occurring collective effervescence in rituals induces an emotional and somatic trajectory (or dynamic) that leads to a collectively shared somatic mode of

\footnotetext{
${ }^{5^{0}}$ Gallagher, How the body shapes the mind, 37.

${ }^{51}$ Ibid., 26.

${ }^{52}$ Csordas, Thomas J. "Somatic Modes of Attention." Cultural Anthropology 8 (1993), 138.
} 
attention. Additionally Collins highlights: "Collective attention enhances the expression of shared emotion; and in turn the shared emotion acts further to intensify collective movements and the sense of intersubjectivity." 53 This way, somatic attention arises from both somatic states of oneself and somatic states and body movements of others. Corporal intentionality, emotional response, as well as somatic states such as heart beat and blood pressure support this kind of attention to collective body movements, and movement as such becomes a source of somatic stimulation and synchronization.

Attending a collective bodily sensation, as in high arousal rituals, means to attend with the body in a social interaction, including the embodied presence of others and the synchronizing effects of their movements on one's own body. A body-schema then evolves by engaging in interactions with receptiveness to one's own body and by paying attention to the movements of other bodies. Yet, this attention is not primarily a conscious one, but somatic in terms of sensory perception and the felt presence of other bodies. Although one can certainly try to ignore or intentionally block out the presence of other persons, it is hard not to pay attention as our bodies seem to unconsciously pay attention to other bodies. Mirror-neurons, for instance, make our bodies unconsciously simulate bodily and emotional expressions of others. This is why people sometimes tend to end up in similar bodily postures or why they mirror each others' hand movements during a chat. "Other human beings and their bodily movements constitute a distinctive class of stimuli, because the movements of other human beings can be mapped onto our own bodies." ${ }^{44}$

Somatic modes of attention and collective body movements support an interactive synchronization between ritual participants and generate intersubjective embodied meanings. Whereas the theological, cultural or social meaning of a ritual can be acquired through cognitive abilities, the emergent intersubjective meaning is acquired through the embodiment of the interactive ritual performance. Bodily participation constitutes an enacted understanding of the ritual performance. "In effect, this kind of perception-based understanding is a form of body-reading rather than mind-reading. In seeing the actions and expressive movements of the other person one already sees their meaning; no inference to a hidden

53 Collins, Interaction Ritual Chains, 35 .

${ }^{4}$ Semin, Gün R. and John T. Cacioppo. “Grounding Social Cognition.” In Embodied Grounding, ed. Gün R. Semin and Eliot R. Smith, 119-47. Cambridge: Cambridge University Press, 2008, 120. 
set of mental states (beliefs, desires, etc.) is necessary." 55 The synchronizing effects in rituals, therefore, cannot be explained only in terms of consciously shared religious meanings but as collective somatic states which become embodied by the individual and create an embodied sense or meaning of the ritual interaction. But even more important, the collective bodily interactions result in an ongoing connectedness between the participants in terms of a collective body-schema that drives the ritual interaction, as will be explained in the following section.

\section{Synchronized Ritual Behavior and the Dynamics of Collective Rituals}

After reflecting upon the role of body-schemas in social interaction, we now can ask about the effects synchronized behavior has on the interactive coordination in ritual groups. It is evident that a collective effervescence occurs because of particular somatic states of arousal and embodied experiences rather than from conscious reflection and verbal communication. What is not so evident, however, is how the emergent dynamic of bodily synchronization changes individual behavior and begins to control the movements of the ritual participants. As already mentioned in the beginning of this chapter, Maurice Bloch correctly noted that in ritual synchronization "one is not sure whether it is oneself or another inside oneself who is acting and using one's voice and one's body. ${ }^{56} \mathrm{I}$ therefore argue that it is the emerging dynamics of the synchronizing bodies that controls the body.

The psychologists Semin and Cacioppo define synchronization "as jointly and simultaneously recruited sensory motor processes that are evident in a neurophysiological mirroring of the producer by the perceiver." ${ }^{57}$ If we consider, for instance, the synchronization of bodies through a rhythmic pulse, perception and action seem to fall together temporarily: "[W]hereas in most behaviors a response follows a stimulus, here the response is made to coincide with the stimulus. ${ }^{m 8}$ Rhythmic movements therefore anticipate the trajectory of the rhythm pulse and thereby enter a somatic loop that unconsciously drives the movements.

55 Gallagher, "The Practice of Mind", 9o.

${ }^{56}$ Bloch, "Are religious beliefs counter-intuitive?", 142.

57 Semin and Cacioppo, "Grounding Social Cognition", 123.

${ }^{8}$ Merker, "Synchronous Chorusing and Human Origins", 316. 
Thus, individual movements are no longer controlled by the individual's intentions when part of a collective ritual. In fact, bodily feedback systems constantly regulate such expressive behavior and coordinate the intentions' manifestation in real-world interactions. Intentional actions then become coordinated by one's synchronized interactions with other bodies. "In other words, by engaging in a structured activity, reliable correlations emerge between the motor activities involved and the perceptual input deriving from interactions with a specific environment." ${ }^{59}$

Take this common situation for example: Two walking persons encounter each other on a sidewalk. In their attempt to change direction to the left or right and to make way for the other person, both continuously step in the way of each other and almost collide. While one is moving a little bit to the right, the other one is synchronously moving to the left. In the next moment they change direction and again end up in the way of each other. During their encounter both share the same goal but seem to be unable to coordinate it successfully because their body movements seem to be intertwined momentarily. The individual movements follow a joint body-schema which emerges in the dynamics of collective interaction: "What arises in the process of coordination... can have the consequence of steering the encounter or facilitating (or not) its continuation." ${ }^{\prime 60}$

What this example demonstrates is that neither conscious thinking nor declared intentions in any interaction necessarily control the process of the interaction. As soon as bodies start to interact, the joint movements and synchronizing effects seem to at least partly coordinate the interaction. As a result, a collective or mutual body-schema emerges that enhances the synchronizing effects. In collective rituals we can find various interactions, with many different meanings, but it is the emerging effervescence of such synchronizing behavior that somehow steers the ritual encounter and this way embodies the ritual performance. Or, as Collins pointed out:

Interaction rituals in general are processes that take place when human bodies come close enough to each other so that their nervous systems become mutually attuned in rhythms and anticipations of each other, and the physiological substratum that produces emotions in one individual's body becomes stimulated in feedback loops that run through the other

${ }_{59}$ Gibbs, Embodiment and Cognitive Science, 76.

${ }^{60}$ DeJaegher, Hanne and Ezequiel Di Paolo. "Participatory Sense-Making: An Enactive Approach to Social Cognition." Phenomenology and the Cognitive Sciences 6, no. 4 (2007), 492. 
person's body. Within that moment at least, the social interaction is driving the physiology. ${ }^{61}$

To sum up, I have put forward the idea of bodily interaction and embodied synchronization in order to articulate a body-schema that drives the dynamics of collective rituals. This body-schema is partly based on neurophysiological dispositions such as mirror-neurons. It is helpful in describing the human ability to synchronize movements, which create new somatic patterns for interactions. Further, the embodied schema gives orientation to the world around us and partly constraints the way we perceive the world. It also is a disposition for embodied synchronization loops which drive the bodily dynamics of interactions.

\section{Conclusion}

This chapter began with a statement from Raymond Gibbs indicating the importance of considering bodies in action for theorizing on cognition and human behavior. Emphasizing such a dynamical understanding of social and embodied cognition contributes to develop integrative and nonreductionistic theories in the study of religion and the body. According to this perspective, cognition is grounded in processes of embodiment and therefore offers an alternative approach for theorizing body-mind relations, particularly for religious rituals.

Highlighting the fact that cognitive processing should not be seen apart from the body's engagement in social interactions further points toward the emergent effects of collective bodily synchronizations in rituals. The dynamics of ritual synchronization determine particular body-schemas through which we perceive and interact with the world, and which shape the embodied experience of ritual participants. Moreover, through bodyschemas ritual participants embody the collective meaning of the ritual performance.

Participating in a ritual performance, for instance, does not mean only to copy or imitate certain behavior but to engage in ritual (inter)action and to embody its dynamics. This way social interactions and bodily states influence psychological conditions, cognitive patterns, and even neural networks. The process of embodiment leaves its traces in our brains and

\footnotetext{
${ }^{61}$ Collins, Interaction Ritual Chains, xix.
} 
bodies. So far, this inquiry for an integrative model of embodiment can only represent a brief outline that needs further development.

Finally, religion in general and religious rituals in particular cannot be explained sufficiently on the basis of cognitive mechanisms and psychological preconditions alone. Religious representations and ritual behavior also emerge through collective interaction and synchronization. Thus, my intention was to bring together fruitful approaches from cognitive and social science to stimulate further investigations into the interrelations between the mind and our bodies in action for future research on embodied ritual behavior. 

SECTION TWO

CULTURE AND THE DE- AND RE-CONSTRUCTION OF THE BODY 



\title{
RELIGION, NEUROSCIENCE AND EMOTION: SOME IMPLICATIONS OF CONSUMERISM AND ENTERTAINMENT CULTURE
}

\author{
Rebecca Sachs Norris
}

A neuroscientific view of the structure of emotion suggests that the contemporary western ethic of emotion reflected in reality shows and other media weakens the deeper development of feeling and devalues the role of inner discipline in religious practice. Religious conservatives have made similar claims, but the aim of this chapter is not to make moral judgments or accusations, rather simply to explore the implications of our current culture of entertainment, what I have elsewhere referred to as the 'cult of fun, ${ }^{1}$ for religious development.

The basis of this assertion concerning the effects of contemporary emotional behavior is the role of the emotions in transmitting religious knowledge, a role that is also a significant factor in the process of enculturation. Emotion is central in shaping religious experience and understanding. How, then, does the current western cultural perspective on emotion relate to 21st century American religiosity? The contemporary ethic of emotion finds authenticity in emotional expression. Sentiment and passion rule in a cultural environment of fun and entertainment, dominant even in newscasts, education (edutainment), and religion (religiotainment). ${ }^{2}$ What are some of the implications of the contemporary culture of fun in relation to the role of emotion in religious enculturation and in the transmission of embodied religious knowledge? Neuroscience is a useful tool for this investigation, and is a vehicle as well for reflection on religion and the naturalized body.

One of the symptoms and results of the contemporary conceptualization of the naturalized body is the conflation of 'body' with its biochemical structure, resulting in a materialist understanding of the human organism. Materialism, in this context, is often reductionist, leaving us no purpose or reason for structure or behavior except the needs and desires

${ }^{1}$ Bado-Fralick, Nikki, and Rebecca Sachs Norris. Toying with God: The World of Religious Games and Doll. Waco, TX: Baylor University Press, 2010s, 119.

${ }^{2}$ Ibid., 175, 178-9. 
of the physical organism (such as adaptive evolutionary requirements). It is possible, however, to bring neuroscience and religion together with a non-reductionist approach that preserves the transformative and experiential capacities of body and emotions.

One of the areas open to such exploration is the structure of the emotions, which can be evoked through memory, unlike physical sensations such as pain or pleasure, which require a physical stimulus. ${ }^{3}$ This experiential characteristic is paralleled by neurochemical activity. It is useful for religious studies scholars to understand the neuroscientific foundations of the structure of emotion, a structure that religious traditions make use of to inform feeling and transmit religious knowledge. Further, this study gives us insight into the process of enculturation.

This chapter begins by examining the structure of emotion in relation to religious experience and enculturation. The next section examines contemporary conceptual models of emotion, for example, the media insistence on displaying passion. The last section considers some of the implications of these contemporary models in light of the role of emotion in religious development.

\section{Neuroscience and Emotion ${ }^{4}$}

The structure of emotion and its developmental processes are the same within secular or religious contexts. ${ }^{5}$ In religious contexts, emotion can be understood as a form of religious knowledge as well a means of transmission of that knowledge. One of the motivating questions behind this research is how a state that is considered unable to be described or conveyed with words, such as higher or deeper states of prayer or meditation, can be conveyed or learned.

3 Phantom pain is an exception, of course, but it is still not evoked through memory.

${ }^{4}$ Some of this section is a revised version of material originally published in Zygon. Norris, Rebecca Sachs. "Examining the Structure and Role of Emotion: Contributions of Neurobiology to the Study of Embodied Religious Experience, Zygon 40, no. 1 (2005): $181-99$.

${ }^{5}$ In fact, this material could be seen to provide support for Ann Taves' assertion that religious experiences are religious because people consider them so, not because there is something innately different about them from other experiences that are considered special (Taves, Anne. Religious Experience Reconsidered: A Building Block Approach to the Study of Religion and Other Special Things. Princeton \& Oxford: Princeton University Press, 2009). 
The transmission of religious states involves the process of embodiment of cultural differences. We know that experience and identity (understood as embodied experience of self in the world) are culture-specific, but how does enculturation take place? Most work on neuroscience and religion focuses on brain states during religious experience such as meditation. In contrast, this study of neuroscience and emotion investigates process.

In brief, certain properties of the body and of emotions enable the transmission of religious knowledge and the development of religious states, through particular qualities of perception and memory. The body and emotions have their own modes of cognition, which are immediate (non-verbal or pre-verbal) and polysemic. Our sense organs and emotions function without descriptions or mediation from the intellect, and are attuned to take in types of impressions to which they are specifically adapted. Ritual, gesture, posture, images, and other somatic practices and perceptions enculturate and transmit by means of these capacities. These particular properties and their functioning is an extensive topic; the focus here is on the characteristic that recalled emotion is 'refelt' in the present. ${ }^{6}$

'Refeeling' enables the cultivation or development of emotion, which is central to transmission of embodied religious knowledge. Emotions and the stimuli that evoke them are culturally specific, but the automatic nature of this process is universal. Religious traditions have made use of this to educate the feeling toward certain qualities and to develop religious experience, through the use of sacred images, ritual posture and gesture, and repetition of ritual acts. Neuroscience contributes to our understanding of the emotional processes that take place when emotions are evoked, refelt and developed, because the neurobiological processing of emotion parallels experience. Since the experiential and neuroscientific mirror each other, each can contribute to the fuller picture; it is therefore possible to bring neuroscience to the religious studies table in a way that is neither functionally nor descriptively reductionist.

It would be helpful here to be able to include some definition of emotion, but that is a difficult task indeed. To say that emotions are affective responses to inner or outer stimuli does not get us very far because then we have the difficulty of defining affect. A list of emotions (happiness, sadness, fear, joy) is somewhat helpful, but it does not tell us what

${ }^{6}$ Martin, F. David. Art and the Religious Experience: The "Language" of the Sacred. Lewisburg, PA: Bucknell University Press, 1972, 190. 
emotions are. Furthermore, each discipline (and culture) has its own ways of understanding emotions, their function(s), and their functioning. To compound this, since emotions are socially educated and culturally specific, there is little common ground to stand on, and little can be generalized about how people experience emotion. The difference between emotion and feeling is also troublesome, in part because 'feeling'has a variety of meanings. One can 'feel' (experience) sadness, 'feel' (sense) heat or other sensations, or 'feel' (think) that something is a good idea. The difference between emotion and sensation is also not clear, since many or even most emotions are accompanied by sensations.

Catherine Lutz and Geoffrey White, in "The Anthropology of Emotions," examined the many opposing approaches to emotion expressed up to that time (1986), including "materialism and idealism, positivism and interpretivism, universalism and relativism, individual and culture, and romanticism and rationalism."7 Charles Lindholm ${ }^{8}$ analyzes anthropological research on emotion, considering the multiplicity of models in historical perspective. Ilkka Pyysiäinen notes the range of theories of emotion, with neurophysiological at one end of the spectrum and social constructivism at the other. ${ }^{9}$ Neuroscientist Antonio Damasio conceives of emotion as bodily states and feelings as the awareness of emotionthat is, a higher-level state in which the organism knows that it feels the emotion. ${ }^{10}$ Similarly, Joseph LeDoux refers to feelings as "conscious emotions." ${ }^{\prime \prime}$ The terms emotion and feeling may be differentiated or used interchangeably.

The essential point in this exploration is a functional one-the process and structure of emotion. Consider the characteristic mentioned above that recalled emotions are refelt in the present. This differentiates emotional from sensory memory. The memory of a sensation, pain for instance, is not experienced as it is remembered, whereas an emotion is. If you have ever had surgery or a broken bone, when you think back to that time you

\footnotetext{
7 Lutz, Catherine, and Geoffrey White. "The Anthropology of Emotions." Annual Review of Anthropology 15 (1986): 405-36, 406.

${ }^{8}$ Lindholm, Charles. "Creating an Anthropology of Emotion." In A Companion to Psychological Anthropology: Modernity and Psychocultural Change, edited by Casey Conerly. Oxford: Blackwell Publishers, 2004.

9 Pyysiäinen, Ilkka. "Cognition, Emotion, and Religious Experience." In Religion in Mind, edited by Jensine Andresen, 70-93. Cambridge: Cambridge University Press, 2001, 85 .

${ }^{10}$ Damasio, Antonio. The Feeling of What Happens: Body and Emotion in the Making of Consciousness. San Diego, New York, London: Harcourt, Inc., 1999, 81.

${ }^{"}$ LeDoux, Joseph. The Synaptic Self: How Our Brains Become Who We Are. New York: Viking, 2002, 206.
} 
may wince because you remember that you were in pain, but you do not experience the pain again. Similarly, pleasurable sensations are remembered but not re-experienced. In contrast, if you remember a time when you embarrassed yourself in public you cringe because you experience it again. When you listen to songs that held great meaning for you in high school, they evoke the same feelings even thirty years later. In the same way, a person will re-experience a specific emotion each time they are in the same circumstances that evoked that emotion originally-assuming it holds sufficient affective power and has been culturally amplified. This structure of emotion - that it can be re-evoked and refelt-enables the developing of and building on previous feelings; they can be refined and cultivated intentionally through discipline and training, and are capable of gradations of experience.

The development and socialized learning of emotion is one of the ways in which culture, particularly religious culture, is transmitted. Though the processes are universal, they take place within particular contexts, thus the results are culture-specific. Practices and sensory images ${ }^{12}$ handed on through ritual and tradition communicate not only the outer manifestations of a culture but also beliefs and experiences; an individual's experience of body and self cannot be separated from enculturated concepts of human identity and relation to a deity or the transcendent.

The fact that emotion can be refelt in the present when it is recalled enables religious feelings to be developed. For example, in ritual the repetition of gesture along with the affective power of sensory imagery reevokes emotion linked with that ritual act, and new emotional memories are laid down in association with the old ones, all of which can be recalled the next time.

Neuroscience elucidates the process of enculturation by enabling us to understand this process from a different perspective. In The Feeling of What Happens, Damasio indicates that re-experiencing an emotion means that the biochemical (humoral) and electrochemical (neural) processes ${ }^{13}$ that are the sources of what we experience as 'emotions' are recurring. If a given set of conditions evokes a particular response in an organism (for example prostration in salat evoking a feeling of submission), another

\footnotetext{
12 'Images' in this case refers to any sensory imagery - visual, auditory, olfactory, proprioceptive, etc. Thus not only statues and art, but music dance, architecture, cooking and other sensory ritual elements convey religious knowledge.

${ }_{13}$ These processes take place in the subcortical nuclei of the brain stem, hypothalamus, basal forebrain, and amygdala.
} 
occurrence of that set of conditions will evoke the same biochemical and electrochemical response, that is to say, the same emotion. ${ }^{14}$ Repetition also enables an emotion to be more easily evoked and recalled, because of the process by which neurons get tuned to each other so as to 'fire more easily,' called long-term potentiation. ${ }^{15}$

The intentional training, or education, of feeling draws on the fact that cultivation and intensification of emotions is possible precisely because of this quality of being refelt. At the molecular level, in Molecules of Emotion neuroscientist Candace Pert notes that "neuropeptides can act as internal ligands to shape our memories as we are forming them, and put us back in the same frame of mind when we need to retrieve them. This is learning. ${ }^{{ }^{\prime \prime}}$ Damasio explains the triggering of emotion as follows:

The appearance of an emotion depends on a complicated chain of events... In neural terms, images related to the emotionally competent object must be represented in one or more of the brain's sensory processing systems, such as the visual or auditory regions... signals related to the presence of the stimulus are made available to a number of emotion-triggering sites elsewhere in the brain. You can conceive of those sites as locks that open only if the appropriate keys fit. The emotionally competent stimuli are the keys, of course. Note that they select a preexisting lock, rather than instruct the brain on how to create a new one. The emotion-triggering sites subsequently activate a number of emotion-execution sites elsewhere in the brain.... Eventually the process can reverberate and amplify itself, or shrivel and close down. ${ }^{17}$

This process, which moves towards amplification or contraction, underlies the development of emotion; here lies the possibility for change and deepening, rather than a static, unchanging refeeling of an emotion. The contents of the mind (related stimuli) can amplify an emotional response through a parallel chain of recall..$^{18}$ Thus the emotional response has the potential to develop-each time a response takes place it is not only an outward-directed response, but it also augments and reinforces the neurological connections in associated areas of the brain. Furthermore,

\footnotetext{
${ }^{14}$ Damasio, Antonio. Looking for Spinoza: Joy, Sorrow and the Feeling Brain. San Diego, New York, London: Harcourt, Inc., 2003, 79-80.

${ }^{15}$ Joseph LeDoux, The Synaptic Self: How Our Brains Become Who We Are., 303; Maturana, Humberto, and Francisco Varela. The Tree of Knowledge: The Biological Roots of Human Understanding. Boston: Shambala, 1987, 168; Hogue, David. Remembering the Future, Imagining the Past: Story, Ritual, and the Human Brain. Cleveland: Pilgrim, 2003, 64.

${ }_{16}$ Pert, Candace. Molecules of Emotion. New York: Scribner, 1997, 144-5.

${ }_{17}$ Damasio, Looking for Spinoza, 57-8.

${ }^{18}$ Ibid., 58 .
} 
according to neuroscientist Joseph LeDoux, "Emotion systems learn by association-when an emotionally arousing stimulus is present, other stimuli that are also present acquire emotion-arousing qualities." ${ }^{19}$

Emotional responses are evoked by culturally specific stimuli (emotionally competent stimuli), connected through the process just described. Hearing the Quran will induce a particular religious feeling in a Muslim but not the same in a Buddhist. Differences within traditions are also evident; hearing recitations from the Quran accompanied by music in dhikr will stimulate a calm, communal trance in middle-class Egyptian Sufis, ${ }^{20}$ but a self-mutilating amnesiac trance in the Hamadsha. ${ }^{21}$ The same kinds of differences can be found in any religious tradition. Anthropologist Talal Asad, for example, has discussed the training of religious emotions and their historical and cultural uniqueness in relation to Christianity:

The rites that were described by that program did not simply evoke or release universal emotions, they aimed to construct and reorganize distinctive emotions-desire (cupiditas/caritas), humility (humilitas), remorse (contritio) - on which the central Christian virtue of obedience to God depended. This point must be stressed, because the emotions mentioned here are not universal human feelings.... They are historically specific emotions that are structured internally and related to each other in historically determined ways. ${ }^{22}$

Material is established through religious education, reading of religious texts, performance of ritual, and so on. Note that emotionally competent objects can be either actual or remembered, ${ }^{23}$ so through association with a current emotion, more stimuli can be called into action, amplifying the emotion and creating more related stimuli for the next time. The experienced response is amplified because these contents exist; repeated experience increases related stimuli and amplification increases. This is enculturation. ${ }^{24}$

${ }^{19}$ JLeDoux, The Synaptic Self: 303, emphasis mine.

${ }^{20}$ Waugh, Earle H. The Munshidin of Egypt. Columbia: University of South Carolina Press, 1989 .

${ }^{21}$ Crapanzano, Vincent. The Hamadsha. Berkeley: University of California Press, 1973.

${ }^{22}$ Asad, Talal. Genealogies of Religion. Baltimore: The Johns Hopkins University Press, 1993, 134 .

${ }^{23}$ Damasio, Looking for Spinoza, 57.

${ }^{24}$ Buddhist scholars (and others) may argue that I am generalizing a culturally specific view of emotion that is not universal. Buddhist psychology for example, understands emotions as mental factors. The difference in perspective can also be seen in the fact that there is no Tibetan word that translates directly as "emotion" (Dreyfus, Georges. "Session 3: Emotion." In Mind and Life XI: Investigating the Mind: Exchanges between Buddhism and the 
In summary, recalled emotions are refelt in the present; in terms of neurobiology that means that specific bio- and electro-chemical processes are recurring. Additionally, emotions are evoked by stimuli (which Damasio, above, refers to as emotionally competent stimuli) that are learned and culturally specific. Connections between stimuli are not limited or fixed. New connections can be made, enabling emotional and experiential development.

The modification of memory and experience, through repetition and recall, is part of the human structure that creates the possibility for lifelong development. This is a result of human malleability that allows us experiences of different intensities and meanings, as well as giving humans the ability to adapt and transform. Repetition, imitation, ${ }^{25}$ and the use of images in learning prayer or other rituals enable ever-changing and deepening experience through plasticity and creation of new related stimuli. This is not simply a passive potential; practitioners are not merely worked on through random forces but are also trained through deliberate use of these qualities, whether externally or internally motivated. Sacred images, for example, which depict specific postures or gestures associated with corresponding feelings, can and have been used not only to evoke feelings, but also to educate the feeling toward certain experiences. According to theologian Margaret Miles, images embody spiritual qualities, ${ }^{26}$ and were used intentionally for this education. ${ }^{27}$

Biobehavioral Sciences on How the Mind Works. Kresge Auditorium, Massachusetts Institute of Technology, Cambridge, MA, 2003). Mental factors are understood to characterize and qualify the object of awareness; some examples of mental factors are confidence, anger, drowsiness, doubt, wisdom, and spite. Clearly some of these would come under the heading of emotion, though not all of them would. Regardless of how they are classified, it is the mechanical nature of emotion that is of concern. One aim of Buddhist practice is achieving freedom from just this automatic reaction of emotion (or other mental factors) - not an effort to not experience them, but an effort to not be controlled by automatic reactions, the process I have been describing. See also J Leavitt, John. "Meaning and Feeling in the Anthropology of Emotions." American Ethnologist 23, no. 3 (1996), 516.

${ }^{25}$ Mirror neurons, "a special class of brain cells that fire not only when an individual performs an action, but also when the individual observes someone else make the same movement," (Iacoboni, Marco. "Mirror Neurons." Society for Neuroscience, http://www.sfn .org/index.aspx?pagename=brainBriefings_MirrorNeurons), may be of interest in examining imitation and transmission of religious states through seeing others. We already know through experience, however, that our bodies experience the bodily states of others, for example seeing images of torture, or of an amputee elicits direct somatic responses.

${ }_{26}^{26}$ Miles, Margaret. Image as Insight. Boston: Beacon Press, 1985, 143.

${ }^{27}$ Images are an essential part of ritual practice and transmission of religious knowledge. Images are processed by different parts of the brain. To some extent the hippocampus is responsible, but also just as the brain repeats internally what is heard, "there is an inbuilt tendency for the mind/brain to have a representation in the motor area of what 


\section{Consuming Emotion}

The neurobiological structure of emotion is presumably the same in 21st century America as it has been for millennia, but current attitudes towards the role of emotions are a long way from the intentional shaping that Miles and others reference. While scholars, therapists, and educators may be interested in concepts such as emotional intelligence, the model of emotion that is evident in popular culture and the media is based on an understanding of specific ways of feeling and displaying emotion as indicators of authenticity and the gateway to success. Colin Campbell's work The Romantic Ethic and the Spirit of Modern Consumerism shows us that the roots of this attitude are the same as the roots of modern consumerism. We have seen that emotion is one of the sources of religious enculturation. In light of this what are the implications of the current consumerist orientation to emotion?

The term 'consumer culture,' or 'consumerism,' ordinarily refers to 'lifestyles and cultures structured around consumption", ${ }^{28}$ meaning consumption of goods. But media and marketing are also pushing emotions and other personal experiences such as fun, and like the products of other 'pushers' what they are pushing makes us feel better temporarily, and can be addicting. We are not just consuming material objects; we are also consuming our experiences, which have themselves become goods.

Consumerism and emotions are linked in a number of ways. David Lyon asks what are the "dreams and desires celebrated within consumer cultural imagery? What do people consume? What do they get out of it?", ${ }^{29}$ and argues that in postmodern consumerist society we shop for an identity. Consumerism is a form of identity construction, in which we choose

\footnotetext{
ever movement, usually by another human, appears in the visual system" (d'Aquili, Eugene, and Andrew Newberg. The Mystical Mind. Minneapolis: Fortress, 1999, 88). Seeing another practitioner take a particular posture or gesture, a sensory representation is made in the viewer's brain. As stated earlier, when that posture or gesture is then taken, many layers of experience are evoked-the emotional memory, religious associations and beliefs, kinesthesia, and more. The kinesthetic experience is specific to a given posture, and that experience is direct, unmediated by the intellect. Transmission of particular concepts and feelings is a process of internal recognition rather than external explanation, a "particular neural grouping cued to a certain frequency response." (Pearce, Joseph Chilton. Biology of Transcendence: A Blueprint of the Human Spirit. Rochester, VT: Park Street Press, 2002, 35). This does not occur as a conscious cognitive event, but as a direct embodied experience.

${ }^{28}$ Lyon, David. Jesus in Disneyland: Religion in Postmodern Times. Malden, MA: Polity Press, 2000, 77 .

29 Ibid., 78.
} 
from here and there, recreating our selves continuously. Thus while 'consumer culture' is often used as a critical term, identity construction can be understood as one of its positive functions; social bonding is another. The contemporary Western focus on emotion and fun is another manifestation of consumer culture, whereby we not only create, but also consume our self-representations. Our inner lives, as well as outer personalities, are terrain to be constructed, through consumption and choice. Emotions are glorified, but only the easy ones. We are supposed to be happy and having fun; consuming is one way of creating these emotions within ourselves, and creating these emotions within ourselves is another way of consuming. Positive emotions are commodities.

The concept of the naturalized body is one formative element in this contemporary cultural articulation, in particular the understanding and highlighting of the body as individual. Without this we would not have the emphasis on personal experience as a goal that we see in advertising, social media, and in contemporary Western culture in general. Clearly, this is also an aspect of modern religiosity as well, with its emphasis on personal spirituality rather than participation in organized religion.

Another way in which the naturalized body informs a consumer perspective on emotion is the materialist emphasis on the body as a physical organism. If all we have is one lifetime, and what we are is a body, why discipline emotional desires, why not satisfy them? The transcendent aims and states referenced by religious traditions cannot be scientifically proven, whereas we know our present experience directly, and it is real to us now.

What is being offered to us through media, advertising, and cultural constructions of emotion is not just personal experience, but specific types of personal experience - the emphasis is on feeling good and having fun. The evidence is all around us, from feel-good religious beliefs like the warm and fuzzy Jesus exemplified in the Holy Huggable talking Jesus doll, to the 'funtivities' of today's corporate world, to windshield replacement..$^{30}$

Like texting and tweeting as abbreviated forms of communication, we are used to and urged towards short-lived, self-satisfying emotions. But these emotions and self-expressions must also appear to be authentic and passionate in order to fulfill cultural expectations. Modeling reality shows on television are some of the best illustrations of this inclination. In a

\footnotetext{
$3^{30}$ Bado-Fralick and Norris, Toying with God, 179, 114-115, 119.
} 
typical example, the host says to one contestant about a photo where she evoked tears "It's beautiful because it's a real emotion." ${ }^{11}$ Over and over on "America's Next Top Model" (the original and still the prime example of these shows) the finalists are exhorted to show their 'passion'—and this exhortation is not seen just on modeling shows. On cooking shows ("Top Chef," "Master Chef," "Chopped," "Next Food Network Star") and design shows ("Next Design Star") contestants are eliminated if they cannot show sufficient emotional intensity, or allow the judges to see their 'authentic selves.' They have to reveal their real selves, and they must show that they care.

Authenticity, as a cultural value, is historically and culturally constructed, as are specific models of authentic cultural identity such as French cheese, Indian curry or Cuban rumba. ${ }^{32}$ In a culture that requires authenticity (whether we genuinely feel like it or not) the question arises as to whether 'authenticity on demand' is, or can be, authentic. Indeed, that the question even comes up is a mirror of the place that this characteristic holds in our society, since we want our authenticity to be authentic. Nonetheless, being genuine, revealing one's true self, sharing feelings honestly, are held as ideals. ${ }^{33}$

The emphasis on the appearance of authenticity through expression of feeling has its roots in romanticism, in the movement away from the developing histrionics of the 18th century ethic of sensibility:

The evolution of sensibility into a full-blown romanticism can be seen as following, at least in part, from the necessity of defending a philosophy of feeling against its detractors, something which placed an excessive strain upon the attempted association of the values of sincerity and propriety. For

$3^{31}$ "She's Got the Look." 2010.

$3^{2}$ Lindholm, Charles. Culture and Authenticity. Malden, Oxford: Wiley-Blackwell, 2008.

33 The push for authenticity, as well as honesty, which is a counterpart, is contradictory as well, since many or most of us would lose our jobs if we were to tell our bosses our authentic feelings, and world politics throughout history have hardly been based on openness and 'being real.' An example of the friction between the cultural ideal of authenticity and the 'real' world, is Wikileak's outing of "quarter-million confidential American diplomatic cables" in November, 2010, which was potentially not only disruptive, but also dangerous. "The disclosure of the cables is sending shudders through the diplomatic establishment, and could strain relations with some countries, influencing international affairs in ways that are impossible to predict... The White House said the release of what it called 'stolen cables' to several publications was a 'reckless and dangerous action' and warned that some cables, if released in full, could disrupt American operations abroad and put the work and even lives of confidential sources of American diplomats at risk" (Shane, Scott, and Andrew Lehren. "Leaked Cables Offer Raw Look at U.S. Diplomacy." New York Times online, November 28, 2010). 
the accusation that such an ethic encouraged dissembling, hypocrisy, indifference to suffering, and even cruelty, could only really be countered by arguing that these were not the products of 'true' sensibility, but rather the outcome of behavior governed by conventional expectations. If, therefore, people did allow themselves to be honest, and were to let their actions flow directly from their natural feelings instead of feigning that which they did not feel, such undesirable attitudes would not be created. ${ }^{34}$

A further result, according to Campbell, is that the Gothic and sentimental novels of the time were one of the factors leading to dissatisfaction with traditional patterns of life and thus a break with traditionalism. ${ }^{35}$

The media requirement for change and superficiality, ${ }^{36}$ a descendent of this dissatisfaction, pervades almost every aspect of contemporary American culture today, transforming seemingly every cultural manifestation into a form of entertainment, even pedagogy. In "Good Teaching: The Top 10 Requirements," an article from the online higher education resource Faculty Focus, points 5 and 10 both mention entertainment:

Five. Good teaching is also about style. Should good teaching be entertaining? You bet! Does this mean that it lacks in substance? Not a chance! Effective teaching is not about being locked with both hands glued to a podium or having your eyes fixated on a slide projector while you drone on. Good teachers work the room and every student in it...

Ten. At the end of the day, good teaching is about having fun, experiencing pleasure and intrinsic rewards... ${ }^{37}$

And significantly, the first, and presumably thus the most important of the ten points, states at the very beginning: "Good teaching is as much about passion as it is about reason" [emphasis mine]. Entertainers, newscasters, reality show contestants, and professors are expected to feel and display strong emotion-even President Obama was found lacking when he did not display sufficient affect:

${ }_{34}$ Campbell, Colin. The Romantic Ethic and the Spirit of Modem Consumerism. Oxford, New York: Basil Blackwell, 1987, 176-77.

35 Ibid., 176.

${ }^{36}$ Superficiality and authenticity may seem to be contradictory qualities, but the social requirement for authenticity means that it is the display that is required. In other words, it is the appearance of being genuine that matters, and any time appearance is the goal, it is superficial, meaning on the surface.

37 Leblanc, Richard. “Good Teaching: The Top 10 Requirements.” http://www.faculty focus.com/articles/philosophy-of-teaching/good-teaching-the-top-10-requirements/. 
... they demand that the president "take control." They demand that he hold press conferences, show leadership, announce that the buck stops here and do something. They want him to emote and perform the proper theatrical gestures so they can see their emotions enacted on the public stage..$^{8}$

This issue was such a prominent topic of public conversation that in September 2010 it even earned a series of Doonesbury comic strips on the efforts of President Obama's advisors to get him to show more emotion.

Of course, it is not as though there were a distinct separation between entertainment and politics in any case; our culture of amusement has encroached upon all spheres of public life.

The thirst for fun is so all-pervasive in American culture that at times it feels like a form of social lunacy. Life imitating art imitating life. How else can one explain Republican vice presidential candidate Sarah Palin's appearance on Saturday Night Live during the 2008 presidential campaign? Contemporary American culture, its media permeated by advertising and marketing, is a living form of Alice through the Looking Glass, where many can no longer tell seriousness from levity, news from advertising, information from entertainment, or authenticity from gloss. ${ }^{39}$

Neil Postman wrote about this trend in Amusing Ourselves to Death: Public Discourse in the Age of Show Business, ${ }^{40}$ originally published in 1985 , and it has become significantly more pronounced since then. In an era when dissemination of information on television is controlled by only six corporations ${ }^{41}$ there is a constant effort to increase ratings and profits; passion and emotion are put to work to this end.

The media must capture the full panoply of presidential emo and put it on their teevees, for the ratings! And the best part of it is that no amount of emotion, of raging, of garment rending, will ever be enough. As [Washington Post blogger] Greg Sargent dryly notes: "The real point is that this standard isn't designed to be met." ${ }^{42}$

\footnotetext{
${ }^{38}$ Brooks, David. “The Oil Plume.” New York Times online, 5/31/10 2010.

39 Bado-Fralick and Norris, Toying with God, 116.

${ }^{40}$ Postman, Neil. Amusing Ourselves to Death: Public Discourse in the Age of Show Business. New York, etc.: Penguin Books, 2006.

${ }^{41}$ Bado-Fralick and Norris, Toying with God, 116.

${ }^{42}$ Linkins, Jason. "White House Press Corps' Latest Obsession: Obama's Emotional State." The Huffington Post, http://www.huffingtonpost.com/2010/o6/o2/white-housepress-corps-1_n_597538.html.
} 
This is reminiscent of what Campbell says about consumerism: “...the very essence of modern consumption itself-its character as an activity which involves an apparently endless pursuit of wants; the most characteristic feature of modem consumption being this insatiability." ${ }^{\prime 3}$

Perhaps some of this insatiability is due to the unsatisfying nature of what we are trying to sate ourselves with: mechanical emotions, sentiment, tweeted personal updates, truncated news items. One of the terms commonly used to refer to practices of abbreviating information, 'sound bites,' leads us directly back to the consumer-oriented basis of entertainment culture-we consume these 'bites' like amuses bouches at an A-list soirée. Temporarily satisfying, but hardly filling.

What would earlier have been seen as a contradiction between news and entertainment has dissolved in the ongoing reshaping of social forms from traditional to postmodern. The contradiction between religion and entertainment likewise has transformed. Religious institutions and practices are certainly not exempt from contemporary cultural influences; one result of this influence is the feel-good religions that are so prevalent. A good example is the popular TV personality Deepak Chopra, whose Chopra Center website claims "the path to wellness begins here." The scrolling promotions for upcoming workshops feature titles such as "Free to Love-emotional healing workshop," "Journey into healingmind-body wellness,: "Chopra Center Radio-an hour of enlightenment," "SynchroDestiny-harness the power of coincidence," with images of serene Caucasian men and women in peaceful nature settings with links to specific programs ${ }^{44}$ An hour of enlightenment? This is a far cry from traditional religious disciplines such as periods of intensive Zen meditation (sesshins), Christian monastic practice, or fasting for Ramadan.

The fusion of religion, consumerism, and fun also produces contemporary forms of religiotainment ${ }^{45}$ as in religious amusement parks, religious games and dolls, or religious educational products and media such as Godly Play, ${ }^{46}$ and The Donut Man:

${ }^{43}$ Campbell, The Romantic Ethic and the Spirit of Modem Consumerism, 37.

${ }^{44}$ "The Chopra Center." http://www.chopra.com/. (The only obvious exception to the white faces is a side view, apparently of Chopra himself, under the program label "Spiritual Awakening," evoking the orientalism of the past and the exoticizing of Eastern spirituality.)

${ }^{45}$ Bado-Fralick and Norris, Toying with God, 178.

${ }_{46}$ "Godly Play." www.godlyplayfoundation.org. 
Rob Evans-The Donut Man-is known for his fun, yet instructive Bible story-songs presented via DVD's, CD's and live concerts. He is a 'Donut Repair Man' ... Why? He uses a donut to illustrate how something can be good, and yet still have something missing. On the most basic level, kids get to fill the hole in a donut with a pastry ball and then eat it! This 'edible object-lesson' points to a profound truth: that we are all made in God's image, and have a "God-shaped empty-place that only God can fill! That's why every 'Donut Man' CD, DVD and concert shows how God's love 'repairs' our lives. ${ }^{47}$

Other manifestations are mega-churches that aim to have something for everyone, including classes on eBay savvy and a "Sonbucks" (as in the Son of God) in place of Starbucks, ${ }^{48}$ religious music videos, and a seemingly infinite number of new religious apps. And the diversity and quantity of religiously-themed articles in the marketplace now, from disposable party napkins to jewelry, is an indication of the extent of religion's full participation in consumer life, the commodification of religion.

In spite of these developments, tension between religion and fun is still evident in Western culture, although considering the number and significance of festivals such as Holi, Purim, and Mardi Gras, it appears that the conflict may be in the eyes of scholars rather than practitioners.

Within the Abrahamic traditions, however, explorations of the playful aspects of ritual are likely to be somewhat rare in the scholarship due to the ways in which religion and play are characterized within Western culture. It's not that ludic rites don't exist in these traditions, but we often don't think to look for them, or we leave their collection and discussion marginalized as oddities for folklorists, rather than religious studies scholars, to study. ${ }^{49}$

The association of religion and fun is problematic as well for religious authorities and those who prefer 'traditional' forms of religious belief and practice. For instance, fun and play involve a letting go of control; at the extreme they can be subversive. In contrast, it is hardly necessary to note that institutional religion requires control in order to survive.

But the opposition between fun and religion goes deeper than that. According to sociologist Russell Heddendorf fun and play somehow detract from the seriousness of religion.

47 "Meet the Donut Man." http://www.donutman.com/?page=meetdonutman.

${ }_{48}^{8}$ Fitzgerald, Frances. "Come One, Come All." The New Yorker, Dec. 3, 2007, 46-56.

49 Bado-Fralick and Norris, Toying with God, 145. 
...the enriching experiences offered by seriousness are ignored or misunderstood and we remain impoverished by a worldview of fun ... fun denies the ordinary by escaping from it and then distorting it, simply because there is no fun in the ordinary or the familiar. Since any serious thought or action threatens fun, those thoughts and actions must be mocked; they can't be taken seriously. Opposing the serious, fun negates the value of the logical or the moral and seeks to replace the ordinary with the extraordinary. And in the process, fun replaces other traditional values with its own. It elevates all that is laughable and illogical and encourages the immoral and frightening..$^{0}$

Since religion addresses our deepest human concerns and identity, it seems reasonable to worry that fun will dilute or distort traditional moral and existential messages. This viewpoint is not universal, however. For example, Eastern traditions, such as Hinduism, do not share the dichotomous division between religion and fun (witness the idea of lila, the play of the gods). And rituals of reversal and communitas, such as Carnival, or the preliminary rituals of the Sioux Sundance incorporate play as well.

It is not that the Abrahamic religions do not include positive emotions. As in other religions, happiness, joy, bliss, and ecstasy are understood to be found in particular relations with God or the sacred. Religious emotion ranges from the shallower, ego-directed emotions at one end of the spectrum, which are non-developmental (that give only a sense of pious self-satisfaction, for example), to those in transcendental experience, be this loss of self in Allah, Christian union with God, or nirvana, at the other end of the spectrum. But with the exception of the shallower emotions, the positive emotions reference something outside the self. They may still be pleasurable (or blissful) experiences, but the aim, ideally and in theory at least, is not the personal experience itself. Conversely, not every emotion in a consumer culture is shallow and self-directed. The perception of over-consumption can lead to compassion and great philanthropic efforts, for example. But in general, the impetus is to feel good in order to feel good; the insatiability of emotional life mirrors the insatiability of consumerism. Consuming feeds the need to consume, whether it is of goods or of emotions.

The 'something outside the self referenced by religious emotion is a transcendent reality, the sacred. And it is interesting to consider that just as religion references a reality outside the ordinary, so too does play,

\footnotetext{
$5^{5}$ Heddendorf, Russell. From Faith to Fun: The Secularisation of Humour. Cambridge, UK: The Lutterworth Press, 2009, 185.
} 
according to both Johan Huizinga and Roger Callois, seminal authorities on play. ${ }^{51}$ In fact, this is one of the defining characteristics of play. Perhaps this is an even stronger reason for the tension between religion and fun: competing alternative realities. The implications of this involve questions of spiritual growth and the structure of emotion discussed earlier. If one can easily access an alternative reality through fun and play, provided through almost every cultural manifestation in a consumer culture, then why suffer physical hardships and spiritual disciplines to access another reality? This question is reinforced by the scientific worldview underlying consumer culture, which considers that the existence of a religious reality cannot be proven, and that the self at the heart of this issue is primarily considered a naturalized body. If the materialist perspective dictates that only the body exists, why then would we not satisfy the need for release from the ordinary through our naturalized bodies? Fun, consumption, and passion provide this release; they gratify the naturalized body. In contrast, religious paths provide release from the ordinary by requiring the disciplining of the naturalized body, but with no observable proof that there is reason (the existence of a sacred dimension) to do so.

\section{Implications}

The expression of the emotional self, the passion called for in contemporary Western culture, necessarily feels authentic due to enculturation. Emotions are learned through mirroring externally and then internally those that are permitted, encouraged, and displayed by others. Expressing and showing emotions that are considered authentic reinforces the experience and display of those emotions, so that they become further embedded in culture, which in turn strengthens the social training of particular emotions. The neurological foundations of this process are described above.

Attitudes toward emotions are equally enculturated. The contemporary Western culture of emotional display requires specific emotions to be exhibited in certain arenas. Just as in a consumerist society those who shop well and skillfully are rewarded, when it is emotions that are being consumed, approval goes to those whofeel or display emotion correctly. For

${ }^{51}$ Callois, Roger. Man, Play and Games. Translated by Meyer Barash. Urbana, Chicago: University of Illinois Press, 2001, 10; Huizinga, Johan. Homo Ludens: A Study of the Play Element in Culture. Boston: Beacon Press, 1950, 13. 
example, cancer patients are heralded when they face their battles with courage and cheer, not letting themselves get discouraged or depressed, or at least keeping it to themselves. It may not be easy to exhibit the correct emotion, to be upbeat and positive. It requires a lot of emotional and psychological energy to express a positive outlook and participate in entertainment culture when in pain or if your child or parent is ill. This is one of the problems that people with chronic pain face-after a short while friends and family expect them to stop talking about their pain and to 'get over it.' The same can be true of grieving. But those who are able to face the vicissitudes of life while not losing their 'spirit' are given approval, reinforcing cultural emotional values.

The determination of which emotions are considered 'correct' is culturally specific. In Western contexts someone who reports feeling that that life is fleeting and meaningless is regarded as suffering from depression, a problem to be addressed with therapy and medications (which are advertised on TV of course) so that they can feel good and have fun again. In contrast, in the Buddhist tradition this attitude would instead be considered a clear view of reality, and perhaps a sign of spiritual development:

...placed in the context of Sri Lanka, I would say that we are not dealing with a depressive but a good Buddhist. The Buddhist would take one further step in generalization: it is not simply the general hopelessness of one's own lot; that hopelessness lies in the nature of the world, and salvation lies in understanding and overcoming that hopelessness. ${ }^{52}$

This is but one example. Many more can be found in anthropological literature.

As different as these views of depression are, the disparity between religious attitudes towards emotion and contemporary Western emotional display and consumption is even more significant. Religious disciplines such as prayer or meditation aim for deepening states of experience and knowledge, dependent upon the process of emotional enculturation. These states are vastly different from the easy, shallow emotions promoted in consumer culture. In light of the neurobiological material discussed above, this is a central issue in examining consumerized emotion.

'Easy' emotions are those that require no effort, and that are simple, undemanding, and uncomplicated. Although many easy emotions are

$5^{2}$ Obeyesekere, Gananath. "Depression, Buddhism, and the Work of Culture in Sri Lanka." In Culture and Depression: Studies in the Anthropology and Cross-Cultural Psychiatry of Affect and Disorder edited by Arthur Kleinman and Byron Good, 134-52. Berkeley, Los Angeles, London: University of California, 1985, 134. 
positive ones, promoted by our cultural emphasis on fun, not all of them are. For example, TV shows and movies often evoke sentimental sadness over illness or death, and there is something satisfying about giving free rein to such sentiments. In fact it can be quite pleasurable to let the energy of a simple emotional response express itself. In contrast (staying with the example of illness and death) are the more complex emotional responses to illness and death, which may include at the same time sadness, anger, relief, guilt, and much more. These can be difficult to negotiate or reconcile.

Part of what makes emotions 'easy' is that they call on mechanical refeeling - an automatic process of the organism - and emotions are easy to manipulate because of the quality of being refelt when evoked. Advertising, greeting cards, and movie and TV producers count on this. We can come away from a show feeling good because of the release experienced from participating in the show's emotional catharsis. We can feel good about ourselves for feeling properly compassionate when that emotion is evoked by ads for support for suffering children. In (extreme) contrast is the compassion expressed by the Dalai Lama for those responsible for the Tibetan diaspora. Hardly an easy sentiment.

The commodification of emotion in consumer culture involves emotional self-expression and self-gratification as forms of consumption. But the development of religious knowledge and deeper religious states depend on the establishment of emotionally competent stimuli. In a consumerist environment, available stimuli, generated through the influence of TV, religiotainment, and so on, will be associated with entertainment, fun, easy emotions, and other experiences that feed into consumer culture. This effectively creates a feedback loop, whereby the existing emotional environment is reinforced. Further, because these emotional impulses are so easily gratified, there is little or no call to move outside of this closed circuit.

It is easier to have fun than to undergo spiritual training or practice a rigorous discipline. Concerns about religion and fun reflect the worry that religious commodification moves towards creating religious identity through consuming religious items, thus drawing people away from religious identities based in more traditional beliefs and practices such as regular attendance at worship services. ${ }^{53}$ Another aspect of this concern is that consumerized, commodified religion, religion 'lite,' discourages

\footnotetext{
${ }_{53}$ Although in 21st century America, many worship services themselves often incorporate entertainment.
} 
participation in the deeper, more difficult aspects of religious life, because these are not entertaining or fun. They aren't easy enough. The Chopra Center's "hour of enlightenment" radio show is a good example of the attempt to make a serious and even arduous spiritual development easy. Could it be that immersion in consumer culture makes it difficult or impossible to engage with demanding spiritual disciplines? This is one implication of religiotainment.

Discipline is not completely alien to consumer culture, of course. A strong work ethic or desire for profits can motivate people to discipline themselves to spend long hours at a job. And aspiring to better fitness, whether for looks or health, is a motivation for physical discipline. But both these examples result from and are oriented towards aims that are very different from those of religious disciplines. In the first example the rewards of success are economic, or at least satisfaction in the knowledge of having participated fully in the economic culture. In the second case success means a better body, 'better' being defined by the original aim of the discipline. And it should be noted that in this case the body under discussion is the naturalized body. This model is a closed system-the body is disciplined only for the sake of the physical body. There are other models for discipline of the body, derived from diverse worldviews, that reference a non-ordinary reality rather than the body itself, for example numerous religious traditions have used and still use physical pain as a means for spiritual transformation..$^{54}$

While there is discipline of emotion in the sense of a 'discipline of display,' needing to display authenticity or proper sentiment, overall consumer culture is not oriented toward discipline of emotion or development of finer levels of feeling. The structure of emotion, discussed above, through which emotions are automatically evoked, makes it very easy to create a culture of emotional consumption. What do people get out of it? They (we) feel good. Certain emotional states are quite addictive. Wave the flag and feel patriotic, read a Hallmark card and feel the simple sentiments that are expressed, watch a popular movie and feel the uplift or sadness of a romance or the release of fear and adrenalin in an action film. At the least this emotional consumption is often a form of emotional indulgence. There is social pressure as well, since if you don't express the

\footnotetext{
${ }_{54}$ Norris, Rebecca Sachs. “The Paradox of Healing Pain.” Religion 39, no. 1 (2009):
} 22-33. 
proper emotion or get adequately teary others may deem that you are disconnected or cold.

Furthermore, the energy of passion in the media and advertising promotes itself. When we see those emotions displayed we feel good and want to participate; we want to have that experience for ourselves. This response strengthens the role of those particular emotions in ourselves as well as cultural expectations regarding them. This response is similar to Max Weber's description of the attraction of charisma. In his model that attraction is to a person whose presence or experience of the here and now is experienced as an embodiment of a transcendent reality. In the here and now of media, in contrast, the promoted emotions are embedded in the naturalized body and the satisfaction of immediate gratification. Of course few of us are so uncritical that we don't have some reflexive ability in reserve, but emotion-based advertising is very powerful. After all, emotions (e-motions) move us; they are motivators. ${ }^{55}$

Nevertheless, we do have the capacities of reflexivity and intention. Not only are we capable of controlling the visible evidence of our emotions, ${ }^{56}$ but we also have the capacity to reflect on experienced emotion and, to a certain extent, control the experience in the moment and shape the direction of our emotional lives. By this I mean that humans have the ability to stand apart from their automatic reactions and restrain their impulses in the moment. This, after all, is a popular definition of courage-it is not the lack of fear, but the ability to act in spite of one's fear, to not be controlled by the automatic response. And it is the basis of much Buddhist practice: to be free from the automatic functioning of emotion (or other mental factors). The capacity to shape the development of our emotional lives is called upon by a number of religious traditions, which often note that before embarking on this path it is necessary to first be aware of one's inner life. 'Know thyself' means much more than being aware of one's personality; it calls for being conscious of one's inner and outer manifestations, the impulses and expressions that are constantly unfolding.

55 "In the context of advertising, words are not meant to communicate rational thoughts; they appeal to feeling in the same way as does visual imagery. Dramatic and highly evocative language is necessary because so much of advertising is graphic, communicating directly to the senses and emotions through images." (Bado-Fralick and Norris, Toying with God, 122).

${ }_{5}^{6}$ Barrett, Lisa Feldman, and Kristen A. Lindquist. "The Embodiment of Emotion." In Embodied Grounding: Social, Cognitive, Affective, and Neuroscientific Approaches, edited by Gün Semin and Eliot Smith, 237-62. Cambridge, New York: Cambridge University Press, 2008, 41. 
Zen mindfulness is an example of a call for this kind of inner discipline, an inward seeing that is literally 'in-sight.' Mindfulness does not mean 'thinking.' The Western equating of mind with mental (verbal) processes is not universal. Instead, mindfulness implies 'body-mind.' The process of learning mindfulness and insight includes body; body is necessary for spiritual development. Even further, discipline of body may be, in and of itself, spiritual development: "The state of mind that exists when you sit in the right posture is, itself, enlightenment." ${ }^{57}$

The view that the physical body is the means and medium of spiritual transformation is seemingly incommensurate with the materialist naturalized view of the body, yet it is our human structure, our neuroplasticity, an attribute of the naturalized body, which grants us the possibility of experiential change and development. And Eastern traditions such as Zen are not the only ones where the role of the body in spiritual development is central. Although obscured by the predominant concept of a body/soul dichotomy, it can be seen as well in Christian prayer traditions, in the role of the body in passing from the more immature stages of prayer to the more mature. As anthropologist Andrew Strathern writes:

In practice, at all stages of one's life certain new forms of hexis are adopted, a point that indicates the plasticity of people and makes it possible to accommodate the idea of change. Our bodies and minds are clearly very complex layerings of different times and kinds of learning and habit formation, and certain types of habit may be harder to discard than others, so that at any time we literally encode our own histories. But, if this is so, it also underlines the fact that we do indeed inhabit "mindful bodies" ... $5^{8}$

Mindfulness, the development of higher stages of prayer, or any other religious discipline necessarily goes against the mechanistic workings of our organism. This is what discipline means in this context, and it was and is the basis of spiritual development. Discipline requires an intentional and culturally specific education of body, mind, and emotion. By receiving impressions of particular images, and through specific bodily practices,

${ }^{57}$ Suzuki, Shunru. Zen Mind, Beginner's Mind. New York \& Tokyo: Weatherhill, 2001, 28.

${ }^{58}$ Strathern, Andrew. Body Thoughts. Ann Arbor: University of Michigan Press, 1996, 36. Medical anthropologists Nancy Scheper-Hughes and Margaret Lock also assert that the capacity for intelligent adaptation by both body and mind is evidence of our "mindful bodies" (Scheper-Hughes, Nancy, and Margaret Lock. "The Mindful Body: A Prolegomenon to Future Work in Medical Anthropology." Medical Anthropology Quarterly 1, no. 1 (1987): $6-41)$. 
the emotions can be trained to more refined feelings. ${ }^{59}$ Consumer culture, in contrast, works in the opposite direction. As discussed earlier, when certain stimuli occur the emotions associated with them recur. We are habituated to this, and for the most part see no reason not to allow this emotional mechanism to proceed as it will. This automatic functioning is similar to other body impulses such as hunger or sex. There is a pleasure in satisfying the impulse.

Consumer culture is based on bodily existence as the primary or only existence, which is the perspective of the naturalized body. Consuming, whether of goods or emotions, satisfies this body now. The attraction of colors in a display or pastries in a shop calls the senses, which can only be satisfied temporarily. Religious disciplines that deny the satisfaction of these and other desires do so with an aim that transcends the life of an individual body, but in a culture where the prevailing view of the body is materialist, there is no reason not to satisfy the immediate desires of the organism.

\section{Conclusion}

Many religious practices and images were meant to instill particular emotions and associations that led the practitioner towards more refined feeling, aiming toward a participation in something larger than the individual self. In the past, this would have meant a religious reality that transcended the mundane or in which the mundane participated in the sacred and was infused with it. The images and postures seen and taken in worship or referenced in art and culture were instrumental in creating the emotionally competent stimuli that shaped religious understanding and experience.

The concept of the naturalized body limits how we understand and experience the potential of the body and emotions to develop finer experiences. What of the mystical body of Christ, the concept of Sangha as one body, ${ }^{60}$ or Origen's 'spiritual senses'? A purely physical, materialist concept of body restricts our understanding of its potential. Paradoxically, neuroscience, although usually conceived of as materialist and reductionist, shows us some of this potential, in the structure of emotion that enables

\footnotetext{
59 For a more complete discussion see Norris, "Examining the Structure and Role of Emotion."

${ }^{60}$ Hanh, Thich Nhat. Friends on the Path: Living Spiritual Communities. Berkeley, CA: Parallax Press, 2002, 17.
} 
enculturation, and through the establishment of associated emotional stimuli. If we can avoid the materialism inherent in the neuroscientific approach it gives us a way to understand how religious disciplines made use of the process of enculturation for spiritual development.

Our emotional structure is still the same as it has been for millennia. The sensory images and bodily postures we see around us form neurological associations and shape our emotional lives, but the material that is informing that process has changed significantly. Images from Hindu mythology, embedded in a cultural history and referencing a transcendent and sacred reality, are visible everywhere in India, even when found in comic books or colorful posters. ${ }^{61}$ In contrast, in twenty-first century America we have images of fun and sensuality instead. Postures and gestures that surround us in magazines, billboards, and online are created by marketing and advertising, motivated by the need for novelty and brand recognition. Since the aim is to increase profits and market share, the development and display of these images is wholly unconcerned with bodily intelligence or mindfulness. The transcendent ideal we are enculturated into, which releases us from the mundane, stresses fun, passion, and strong but sentimentalized emotion. Transcendence of the self in a consumer culture references only the self.

${ }^{61}$ Jain, Kajri. Gods in the Bazaar: The Economies of Indian Calendar Art. Durham and London: Duke University Press, 2007; McLain, Karline. India's Immortal Comic Books: Gods, Kings, and Other Heroes. Bloomington and Indianapolis: Indiana University Press, 2009. 


\title{
EVERY STORY IS A GHOST: CHUCK PALAHNIUK AND THE REENCHANTMENT OF SUFFERING
}

\author{
Eric Repphun
}

\begin{abstract}
Whether life is worth living and when-this question is not asked by medicine. Natural science gives us an answer to the question of what we must do if we wish to master life technically. It leaves quite aside, or assumes for its purposes, whether we should and do wish to master life technically and whether it ultimately makes sense to do so. ${ }^{1}$
\end{abstract}

The worlds of the American cult writer Chuck Palahniuk are worlds haunted, even defined, by pain and suffering. Over the course of his twelve novels, Palahniuk, still perhaps best known for his 1996 debut novel Fight Club, explores the role and character of the human body in a heavily rationalized culture, and does so in a manner that makes his work a valuable site for the study of the contemporary religious landscape. Palahniuk's confrontational, controversial novels seek to revalue both brute physical pain and the more active process of suffering. They seek to remove both from strictly biomedical and therapeutic settings, at the same time recalling — though never recreating - forgotten or undervalued understandings of suffering, some of which echo traditional Christian conceptions of the transformative potential of such suffering. That being said, Palahniuk revels in ambiguity and misdirection; his attitude towards the body is profoundly ambivalent and is thus difficult to articulate clearly. At the same time that he affirms the truth of the fully rationalized understanding of the human body dominant in modern biomedicine, he rejects absolutely conventional biomedical ideas about the value of physical pain and suffering. As Rebecca Sachs Norris notes, the valuation of pain within biomedicine is narrowly prescribed within a diagnostic framework: "In Western biomedicine, pain and the suffering it entails are understood to have no value except as an indicator of a biomedical condition; pain is a

${ }^{1}$ Weber, Max. "Science as a Vocation." In From Max Weber: Essays in Sociology. Translated and and edited by H.H. Gerth and C. Wright Mills. New York: Oxford University Press, 1946, 144. 
symptom to be alleviated ... there is no framework for pain as a meaningful or transformational experience except as a necessary component of treatment or cure of the physical body... The meaning of pain or suffering is strictly utilitarian." ${ }^{2}$

In contrast to this highly instrumental view of pain, Palahniuk's novels explore and affirm the possibility that pain undertaken as an act of will represents not only a conscious rejection of the rationalization of the body but also a reclamation of agency and authenticity in a culture that has commodified the individual and turned living bodies into mere instruments. It is crucial to note at this point that pain and suffering are matters not only of individual human bodies but also of culture, making pain and suffering into an ideal site for the exploration of religion and the body. It is also essential to be clear that pain and suffering are not simple cognate terms; as Ariel Glucklich has argued: "pain must be distinguished from suffering; it is a type of sensation usually-though not necessarily-associated with tissue damage... Suffering, in contrast, is not a sensation but an emotional and evaluative reaction to any number of causes, some entirely painless." ${ }^{3}$ Nor is the line between pain and suffering clearly drawn; perhaps suffering can best be understood as an interpretive act, a 'reading' of pain; however, the individual's experience of pain, as Norris and Glucklich both note, is always already embedded within the cultural frameworks that define and delimit both the value and the range of acceptable meanings granted to the experience of physical pain. In other words, within a given cultural context, a body is expected to understand pain in certain ways and to suffer according to convention and societal norms.

Many of Palahniuk's characters, through various means-bare-knuckle boxing (Fight Club), staged automobile accidents (Rant: An Oral Biography of Buster Casey, 2007), horrific acts of self-mutilation (Haunted, 2005; Invisible Monsters, 1999; and to a lesser extent Diary, 2003 and Snuff, 2008) ${ }^{4}$-invite pain into their lives and imbue it with a transcendental,

\footnotetext{
${ }^{2}$ Norris, Rebecca Sachs. "The Paradox of Healing Pain." Religion 39, no. 1 (2009): 23.

${ }^{3}$ Glucklich, Ariel. Sacred Pain: Hurting the Body for the Sake of the Soul, Oxford: Oxford University Press, 2001, 11. Here he is referring to the official American Medical Association definition of pain as "an unpleasant sensation related to tissue damage."

${ }^{4}$ Palahniuk, Chuck. Fight Club, New York: Owl Books, 1996; Palahniuk, Chuck. Rant: An Oral Biography of Buster Casey, New York: Doubleday, 2007; Palahniuk, Chuck. Haunted, New York: Doubleday, 2005; Palahniuk, Chuck. Invisible Monsters, New York: W.W. Norton, 1999; Palahniuk, Chuck. Diary, New York: Doubleday, 2003; and Palahniuk, Chuck. Snuff, New York: Doubleday, 2008. Though there is little room to discuss them
} 
though rarely overtly religious value. Palahniuk's characters understand their pain outside of conventional structures of value and transform their pain into a form of suffering that is at the same time a rebellion against the banality and safety of a therapeutic culture that values physical pain only for its diagnostic value and which marginalizes those who seek it out. In his novels, Palahniuk gives his readers a world seemingly turned upside down, where fist fights build community, car crashes heal the damaged, physical beauty is a curse, therapy insulates people from each other and from themselves, and where self-destruction just might be the answer. To Palahniuk's credit, this inverted world is so compellingly and convincingly drawn that it becomes a tool for serious social, economic, and religious criticism. If we read them closely and with a keen eye towards his cultural context, Palahniuk's novels can be seen as important representations and even instantiations of a larger movement in modernity that I want to call 'reenchantment.'

\section{Reenchantment}

The word "reenchantment" derives its meaning from what looks to be its antonym, "disenchantment," first coined in the seminal work of the sociologist Max Weber (1864-1920) in the early days of the twentieth century. Weber's theory and concomitant narrative of "disenchantment" (Entzauberung) or "rationalization" is well known and we need not rehearse it in any detail here, though a few brief remarks are necessary for context. Put very briefly and doubtless committing considerable violence against the depth and subtlety of Weber's work: in the millennia-long process of rationalization, beginning in an imagined prehistorical world dominated by what Weber called "spirits," moving through to the rise of personified deities and universal gods, reaching its peak in ascetic Protestantism in

\footnotetext{
here, Palahniuk has published a number of other novels: Palahniuk, Chuck. Survivor, New York: Anchor, 1999; Palahniuk, Chuck. Choke, New York: Anchor, 20o1; Palahniuk, Chuck. Lullaby, New York: Random House, 2002; Palahniuk, Chuck. Pygmy, New York: Doubleday, 2009; Palahniuk, Chuck. Tell-all, New York: Doubleday, 2010; and Palahniuk, Chuck. Damned, New York: Random House, 2011. He has also published two books of nonfiction writing; Palahniuk, Chuck. Stranger than Fiction: True Stories, New York: Doubleday, 2004, and Palahniuk, Chuck. Fugitives and Refugees: A Walk in Portland, Oregon, New York: Crown Publishers, 2003; as well as a smattering of other works, including a fascinating non-fiction essay on the intersection of contemporary religion and personal narrative; Palahniuk, Chuck. "A Church of Stories." http://www.nerve.com/personalessays/palahniuk/churchofstories, accessed 6 February 2008.
} 
the American colonies in the seventeenth century, all considerations of value are gradually subordinated to considerations of function, operation, and utility. For Weber, there is a general tendency in human societies as they march towards the present to move from valuing questions of why to valuing questions of how, to move from a value-based rationality focused on the ends of action to a detached, instrumental rationality concerned only with the means.

Even if he is very often very badly misunderstood or misrepresented, Weber's work is widely known in the academic world. This need not suggest, however, that the concept of reenchantment as it is commonly used is related in any real way to his original sociological theory of Entzauberung. It is rather from commonplace (as opposed to sociological) understandings of disenchantment that the term reenchantment derives much of its immediate suggestiveness and takes on much of its meaning. This more general idea of disenchantment is, as the philosopher Charles Taylor argues, an integral part of some dominant forms of modern self-understanding, at least in the European sphere:

[O]ur understanding of ourselves and where we stand is partly defined by our sense of having come to where we are, of having overcome a previous condition. Thus we are widely aware of living in a 'disenchanted' universe; and our use of this word bespeaks our sense that it was once enchanted. More, we are not only aware that it used to be so, but also that it was a struggle and an achievement to get to where we are; and that in some respects this achievement is fragile. We know this because each one of us as we grew up has had to take on the disciplines of disenchantment, and we regularly reproach each other for our failings in this regard, and accuse each other of 'magical' thinking, of indulging in 'myth,' of giving way to 'fantasy;' we say that $\mathrm{X}$ isn't living in our century, that $\mathrm{Y}$ has a 'mediaeval' mind, while Z, whom we admire, is way ahead of her time. ${ }^{5}$

It is primarily from this understanding of disenchantment, the spirit of which Taylor captures quite nicely, that the idea of reenchantment takes its meaning, even in the academic context, where Weber's work, we would assume, is most familiar. Since the early 1970s, the idea of reenchantment has been used for a variety of purposes in a number of academic fields; however, the concept itself remains largely unexamined and its meaning is too often simply assumed. A decade ago, Harri Englund

${ }_{5}$ Taylor, Charles. A Secular Age, Cambridge, MA: Harvard University Press, 2007, 28-29. 
and James Leach described the term reenchantment as a "familiar sociological abstraction. ${ }^{\prime 6}$ Indeed, as far back as 1977, Serge Moscivici felt he could write, "It is a curious thing that the question of reenchantment is so simple. Everyone understands it at once." In reality, the question of reenchantment is anything but simple and, as an abstraction, reenchantment has been used to refer to almost anything, up to and including aspects of the process of rationalization itself.

Broadly, there exist two understandings of reenchantment in current academic and popular discourse. ${ }^{8}$ These are not mere nuances on a single concept but are in actuality two radically different conceptions of the history and character of modernity. The first, and without question the dominant account of reenchantment in contemporary academic discourse, is rooted in the simple acceptance of the commonly understood historical narrative of disenchantment. Reenchantment is here predicated on the idea that disenchantment and reenchantment are oppositional linear movements within history; the complete or near-complete disenchantment of the world is simply assumed as the background against which reenchantment takes place. Retreating to the now long-discredited logic of historical evolution, reenchantment is in this context understood as the recovery or reclamation of past enchantments. Enchantment thus becomes an either/or proposition.

However, given the serious historical and ideological problems of grand narratives of history as progress, reenchantment cannot be understood as a simple matter of the reversal or survival of enchantment; rather, it must be understood as a through-line of thought and practice that

${ }^{6}$ Englund, Harri and James Leach. "Ethnography and the Meta-Narratives of Modernity (1)." Current Anthropology 41, no. 2 (April 2000): 225.

7 Moscovici, Serge. "The Reenchantment of the World." In Beyond the Crisis, edited by Norman Birnbaum, Oxford: Oxford University Press, 1977, 142. As far as I have been able to determine, the first use of the term reenchantment in a widely available academic context can be found in Baum, Gregory. "Does the World Remain Disenchanted?" Social Research 37, no. 2 (June 1970).

${ }^{8}$ Perhaps the most visible use of the idea reenchantment outside of the academy is Thomas Moore's The Re-Enchantment of Everyday Life, Sydney: Hodder and Stoughton, 1996. For more popular uses of the word reenchantment, see also Zell-Tamis, Beverlee. The Day the Music Stopped: Re-enchantment of our Lost Spirit, New York: Carlisle Press, 2001; Crowell, Sam, Renate N. Caine and Geoffrey Caine. The Re-Enchantment of Learning: A Manual for Teacher Renewal and Classroom Transformation, Tuscon, AZ: Zephyr Press, 1998; and Crowell, Sam. "Attributes of the Heart that Reenchant Learning." Paths of Learning 16 (Spring 2003): 6-10. See also Ken Larson's novel ReEnchantment: A Schoolboys' Adventure, Bloomington, IN: AuthorHouse, 2007. 
accompanies disenchantment, even in the accelerated rationalization that characterizes modernity. Reenchantment is, in the final analysis, a dialectical counterpart to disenchantment. Reenchantment and rationalization exist in a both/and relationship that we could accurately describe as a dialectic of enchantment. By treating the question of enchantment as something rather more complex than a zero-sum game between premodern enchantments and modern rationalism, reenchantment thus understood renders the question of rationalization always already open. The disenchantment of the world and, importantly for this discussion, the human body, has never been, and can never be, complete. Where the movement of rationalization, which has clearly been dominant in many modern cultures, tends to be tidal, reenchantment tends towards more fragmented eruptions and irruptions within the larger sweep of history. The final and most radical conclusions one can draw from this understanding of reenchantment are; 1) that rationalization constantly generates its own reenchantments (and, as this is a dialectic, reenchantment constantly generates its own disenchantments); and 2) that each process is every bit as natural and every bit as characteristic of modernity as the other.

Revisiting the broad outlines of modern history, it is possible to suggest that Romanticism, which emerged as a counterpart to Enlightenment rationality, is an early iteration of reenchantment; indeed, the logic reenchantment suggests that Romanticism cannot be understood as an anomalous and insignificant anti-rational and anti-modern movement. Quite to the contrary, Romanticism and its reenchantments have played a crucial role in modernity, as Taylor suggests: "These two big and many-sided cultural transformations, the Enlightenment and Romanticism with its accompanying expressive conceptions of man, have made us what we are...We are still visibly working out their implications or exploring possibilities which they opened up for us." It is worth recalling here that Weber borrowed the very phrase "disenchantment of the world," from Friedrich Schiller, an important figure in German Romanticism who, in his 1788 poem "Die Götter Griechenlandes" ("The Greek Gods"), speculated that the gods driven out of the world by monotheistic religion and modern rationality had taken refuge in Romantic poetry. There is in fact a good deal of similarity between what Schiller stated poetically and what Weber

\footnotetext{
9 Taylor, Charles. Sources of the Self: The Making of the Modern Identity, Cambridge: Harvard University Press, 1989, 393.
} 
argued sociologically; indeed, it is possible to situate Weber's work firmly within what Edward Shils calls "German sociological romanticism."

\section{Reading Chuck Palahniuk}

Put as bluntly as possible, Chuck Palahniuk is a Romantic. He posits through his novels a world that is reenchanted in what we will see is a radically embodied fashion. Few of Palahniuk's leading characters escape incredible physical trials or extreme bodily humiliations; indeed, the frailty and endless malleability of the human body are arguably the most important recurring themes across Palahniuk's work. What brings this into the realm of reenchantment is that these characters search for ways to understand their pain in ways quite outside the conventional, rationalized logic of contemporary biomedicine. Quite against the prevailing view that Romanticism and reenchantment must be matters of unvarnished sunshine and light, Palahniuk's work is confrontational, multivalent, and very, very bloody, calculated to invite controversy and even provoke anger. It is apparent that Palahniuk sees in the shocking nature of his work a serious, even parabolic purpose:

I don't even think of it as shock value. I just do not want to waste my time and I do not want to waste the reader's time by discussing something that is not really, really confronting and really challenging. You know, if you're going to go into one of my stories, you're gonna' come out the other end a slightly different person and not entirely comfortable in the world anymore. And, so, I just find it impossible to sit down and write a story that does not go some extreme place because that's the entire purpose of a story for me. ${ }^{11}$

In an interview, he stated simply: "I'm not a nihilist. I'm a romantic. All my books are basically romances; they're stories about reconnecting with community."12 Odd as this assertion may seem on the surface, there is

10 Shils, Edward. "Daydreams and Nightmares: Reflections on the Criticism of Mass Culture." Sewanee Review 65 (1957): 598. Schiller's original phrase was "die entgötterte Natur"-literally, the "disgodding" of nature-which Weber later transformed into "die Entzauberung der Welt." For the full text of Schiller's poem, see Schiller, Friedrich. Gedicte von Friedrich Schiller. Interpretationen, edited by Norbert Oellers, Stuttgart: Philipp Reclam, Jr, 1996, 64-83.

${ }^{11}$ Palahniuk, Chuck. "The Agony Column Interview Archive, 20 May 2005." Available at http://trashotron.com/agony/audio/chuck_palahniuk_2005.mp3, accessed 11 February 2008.

${ }_{12}$ Williams, Laura J. "Interview: Knock Out: The Writing of Chuck Palahniuk has More than Just Hipster Cred.” http://www.annarborpaper.com/content/issue24/palahniuk_24 .html, accessed 6 February 2008. 
ample precedent in the long Romantic tradition for figures like Palahniuk, whose work is permeated throughout with darkness and with a palpable sense of absence. Thomas McFarland writes, "the pervasive longing of the Romantics for an absent reality was at the same time an index to a prevailing sense of incompleteness, fragmentation, and ruin. ${ }^{{ }^{13}}$ Similarly, Jerome J. McGann argues that many "works widely acknowledged to be Romantic are nihilistic, desperate, and melancholy." ${ }^{14}$

Like that of even the earliest Romantics, Palahniuk's work also can be seen as a fiction of protest. What makes Palahniuk such a valuable source for the study of contemporary religion is the simple fact that one of the things that Palahniuk is most interested in critiquing is rationalization and its tendency to reduce every calculation of value to a brutal and inhuman logic of exchange value and utility. Palahniuk emphasizes, even more than Weber, the dehumanizing aspects of disenchantment. The banality and commodification of everyday life is the catalyst for much of what happens in Palahniuk's novels, where his characters go to drastic lengths to find a life, in the words of Diary's narrator, "Where every day doesn't start with an alarm clock and end with the television. ${ }^{{ }^{15}}$ It is fitting, then, that Palahniuk draws his characters from the fringes and gutters of contemporary society. Even though many of them come from largely comfortable middle-class backgrounds, Palahniuk's characters are the literally damaged and very often the physically afflicted. They are the sick, the addicted, the haunted, the downtrodden, the disaffected, the compulsive, those that mainstream American society deems as useless. He flirts with stereotypes of uselessness and at the same time subverts them by presenting his marginal characters as complex and often deeply moral figures. Palahniuk's choice to focus on marginal, pathetic, and occasionally repellent characters thus serves as a way to force a confrontation with the dominant modes of valuation within society.

Reading Palahniuk through the lens of reenchantment is not meant to imply that he offers any traditional or orthodox religious views of the world. It is also a mistake to equate religion, as it is commonly understood, with reenchantment—and Weber, we must remember, explicitly included

\footnotetext{
${ }^{13}$ McFarland, Thomas. Romanticism and the Forms of Ruin: Wordsworth, Coleridge, and the Modalities of Fragmentation, Princeton: Princeton University Press, 1981, 11.

${ }^{14}$ McGann, Jerome J. The Romantic Ideology: A Critical Investigation, Chicago: The University of Chicago Press, 1983, 23.

${ }_{15}$ Palahniuk, Diary, 9.
} 
both the emergence of radically transcendent monotheistic gods and John Calvin's doctrine of predestination as important steps in his narrative of disenchantment. Despite this, in the interests of context, it will perhaps be helpful to make some very general comments about Palahniuk's treatment of religion, which is, like so many other aspects of his work, deeply ambiguous. Though there is a good deal of religious language throughout his books, borrowed mainly from Christian and Buddhist vocabularies, Palahniuk's attitude toward traditional forms of religion is alternately dismissive and respectful. Palahniuk's fullest treatment of contemporary religion comes in his novel Survivor (1999), which weaves together a satire of televangelism and a critique of how media spectacle turns everything, human bodies and religions included, into fungible forms of capital. A more specific example, from the novel Choke, which chronicles the life and times of Victor Mancini, is characteristic of Palahniuk's use and treatment of religion. The novel closes as Victor and his friend Denny begin to build a nameless structure on a piece of urban wasteground. They have, by their own admission, no plans, no final vision of what they are building. The news media, having discovered this strange spectacle, nonetheless decides that what they are building must be a church, which throws Victor into a rage: “It's pathetic how we can't live with the things we can't understand. How we need everything labeled and explained and deconstructed. Even if it's for sure unexplainable. Even God. 'Defused' isn't the right word, but it's the first word that comes to mind." ${ }^{m 6}$ The novel ends with a telling moment that brings together all of the novel's thematic strands together in a surprising juxtaposition that highlights the way all these threads connect, one of Palahniuk's favorite literary devices:

We can spend our lives letting the world tell us who we are. Sane or insane. Saints or sex addicts. Heroes or victims. Letting history tell us how good or bad we are. Letting our past decide our future. Or we can decide for ourselves. And maybe it's our job to invent something better... It's creepy, but here we are, the Pilgrims, the crackpots of our time, trying to establish our own alternate reality. To build a world out of rocks and chaos. What it's going to be, I don't know. Even after all that rushing around, where we've ended up is in the middle of nowhere in the middle of the night. And maybe knowing isn't the point. Where we're standing right now, in the ruins in the dark, what we build could be anything. ${ }^{17}$

16 Palahniuk, Choke, 232.

${ }_{17}$ Ibid., 292-293. 
What Palahniuk seeks to do here is to give the reader something that does not yield to common language: Victor and Denny are not building a church; they are building something without a name. For Palahniuk, this difference is everything. Perhaps all of Palahniuk's work can be best understood as an ongoing search for places and things that are beyond instrumentality, calculation, or the boundaries of ordinary language, including the language of modern medicine.

\section{Chuck Palahniuk and the Reenchantment of Suffering}

Palahniuk confronts the reader with a view of the world where physical pain has an intrinsic if indefinable value quite outside the operational, diagnostic role that it is given in many areas of modern biomedicine. Palahniuk's work explicitly draws distinctions between willed and unwilled pain, between pain understood as valuable and pain explainedand explained away — with operational medical language. Before moving on to this aspect in Palahniuk's work, perhaps some brief comments are needed for context, beginning with a fundamental, yet often overlooked, truth: pain is not a simple matter of bodies and bone and blood and nerve endings, but is also a matter of enculturation, as both Glucklich and Norris have already noted. Similarly, historian Roselyne Rey writes:

Pain is indeed certainly a combination of cultural and social factors: it has not had the same significance throughout the ages nor in the various differences in civilizations... Moreover, pain involves a codified form of social behavior which sets the parameters of allowable overt manifestations and regulates the expression of such innermost personal experiences...Pain's expression, whatever form it takes, does not escape the dialectic concerning what must be concealed and what may be revealed. ${ }^{18}$

Rey argues further that suffering in the Western world has been heavily influenced by Christian conceptions of pain and suffering: "The belief in the redeeming virtues of pain, the idea that suffering individuals were closer to Christ, that their anguish could be offered up in penitence for earthy sins, or even that God put only his elected few through terrible trials were all recurrent themes throughout Church literature." ${ }^{19}$ In a study of contemporary literature, Robert Detweiler, who attaches a great

${ }_{18}$ Rey, Roselyne. The History of Pain. Translated by J.A. Cadden, Louise Elliott Wallace, and S.W. Cadden, Cambridge, MA: Harvard University Press, 1998, 2-4.

19 Ibid., 184. 
deal of importance to pain and suffering, puts it even more simply, "The pain of the crucifixion retains its power to affect us emotionally and is still at the heart of the Western sense of the sacred. ${ }^{20}$ Over and against this long history of competing interpretations of pain and as a result of the dominant trend towards naturalism in biomedicine, physical pain in the Western world is today largely understood in a medical and therapeutic manner. Anthropologist Talal Asad notes that this has serious consequences on a cultural and individual level:

There is a secular viewpoint held by many (including anthropologists) that would have one accept that in the final analysis there are only two mutually exclusive options available: either as agent (representing and asserting himself or herself) or a victim (the passive object of chance or cruelty). When we say that someone is suffering, we commonly suppose that he or she is not an agent... Yet one can think of pain not merely as a passive state (although it can be just that) but as itself agentive. Physical pain is of course the object of passion-but also of action..$^{21}$

What Asad points to here is that, outside of a rationalized, medicalized understandings, pain can take on deeper resonances and be transformed into authentic expressions of suffering. Norris goes as far as to suggest, as Palahniuk ultimately does, that narrow, instrumental understandings of pain can themselves lead to increased suffering:

The experience of pain is a subjective, enculturated experience; the meaning that pain or suffering holds within a given cultural context affects the experience of pain and suffering. In a context where pain and suffering are not understood to have value, that attitude can create more suffering, even in conditions means to alleviate suffering, such as in biomedical situations. In contrast, where pain and suffering are understood to be valuable, such as within a religious context, those experiences can be used for spiritual transformation; the liminal state that pain can induce contributes to this process. ${ }^{22}$

Though outside of conventional religious contexts, Palahniuk's characters transform the pain they invite into their bodies into a willed, positive form of suffering understood as a rebellion against the banality and safety of the therapeutic culture that both rejects pain and marginalizes

\footnotetext{
${ }^{20}$ Detweiler, Robert. Breaking the Fall: Religious Readings of Contemporary Fiction, San Francisco: HarperCollins, 1989, 46-47.

${ }^{21}$ Asad, Talal. Formations of the Secular: Christianity, Islam, Modernity, Stanford: Stanford University Press, 2003, 79.

${ }^{22}$ Norris, "Paradox", 22.
} 
those who seek it out. These people, fictional though they may be, are not anonymous Christians or closeted religious believers, but they also cannot be divorced from the long and highly complex history of the interconnections of modern medicine, the human body, and religious practice in the Western world. Though they do not intend in any way to re-enact traditional Christian imaginaries of pain, Palahniuk's characters understand pain in ways that are rooted in this long cultural tradition, even if these roots remain buried rather deeply under the surface. Recalling Asad's assertion that embracing pain can be a potent form of agency, we also get a glimmer as to the ways in which Palahniuk's reenchantment of suffering is quite radically subversive in a culture where naturalistic biomedical understandings of the body remain dominant. In fact, this reenchantment can be seen as a reaction against and a resistance to the thoroughgoing naturalism of contemporary medicine, a perfect example of the way that reenchantment can grow quite naturally out of rationalization.

The scission between an instrumental and a reenchanted understanding of the body is perhaps most clearly evident in the role of medicine and medical language in Palahniuk's novels. Technical biomedical language mediates the authentic experience of pain in Palahniuk's worlds; operational medical language is most often portrayed as a buffer between the embodied individual and what is meaningful, even what is real. In Haunted, the story of a writer's retreat gone very, very wrong, Miss Leroy, before recounting a horrific story about a man who falls into a geyser, distances herself from his pain with technical language: the narrator recounts, "It's poetry to hear Miss Leroy spin this out. Skeletonization. Skin slippage. Hypokalemia. Long words that take everybody in the bar to safe abstracts, far, far away. It's a nice little break in her story, before facing the worst. You can spend your whole life building a wall of facts between you and anything real. ${ }^{{ }^{2} 3}$ Palahniuk makes a similar point about support groups and the whole of contemporary therapy culture, which some scholars have significantly identified as a crucial part of the religious milieu of the New Age. ${ }^{24}$ The narrator of Fight Club says of the distancing

${ }^{23}$ Palahniuk, Haunted, 338.

${ }^{24}$ Eduardo Mendieta, writing of Palahniuk's work, argues, "This twelve-step is in fact an ersatz religion. In it we find ritual, rhythm, and solace from the uncertainty of an overwhelming world turned strange by the monotony of its endless changing. In it we find prayer, and confessions, we find saints and martyrs." Mendieta, Eduardo. "Surviving American Culture: On Chuck Palahniuk." Philosophy and Literature 29, no. 2 (October 2005): 6 . 
effects of the therapeutic ethos as embodied in the support group: "At Above and Beyond, we start with the Catch-Up Rap. The group isn't called Parasitic Brain Parasites. You'll never hear anyone say 'parasite' ... No one will ever say parasite. They'll say, agent. They don't say cure. They'll say, treatment." ${ }^{25}$

Over and against such therapeutic and linguistic attempts to define the parameters of pain and suffering, over and against the biomedical reduction of pain to a mere symptom, Palahniuk provides a number of examples of forms suffering that are both reenchanted and which recall, if unconsciously, traditional Christian understandings of the value of suffering. He does this primarily by creating fictional economies of exchange that involve a good deal of often vividly described physical pain and bodily violation. The two novels that offer the most fully realized examples of such economies of suffering are Fight Club and Rant. What is exchanged in both of these narratives is the authentic experience of sometimes extreme physical pain and there are, not coincidentally, distinct similarities between the two narratives. Both novels tackle the theme of alienation and the perceived lack of meaningful experience and narrative in the contemporary world. Both narratives revolve around the charismatic leader of an antisocial subculture. Both involve willed acts of suffering through the conscious creation of two events that the vast majority of people in contemporary culture strive to avoid: fist fights and car crashes.

The narrator of Fight Club is typical of Palahniuk's protagonists; he is afflicted with insomnia, bored with his life and deeply alienated from the lives of others. His work as a "recall coordinator" for a major auto company, which involves the callous calculation of the monetary value of individual human bodies, implicates him directly in the ongoing process of rationalization and the dehumanization that so often accompanies it. ${ }^{26}$ As a way out of his disaffection, the narrator unknowingly manifests a charismatic alter ego named Tyler. The two men-the novel and later film

\footnotetext{
${ }_{55}$ Palahniuk, Fight, 35. Emphasis in original.

${ }_{26}$ The narrator describes his work thusly: "Wherever I'm going, I'll be there to apply the formula. I'll keep the secret intact. It's simple arithmetic. It's a story problem. If a new car is built by my company leaves Chicago travelling west at 60 miles per hour, and the rear differential locks up, and the car crashes and burns with everyone trapped inside, does my company initiate a recall? You take the population of vehicles in the field (A) and multiply it by the probable rate of failure (B), then multiply the result by the average cost of out-ofcourt settlement $(C)$. A times B times $C$ equals $X$. This is what it will cost if we don't initiate a recall. If $X$ is greater than the cost of a recall, we recall the cars and no one gets hurt. If $\mathrm{X}$ is less than the cost of a recall, then we don't recall." Palahniuk, Fight, 30.
} 
adaptation both treat the narrator as two separate people-form "fight clubs" in order to offer other men - and only men - an opportunity for the mutual exchange of willed suffering through the blunt instrumentality of bare-knuckle fist fighting. Physical pain, transformed into a specific and liberatory form of suffering, is the primary vector for authentic experience and personal transformation throughout the novel. During a pivotal scene, Tyler deliberately, viciously burns the narrator's hand, driving home through violent means that pain is in itself the marker of authenticity: Tyler tells the narrator, "This means something". ${ }^{27}$ Tyler tells him, "This is greatest moment of your life. ${ }^{28}$ At the end of the scene, the narrator takes his burning hand from Tyler and submits to the pain, turning what was an act of violence into an act of will, turning an act of violation into an act of agency. In the starkest possible terms, the narrator here takes hold of the physical sensation of pain and willingly transforms it into a form of suffering that is deeply subversive of conventional logics on the role and value of pain.

Significant for our purposes here, the narrator describes the experience of fight club with religious language: "There's hysterical shouting in tongues like in church, and when you wake up Sunday afternoon you feel saved." ${ }^{29}$ Drawing connections between Palahniuk's use of religious language and his overarching critique of rationalized contemporary language, this willed suffering is also a rupture of the closed system of language: "What happens at fight club doesn't happen in words ... You aren't alive anywhere like you're alive at fight club ... Fight club isn't about winning or losing fights. Fight club isn't about words. ${ }^{3^{\circ}}$ It is important here to underline that fight club is about exchange as well as experience; fighting in the novel must be understood as a relational act. Going back to the framework of analysis that Weber provides us with, in economic and utilitarian terms, such an exchange of suffering is useless, even wasteful in that it puts to non-instrumental use bodies that could more profitably and usefully applied elsewhere. Writing of David Fincher's 1999 visionary film adaptation of Fight Club, Stephanie Remlinger notes this in relation to the wounding of the body: "they [the characters' wounds] are signs of protest as well as real damages to the 'body economic' ... Through hurting

\footnotetext{
${ }^{27}$ Ibid., 77.

${ }_{28}$ Ibid., 77.

29 Ibid., 51.

$3^{0}$ Ibid., 51.
} 
themselves the men destroy human capital, they refuse to be of service or to function efficiently." ${ }^{31}$

Rejecting the roles assigned to them and refusing to be identified only by their function, the men at fight club offer a serious challenge to a system overwhelmingly and inhumanely concerned with operation. They articulate their critique on, by, and through their own bodies. Such corporeal forms of resistance have a long and interesting history in the Western context, again tied to matters of religion. This history, for example, includes the cult of the saints in early Christianity, many of whom, as Rodney Stark notes, were martyrs, those who often willingly offered their bodies in the name of their religion. In this context, Stark also very astutely points out that the medicalization of pain carries over into the discourses about the willed embrace of suffering:

Clearly, the voluntary surrender of one's self to the experience of martyrdom, when it was known that the most exquisite tortures were involved, is prima facie evidence of the presence of the tendency towards masochism... [F]rom the beginning, social scientific studies of religion have been shaped by a single question: What makes them do it? How could any rational person make sacrifices on behalf of unseen supernatural entities? The explicit answer to this question nearly always has been that religion is rooted in the irrational. ${ }^{2}$

Though it may seem to be tangential to the current discussion, it is worth noting that the case of martyrs in earliest Christianity (at least on Stark's compelling calculus), offers an intriguing example of the ways in which instrumental concerns - the growth and legitimization of the

$3^{31}$ Remlinger, Stefanie. "Fight Club: The Most Dangerous Movie Ever?" In The Aesthetics and Pragmatics of Violence, edited by Michael Hensen and Annette Pankratz (Passau: Verlag Karl Stutz, 2001), 147. It is worth noting that there are a number of other critics and commentators who have pointed to the connection of suffering and the religious in Fight $C l u b$, either the novel or the film, which has generated a good deal more secondary source material. Christopher Deacy calls Fincher's film a "potent religious parable" and argues, "Fight Club posits that there is something potentially liberating-even, indeed, salvific-in the use of violence. For, it is suggested, violence has the capacity to provide its practitioners with the vehicle and the agency of defining one's self and of ultimately being able to connect and integrate with other individuals in an otherwise affectless and estranged society." Deacy, Christopher. "Integration and Rebirth through Confrontation: Fight Club and American Beauty as Contemporary Religious Parables." Journal of Contemporary Religion 17 (2002): 62. Similarly, Peter Mathews concludes simply that "Fight club becomes the new religion without religion.” Mathews, Peter. "Diagnosing Chuck Palahniuk's Fight Club." Stirrings Still 2, no. 2 (Fall/Winter 2005): 92.

$3^{2}$ Stark, Rodney. The Rise of Christianity: A Sociologist Reconsiders History (Princeton: Princeton University Press, 1996), 166. 
early church-can grow directly out of more value-oriented concerns such as the willing self-sacrifice of valued individual believers. That such a waste of valuable human resources can come to have a value that is highly instrumental demonstrates the ways in which rationalization and reenchantment can interpenetrate, each emerging out of and mingling with the other. The same is true in far more contemporary emergences of bodily resistance and subversion.

Palahniuk's novel Rant, adopting the multiple perspectives of an oral biography, tells the story of one Buster "Rant" Casey, a supernaturally gifted small-town boy who makes his way to the city, disrupts the dominant social order, and threatens to destroy the very fabric of time itself. Rant is in many ways a companion piece to Fight Club, which was published more than a decade earlier. If anything, Rant is an even more radical critique of contemporary culture than Fight Club and is even more relevant to Palahniuk's reenchantment of suffering, given that the whole of the narrative hinges on the ways in which members of a subculture react to the pervasive rationalization that surrounds them. In many ways, Rant is a novel unstuck in time. The novel is set in the near future, or, as the narrative hinges on the science fiction trope of time travel, an alternate present.

Rant, like Tyler in Fight Club, seeks out authentic, unmediated experience, often in the form of physical pain, again transforming suffering into an act of agency rather than one of victimization. Rant spends his childhood in Middleton obsessed with getting bitten by animals. The pain is, for Rant, an antidote for the pervasive mediation of contemporary life. A childhood friend recalls an incident where the two boys go out hunting recklessly for bites: "Both of us trickling blood out of the little holes in our hands and feet, watching our blood leak out in the sand under the hot sun, Rant says, 'This here,' he says, 'far as I'm concerned, this is how church should feel." " ${ }^{33}$ Moving from Middleton to an amorphous, unnamed American city, carrying with him a virulent strain of rabies contracted from so many animal bites, Rant stumbles upon a subculture of people involved in something they call "Party Crashing," which involves teams of people in cars deliberately crashing into each other, which unavoidably involves some physical pain. Party Crashing, regulated by an elaborate system of rules meant to ensure that only those involved in Party Crashing run into each other and no one outside the culture is injured,

\footnotetext{
33 Palahniuk, Rant, 76.
} 
is the primary method in the novel for generating authentic, meaningful experience.

Green Taylor Simms, a highly ambiguous character who is given much of the novel's expositional duty, argues that such deliberate car crashes are both deeply subversive acts within the highly rationalized realm of traffic control, and are also a renegotiation of an established set of values:

Perpetuating Santa Claus and the Easter Bunny breaks ground for further socialization-including conformance to traffic laws which allow the maximum number of drivers to commingle on our roadways. In addition, insisting the journey is always a means to some greater end, and the excitement and danger of the journey should be minimized. Perpetuating the fallacy that the journey itself is of little value... The activity casually known as Party Crashing rejects the idea that driving time is something to be suffered in order to achieve a more useful and fulfilling activity. ${ }^{34}$

Again, in the logic of the dialectic of enchantment, we can see Party Crashing as a subversion of dominant systems of valuation through the deliberate violation of the economic and utilitarian value of the traffic network, designed as it is for efficiency, predictability, and protecting drivers as much as possible from the possibility of physical harm. Palahniuk's characters relate the experience of Party Crashing, like that of fight club, directly to religious experience. Rant's girlfriend Echo Lawrence recalls: "But anytime Rant had an orgasm, or the moment after we'd been rammed by another team, right when he blinked his eyes and seemed to realize he wasn't dead, he'd smile and say the same thing. At that moment, Rant would always smile, all dopey, and say, 'This is what church should feel like.' "35 Several other informants in the novel relate the experience of being in an auto accident to a liminal, even religious experience, following Victor Turner's well-known theory of ritual (indeed the novel quotes from Turner's classic The Ritual Process).${ }^{36}$ Simms explains the connection:

In a car accident, you slow down to dream time. Time gels or freezes until you can recall every moment of every moment of every moment... Common to almost all spiritual beliefs is the idea of Liminal Time. To ascetics, it can be the moment of greatest suffering. To Catholics, it's the moment the

\footnotetext{
34 Ibid., 131-132.

35 Ibid., 215 .

${ }^{36}$ See Turner, Victor. The Ritual Process: Structure and Anti-Structure, New York: Aldine de Gruyter, 1969, particularly chapter three, "Liminality and Communitas," 94-130; and, to a lesser extent chapter five, "Humility and Hierarchy: The Liminality of Status Elevation and Reversal," 131-165.
} 
Communion wafer is presented to the congregation. The moment is different for each religion or spiritual practice, but Liminal Time itself represents a moment in which time stops passing. The actual definition is a moment "outside of time." That moment becomes the eternity of Heaven or Hell, and achieving even an instant of Liminal Time is the goal of most religious rituals. In that moment, one is completely present and awake and awareof all creation. In Liminal Time, time stops. A person is beyond time. Being involved in an automobile accident has brought me closer to that enlightenment that any religious ritual or ceremony in which I've ever participated. ${ }^{37}$

Party Crasher Neddy Nelson also finds something of the religious in the subculture: "Haven't oppressed people always gone to church for comfort? There, didn't they meet other oppressed people? Haven't all major revolutions brewed as people complained together and sang songs and got riled up to take violent action? Was Party Crashing our church, the way people came together?" ${ }^{8}$ Here Neddy recognizes that what he is doing is in some way truly subversive, that the pain he incurs while Crashing has meaning. In Rant the power of this kind of ruptural-and always physicalexperience is such that it can grant immortality or allow anyone who is able to remain willingly in Liminal Time to travel through time. ${ }^{39}$ Here we can see that the power of such experience, intertwined as it is with bodily harm and suffering, is raised to the realm of an enchantment that is able to fundamentally alter the shape and direction of the known world. Here the reenchantment within Palahniuk's world becomes strikingly literal.

\section{Inauthentic Suffering}

However, this does not mean that Palahniuk's work values all pain equally or that his novels present all suffering as authentic suffering. Just as there are numerous examples of the potentially positive effects of physical

37 Palahniuk, Rant, 213-214.

${ }^{38}$ Ibid., 228.

39 Simms goes as far as to claim that by entering into a permanent Liminal Time, he and others involved in Party Crashing will attain immortality: "Throughout all mythology, the gods have created themselves as mortals by bearing children by mortal women ... The infinite made finite. It's when you cross this mythology with the Grandfather Paradox that the reverse occurs and mortal flesh might be made divine... the time traveller eliminates his physical origins, thus transforming himself into a being without physical beginning and therefore without end. Simply stated: a god... In a somewhat hideous parody of the Annunciation, the time traveller would make a pilgrimage to a direct ancestor, ideally the traveller's mother or father, at a time before the traveller's conception-for the purpose of killing that ancestor." Palahniuk, Rant, 265-267. 
pain, his critique of consumer society, steeped as it is in the comparison of authentic and inauthentic experience, is perhaps even more reliant on the depictions of inauthentic suffering. Haunted, in many ways the most difficult of Palahniuk's novels, hinges on the abuse of the authentic experience of pain, of pain as interpreted in bluntly economic, highly instrumental ways. Haunted represents the working out of the opposition between authenticity and commodification in the form of a novel that is at turns funny, chilling and bluntly confrontational. The novel is a collection of short stories and free-verse poems couched in the narrative framework of a writer's retreat where nineteen aspiring writers gather in a rented theatre where they will be locked for three months to allow them to write without distraction. Each of the characters is given a chance to tell their story to the others, and it is these stories that make up the bulk of the novel, by far Palahniuk's longest. Each of the characters is given a name based on their story and it is only rarely, and by accident, that these people's real names are revealed to the reader. Even by the generous standards one must adopt in relation to Palahniuk's corpus, the stories in Haunted are shocking, involving any number of humiliations, mutilations and violent, self-destructive acts; however, in this instance, pain is actively turned into a commodity and is thus stripped of its meaning.

The desire for learning to be better writers, for catharsis and for creating community are quickly abandoned as the inmates set out to experience the retreat with an eye to the potential sale of their stories and the celebrity they imagine will follow from publication and broadcast of these stories. They begin to craft their own actions and reactions to follow the conventions of an increasingly confessional mass media and an increasingly therapy-obsessed culture:

Already in out minds, here in the red-and-yellow fake firelight, we could picture the future: the scene of us telling people how we'd taken this little adventure and a crazy man kept us trapped in the old theatre for three months. Already we were making matters worse. Exaggerating. We'd say how the place was freezing-cold. There was no running water. We had to ration the food..$^{40}$

In the beginning, none of these things are actually true as the theatre has ample food, water, and comfort, but as the narrator, whose identity is never revealed, confides, "our own story will have to get a lot more dramatic before it would be worth selling. We need everything to get

\footnotetext{
40 Palahniuk, Haunted, 84.
} 
much, much worse before it's over."41 To ensure this happens, the characters engage in an increasingly violent orgy of self-destruction, ruining the food supply, wrecking the washing machine and the heating system, in the end resorting to cannibalism of the bodies of those who have died (or in one memorable incident, someone who had merely passed out) in the interest of suffering, but of suffering in recognizable, marketable ways. Like the protagonists in Rant and Fight Club, the people in Haunted invite all kinds of pain on themselves, which leads to a grim, hyperbolically violent, and perversely funny game of one-upmanship: "Whoever can show the worst suffering, the most scars, they'll play the lead in the public mind." ${ }^{42}$ The Duke of Vandals dies while exercising to further accentuate his self-induced starvation. The Reverend Godless violates himself with the splintered wooden leg of a broken chair. The Earl of Slander chops off his own fingers, Chef Assassin his toes, the Matchmaker something more intimate, resulting in his death.

The tragedy of Haunted is that some of the stories the inmates tell each other are compelling, genuine acts of communication and even expiation that get lost in the desperate need to make the story of the retreat into something easily sold, painlessly digested, and then quickly forgotten. In a precise reversal of the economics of fight club, here we find a group of people being ruthlessly converted to human capital or, even more disturbingly, ruthlessly converting themselves into human capital, reducing themselves through painful means into mere instruments. With the striking juxtaposition of the genuine suffering that takes place in some of the inmates' stories and that of the inmates themselves, Palahniuk implies that, though in a very different sense, their pain is as instrumental and as rationalized as that described by modern scientific medicine. Their pain here becomes merely the means to an end, a way to cure their symptoms, which are, in this context, cultural rather than biological. In a parallel fashion to the way that physical pain is valuable in modern biomedicine only as a way to diagnose and solve larger problems, in Haunted, much of the pain that is endured is seen as a way to solve the problems of poverty, alienation, and social invisibility.

Against all this clamoring for attention, Palahniuk allows the reader the occasional flickering glimpse of suffering with meaning. In Haunted, true suffering is suffering that silences, that resists language, resists codifica-

\footnotetext{
${ }^{41}$ Ibid., 86.
}

${ }^{42}$ Ibid., 147. 
tion or easy characterization. Importantly for the purposes of this volume, true suffering in Haunted is enacted bodily, though the medium of willed physical pain. Intriguingly, what Palahniuk characterizes as inauthentic suffering, as we can see above, is also enacted on and through the body. The difference between instrumental uses of pain and more enchanted uses of pain, then, is all in the ways that such experience is initiated and interpreted by those who undergo such experiences. The novel makes this point through the metaphoric device of the "Nightmare Box," a recurrent artifact in the stories of Mrs. Clark, which involve the disappearance and eventual death of her fifteen-year-old daughter, aptly named Cassandra. At an art gallery, Cassandra catches a glimpse of "real reality" contained within the Box, which drives everyone who looks into it to madness; after first looking into the Nightmare Box, Cassandra withdraws from the world and allows her body to waste away to the point of death. The Nightmare Box underlines the need for the world to be sharable by presenting its victims with something so singular it defies description:

What's inside the box is some fact you can't unlearn. Some new ideas you can't undiscover... Plus, only one person can look each time. What you suffer, you suffer it alone. What happens inside the Nightmare Box, it only happens to you. There's no one you can share it with. There's no room for someone else... What's in the box is proof that what we call life isn't. Our world is a dream. Infinitely fake. A nightmare. One look... and your lifeyour preening and struggle and worry-it's all pointless. ${ }^{43}$

The Nightmare Box offers Cassandra authentic experience because it is unmediated, esoteric, and impossible to articulate. This singular experience has an immediate effect; mere days after her journey into the Nightmare Box, Cassandra disappears, only to turn up walking down the highway months later, naked and covered with blood. She is horribly mutilated, missing fingers, teeth, toes, and all of her fingernails. The story

\footnotetext{
43 Ibid., 222. This has an intriguing analogue in Palahniuk's non-fiction; he writes: "Oh, I'd love to believe in an invisible world. It would undermine all the suffering and pressure of the physical world. But it would also negate the value of the money I had in the bank, my decent house and all my hard work. All our problems and all our blessings could be readily dismissed because they'd be no more real than plot events in a book or movie. An invisible, eternal world would render this world an illusion... I have no experience with it, so I am unable to take it seriously. It will always seem like a joke. There are no ghosts. But if there are, my dad should damn well tell me himself." Palahniuk, Stranger, 115. This statement, however, falls at the end of a disconcerting story about a haunted house and the possible visitation of the spectre of Palahniuk's father, who was murdered in 1999. See "The Lady" in Palahniuk, Stranger, 109-115.
} 
slowly reveals that all of her wounds are self-inflicted, as is her weight loss and the effects of months of exposure, which baffles Cassandra's mother and the police, all of whom demand a more satisfactory explanation for her wounds.

That such suffering was an act of agency and will is, for the rest of the characters in the story, simply incomprehensible, as Norris, Asad, and others claim is true also of modern medicine. From the first, the only answers Cassandra can give to questions about her experience are negative: "I don't know... I can't say." ${ }^{\prime 4}$ Even more importantly in the context of the writer's retreat and its orgy of self-aggrandizement, Cassandra tells her mother after her ordeal, again underlining that there are different kinds of suffering, which Palahniuk again differentiates by reference to language: "I'm not like you anymore... I don't need to brag about my pain." ${ }^{45}$ Even after she is found dead, apparently at peace, in the woods, Palahniuk continues this conjunction of corporeality and silence, giving the reader a detailed, pages-long, clinical description of her body as it begins to decay on the forest floor, left as bait by the police to attract what they assume will be the person who killed her, because the police simply cannot accept that anyone would willingly inflict such extremes of suffering on themselves. Even in death, Cassandra's pain remains inarticulate, impossible to understand within conventional logics of value, especially the clean, clinical logic of biomedical language that Palahniuk evokes in his description of Cassandra's slow but oddly triumphant decay.

Cassandra's tale suggests that there are further levels of reenchantment that even shared experiences of suffering like fight clubs or Party Crashing cannot reach and that the truest enchantments are those that demand nothing less than silence. Cassandra's mother invokes religious language to attempt to understand her daughter's suffering: "She sat through every day ... they way people sit in church." ${ }^{36}$ Here, unlike in other places, however, the evocation of religious experience singularly fails to serve as an

44 Ibid., 211.

45 Ibid., 313. Palahniuk wrestles with this conflicted relationship between story, suffering, and experience in other places. He writes, in his essay on the "Church of Story": "Still, do we do more damage when we share our dark fantasies - when we explore them through a story or song or picture? Or when we deny them? Stories are how human beings digest their lives: by making events into something we can repeat and control, telling them until they're exhausted. Until they no longer get a laugh or gasp or teary eye. Until we can absorb, assimilate even those worst events. Our culture, it digests events by making lesser and lesser versions of the original... But the stories we're afraid to tell, to control, to craft-they never wear out, and they kill us." Palahniuk, "Church," 2.

46 Palahniuk, Haunted, 347. 
adequate referent for Cassandra's pain. Unlike the willed endurance of physical pain endured by those trapped in the theater, enacted for the base motive of personal financial gain, Cassandra's experience, which she takes into and onto her own body as she mutilates and tortures herself, becomes pain that cannot be made into something instrumental, in either the financial or medical senses of that word. The pain of the Nightmare Box, and the ways she is forced to try to assimilate that experience, offer her neither a fast track to fame and comfort nor a diagnosis of a larger and more legitimate medical condition. What it leaves her with instead is the seduction of silence and mystery enacted on her body, a bloodletting that lies beyond the realm of everyday life, beyond even the grasp of ordinary language. Walter Benjamin, interestingly, made a similar point about the horrors of WWI, an event which so informed Weber's work on the dangers and dehumanizing effects of disenchantment: "Was it not noticeable at the end of the war that men returned from the battlefield grown silentnot richer, but poorer in communicable experience?"47

The intersection of pain, suffering, science, language, and silence allows Palahniuk to make the novel's final, and perhaps most important point. The inmates and the hosts of the writer's retreat in Haunted are aware that there are these other stories, stories like Cassandra's, authentic stories of suffering that need no exaggeration, no scripting, no social legitimization; indeed, they model their own grasping acts of self-mutilation on Cassandra's more authentic example. This awareness manifests itself in other ways as well. In a particularly horrific story in a novel full of horrific stories, a story that involves a level of physical pain that is simply appalling, a dying man tells the Baroness, "When we die, these are the stories still on our lips. The stories we'll only tell strangers, someplace private in the padded cell of midnight. These important stories, we rehearse them for years in our head but never tell. These stories are ghosts, bringing people back from the dead. Just for a moment. For a visit. Every story is a ghost." ${ }^{48}$ True suffering then, is suffering that haunts, that eludes language, escapes articulation, that is not marketable, that is an important sense enchanted: "That's how a scary story works. It echoes some ancient fear. It recreates some forgotten terror. Something we'd like to think we've grown beyond. But it can still scare us to tears. It's something you'd hoped was

\footnotetext{
47 Benjamin, Walter. Illuminations: Essays and Reflections, edited by Hannah Arendt and translated by Harry Zohn, New York: Schoken Books, 1968, 84.

${ }^{4}$ Palahniuk, Haunted, 341-342.
} 
healed. Every night's scattered with them. These wandering people who can't be saved but won't die." ${ }^{\prime 9}$ For Palahniuk, not every wandering person can be saved, especially those who cannot experience the world, with all of its pain, in ways that look beyond the instrumental towards something more. Not every story is a ghost, not every story points to the world's hidden enchantments. Only good stories. Only true stories.

\section{Conclusions}

Reenchantment, then, as it is represented in the novels of Chuck Palahniuk, is radically embodied. Palahniuk's work is fundamentally concerned with the human body and the ways it can be bruised, battered, humiliated, and otherwise afflicted. He brings that flawed, damaged body to bear on the matter of reenchantment by using it to challenge conventional frameworks of value; Palahniuk offers a potent rejection of accepted standards of physical health and well-being by presenting intentional suffering as a path to authentic knowledge of both the self and the larger world. Palahniuk's fiction of protest is predicated on his assertion that those forms of pain that are the least amenable to language and commodification have the most meaning. For Palahniuk, the authentically suffering person does not understand pain as merely an indication of tissue damage, the symptom of a deeper underlying medical problem, or the potential path to fame and fortune; rather, pain must be embraced as valuable in and of itself, not merely as the means to a larger end. This is perhaps most true of pain that one invites upon oneself, an activity that Talal Asad argues is socially marginal within modern cultures, at least outside of the strictly prescribed arenas of sport and certain forms of sexuality. Ultimately, for Palahniuk it is the pain itself that matters. Understood properly, and taken on with the right intentions, pain acquires meaning and value outside of instrumental or diagnostic frameworks, meanings and values that bear distinct echoes of religious understandings of pain and the potentially salvific role of suffering. It is within this long history of the enculturation of pain, which in the West frequently intersects with Christianity, that we can best understand the collisions of body, enchantment, and religion in Palahniuk's work.

\footnotetext{
49 Ibid., 343.
} 
Such a willing - if fictional-embrace of counterproductive, destructive, transformative suffering can be seen as an example of reenchantment, the surfacing of that which cannot be left behind in modernity, that which the narrative of modernity is eager to rid itself of but which it nonetheless constantly produces, that which medical science and naturalism should have eliminated. In Palahniuk's novels, the dialectic of enchantment is revealed through the line of difference he draws between pain as a biomedical symptom and suffering as a potentially transformative experience that allows people to break free from the crushing banality of contemporary culture. On a larger canvas, Rebecca Sachs Norris argues that the instrumentalized body of biomedicine is one in which pain is experienced as profoundly disintegrating, something Palahniuk explicitly refutes in his vision of individuals made whole through physical pain; however, as Norris notes, intentional pain as experienced within many religious contexts can in fact lead to a greater sense of integration for the individual. This idea, of the integration and reintegration of the person though the deliberate pursuit of physical pain, finds a great deal of resonance with Palahniuk's views on pain and suffering, something which in turn presents a further challenge for any reader trying to understand the role and character of religion in his work. In the end, by laying bare the limits of the biomedical rationalization of pain, Palahniuk's fictional narratives offer us the reenchantment of suffering through a very hard-edged contemporary Romanticism. They show us also how subversive narratives of pain and suffering surface and resurface in the warp and weave of modern, medicalized cultures in ways that are once familiar-in the sense that they recall interpretations of pain dating back at least as far as the earliest Christian church—and fiercely contemporary. 



\section{ATTAINING TRANSCENDENCE: \\ TRANSHUMANISM, THE BODY, AND THE ABRAHAMIC RELIGIONS}

\section{Arthur Saniotis}

The last thirty years have seen the growth of biotechnologies which are offering the promise of new kinds of medical treatments for improving human performance. While many biotechnologies are in their nascent stage they reflect human concern with human decline and the loss of cognitive abilities due to trauma and ageing. The advent and growth of new biotechnologies such as genetic engineering and recombitant DNA, nanotechnology and information technology have impressed global audiences. These new technologies promise a new world which will alleviate human suffering and improve and augment human capacities. Genetic engineering, for example, has in the past ten years created recombitant animals which contain the DNA of human beings. These new technologies may pose challenging questions for the Abrahamic religions. Therefore, this chapter examines the similarities and differences between the Abrahamic religions and the growing movement of transhumanism which views new biotechnologies in a positive light.

Where are the Abrahamic religions located in relation to transhumanism? I contend that both the Abrahamic religions and transhumanism describe varying notions of the human body which are comparable. I also argue that for the Abrahamic religions and transhumanism the body is an instrument and a means of spiritual transformation. My position is informed by $\operatorname{Cox}^{1}$ who views the body as an aspect which connects the material and immaterial elements of human beings. The first section provides an overview to transhumanism and provides the backdrop for the next sections which offer a comparable analysis of the Abrahamic religions and transhumanism. Three areas of analysis are explored in relation to the body; body techniques and enhancement, the body and natural order, and becoming Godlike. While this analysis is not exhaustive it identifies points of ideological meeting between the Abrahamic religions and transhumanism in relation to the body.

${ }^{1}$ Cox, Darrel. "The Physical Body in Spiritual Formation: What God has Joined Together Let No One Put Asunder." Journal of Psychology and Christianity 21, no. 3 (2002): 281-291. 


\section{Transhumanism: An Overview}

An interesting philosophical offshoot of the new biotechnologies has been the increasing popularity of transhumanism in the Western world. Transhumanism is a school of thought which contends that future humans will be radically different due to technological forays into the human body and brain. Transhumanists view the future world as a "process of evolutionary complexification toward evermore complex structures, forms and operations". ${ }^{2}$ According to noted transhumanists such a Ray Kurzweil, Nick Bostrum, Gregory Stock and Simon Young, current human cognitive and physical capacities are limited due to evolution. The futurist artist Stellarc goes so far as to claim that the human body is obsolete and weak and needing revamping via new technologies. Various transhumanists view the body as susceptible to malfunction, fatigue, disease and ageing. In other words, humans are prisoners to their bodies due to their inherited limitations. What the transhumanist foresees is a future in which the human body shall transcend its biological constraints and be enhanced via genetic and molecular engineering, cybernetics and nanotechnology. The transhumanist movement towards body enhancement may also be viewed as the ancient human drive to alter and improve upon the human form. Many societies, both ancient and modern, have engaged in various body altering techniques in order to improve its physical performance. ${ }^{3}$ For example, Hindu, Buddhist and Sufi practitioners use meditational techniques known as pranayana and $f k r$ in order to improve heightened states of awareness. These techniques are alleged to have various benefits such as improving physical and mental well-being. Long-term benefits of meditation may include heightened awareness, improved sense of comfort and a shift in experiencing self. ${ }^{4}$ For example, according to Cahn and Polich neuroimaging studies indicate that meditation may trigger changes to the anterior cingulate cortex and dorsolateral prefrontal areas.

Some transhumanists believe that by 2030 technology will reach a singularity point which will spur a new generation of 'super' technologies. The singularity is a point whereby old paradigms are discarded for

\footnotetext{
${ }^{2}$ Young, Simon. Designer Evolution: A Transhumanist Manifesto. Amherst NY: Prometheus Books, 2006, 19.

3 Naam, Ramez. More Than Human: Embracing the Promise of Biological Enhancement. New York. Broadway Books, 2005, 9.

4 Cahn, Rael B. Polich, John. "Meditation States and Traits: EEG, ERP, and Neuroimaging Studies." Psychological Bulletin 132, no. 2 (2006): 180-211.
} 
a new reality. ${ }^{5}$ In this case, the slow pace of biological evolution will be expedited by high speed cognitive prostheses and genetically altered bodies. The predicted singularity will be a time for exponential technological enhancement, especially in the areas of computers. During the singularity super computers will achieve quantum levels of computation. Super intelligent computers will spread throughout the globe and eventually lead to human/machine interfaces.

The transhumanist project is inherently promethean, in that modern humans will eventually become posthumans-an interface between human and machine, beings who will tinker with their own evolution. Posthumans will have markedly improved cognitive and physical abilities, will live longer, perhaps be immortal, and not succumb to congenital and chronic disease. Posthumanism will be "a conglomerate of technological visions of human transformation from genetic engineering to diverse cyborg utopias". ${ }^{6}$ Kreuger asserts that a posthuman is a human descendent whose body has undergone such radical augmentation that he/she can no longer be defined as human — not a normal human anyway. ${ }^{7}$ Such people will exceed the cognitive and sensory abilities of ordinary humans. In a nutshell, the posthuman aim is towards achieving immortality using the available technologies. Posthumanism views immortality as intrinsically linked to technology. In this way, human biological evolution may eventually be supplanted by human engineered evolution. ${ }^{8}$

Posthumans may be partly or mostly biological in form, but will likely be partly or wholly postbiological-our personalities having been transferred 'into' more durable, modifiable, and faster, more powerful bodies and thinking hardware. Some of the technologies that we currently expect to play a role in allowing us to become posthuman include genetic engineering, neural-computer integration, molecular nanotechnology, and cognitive science. $^{9}$

Furthermore, the increased cognitive capacities of future humans will be able to develop new ways for dealing with the environmental crisis and creating alternative, clean energies. What transhumanism also proposes

${ }^{5}$ Tandy, Charles. "The Education of Humans and Transhumans in the Twenty-first Century." Journal of Futures Studies November 10, no. 2 (2005): 85-96.

${ }^{6}$ Krueger, Oliver. "Gnosis in Cyberspace." Journal of Evolution and Technology August 14 , no. 2 (2005): $55^{-67}, 56$.

7 Ibid.

${ }^{8}$ Ibid., 57 .

9 Graham, Elaine. “'Nietzsche Gets a Modem': Transhumanism and the Technological Sublime.” Theology March 16, no. 1 (2002): 65-80, 68. 
is the inevitability of the coherence between evolution and technology. This combination will benefit each other towards an in-built purpose or entelechy. In Kurzweil's words, "The purpose of the universe reflects the same purpose as our lives; to move toward greater intelligence and knowledge ... we will within this century be ready to infuse our solar system with our intelligence through self-replicating non-biological intelligence". ${ }^{10}$

One may ask at this point, what does posthuman existence offer? This is a pertinent question. Posthumanism offers future humans a virtual world where they may freely be able to alter their appearance without being stuck in a physical body. Posthumans may also be able to experience and enjoy various virtual utopias, savour every kind of culinary and sensual pleasure, and be in contact with other virtual beings. ${ }^{11}$ In this virtual playground new dimensions of sexuality may also be experienced without the problems of unwanted pregnancy and sexually transmitted diseases. ${ }^{12}$ Although future humans will be encouraged to shed their biological bodies this will not mean an end to physicality and sexuality.

\section{Transhumanism, the Body, and Religion: Comparable Approaches Body Techniques and Enhancement}

Both the Abrahamic religions and transhumanism do not deem the body as being a static corporeal entity, but rather as dynamic. This point needs to be explained further. In the Abrahamic religions human beings are bimorphic, composed of matter and spirit. This idea is elaborately explained in Islamic theology further. In Islam, the nafs is denotative of the human personality and is also responsible for committing sin. For example, there are five kinds of nafs in Islam, from nafs-e-ammara (lower nafs) that is interested in satisfying instinctual drives to nafs-al-mutmainnah that describes the highest level of spiritual refinement in a human being. In Sufism the journey towards the nafs-al-mutmainnah can be accomplished by controlling the lower nafs via a series of bodily techniques such as fasting, sequestering, meditation, prayer, and pious works. In this way, the lower nafs is rigorously checked (ridayat an-nafs). Once ridayat an-nafs is attained can the Sufi enter into a state of awareness in which the nafs is 'dissolved' or 'annihilated' within the Divine (fana); a state analogous with

\footnotetext{
${ }^{10}$ Kurzweil, Raymond. The Singularity Is Near. New York: Viking, 2005, 372.

"Kruger, "Gnosis in Cyberspace," 52.

${ }^{12}$ Moravic, Hans \& F. Pohl. "Souls in Silicon." Omni 11 (1993): 66-76, 74.
} 
the Buddhist notion of nirvana or the Hindu notion of moksha. Human nature is described as yetzer meaning 'impulse'. Yetzer is further categorised as yetzer ra and yetzer tov; in the former the human being is governed by selfish desires that can lead a human to commit evil. In the latter, the person's moral conscience informs his/her thought and actions.

An interesting aspect of Judaism is that the soul's existence is not dependent on the body since it existed in eternity with God. In this way, the soul is theocentric, in other words, the soul's final destination is towards union with God. Human life is in a state of 'ab initio', in a state of imperfection and striving towards perfection 'shlemut'. "Because man is other than his physical surroundings, the real is found in the perfection of the soul... It is this process of perfection that man continues to rely on the supernatural realm for his identity". ${ }^{13}$ What is important here is that the body is constantly being monitored through various disciplines. Sufism has developed over many centuries various ascetic based practices for controlling bodily urges and desires through fasting, intensive prayer and meditation, sequestering and chanting. Such practices are also found in many Christian monastic orders. In Islamic and Christian forms of asceticism the body is deemed a vehicle for spiritual transformation. It is central to spiritual awakening. This point is made clear by Cox when he states that the whole person is important in spiritual transformation in Christianity. Cox opines that traditional Christian notions of the body as being less significant was influenced by Greek dualism which deemed the body as being inferior to spirit. ${ }^{14}$ Willard's holistic model of the body is relevant here. ${ }^{15}$ For Willard, the human being is an inter-connected matrix of mind, emotions and physiology which assists various functions such as sensing danger and responding to one's environment. In addition, Cox tells us that the human body is not inherently evil but should be considered as a gatekeeper that needs to be consistent with God's purposes. ${ }^{16}$

Cox's reformulation of the body in Christianity is similar to Islam. The body in Islam is meticulously controlled by an ongoing repertoire of body techniques that are aimed towards a "complete and absolute cathecting

${ }^{13}$ Elior, Rachel. Contemporary Jewish Religious Thought. New York: Collier Macmillian Publishers, 1972, 888.

${ }^{14}$ Cox, The Physical Body.

${ }_{15}$ Willard, D. Renovation of the Heart: Putting on the Character of Christ. Colorado Springs, CO: Navpress, 2002.

${ }_{16}$ Cox, The Physical Body, 288. 
or investment of the body". ${ }^{17}$ Most Muslims are brought up with a total mistrust for dirt and uncleanness, especially where it compromises their immediate surroundings. ${ }^{18}$ This is especially the case where dirt invades the bodily domain, promoting a rigorous response by the individual to remove it. Several techniques may be employed to free oneself from the polluting aspects of dirt, including religious ablution (wuzu), reciting of religious formulas, wearing of clean clothes, keeping one's surroundings clean, keeping the orifices clean, and bathing after coitus. As Bouhdiba puts it, "Eating, drinking, urinating, farting, defecating, having sexual intercourse, vomiting, bleeding;" all compromise in varying degrees one's control over bodily boundaries. ${ }^{19}$ What is important is that the body must be restored to its previous state of purity, since it is only through this state that the believer can continue their "quest for spirituality". ${ }^{20}$ The point to emerge here is that bodily purification, or its lack, is coextensive with the pan Islamic view of keeping the bodily orifices in check. The famous Islamic saying, "Cleanliness is part of faith. Dirt is the work of the devil". ${ }^{21}$

Similar to the Abrahamic religions the body is informed by a series of special techniques in order to transform it to superior entity. These techniques include gene therapy, nanotechnology, brain-machine interfaces, cosmetic neurology, or a combination of these. Of these, cosmetic neurology is widely engaged in western countries. Cosmetic neurology relates to the non-therapeautic use of pharmacological substances by healthy adults in order to enhance cognitive abilities. For example, research has shown that $18 \%$ of American college students use some form of pharmacological study aid in the form of prescription stimulants (Dextro-Amphetamine and Methylphenidate). ${ }^{22}$ Currently, various kinds of pharmacological therapies are being used to improve neural plasticity and motor learning. ${ }^{23}$ In the future novel kinds of drugs will be used to improve cognitive

${ }^{17}$ Bouhdiba, A. Sexuality in Islam (A. Sheridan, trans.). London: Routledge and Kegan Paul, 1985,56 .

${ }^{18}$ Ibid.

${ }^{19}$ Ibid., $55-56$.

${ }^{20}$ Ibid., 55 .

${ }^{21}$ Ibid.

${ }^{22}$ Farah, Martha. Iles, Judy. Cook-Degan, Robert. Gardner, Howard. Randel, Eric. King, Patricia. Parens, Eric. Sahakian, Barbara. \& Paul Root Wolpe. "Neurocognitive Enhancement: What Can We Do and What Should We Do?" Nature, May 5 (2004), 421-425, 421; Babcock, Q. \& T. Byrne. "Student Perceptions of Methylphenidate Abuse at a Public Liberal Arts College." Journal of American College Health, 49 (2002), 143-145.

${ }^{23}$ Saniotis, Arthur. "Present and Future Developments in Cognitive Enhancement Technologies." Journal of Futures Studies August 14, no. 1 (2009): 27-38, 33. 
performance. ${ }^{24}$ Such drugs may include Atomoxetic to increase arousal levels and Modafinil for enhanced alertness. Modafinil, for instance, has been identified as improving reaction time in memory tests and working memory in aviators. ${ }^{25}$

The use of pharmacological substances for cognitive enhancements is not dissimilar to the employment of cannabis by Indian sufis in order to enhance altered states of consciousness. For transhumanists and sufis, the mind is neuro-plastic and is capable of entering into heightened states of awareness. Such heightened states of awareness may lead to more insightful understandings of the self and the lifeworld. Additionally, the use of pharmacological substances is an extension of meditative and contemplative techniques found in Abrahamic religions which foster heightened awareness. In the future, pharmacological substances may combine nanotechnology in order to improve their precision and efficacy. New kinds of religious and spiritual experiences may be triggered by such drugs, especially when combined with other bio-technologies such as brain-machine interfaces.

What is important is that such technologies in the future may be used by both transhumanists and followers of Abrahamic religions for similar reasons, that is, to delve deeper into human consciousness. On this note, Greenfield argues that in the future human brains will be connected to computers that will provide individuals with a kaleidoscope of virtual worlds to engage with. ${ }^{26}$ The engagement with virtual worlds may actually deepen religious experience by allowing individuals to engage with states of consciousness which are currently accessible by manipulating consciousness via meditational techniques and pharmacological substances. The point is that future enhancement body techniques will not necessarily promote a divide between transhumanism and Abrahamic religions but rather create new ways for engaging with non-ordinary states of consciousness. Possibly, here, transhumanists, via the use of such

\footnotetext{
${ }^{24}$ Connemann, B.J., Mumenthaler, M.S., Yesavage, J.A., Taylor, J.L., Friedman, R., O'Hara, J., Sheikh, J., Tinklenberg, J., \& P.J. Whitehouse. "Donepezil and Flight Simulator Performance: Effects on Retention of Complex Skills," Neurology, September 9, 2003, 61, no. 5: 721-731.

${ }_{25}$ Bostrom, N., \&A.Sandberg. Cognitive Enhancement:Methods, Ethics, RegulatoryChallenges. The Future of Humanity Institute, Oxford University, 2006, 8. Caldwell, J.A., Jr., Caldwell, J.L., Smythe, N.K., \& K.K. Hall. 200o. "A Double-blind, Placebo Controlled Investigation of the Efficacy of Modafinil for Sustaining the Alertness and Performance of Aviators: A Helicopter Simulator Study." Psychopharmacology (Berl), 150, no. 3 (2002), 272-282.

${ }^{26}$ Greenfield, Susan. Tomorrow's People: How 21st Century Technology is Changing the Way We Think and Feel. London: Penguin Books, 2003.
} 
technologies, may appreciate the intense religious like experiences consistent with followers of the Abrahamic religions.

\section{Body and Natural Order}

The Abrahamic religions view the body as part of the natural order. Natural order is emphasised in the Abrahamic religions in order to conceive the universe in a particular way. In Islam, the universe is created by the act of Divine mercy (rahma), and is characterised by al-fitra (natural order). The universe is believed to embody al-fitra such as in the kaleidoscope array of meta-patterns inherent in nature. Medieval Christian and Muslim scholars often portrayed the body in naturalistic ways such as via the model of microcosm-macrocosm. The human being was considered as a miniature of the universe, embodying similar patterns inherent throughout the cosmos. Islamic thinkers made connections between the body and the cosmos. For example, the twelve bodily orifices corresponded with the twelve zodiacal signs, while the veins contained in the body were believed to equate to the number of solar days. ${ }^{27}$ This idea of naturalness in the Abrahamic religions is also considered to manifest in individual and collective behaviours such as circumcision, respect to elders and correct parenting.

Transhumanism also adheres to naturalistic notions of the body via Darwinian evolution. In this schema the human body is a product of millions of years of natural selection and genetic variation which has provided the extant body with its unique physical and mental characteristics. Recent discoveries in molecular biology have created a Darwinian version of microcosm-macrocosm. In this model, humans beings (Homo sapiens) are genetically related to all life on earth, to the point that they share $98 \%$ of mitochondrial DNA with chimpanzees (Pan troglodytes). Even from a point of view of human brain evolution, the noted neuroscientist Paul Maclean pointed to the human brain's tri-partite structure, reflecting reptilian and paleo-mammalian ancestry. ${ }^{28}$ In other words, the bodies and brains of extant humans are evolutionary repositories going back to hundreds of millions of years. At a cosmic scale, Carl Sagan and other

\footnotetext{
${ }^{27}$ Ardalan, N. Bakhtiar, L. The Sense of Unity: The Sufi Tradition in Persian Architecture. Chicago: University of Chicago Press, 1971.

${ }_{28}$ MacLean, Paul D. The Triune Brain in Evolution: Role in Paleocerebral Functions. New York: Plenum Press, 1990.
} 
astrophysicists have elaborated this naturalistic connection by pointing out that every elemental atom in the human body was once contained in stars which became unleashed through supernovae. As Sagan stated, humans are composed of "star stuff".

Transhumanists use Darwinian evolution as a means of explaining the present limitations of the human body. However, the kinds of physical and cognitive enhancements which transhumanism proposes for the human body work within the ambit of 'natural' evolution. In transhumanist philosophy human development and use of technology altered the course of human evolution. Technology became intrinsic to human evolution to the point that it worked in tandem with natural selection.

The naturalistic approaches of the body of the Abrahamic religions and transhumanist philosophy should be viewed as models for understanding the connectedness between the human and non-human worlds. In Christian Creation Theology this means that human beings find their true identity by interacting with non-human life forms. ${ }^{29}$ Transhumanist philosophy takes this potential interaction between humans and non-humans one step further is via - the combination of human and non-human DNA. This is an area of transhumanist interest which has interesting religious implications since recombitant DNA technology is already being used via 'pharm animals' (genetically modified animals containing human DNA). The proposition that transgenics may alter human beings' cognitive and sensory capacities has been noted by Julian Savulescu and Paul Ehrlich. ${ }^{30}$ For Savulescu, recombitant DNA between humans and nonhuman animals is a way of improving human cognition and sensory perception. In transhumanist thought, such biological enhancements may have wider social and health benefits. For example, future humanity may be able to reduce the rate of telomere (a region where exists repetitive DNA sequencing at the end of a chromosome) degradation via recombining human genetic material with long lived animals such as the Galapagos tortoise, or improve the human neuronal memory function by transferring the gene responsible for long term memory in elephants. ${ }^{31}$ Moreover, the novel splicing of the owl or rabbit gene responsible for enhanced night

\footnotetext{
${ }^{29}$ O'Murchu, Diarmuid. Quantum Theology: Spiritual Implications of the New Physics. New York: The Crossroad Publishing Company, 2004, 11.

$3^{0}$ Ehrlich, Paul R. Human Natures: Genes, Cultures, and the Human Project. Washington D.C. \& Covelo, California: Island Press, 2000.

${ }^{31}$ Savulescu, Julian. "Human-animal Transgenesis and Chimeras Might be an Expression of Our Humanity." The American Journal of Bioethics Summer 3, no. 3 (2003): 22-25, 111.
} 
vision in human beings may curtail night time road accidents and assist rescue teams. ${ }^{32}$

The transgenics approach is cognate with the Abrahamic religions as both examine how humans can become co-creators in their lifeworlds. Creation and Islamic theologies extol the order of the universe which enables the Divine to participate in the cosmos. Similarly, transhumanist philosophy views humanity as being able to re-evolve itself within the universe, as an active participant. Both Abrahamic and transhumanist approaches, then, privilege human creativity and its capacity to become creative participants in the cosmos.

\section{Becoming Godlike}

It was the ancient Greeks who aspired towards a vision of the body's physical perfection. Greek sciences and arts were testimonies of the perfection ideal toward which they strove. The importance of perfection is also an integral element of Christianity. However, Christian perfection focuses on cleansing the soul so that its nature mirrors the nature of God. In mystical Islam (Sufism) the heart is the seat of the Divine. Sufis use the metaphor of 'polishing the mirror of one's heart' in order for humans to reflect the Divine nature. In other words, it is condoned in Abrahamic religions for humans to become godlike in relation to intellectual and moral development. In Christian terminology humans are viewed as God's children "in exactly the same way that we are the parents of our children". ${ }^{33}$ If we are God's children, then, might we not strive to "become like our Father, just as we expect that our children will become like us in time" ${ }^{34}$ Literally speaking, "this idea implies that upon maturity we too should be gods" ${ }^{35}$ This line of inquiry is also found in transhumanist philosophy since it offers possibilities for "improving our intellectual and moral natures". ${ }^{6}$ For Campbell and Walker this kind of argument provides a tenable "transhumanist-religious hybrid": from transhumanism it draws from the idea of self improvement, and from religion this hybrid draws from the idea

\footnotetext{
$3^{2}$ Ibid.

33 Campbell, Heidi, Walker, Max. 2005. "Religion and Transhumanism: Introducing a Conversation." Journal of Evolution and Technology April 14, no. 2 (2005): 1-11, 5 .

34 Ibid.

35 Ibid.

${ }_{36}$ Ibid.
} 
that "part of our maturation process" is to become like our Heavenly Father. ${ }^{37}$

The "theological accommodation of this hybrid" has surprisingly found sympathy within the writings of the late John Paul II. In an article on the pope's writings the eastern orthodox theologian David Hart writes,

there is, as it happens, nothing inherently wicked in the desire to become a god, at least not from the perspective of Christian tradition; and I would even say that if there is one element of the transhumanist creed that is not wholly contemptible-one isolated moment of innocence, however fleeting and imperfect-it is the earnestness with which it gives expression to this perfectly natural longing. ${ }^{38}$

Hart further describes this longing as follows:

Theologically speaking, the proper destiny of human beings is to be "glorified"-or "divinized" in Christ by the power of the holy Spirit, to become "partakers of the one divine nature (II Peter 1:4), to be called gods (Psalm 82:6: John 10:34-36). This is the venerable doctrine of "theosis" or "deification" the teaching that - to employ a lapidary formula of great antiquity- "God became man that man might become god": that is to say, in assuming human nature in the incarnation, Christ opened the path to union with the divine nature for all persons. ${ }^{39}$

Hart's connection between tranhumanism and the concept of theosis is interesting in that it identifies that the goal of human destiny is to become godlike. Hart's thesis also entertains the potential for transhumanism and Abrahamic religions to share a common goal, albeit, through different methods. While transhumanism and the Abrahamic religions "share a common symbolic of transcendence, fear of finitude, craving for immortality and god-like pretensions", ${ }^{40}$ the alleged gulf between them may be more superficial than certain.

\section{Conclusion}

This analysis has examined comparable elements between Abrahamic religions and transhumanism in relation to the body. The first section

\footnotetext{
37 Ibid.

${ }^{38}$ Hart, David, B. “The Anti-theology of the Body." The New Atlantis Summer 9 (2005): $65-73$.

39 Ibid.

40 Graham, “'Nietzsche Gets a Modem,'” 73.
} 
provided an overview of transhumanist philosophy. Transhumanism is a school of thought which endeavours to engineer the human body beyond its present capabilities. The goal of transhumanism is for future humanity to become post-human-humans with superior physical and mental capabilities who have mastered techniques in achieving immortality. Both Abrahamic religions and transhumanism privilege the body with attaining transcendent dimensions.

My examination further explored three areas of ideological meeting between the Abrahamic religions and transhumanism; body techniques and enhancement, the body and natural order, and becoming Godlike. Both the Abrahamic religions and transhumanism offer an array of body techniques for enhancing physical and mental abilities. In the Abrahamic religions such techniques include meditational practices, fasting, sequestering and various kinds of sensory deprivation which Winkelman claims derive from prehistoric shamanic mind practices. Such practices may trigger a transformation of consciousness, ${ }^{41}$ and for reintegrating the human psyche. While these techniques are fundamentally religious in nature, their prolonged engagement may lead to various physical and mental benefits. For transhumanism various new bio-technologies may improve human cognitive and physical abilities. Technologies such as nanotechnology, gene therapy, cosmetic neurology, and brain-machine interfaces are deemed as enabling future humans to become post-humans. Possibly, the use of such technologies may lead to attaining transcendent states of consciousness which are consistent with religious experiences. What transhumanists pose is that such an evolution is not only necessary but will in effect enable them to experience "new modes of thought and experience, thus adding to the palette of possible religious feelings". ${ }^{22}$

In relation to the body and natural order both the Abrahamic religions and transhumanist philosophy offer naturalistic approaches to the body. For the former, naturalism is conceived of as microcosm/macrocosm, where the body is considered as a miniature of the universe. The body conveys universal dimensions of symmetry and harmony. For transhumanism, the body is a product of natural selection and variation, a system of evolutionary tradeoffs. While the body is impressive it has limitations which future technologies may improve.

\footnotetext{
${ }^{41}$ Winkelman, Michael. 2002. "Shamanism as Neurotheology and Evolutionary Psychology." American Behavioral Scientist 45 (12): 1873-1885.

${ }^{42}$ Jordan, Gregory. "Apologia for Transhumanist Religion." Journal of Evolution and Technology February 15, no. 1 (2005): 55-72, 58.
} 
Finally, Abrahamic religions and transhumanist philosophy share a view of human beings becoming godlike. I drew attention to Hart's notion of theosis which identifies an ideological meeting between the Abrahamic religions and transhumanist philosophy. Thus, followers of the Abrahamic religions and transhumanists may be the inheritors of a new consciousness which will be able to draw forth the wonder and mystery of the universe. ${ }^{43}$

The values underlying the Abrahamic religions are fundamentally directed to understanding Divine manifestation in the universe. In Islam, for example, God's signs (ayat) are manifest everywhere in the cosmos and offer ways for humans to understand Divine creativity and its limitless possibilities. Such signs are intended to change the consciousness of humans so that they become more attentive to the Divine. Similarly, transhumanist philosophy entertains future post humans as being more considerate to the environment and developing spiritual values.

${ }^{43}$ Ibid. 

SECTION THREE

(CROSS) CULTURAL APPROPRIATIONS OF THE BODY 



\title{
MAGNETISM AND MICROWAVES: RELIGION AS RADIATION
}

\author{
Deana L. Weibel
}

My fieldwork as a cultural anthropologist in the shrine town and pilgrimage center of Rocamadour, France allowed me to talk to both pilgrims and local residents about what makes Rocamadour special. Many people's views fall into the traditional Catholic explanation of pilgrimage, namely that God or the Virgin Mary has selected certain locations as places where people should come to worship, sometimes marking these places with miraculous events. Quite a few, however, see certain geographic locations, Rocamadour among them, as places where unusual energies are present, energies that can affect and change the human body.

These energies, described by one informant as 'geobiological,' are described in different manners, but in all cases are characterized as real, measurable (at least in some ways), and bioactive. Much in the way that a lodestone can magnetize pieces of iron, sites where energies are present are seen as being able to change humans in a fundamental way, transforming the physical (and spiritual) bodies of the people nearby. This view is radically different from the traditional view of Catholic pilgrimage, in that it offers a scientific (or quasi-scientific) explanation both for what makes sacred sites sacred and why people appear to have anomalous experiences at these sites.

This chapter will examine the notion of a geobiological understanding of sacred sites, Rocamadour in particular, from the perspectives of pilgrims to and residents of these places. I will look into how this alternative understanding marks a transformation in how sacred sites and spiritual experiences at these sites are interpreted, how the idea of energy is used as a mental model for conceptualizing religious experiences in specific places, and how this approach is used by 'religious creatives' (a term referring to those practicing deliberate syncretism). I will also consider the evolution of pilgrims' science-based notions about essential relationships between biological bodies and geographic locations, as demonstrated by esoteric literature and French folk science, and will examine how and why their reinterpretations of pilgrimage centers co-exist with the persistent idea that these places are spiritually powerful, bringing in some current cognitive and neurobiological arguments about the relationship between religious belief, ritual behavior, and the human mind. 
Through this examination, I will demonstrate that religious creatives' use of scientific (or scientific-sounding) concepts and terminology serves a legitimating function for these pilgrims, permitting explanations for a site's 'sacred' status that they see as both surpassing orthodox explanations (in that understandings based in the natural are superior to those found in the supernatural), and as universalizing and equalizing sacred sites around the world, so that these sites' significance is expanded beyond the religious traditions usually associated with them. I will argue that these explanations, while not provable by current scientific research (which nevertheless may shed light on the form they take), reflect and modify scientific beliefs of various eras. These modifications, which are often seen as improving a limited, exclusionist, mainstream form of science, assist religious creatives in the project of reconciling religion and science, which they generally see as two equivalent windows for viewing reality. Finally, I will contend that some sacred sites possess topographical features that, according to contemporary neuroscience and evolutionary biology, may be particularly attractive to pilgrims and/or stimulate eerie or numinous feelings, strengthening pilgrims' convictions that these places are somehow exceptional.

\section{Rocamadour}

When I came to Rocamadour in 1997 as a graduate student, I expected to study both the pilgrims to the shrine and the locals who inhabited what was considered a sacred landscape. Rocamadour is a Roman Catholic shrine, part of what is arguably a collection of French shrines dedicated to the veneration of the Virgin Mary, including Lourdes, La Salette, Le-Puy-en-Velay and many others. I was aware that France was a rather secular country overall and soon learned that many residents of Rocamadour were self-described atheists. I also learned that the golden age of Rocamadour's pilgrimage was during the twelfth and thirteenth centuries. By the time I began conducting research there in the late twentieth century, Rocamadour's identity had dramatically shifted and the town was now a popular tourist attraction whose identity as a pilgrimage center was secondary at best.

Among the reasons for this change is Rocamadour's unusual, striking physical appearance. Rising above the deep Alzou Canyon, the town's castle, churches and other architectural features are built up against an impressive 130 meter cliff, with many of the buildings using the cliff face 


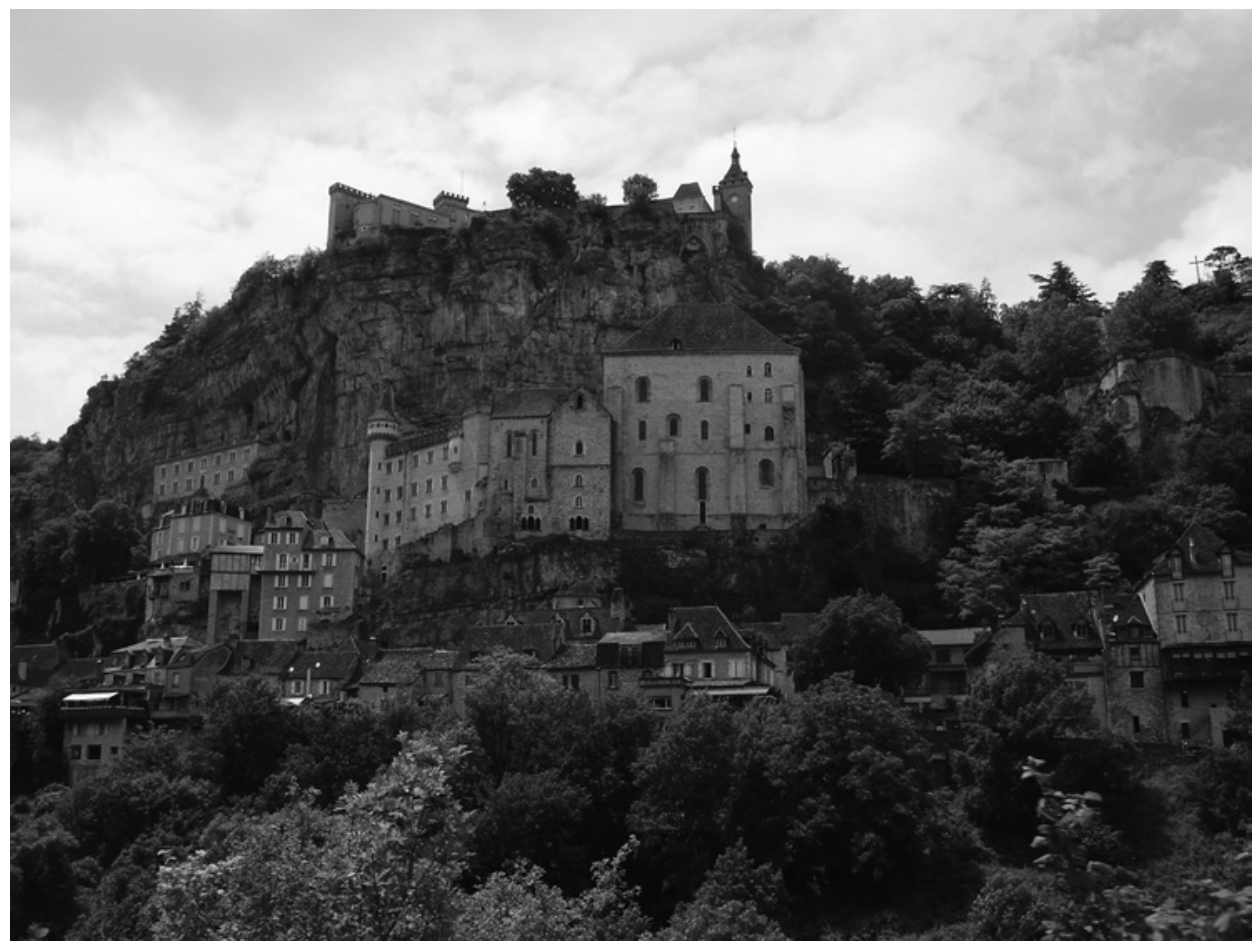

Figure 1. View of Rocamadour from across the Alzou Canyon.

as their fourth wall. The effect is spectacular from an architectural perspective, but also as a testament of faith and as a feat of construction that somehow manages to incorporate these buildings into the natural landscape. The beauty of Rocamadour has almost certainly attracted more people than its pilgrimage, and over the twentieth century, theme parks and attractions of various kinds appeared in the vicinity, taking advantage of and contributing to the flow of tourists, up to 1.5 million annually.

Despite this, pilgrimage endures. Rocamadour's pilgrimage was first mentioned in 1105 in a document by Pope Pascal II. It is an ancient Marian shrine, possessed of a Black Madonna statue in the twelfth century 'throne of wisdom' style, and its origin story cites a hermit, St. Amadour, who lived in the shelter of the cliff and created the original gravity-defying buildings to prove his devotion to the Virgin. A Book of Miracles, written around 1172 , demonstrates that the site was also associated with numerous supernatural events, including healings and acts of divine retribution against the unrepentant. In some ways it is a classic Catholic shrine, associated 


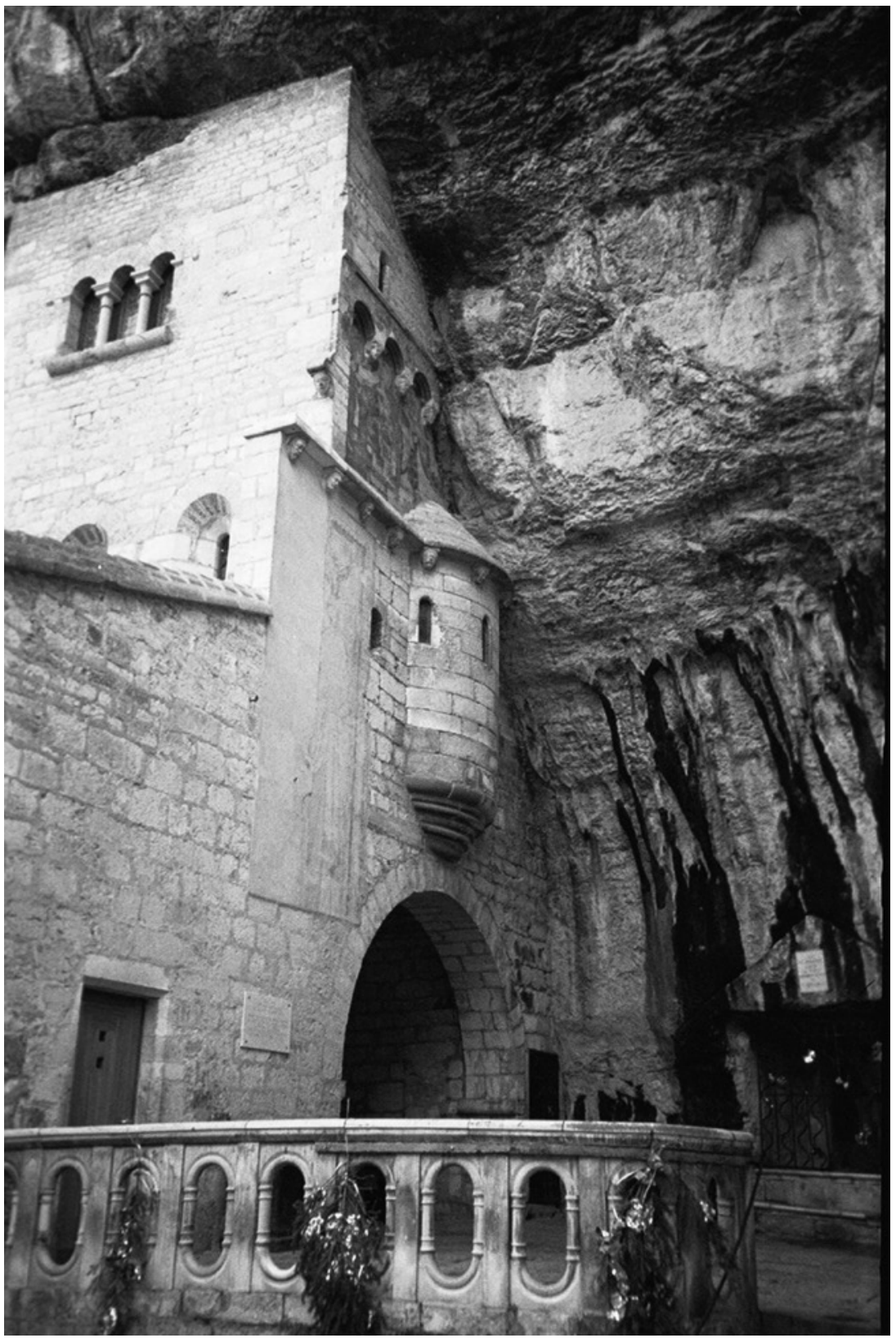

Figure 2. St. Michel Chapel at Rocamadour, showing the architectural placement of the buildings against the cliff wall. 
with devotion and divine intervention. Although the tourists currently far outnumber pilgrims, Catholic pilgrims still visit the shrine and process during days dedicated to the Virgin Mary, like the Assumption on August

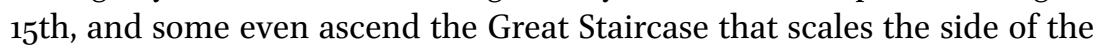
cliff in the traditional fashion, on their knees.

\section{Energy at a Sacred Site}

I spent the early days of my research focused on Catholic understandings of the shrine and how tourism had impacted what was once such a sacred space. One May afternoon I saw a man and a woman performing the traditional ritual of climbing the stairs on their knees and was able to interview them after they had completed their act of reverence. I was very surprised when the woman explained the reason for their visit. There are energy points on the earth, just like energy points on the body, she explained, and the Virgin Mary tries to show humans where these places are. These points, she said, radiate energy and humans radiate energy (through prayer) and this is how the earth breathes. She continued that when people go to pilgrimage sites like Rocamadour they gain energy. She claimed that pilgrims give back energy by praying, but that tourists do not, so it's possible for a site to run out of energy. Therefore, she concluded, pilgrimage is going to an energy point and giving and receiving the earth's energy.

These pilgrims belonged to an esoteric French Christian association, Invitation à la Vie (Invitation to Life) but told me that they conducted similar visits to non-Christian sites like Teotihuacan, a pre-Christian Mexican site known for its pyramids, and the Ganges River in India, which is sacred to most Hindus. This tendency to consider sacred spaces from a variety of ancient and modern traditions as appropriate pilgrimage destinations turned out to be fairly common among not just esoteric Christians, but Wiccan, Neo-Pagan and 'New Age' pilgrims as well. In earlier writings about this style of religiosity, I coined the term 'religious creative' (analogous to 'religious conservative') to refer to believers from any background who blend aspects of diverse religions together in order to create an idiosyncratic mix that speaks to them in a compelling way. ${ }^{1}$ A typical religious

${ }^{1}$ Weibel, Deana L. "Of Consciousness Changes and Fortified Faith: Creativist and Catholic Pilgrimage at French Catholic Shrines," in Pilgrimage and Healing, ed. Jill Dubisch and Michael Winkelman. Tucson: University of Arizona Press, 2005, 113. 
creative might see the earth as a Goddess, read Hindu scripture and Sufi poetry, and be inspired by the Jewish mythological figure of Lilith, but find Catholic pilgrimage centers to be the most compelling. What seems to be a common element among creatives is the notion that all religions (at least in their pure, original forms) are equally true and equally good at explaining and expressing divinity.

Creativist pilgrims to Rocamadour were especially likely to describe the shrine town in terms of energy. I interviewed people who saw the site in terms of impersonal energy, like microwaves, that naturally abounded along Rocamadour's cliff but came in its strongest form from the statue of the Black Madonna, and others who felt that the Goddess (described by a group of Wiccan pilgrims as 'the energy we call the Goddess') could take the form of an energy that entered and transformed the human body upon request. Another pilgrim spoke of how "atomic energy" could be different at certain geographical locations causing them to be "very positive" locations to visit.

When I asked the traditional Catholic clergy at Rocamadour about these types of pilgrims, I found most had knowledge of them but had elected not to include them when I had asked about pilgrims to the shrine. They seemed to see these energy-oriented pilgrims as nuisances at best. Sister Bernard, one of the nuns that lived in a house where bedrooms were retained for Catholic pilgrims, admitted that she had seen a man enter Rocamadour's small basilica (which, along with the Chapel of the Black Madonna, is one of the seven churches at Rocamadour) holding a V-shaped piece of iron with the ends jutting outward, incomprehensibly (to her) walking back and forth. She also mentioned that a 'geobiologist' had once told her that the site was thick with telluric forces. ${ }^{2}$

Despite the characterization by many of this belief in at Rocamadour as stemming from a competing religious view, quite a few of the locals understood the site's connection to unusual forces as completely secular. Leona, a woman in her eighties whose family had run souvenir stores in the town since the early 1800 , told me that telluric forces were not super-

\footnotetext{
2 'Telluric' comes from tellus, a Latin term for earth, and the term 'telluric energy' refers most basically to any energy that comes from the earth or the ground. The term is sometimes used by those involved in obtaining oil or natural gas to refer to energy sources that come from beneath the ground, but Neo-Pagan and New Age informants tend to define it simply as energy within the earth that can be contrasted with cosmic energy from space. My French informants who defined it in secular terms tended to associate it with the folk technology of la sourcellerie, or dowsing.
} 
natural in any way, but were a normal type of geological current, similar to electrical current. She explained that a major current of energy flows from Belgium to Rocamadour and that it accumulates in cavities below the street at the bottom of the cliff. She and several others at Rocamadour, most of whom self-identified as atheists, believed that telluric energy was a real force, totally natural, and only appeared to be supernatural because people experienced unusual feelings when they sensed it without realizing what they were sensing. Marielle, who owned a shop along Rocamadour's main tourist thoroughfare, considered Rocamadour's religious significance to be completely fictional and was cynical about religion in any form. She did, however, believe in telluric energies that filled the cavities below the street. These energies were essentially negative, she stated, causing the merchants along the street to fight with one another and driving away business.

These are accounts of unusual energies that, depending on the attitude of the informant, were described either as spiritually significant in some way, or as totally impersonal forces that nevertheless could affect people (and animals) physically and unconsciously. The type of energy mentioned the most were the so-called 'telluric' forces. Whatever the type of energy associated with Rocamadour, explanations by pilgrims or locals that linked Rocamadour with some kind of unusual force or power made it distinct from locations that do not possess similar energies. These stories identified Rocamadour as a special location, one where people may have special experiences or notice special sensations. Rocamadour's prior renown basically characterized the site as a place where a pious hermit came to honor the Virgin Mary, where Mary gave her blessing, where pilgrims as noble as St. Louis processed, and where divine miracles occurred. This would seem to be distinction enough. Tales of energy, which seem to arise in the late nineteenth or early twentieth century, add another layer of significance to Rocamadour, one that, depending on the teller, may contradict or reinforce more traditional characterizations of the site.

\section{Energy and Geography}

What is 'energy' from a scientific perspective? Merriam-Webster's Online Dictionary gives multiple definitions, ranging from "a dynamic quality" to "usable power" and "the resources for producing such power." The most technical definition given reads, "a fundamental entity of nature that is transferred between parts of a system in the production of physical change 
within the system and usually regarded as the capacity for doing work." This means, then, that if locations have energy they can effect change of some kind, at least potentially. Do such types of energy exist in geographic locations?

Much of the energy people are exposed to in their daily lives comes from the sun, the sky, the earth, and the air. Energy from these sources does affect the human body, but generally in positive ways or in ways that are usually only mildly or temporarily harmful (someone experiencing a sunburn or melanoma might disagree). Artificially produced radiation from cell phones, electric blankets and other devices is being studied for possible harmful effects, such as increased incidence of miscarriage and cancer, but many feel that their effects, if any, are slight. Other types of radiation, like sunlight, are clearly essential for life, allowing plants to photosynthesize and human skin to produce vitamin D.

Ultraviolet rays can encourage cells in the human body to grow malignant, as can contact with radon gases that escape from the earth. People are generally cautioned by scientists to avoid certain kinds of harmful radiation. Those who work in potentially highly radioactive environments, like the astronauts whose long-term exposure to space puts them at greater risk, must take special precautions to protect themselves. According to Valerie Olson, astronauts are officially categorized as 'radiation workers' and must wear dosimeters while in space to track their 'exposure years.' The changes enacted by these dangerous energies include chromosomal damage and cell proliferation. "Radiation Report," published in Aviation Week and Space Technology, discusses what would have happened if astronauts on the moon had been exposed to the radiation of a solar flare while in their very vulnerable position, noting that "the estimated radiation could have resulted in serious skin damage, including blistering and peeling, as well as nausea and vomiting." ${ }^{4}$ Most people are aware, of course, that radiation poisoning can ultimately kill those who survive the initial strike of a nuclear attack.

Another type of 'energy' referenced by religious creatives that influences life in a scientifically measurable way is magnetism. Magnetism is a natural force of the earth, with the magnetic pull of the North Pole the most well known example. Geophysicists are able to locate magnetic and

\footnotetext{
${ }^{3}$ Olson, Valerie. "American Extreme: An Ethnography of Astronautical Visions and Ecologies." PhD diss., Rice University, 2010.

${ }^{4}$ Morring, Frank Jr. (Ed.), “Radiation Report," Aviation Week \& Space Technology 165:17 (2006): $5^{2}$.
} 
electric (telluric) ${ }^{5}$ fields beneath the surface of the earth and analyze them in terms of electrical conductivity or resistivity. In some cases, these fields vary based upon differences in rock formations and certain subsurface structures. ${ }^{6}$ Magnetic fields do seem to influence biology. Many animals appear to migrate using magnetic fields as a guide, and research by Peter Hore, a University of Oxford physical chemist, has suggested that weak magnetic fields affect the production of a particular molecule type in a specific photosynthetic Rhodobacter bacterium, allowing these bacteria to grow better than they normally would in weak magnetic fields. ${ }^{7}$

The ability of magnetic fields to effect change on the human body has been studied as well. Research into the role of right temporoparietal junction (RTPJ) activity on moral judgments has shown that when subjects have high activity, they judge an activity as moral or immoral based on both the outcome and on the intentions of the actors. Low RTPJ activity in subjects caused them to focus more on outcome than on actors' intentions when assigning blame. RTPJ activity can be modified, however, using magnetic fields. Liane Young and Rebecca Saxe write that "( $t$ )emporarily disrupting RTPJ activity using transcranial magnetic stimulation also resulted in more outcome based moral judgments." ${ }^{8}$ Exposure to magnetic fields, apparently, in certain circumstances, can bring about physical changes that change the way people evaluate situations.

Established scientific sources would confirm then, that certain geographic (and cosmic) locations produce radiation, and that some sites also feature strong or weak magnetic fields. These scientists would also confirm that radiation and magnetism can affect biological and mental processes. There seems, however, to be little link between sites studied for their unusual radiation or magnetic properties by geophysicists and those identified by creativist pilgrims as having unusual energies. Instead, it appears that proven scientific data is a source of ideas for creativist pilgrims, who then go on to reinterpret these ideas in ways based on

${ }_{5}$ The geophysical use of the term 'telluric' also refers to energy in the earth, but without reference to the purported metaphysical characteristics emphasized by creativist pilgrims.

${ }^{6}$ Whaler, K.A. "Magnetotelluric Fieldwork Adventures in Africa." Astronomy \& Geophysics: The Journal of the Royal Astronomical Society 47:2 (2006): 2.28.

7 Peplow, Mark. "Magnetic Field Benefits Bacteria," Nature News, November 26, 2004, accessed May 10, 2010, http://www.nature.com/news/2004/041122/full/newso41122-13 .html.

8 Young, Liane and Rebecca Saxe, "Moral Universals and Individual Differences," Emotion Review 3:3 (2011): 324. 
their own subjective experiences at particular sites. In some cases concepts found initially in scientific journals make their way into the popular consciousness (where they can then be modified) through metaphysical literature.

\section{"Energies" and Geography_Ley Lines and Radiesthesia}

Anthropologist Jeffery MacDonald and historian Ronald Hutton both associate the contemporary view held by many Neo-Pagans and New Agers that sacred sites are places of special energy with the work of Englishman Alfred Watkins. Watkins, an antiquarian interested in both pre-Christian and Christian sacred sites in Great Britain, came to the conclusion in the early 1920s that many of these sites seemed to "fall into alignments of straight lines over long distances." ${ }^{9}$ He called these straight lines 'ley lines.' While MacDonald states that Watkins never determined any clear explanation for why ley lines would exist, Hutton argues that Watkins believed they were religious in origin and that "those who surveyed them had been a special order like Druids." ${ }^{\text {"1o }}$ Watkins included Stonehenge in his grouping of English sites that he believed were linked by ley lines, and may have been influenced by popular movements in the 1920 such as the Stonehenge Protection Committee, which sought to demonstrate the site's importance and justify its restoration. ${ }^{11}$ In any case, ley hunters and trackers were intrigued by Watkins' theories and for a while clubs associated with the discovery of these ancient lines were in vogue.

Watkins' ley lines came back into fashion in the late 196os and early 1970s when New Age authors, particularly Guy Underwood and John Michell, incorporated them into grander theories about the energy of the earth. At this point in history, the human race had witnessed the terrible energetic power of nuclear war, but had also, because of space travel and particularly the "Earthrise" photograph taken by the Apollo 8 crew depicting the earth rising over the moon, shifted to what sociologist Joshua J. Yates has termed a new "cosmopolitanism," defined as "a growing consciousness of both the world as a single place... and humanity as

\footnotetext{
9 MacDonald, Jeffery L. "Inventing Traditions for the New Age: A Case Study of the Earth Energy Tradition," Anthropology of Consciousness 6:4 (1995): 36 .

${ }^{10}$ Hutton, Ronald. "Modern Druidry and earth mysteries," Time and Mind 2:3 (2009): 316.

1 The Stonehenge Protection Committee's 1927 Appeal can be found, as of August 18, 2011, at http://www.savestonehenge.org.uk/192osappeal.html.
} 
a single people." ${ }^{12}$ The Earthrise photograph was taken in 1968 and both Underwood and Mitchell's relevant books were published in 1969, perhaps responding to a new sense of a unified earth. Energy could destroy, but these authors sought to demonstrate that it could also heal and envelop the entire planet.

Underwood's work linked ley hunting with archeology and dowsing, and he claimed that unusual patterns of energy and sources of water could be found at sacred sites. MacDonald contends that Michell's work was especially significant. He writes:

In Michell's view there was once an ancient society, which he equates with Plato's Atlantis, of great scientific and magical power which harnessed terrestrial and celestial energies by means of standing stones and circles and other sacred sites linked by ley lines which channeled these forces...He equates this power with Wilhelm Reich's orgone energy, the life force, prana, Chinese chi energy, Reichenbach's odyle force, and pyramid energy. ${ }^{13}$

Michell's approach, which took many different ideas about energy from multiple cultures and religious traditions into account, appears to be very compatible with religious creativism. There is also a clear association between energy in the earth and energy, like chi, located within the human body. In addition, Watkins' ideas, which were limited to the English landscape, were extended through Michell's conclusions. Ley lines, it turned out, were not limited to England, but were found everywhere on Earth, crisscrossing and linking sacred sites across the planet.

Adrian J. Ivakhiv's book Claiming Sacred Ground: Pilgrims and Politics at Glastonbury and Sedona, connects the ideas of Watkins and Michell to the descriptions of sacred places made by psychic Page Bryant. Bryant's work identified different type of energy 'vortexes,' identified through intuition, known as 'power spots.' These include electrical, magnetic, and electromagnetic vortexes, with each type being ideal for different types of soul work. Magnetic vortexes, for instance, encourage meditation and healing, while electrical vortexes stimulate the pilgrim. ${ }^{14}$

There are clear and obvious connections between creatives' interpretations of pilgrimage sites and 2oth century New Age notions of energy spreading across the earth in ways that call to mind the lines and cables

\footnotetext{
${ }^{12}$ Yates, Joshua J. "Mapping the good world: The New Cosmopolitans and Our Changing World Picture," The Hedgehog Review 11:3 (2009): 7.

${ }_{13}$ MacDonald, "Inventing Traditions for the New Age," 38.

${ }^{14}$ Ivakhiv, Adrian J. Claiming Sacred Ground: Pilgrims and Politics at Glastonbury and Sedona. Bloomington: Indiana University Press, 2001, 29-30.
} 
that make up the contemporary power 'grid.' Some of these influences arise from earlier centuries, however. In 1890, a generation before Watkins named his ley lines, across the English Channel in France and about a century before Bryant associated sacred places with energy types, the Abbot Bouly, curate of Hardelot, coined the term 'radiesthesia' to describe the talent that made certain people more successful than others at dowsing for water. New Age manual Pendulum Power, written by Greg Nielsen and Joseph Polansky, explains:

The name is a combination of the Latin radius for 'radiance' and the Greek aisthesis for 'sensitivity.' The word dowsing is often used interchangeably with radiesthesia but inappropriately so. Strictly speaking, dowsing refers to 'the search for water or minerals with a divining rod or pendulum', whereas radiesthesia covers both detecting and measuring the entire spectrum of radiations whether mineral, plant, animal, or human. ${ }^{15}$

This French approach to subterranean radiations links human energy to earth energy long before Michell published his views, and seems to have a stronger link to stories of Rocamadour's special qualities told by my informants.

One of my informants, Sophie, the middle-aged niece of Leona, related her experiences with a radiesthésiste in the 1950s, when she was twelve years old. She had, she told me, started to have strange abdominal pains. An initial diagnosis of appendicitis turned out to be inaccurate and the pains continued, with her regular doctor unable to make a diagnosis. Finally her mother took her to see the 'healing woman' who lived near the town. This woman hung a pendulum over Sophie's abdomen and announced that she had kidney stones. Armed with a diagnosis at last, Sophie and her mother returned to the doctor, who wanted to operate. They decided to wait on the operation and returned to the radiesthésiste, who rubbed some sort of cream on Sophie's belly. Sophie said she could feel how warm it was and then, suddenly, the pains stopped. She concluded triumphantly that the healing woman had dissolved the stones without surgery.

Leona informed me that she had once asked about the 'healing woman's' background as a radiesthésiste. She explained to Leona that she learned of her own healing powers while shopping one day when another woman in the store kept encroaching on her space. When she asked the woman

\footnotetext{
${ }_{5}$ Nielsen, Greg and Joseph Polansky, Pendulum Power: A Mystery You Can See, a Power You Can Feel. Vermont: Inner Traditions International, 1987, 10.
} 
what she was doing, the woman told her that when she came close to her, her pains stopped. This healing woman, who died in the late 1980 os before I came to do field work in Rocamadour, was clearly described as a radiesthésiste, but my subjects uniformly characterized her area of expertise as the energies of the human body rather than the energies of the earth.

My informants claimed that physical closeness to the 'healing woman' made them sense changes in pain and caused her to sense the presence of medical problems. A belief in human sensitivity to alleged energies within persons appears to be related to a similar belief in bodily or somatic sensitivity to geographical places and features. While scientists use technology to identify places that give off particular energies, those interested in earth energies from an esoteric perspective maintain that they rely on physical feelings that vary based on the person's closeness to a source of energy. Traditional explanations of dowsing rods, for example, state that the dowser must be aware of these sensations. Nielsen and Polansky claim that all living things are surrounded by energy, some of which is positive and some of which is negative. Since, they assert, negative energies tend to be harmful and positive energies tend to be beneficial, the "ability to sense and distinguish different energies is a fundamental property of protoplasm. ${ }^{36}$ Even plants, in this view, grow away from negative and toward positive forms of energy.

The notion that humans, like other forms of life, are capable of attraction to positive energy sources and repulsion from destructive energy sources is a fundamental belief underlying creativist pilgrimage. Jean Shinoda Bolen's work, Crossing to Avalon, covers her journeys as a pilgrim to places like Chartres and Glastonbury, discusses goddesses from Hinduism and ancient Greek tradition, and considers the religious traditions of many groups, from Native Americans to Celts. Much of her enjoyment of varied sacred sites comes from her somatic experiences of them, specifically, her perceptions of the energies found in these holy places. She describes her encounter with energies at Chartres Cathedral in this way:

I found that I was not taking things in primarily with my eyes and mind anymore. I was instead feeling my way, perceiving the energies in the cathedral with my body, responding to the place kinesthetically. For the first time in my life, I felt myself acting like a tuning fork or a dowsing rod. I was aware of something that was neither pressure nor vibration nor warmth, yet seemed to have qualities of all three, centered in the middle of my chest between

\footnotetext{
${ }^{16}$ Ibid., 27.
} 
my breasts and radiating in all directions. As I walked through the cathedral, I found that what I began to think of as 'the tuning-fork effect' was greater in one place than the others. When I stood at the intersection between the nave and the transepts in a cordoned-off altar area, the intensity was the greatest. ${ }^{17}$

While Bolen later describes this feeling as coming from the "divine spirit... incarnate" ${ }^{\prime 18}$ at all sacred places, she also attributes this effect to telluric currents. ${ }^{19}$ Among my religious creative informants there was a strong tendency to mix ideas of energy with ideas of spirit in a very similar way.

"Performing the Divine: Neo-Pagan Pilgrimages and Embodiment at Sacred Sites" by Kathryn Rountree discusses this type of physical response to the energies of pilgrimage centers, arguing that it is "through the body (that) we begin to understand spaces" ${ }^{20}$ and that Neo-Pagan rituals in these locales are frequently "the result of intuitive, somatic responses to a sacred place." ${ }^{21}$ Whether or not geophysicists and others agree with pilgrims that particular sites are flooded with telluric forces or radiation, or that some sacred places are deeply magnetized, these pilgrims argue that their physical bodies are instrument enough to rely on. They believe that science may offer useful concepts, but 'true' verification of energies comes through physical presence and subjective somatic experience.

\section{"Energies" and Geography_Magnetism and Radiation}

So far I've discussed how contemporary religious creatives' notions that certain 'sacred' sites are characterized by unusual energy are linked to universalizing ideas from the New Age movement, concepts from the 1920s about the hidden meanings of Britain's ancient monuments, and 19th century beliefs about radiation emanating from both the earth and human beings. Another influence, Renaissance and Enlightenment-era theories about magnetism, should be considered, particularly the thought that there exist magnetic energies inside the human body that can be

\footnotetext{
${ }^{17}$ Bolen, Jean Shinoda. Crossing to Avalon: A Woman's Midlife Quest for the Sacred Feminine. San Francisco: HarperCollins, 1995, 27-28.

18 Ibid., 29.

19 Ibid., 31.

${ }^{20}$ Rountree, Kathryn. "Performing the Divine: Neo-Pagan Pilgrimages and Embodiment at Sacred Sites," Body Society 12:4 (2006): 103.

${ }^{21}$ Ibid., 104.
} 
sensed and manipulated, especially for healing. R.B. Lindsay's 1940 paper "William Gilbert and Magnetism in 160o" provides a brief history of human awareness of magnetism before Gilbert. Lindsay writes that in the 13th century:

(M)any authors had paid their respects to the phenomenon with the exaggerative, mystical tendency typical of the period. Thus at various times during the Middle Ages magnets were asserted to be a cure for all sorts of diseases from toothache and headache to gout and dropsy. ${ }^{22}$

As for William Gilbert himself, Lindsay credits him with both determining that magnetism can take place between a lodestone and iron without direct contact between the two, and with the invention of the concept of the magnetic field..$^{23}$ These ideas, as well as others, made magnetism fascinating to both scientists and the lay public, and paved the way for a man whose work was plainly founded on the premise of a link between magnetic forces in the human body and overall health, Franz Anton Mesmer.

Tim Fulford, in his article "Conducting the Vital Fluid: The Politics and Poetics of Mesmerism in the 179os," discusses a belief held in the late 19th century that the animation of human and animal bodies was linked to a 'vital fluid' generally associated with electricity and magnetism that coursed through living tissue. Leyden jars, which could store and release static electricity, were applied to patients for the purported health benefits of this electricity for stimulating what Fulford describes as "an invisible fluid that either was, or was the medium for, the life principle itself." ${ }^{24}$

Mesmer's gift, at least as the healer explained it, was his ability to "transmit the vital fluid without a machine." Although his contemporaries later associated Mesmer's ability to influence his patients to something akin to hypnosis, Mesmer himself believed that he could use his hands "to send animal magnetism streaming from his body to the sufferers. Power lay not in the metal, but the man." ${ }^{25}$ This belief that the manipulation of magnetic energies in the body could influence health became mainstream (despite Mesmer's medical contemporaries dismissing it) because it allowed the lay public to heal without consulting medical authorities.

\footnotetext{
${ }^{22}$ Lindsay, Robert Bruce. "William Gilbert and Magnetism in 160o," The American Journal of Physics 8:5 (1940): 272.

${ }^{23}$ Ibid., 274.

${ }^{24}$ Fulford, Tim. "Conducting the Vital Fluid: The Politics and Poetics of Mesmerism in the 1790s," Studies in romanticism 43:1 (2004): 61.

${ }_{25}$ Fulford, "Conducting the Vital Fluid," 62.
} 
As Fulford writes, "It took power out of the doctors' hands and put it in the common people's - as a gift from nature." ${ }^{26}$

A good example of how ideas taken from scientific research can be manipulated and changed to serve a more mystical purpose (while still sounding scientific enough to impress potential clients) can be found in period descriptions of late 18 th century mesmerist J.B. Mainauduc. As Fulford puts it, "The magnetist channeled atoms through his fingers, into and out of the bodies of patients," controlling these purported atoms with his mind. The control of biological electrical power through the force of will had been linked to biological studies of electricity-conducting fish, like the eel and the torpedo fish. ${ }^{27}$ Mesmerists like Mainauduc argued that life was electric and if lower orders of animals could control their biological electromagnetism, then so could people.

The understanding of 'animal magnetism' as the animating energy and source of life in human beings outlasted Mesmer and other magnetic healers and was almost certainly an influence on the Abbot Bouly's idea of radiesthétisme and similar geobiological concepts that claim that energies flow through the human body and the surface of the earth, changing and affecting each other.

Whether radiesthesia is a (rather dubious) scientific concept or a (rather unorthodox) religious concept is an interesting question. The concept of a kind of radiation that emanates from people or places and causes biological change certainly sounds removed from the realm of religion. However, if 'biological change' is expanded to include spiritually influenced cognitive change (keeping in mind that the French word ésprit means both 'mind' and 'spirit'), then even one of Rocamadour's resident priests had a somewhat supernatural perspective on radiation.

In an interview with Rocamadour's Abbot Delorme that took a detour into a discussion of psychic phenomena, he contended that humans don't see the stars in the heavens - all we see, in fact, is the radiation they give off through light, and we perceive the stars themselves through this radiation. So, he continued, everything in our perception comes to us through radiation, and when we are born our brains are bombarded with it. This gives us the knowledge of everything in the world, since everything gives off radiation. People who appear to be psychic, he held, are merely adept

$\begin{array}{ll}{ }^{26} & \text { Ibid., } 67 . \\ { }^{27} & \text { Ibid., } 68 .\end{array}$ 
at accessing the information already imprinted in their brain by this radiation. He concluded that since not everyone has this ability, it is the duty of scientists to learn how to access the hidden information in our minds and make it available.

Another Amadourien informant, Nadia, a shopkeeper who sold (and explained the healing properties of) gemstones, also understood 'energy' as simultaneously natural and supernatural, and combined certain esoteric beliefs with a more traditional, devout participation in the Catholic church. In May 2007 I interviewed her in her shop, asking her about the way gemstones could heal people and whether their power was linked to magnetism. Nadia explained:

They're linked to the energies. Magnetism at its base is energy, a very strong energy. All the very strong religious centers were built on equally strong sites. Because that's it, it's the energy of a place that transcends. It transcends prayer and transcends the thoughts of people. [Awareness of this energy] is natural... Everyone has the potential but not everyone develops it because they don't understand it, they don't get to where they can understand it. But everyone will be able to do it someday.

Nadia's description of site-specific energy at sacred places was a bit diffuse. Energy came from nature, from people's prayers and thoughts, from God and from everything else. It was especially strong at Medjugorje. Nadia struggled with making me understand what she meant:

It's linked to the mountain, it's linked to water, it's linked to the mountain, it's linked to telluric forces, to the light of the Cosmos, the sun. That which transcends and that which, through the force of these energies, guides — why, yes! — the thoughts of people! If you take the oldest churches, whether Roman or gothic, this is what they're built upon. Some are open to this, others not. The only problem is we don't speak about it the same way... Everything is linked.

Both Nadia and Abbot Delorme described physical forces, radiation in his case, 'energies' in hers, that touch and affect the human body in some way, especially mentally. For Delorme, radiation comes from everything in the world and the universe and is the source of all our subconscious knowledge. For Nadia, the energies of sacred places influence people's thoughts and, in some cases, induce them to build shrines in particular places. I would argue that for each, energy and radiation are to be understood both scientifically and religiously and must be seen from both perspectives to be accurately understood. 


\section{The Use of Energy at Sacred Sites}

Clearly, many people believe that sacred sites, Rocamadour included, are possessed of unusual energies, that these energies can and do affect parallel energies within the human body, and that, to some extent (as Mainauduc argued) human will can influence this process. So how is human will involved from the perspectives of pilgrims to places like Rocamadour? How does one interact with these energies and to what extent can a person maintain control?

I came across very few cases of pilgrims choosing to work in an active way with Rocamadour's energy. These cases mostly involved people 'reaching into' the ground or the cliff itself to draw the energy of the place into themselves then either using it within their bodies or directing it elsewhere. In May of 1999 a group of Wiccans enacted a ritual at Rocamadour during which they invoked the 'goddess of the sea' as water dripped from the cliff, with the leaders guiding the group to pull the energy of the earth up through their feet, spiraling, then out through their heads, into the sky and then back down through their bodies into the earth again. This ritual served to purify and to better align the Wiccan pilgrims with the energy present at the site.

The only other case I am aware of, in which a person purposely focused and moved energy at Rocamadour, was a woman who decided to purchase a statue of the Virgin Mary in Rocamadour's religious bookstore. When told that the statue she held was the floor model and a new one would be brought to her from the back, she insisted on the one in her hand, stating that she had "filled it with energy."

Much more often, at least at Rocamadour, accessing the energy associated with a sacred site doesn't require a pilgrim to do much of anything. I have come to describe this passive reception of energy as 'basking,' since it resembles the act of a person basking in sunlight or in front of a warm fire. ${ }^{28}$ Mere proximity allows the energy from a light or heat source to be absorbed by the person basking within it, causing physical changes like the heating of the body's surface or the production of melanin within the skin. From pilgrims' descriptions, simply being present at a sacred site allows its energy to move into a person, changing them in desirable ways.

\footnotetext{
${ }^{28}$ Weibel, "Of Consciousness Changes," 122.
} 
A formerly Christian Science pilgrim, the American religious creative 'Lena,' believed the energy at Rocamadour caused a change in her consciousness, similar to what she experienced regularly by doing yoga. In yoga, the act of stilling the mind while undertaking different physical positions allowed her consciousness to shift, but at Rocamadour, she didn't need to do anything but sit and allow the energy of the place to cause this change. In our January 1999 interview, Lena described a visit to Rocamadour she had undertaken about ten years earlier. She told me that she just sat in the chapel of the Black Madonna and let the energy move over her. She saw her absorption of Rocamadour's energy as being soothing and healing, and claimed that it had cured her of previously held suicidal impulses.

The pilgrims from the esoteric Christian group Invitation à la Vie, believed that prayer allowed human beings to channel energy back into the earth, but that even tourists, unconscious of the benefits they were reaping, were changed in spiritual ways by their exposure to the energy of Rocamadour and other sacred sites. They believed that living at Rocamadour as I was doing my fieldwork was reinforcing me spiritually and strengthening my soul. I didn't need to have any intent or will involved; my being at the shrine was enough.

Many pilgrims I met or heard about were more active in their passive approach to 'basking,' taking great pains in their attempts to absorb the energy of Rocamadour. I mentioned above the tales of pilgrims leaning against the cliff wall or meditating in front of the Black Madonna statue to expose themselves to its beneficial radiation. Sometimes this 'radiation' was described as coming from thousands upon thousands of absorbed prayers. At other times, interestingly, the radiation was described as taking the form of microwaves.

The notion that the Black Madonna of Rocamadour emitted microwaves was first presented to me by an elderly couple from Belgium that I encountered in May 1999, carrying a device with them as they explored the sites. It looked like a ruler taped to a metal geometry compass and was held with the ruler part sticking up. When I inquired, they explained that the device was a radiesthetic instrument for measuring microwaves, and that at Rocamadour most of the energy radiated from the statue. The man complained that human beings were making too many artificial microwaves nowadays, making it difficult for radiesthetists to locate the genuine ones. 


\section{Using Science to Describe Religion}

What is the appeal of reinterpreting a traditional religious site with its own orthodox history in terms of ideas gleaned from science and then modified? For religious creative pilgrims, an incredibly diverse group whose religious leanings tend toward the idiosyncratic and who see all religions as potential sources of truth, the notion that some sites have amazing, life-changing, yet theoretically measurable energies has great power. For one thing, it validates the creativist tendency to group all religions together as true and interchangeable. For another, it permits creatives to see their truths as rooted in something more than just faith (the creatives I've interviewed have frequently contrasted themselves with the orthodox pilgrims to particular shrines, seeing the latter as blinded by dogma to the authentic natures of their sacred sites). Finally, it assists creatives in an overarching project (shared with many in the generalized New Age movement) to reconcile science with religion. To do this, concepts from both must be modified.

As scientific findings and concepts make their way from journal articles into mainstream understanding, sometimes these findings are erroneously modified to make them fit better with what the public expects or desires. According to science historian A. Bowdoin Van Riper, this kind of shift is especially noticeable in popular culture, like literature and the movies. Van Riper writes that "(p)opular culture probably does more than formal science education to shape most people's understanding of science and scientists," but that "(m)ainstream popular culture ... creates exceptions to natural laws, or ignores them altogether, whenever they threaten to conflict with the story being told." ${ }^{29}$ Among religious creative pilgrims, mysterious magnetism or radiation interacts with humans in ways that are completely contradicted by findings based on the scientific method, but their inaccurate understanding of electromagnetism, for example, is necessary for their 'stories' of spiritual enlightenment or wondrous healing.

If science is an uneasy ally in the creativist dispute with religiously orthodox interpretations of sacred places, helping to provide alternative explanations for a site's extraordinary qualities, it can also be an enemy. Andreas Grünschloß discusses a group whose attitude toward science is

\footnotetext{
${ }^{29}$ Van Riper, A. Bowdoin. "What the Public Thinks it Knows About Science." European Molecular Biology Organization Reports 4:12 (2003): 1104.
} 
quite similar to that of religious creative pilgrims, people who believe ancient civilizations like the Egyptians and Mayans were visited by extraterrestrials known today as the "Ancient Astronauts." Grünschloß argues that the 'science' espoused by his subjects (following the writings of Erich von Däniken) is heavily influenced by the work of Charles Hoy Fort, known for using "empirical data, which he collected from magazines, books, journals, newspapers, etc., and which had been slighted by modern science." ${ }^{\prime 30}$

Fort, who lent his name to the adjective 'fortean,' was critical of mainstream science, which he saw as unfairly exclusionist. Grünschloß notes that one of the heroes of the Ancient Astronaut devotees is Heinrich Schliemann, who ignored the mainstream dismissal of Troy and, relying on ancient texts for guidance, was able to uncover its ruins. ${ }^{31}$ This inclination to see science as so corrupt and restricted that it misses the greater truths is part of the popular culture impression of science as well. Van Riper writes that "(s)tories about 'crazy' ideas and their defenders have been common in popular culture for centuries, supplying drama when the hero is ridiculed, and a satisfying ending when he is vindicated." ${ }^{2}$

The scientific claims of religious creative pilgrims, then, do not have to fit within the boundaries of modern science in order to supply their believers with a patina of scientific credibility. Grünschloß refers to this approach as "fantastic science," arguing that its proponents have certain characteristics in common, like having an attraction to the unexplained, desiring a popular uprising against mainstream science, simplifying the scientifically complex, naturalizing religion through euhemerism and scientific reasoning, and focusing on integrating religion and science. ${ }^{33}$

Those religious creative pilgrims who claim that certain locales are sacred because of the presence of magnetism, atomic energy, microwaves, unidentified energies, and other physical/spiritual forces, express ideas that fit very neatly into Grünschloß' "fantastic science." An affiliation with science and its reputation for cool objectivism is useful for creatives when they contrast themselves with the conventionally religious, but when scientific objectivity discredits their subjective personal experiences, its glaring inadequacies become obvious. Creatives believe, however, that

\footnotetext{
$3^{0}$ Grünschloß, Andreas. “'Ancient Astronaut' Narrations: A Popular Discourse on Our Religious Past," Fabula 48 (2007): 3.

${ }^{31}$ Ibid., 6.

${ }^{32}$ Van Riper, "What the public thinks it knows," 1107.

33 Grünschloß, “'Ancient Astronaut' Narrations,” 12-13.
} 
science does lead to truth and will eventually, when wrested from corrupting forces, prove their claims.

In the meantime, a belief that all sacred sites, whether Christian, Buddhist, Muslim or American Indian, share a common origin (a universal 'undercurrent,' perhaps?) provides strong rhetorical force for the creativist argument that all religions are true and equivalent. Seeing the earth as a singular blue ball in space allows a perspective on humanity that transcends a lot of long-held divisions. Religious scholar Paul Heelas notes that New Age thinking (which is often creativist) is "profoundly inclusivistic." He sums up the New Age worldview thus: "We are all essentially one; all religions point to the same truth; the globe is a whole; unity prevails within diversity." ${ }^{34}$ From this standpoint, all of the world's religions are based on the same reality, but variations arise due to positive things like culture and negative things like human weakness, leading more and more differences and conflict to arise. An origin story for sacred places explaining that some parts of the planet have strong, beneficial energies that human beings respond to, consciously or unconsciously, and interpret in terms of spirituality, allows religious differences to be dismissed as superficial and religious sites to be open and available to all who are drawn to them.

\section{Science, Religion and the Subjective Experience of Place}

The language of science can give an air of legitimacy to a pilgrim's claims about the reason for a site's sacred status, even if these claims fail to stand up to academic scrutiny. Academic approaches can, however, shed light on some of the subjective experiences of these pilgrims, giving insight into the relationship between the human body, religious belief, and geographical locations. In this section I will examine a few concepts on how human responses to places and the religious interpretation of these responses can be considered from the perspectives of neurobiology, evolutionary biology, and cognitive science.

One common idea among my informants, discussed above, was that certain places had unusual energies that could be physically sensed (at least by some) and that the resulting unusual sensations or bodily experiences were interpreted as signs that a site was divine or spiritually important in

${ }^{34}$ Heelas, Paul. The New Age Movement. Oxford: Blackwell Publishers, Ltd., 1996, 219. 
some way. Subjective sensations (pain, for instance) are notoriously difficult to describe and almost impossible to convey accurately to anyone not feeling them. Sensations experienced by my informants may have been real, imaginary, or psychosomatic.

Some of these feelings may be tied to the physical structure and function of the brain. Notable work about the way different parts of the brain's anatomy inform religious belief has been discussed by Carlos Fayard, Melissa J. Pereau and Antonia Ciovica in their article "Love the Lord With All your Mind': Explorations on a Possible Neurobiology of the Experience of God and Some Implications for the Practice of Psychotherapy." Although this article takes a Christian perspective (calling into question its scientific objectivity) it approaches the question of the brain's role in religion from a perspective that weds psychology with neurobiology.

Fayard et al. make the claim that human belief in the divine is hardwired, but that "(c)ulture and human choice, however, will determine the nature of the god to be experienced." 35 Their major theory is that religious belief depends upon three biologically-based psychological processes: the Seeking System, the Attachment System, and Theory of Mind. Briefly, seeking is tied to dopamine transmission and creates a feeling of spiritual longing in the individual. Attachment, which "provides the template for what it feels to be close to someone, ${ }^{36}$ comes both from the psychological attachment to the parents, and physiologically, from circuits between the amygdala and the limbic and higher cortical regions as well as dopaminergic and opioid responses to mother-child interaction. Theory of mind is defined as "the attribution of human properties to all perceived intentional agents" 37 that "builds on circuitry responsible for the development and maintenance of attachment experiences and connects to higher cortical areas where cognitive processes categorize and organize systems of belief." ${ }^{38}$

Although their three-part model is theological and was created to be a tool in the clinical practice of psychology, their ability to link subjective experiences and neuroscience may illuminate some of the experiences of

${ }^{35}$ Fayard, Carlos, Melissa J. Pereau and Antonia Ciovica, "'Love the Lord With All Your Mind': Explorations on a Possible Neurobiology of the Experience of God and Some Implications for the Practice of Psychotherapy," Journal of Psychology and Christianity 28:2 (2009), 167.

${ }^{36}$ Ibid., 174 .

37 Ibid., 175 .

$3^{8}$ Ibid., 176. 
creativist pilgrims. It posits a situation in which the supernatural force in question evokes a very human response in which religious experience echoes the feelings present in social relationships. For Fayard, Pereau and Clovica, the experience of the divine requires a personal god, an entity that is, if not human, at least similar. Their model may explain the subjective sensations of orthodox pilgrims to Lourdes, for example, who feel the presence of Mary there, but it does not seem to account for those religious creatives who seek to absorb powerful, divine radiation from geographical sites.

Another way to frame certain pilgrims' experience at shrines in terms of neurobiology relates to the perception of stimuli that appear to bypass our normal sensory systems. The shrine of Rocamadour has characteristics that may also create unusual sub-auditory impressions. In a personal communication with Donald Tuzin, author of the 1984 paper "Miraculous Voices: The Auditory Experience of Numinous Objects," he suggested to me that perhaps the large cliff face that hangs over the Alzou Canyon, embracing Rocamadour's collection of churches like a pair of outstretched arms, could be having an effect on sound waves at the shrine, distorting them and causing pilgrims (and others) to report strange sensations. I have not been able to test this, and I am unaware of similar conditions at other pilgrimage sites, but if this were the case and infrasonic waves were in fact produced by the interaction of ordinary sounds with the cliff face, it might explain some of the unusual 'vibrations' described by my informants. ${ }^{39}$ Tuzin writes, "By definition, infrasonic waves are not heard; they do not excite the auditory nerve in the manner of audible sound... Infrasonic vibrations assail the entire body; but because the sensation is vibratoryas is normal sound - the feelings we report, and the idioms we employ in describing it are recruited from the realm of audition." ${ }^{40}$ Tuzin goes on to describe the resultant sensations as "uncanny" and "alien." It is possible, following Tuzin, that some of the energies described by my informants

\footnotetext{
39 According to Mark Purdey, "parabole shaped mountain valleys or coastal cliffs can refract and channel incoming prevailing infrasonic waves (radiating from windstorms, oceanic waves, thunderstorms, explosions, etc.) into wind tunnels so that they converge to form acoustic beacons of concentrated infrasound at spot locations" (Purdey, Mark "Does an Infrasonic Acoustic Shock Wave Resonance of the Manganese 3+ Loaded/Copper Depleted Prion Protein Initiate the Pathogenesis of TSE?" Medical Hypotheses 60:6 (2003): 797-820, (page 808)). Rocamadour is, in fact, in the part of France where the Mistral winds blow, and I was told by informants that they made people moody.

${ }^{40}$ Tuzin, Donald. "Miraculous Voices: The Auditory Experience of Numinous Objects," Current Anthropology 25:5 (1984): 586-587.
} 
may be infrasonic waves that have been misidentified as microwaves or magnetism.

Research in the field of evolutionary biology suggests that a significant component of pilgrims' positive responses to particular shrines (especially those with a strong natural component, like Rocamadour) may in fact be positive responses to particular qualities of landscapes. C.U.M. Smith in the article "Evolutionary Neurobiology and Aesthetics" argues that an appreciation of beautiful places may be universal and therefore have a neurobiological origin. The appreciation of something beautiful happens rapidly and unconsciously, resulting in a conscious sense of pleasure. ${ }^{41}$ Smith notes that evolutionary biologists "have sought... to tie the aesthetic quality of certain natural scenes to feelings of health and well-being," ${ }^{42}$ which may certainly be part of the reason that pilgrims to particularly beautiful pilgrimage centers report being cured of illness or transformed in some way.

A sense of happiness and well being, however, is not necessarily the same as a perception of 'energy.' Smith acknowledges that other feelings may be produced, writing that some "features of landscape...include elements of 'mystery' that draw people closer to investigate, such as "the winding path ... that goes out of sight behind a clump of trees or a hillock, or proceeds over the horizon." ${ }^{43}$ While it is likely that Rocamadour's beauty or the nature of its rising cliff, undulating with mysterious caverns and ridges, has an aesthetically positive impact on those who view it, it may not be enough to generate the sense of energy that creativist pilgrims so often describe.

In "Religion's Evolutionary Landscape: Counterintuition, Commitment, Compassion, Communion," Scott Atran and Ara Norenzayan approach the issue of religion and the mind from a more cognitive perspective. They contend that religion can be defined as "passionate communal displays of costly commitments to counterintuitive worlds governed by supernatural agents." ${ }^{44}$ Although they acknowledge that the ethnographic record always locates exceptions, they argue for the well-known cognitive theory that certain features that evolved in the human brain were important to

\footnotetext{
${ }^{41}$ Smith, Christopher U.M. "Evolutionary Neurobiology and Aesthetics," Perspectives in Biology and Medicine 48:1 (2005): 18.

42 Ibid., 21-22.

43 Ibid., 22.

${ }_{44}$ Atran, Scott and Ara Norenzayan, "Religion's Evolutionary Landscape:Counterintuition, Commitment, Compassion, Communion." Behavioral and Brain Sciences 27 (2004): 713.
} 
our survival, but could also be shifted to make religious beliefs and understandings possible. For instance, they claim that because early humans had to watch out for predators or prey, "... there is culturally conditioned emotional priming in anticipation of agency. This priming, in turn, amplifies the information value of otherwise doubtful, poor and fragmentary agency-relevant stimuli." This means that "supernatural agents are readily conjured up because natural selection has trip-wired cognitive schema for agency detection in the face of uncertainty." 45

In other words, humans believe in supernatural entities because we look for agents. When something happens, good or bad, we expect there to be something intentional behind it. When disasters strike or apparent miracles take place, we attribute them to supernatural personae who intend for them to happen. When healing (or the evolution of the soul, for that matter) is attributed to a divine energy, however, an impersonal energy that benefits the believer and non-believer alike, agency seems to be a minor consideration. Sometimes agency is given to the energies my informants describe, sometimes it isn't. Something else must be at work here.

\section{Religion, Place, and Metaphor}

Sociologist Robert Wuthnow has made the case that although claims about religion from the domains of neuroscience and cognitive science are interesting (and controversial), many assertions from these realms "are only remotely relevant to empirical work in the social sciences," ${ }^{46}$ being less preferable perhaps than analyzing religion in terms of schemas, narratives and metaphors. Metaphors, for instance, "do not only reflect cognitive domains, but rather define and reinforce them." ${ }^{47}$

Linguist George Lakoff and philosopher Mark Johnson in their classic Metaphors We Live By, suggest that human beings better understand abstract concepts when they are framed using familiar ideas. They say that human "experiences with physical objects (especially our own bodies)" help create ontological metaphors that permit us to see "events,

45 Ibid., 720.

${ }^{46}$ Wuthnow, Robert. "Cognition and Religion," Sociology of Religion 68:4 (2007): 343 .

${ }^{47}$ Ibid., 348. 
activities, emotions, ideas, etc. as entities and substances." ${ }^{48}$ They note that the concept of 'love' is often likened to physical force, and give examples like "I could feel the electricity between us... I was magnetically drawn to her... The atmosphere around them is always charged."49

Love is an emotional experience that frequently involves a physical aspect, and I would argue that the claimed somatic experience undergone by some pilgrims at sites like Rocamadour entails a physical aspect as well. Recall Bolen's "tuning fork effect" at Chartres where she described feeling something that was somehow both like and unlike pressure, vibration, and warmth. At the same time, pilgrims are frequently profoundly emotionally involved with the sites they choose to visit (for instance, speaking of feeling ecstatic, energized, loved, etc.) and in the cosmologies of certain Wiccans and Neo-Pagans, these sites are locations for interacting with the living entity that is the Earth. It seems fair to state that for many, talk of energy, magnetism, radiation and the like provides a way of communicating ideas that are hard to describe in any other way. If love can be understood in terms of magnetism and electricity so too, perhaps, can spiritual experience..$^{0}$

This metaphor can be extended to discuss the transformative effect of pilgrimage to sacred energy centers. Martin Gray, in Sacred Earth: Places of Peace and Power argues that:

... it is highly beneficial for people to make pilgrimages to sacred sites because of the transformational powers available there. These legendary places have the mysterious capacity to awaken and catalyze within visitors the qualities of compassion, wisdom, peace of mind, and respect for the earth..$^{1}$

As ultraviolet light can stimulate the production of melanin in human skin and chlorophyll in plants, the purported energy of sacred sites, in the view of religious creatives, can catalyze positive emotional qualities. The metaphor of energy helps characterize the view that sacred locations change the people who visit them in very positive ways.

\footnotetext{
${ }^{48}$ Lakoff, George and Mark Johnson, Metaphors We Live By. Chicago and London: University of Chicago Press, 1980, 25.

49 Ibid., 49.

$5^{\circ}$ I wish to point out that the use of energy as a metaphor is certainly not limited to religious creatives. Christians use these metaphors, as do members of many religions. For example Qanta Ahmed, a Muslim pilgrim to Mecca, states in a memoir that the Ka'aba "was calling to me magnetically" (Ahmed, Quanta. In the Land of Invisible Women. Naperville, Illinois: Sourcebooks, Inc., 2008, 151).

${ }^{51}$ Gray, Martin. Sacred Earth: Places of Peace and Power. New York: Sterling, 2007, 12.
} 
Creativist pilgrims to Rocamadour and other 'sacred' locations often claim to feel something physical when visiting these sites. The subjectivity of human experience is such that it may be impossible to ever measure or quantify these sensations or to know whether they have roots in anything beyond the human imagination. Still, research into the relationship between the human body, religious experience, and geographical location indicates that landscapes can and do effect the human mind and senses and that the experience of the spiritually inclined can be examined, at least in part, by looking into the workings of their brains. Moreover, an understanding of how people use metaphors reveals that when describing strong emotions, the image of 'energy' can be particularly salient. An idea of energy that was simply metaphorical may have greater utility as an energy-based schema or mental model due to its capacity to reinforce certain human physiological and psychological responses to particular geographic locations while also serving an important rhetorical function.

Pilgrims who describe shrine sites like Rocamadour as places of extraordinary 'energies,' therefore, are not merely using language that reflects subjective, somatic experience. They also stake a claim to the locale in question and legitimize pilgrimage activities by those whose nonorthodox status might otherwise exclude them. The broader scientific context of Western society has provided creativist pilgrims with language and concepts (like radiation, magnetism and microwaves) that, re-imagined in such a way to emphasize the oneness of what they see as 'true' religion and 'true' science, provide them with validating and universalizing schemas for interpreting pilgrim destinations. 


\title{
SCIENTIFIC APPROACHES TO THE BODY IN THE SPIRITUAL-PHYSICAL MARKETPLACE
}

\author{
Mira Karjalainen
}

Everything that we do, we do in our bodies; therefore also spiritual and religious experiences inevitably are bodily experiences. Yet, if spirituality and religiosity are always profoundly embodied practices, how should we view such practices that consciously involve the physical body as a medium of spiritual growth? While research is starting to recognize the need to study spiritual embodiment, little attention has been paid to practices that approach spirituality through the body.

This chapter looks at embodied spiritual practices in physical exercises, giving a special attention to those exercises related to religious traditions. There are number of globally popular physical leisure activities that are connected to religions: yoga with Hinduism, and a variety of Asian martial arts - from Chinese taijiquan to Japanese karate-with Buddhism, Confucianism, Daoism, and Shinto. While their approach to religion varies, all these exercises enable their practitioners to experience spirituality through embodiment. These exercises illustrate the complex relations of spirituality, the body and the practice of physical exercises in late-modern urban cultures. 'Spirituality' is employed here as a different, but not entirely separate concept from religiosity: religiosity refers to more conventional forms of devotion, mostly within an established religion; spirituality emphasizes the personal unique experiences and practices whose importance and meaning are defined by the individual. ${ }^{1}$ With regard to embodiment, this means that one is aware of one's body and its sensations, and views them as genuine (re)sources for knowledge and experiences.

\footnotetext{
${ }^{1}$ The literature on sociology of religion still fails to establish the relationship between concepts of spirituality and religiosity, as there are five possible relationships between these two concepts, according to Eileen Barker (Barker, Eileen. "The Church Without God and the God Within: Religiosity and/or Spirituality?," In The Centrality of Religion in Social Life, edited by Eileen Barker. USA: Ashgate. 2008, 187-202). First, spirituality and religiosity are synonymous and thus interchangeable. Second, spirituality is a subsection of religiosity, among others. Third, religiosity is a sub-division of spirituality. Fourth, spirituality and religiosity are two entirely separate concepts. And finally, spirituality and religiosity are overlapping concepts and they share some but not all characteristics.
} 
Often the spiritual path first starts with a back-ache or need for exercise rather than with a search for meaning-typical examples are taijiquan and yoga. Thus contemporary spirituality encompasses also pragmatic concerns and does not frown on this-worldly problems, such as health issues or stress relief. Body is seen as a gateway to the depths of inner life, and therefore it is also understood as a resource, or a way for attaining greater well-being. These spiritual-physical exercises are based on the principle that the human body allows privileged access to one's spirit and emotions. ${ }^{2}$ Contemporary spirituality thus begins with physical embodiment.

At present, there are two major tendencies in the field of physical exercises. One is the current trend of body management and maximum efficiency that leans on the scientific approach to a body and borrows rhetoric from science in marketing: examples are body building and fitness classes like Bodypump ${ }^{\mathrm{rm}}$ or Zumba ${ }^{\circledR}$. The other is the trend of subjectivity and the associated search for individual experience and also spirituality, which emphasizes a personal approach to well-being: yoga and taijiquan, for example. These spiritual-physical exercises face pressure to transmute, as consumer culture appropriates spiritual conceptions of the body and body practices, and transforms these conceptions into new understandings of spiritualities. As part of the acculturation process to become an urban market commodity, Elizabeth De Michelis notes that exercises such as yoga have experienced a wave of endeavors for scientific validation. ${ }^{3}$

This chapter draws attention to physical exercises that approach spirituality through the body, asking what happens as these spiritual-physical exercises gradually give ground in the process of becoming part of the western consumer market, including issues of mind-body dualism and its scientific descendants. Does contemporary cultural fascination with neurobiology and health (sciences) influence the marketplace appropriation of spiritual conceptions of the body? I argue that our society's interest in neurobiology and health defines the way spiritual or therapeutic exercises are reconfigured, conceptualized, and practiced. Furthermore, this chapter discusses how the major trends in the physical exercise market come

\footnotetext{
${ }^{2}$ McGuire, Meredith. "Toward a Sociology of Spirituality: Individual Religion in Social/ Historical Context," in The Centrality of Religion in Social Life, edited by Eileen Barker. USA: Ashgate. 2008. 215-232.; Sointu, Eeva, and Linda Woodhead. 20o8. "Spirituality, Gender, and Expressive Selfhood," Journal for the Scientific Study of Religion, Vol. 47(2): 259-276.

3 De Michelis, Elizabeth. "A Preliminary Survey of Modern Yoga Studies." Asian Medicine, Vol. 3 (2007): 1-19.
} 
to merge in spiritual-physical exercises like yoga and Asian martial arts. Following this, spirituality in these exercises may become suppressed, expressed, or interpreted in new and unexpected ways. Contemporary sociology of religion is starting to understand the need to explore this phenomenon.

\section{Modernization of Spiritual-Physical Exercises and Their Attraction in the Cosmopolitan Marketplace}

As yoga and many Asian martial arts gain global popularity, they are now practiced in countries that do not share their original cultural heritage. These practices have turned into an integral part of urban cultures worldwide, as De Michelis notes on modern yoga. ${ }^{4}$ This trend raises new questions regarding the authenticity and evolvement of the exercises, and how the practitioners of other cultural backgrounds become familiar with religious traditions or negotiate the spiritual dimensions of the art into their belief systems. As a practitioner of Chinese martial arts like taijiquan eventually has to face Chinese religions if she or he wants to fully understand the art, so too will a yogi inevitably meet Hinduism and will a budoka (the practitioner of the group of Japanese martial arts called budō) meet Buddhism, Confucianism, and Shinto. ${ }^{5}$ These activities are deliberately called 'physical exercises' in this chapter, in order to emphasize their place in the cosmopolitan market where they are labeled primarily as physical activities, instead of spiritual, as they could be called in the cultures of their origin. ${ }^{6}$

Although in yoga the physical exercise is also viewed as a way that leads to deeper spiritual being and ultimately to enlightenment, according

4 Ibid.

5 Many other physical exercises are often viewed as religious and spiritual as well, for example samba and salsa share common ground with some African-derived religious traditions of Latin America, and several studies have established a link between belly dance and spirituality (see Kraus, Rachel. "The Many Faces of Spirituality: A Conceptual Framework Considering Belly Dance." Implicit Religion, Vol. 12 no. 1 (20o9): 51-72). There are also other leisure activities, such as African and Cuban drumming, that relate to religions, but for the purposes of this chapter the area of interest is confined to the abovementioned physical exercises.

${ }^{6}$ Although football (both European and American), for example, has been compared to religion and religious experience, this chapter does not take sport as a religion but looks instead into the religions interlinked with physical exercises (regarding sport's relation to religion, see e.g. Magdalinski, Tara, and Timothy J.L. Chandler, eds. With God on Their Side. Sport in the Service of Religion. London: Routledge. 2002.). 
to the teachings of Hinduism, in the cosmopolitan consumer culture religion is often downplayed and yoga is introduced as a fitness or relaxation (therapeutic) technique. Yoga generally refers to traditional intellectual and physical disciplines originating in India. Although yoga has its roots dating back to at least 1500 years to Patañjali, whom some yogis consider to be its semi-mythical founder, the history of modern yoga is a little over 100 years old. Modern yoga, as De Michelis defines it, refers to "those disciplines and schools which are, to a greater or lesser extent, rooted in South Asian cultural contexts, and which more specifically draw inspiration from certain philosophies, teachings and practices of Hinduism."

Many scholars date the yoga renaissance and the beginning of modern yoga in the West starting with Swami Vivekananda's (1863-1902) visit to the United States in 1893. Perhaps the two most influential yoga masters of our time are Pattabhi Jois $\left(1915^{-2009)}\right.$ and B.K.S. Iyengar (1918-) who both founded their own hatha yoga schools, which now enjoy global popularity: Ashtanga Yoga by Jois and Iyengar Yoga by Iyengar. These two yoga schools have developed into worldwide organizations with branches in dozens of countries in all continents; Iyengar Yoga has schools in 61 countries and Ashtanga Yoga in $26 .{ }^{8}$

Just as all yoga is rooted in Indian philosophy and mystical technology dating back at least to the middle of the first millennium $\mathrm{CE}$, the practice of asanas (the physical postures central to hatha yoga) has a shared history with the philosophical development of yoga. Philosophy in the Indian context always has soteriological goals, although yoga practice does not require worshipping Indian deities. In fact, the soteriological philosophy and the ideas regarding ultimate reality are interpreted with great variety among the many paths of yoga. The Iyengar Yoga teachers in Britain are told not to instruct others which, if any, god to believe in and to avoid making metaphysical comments. Also, although for Ashtanga Yoga the ultimate goal is to realize 'the true nature of selfhood,' the late-modern

De Michelis, "A Preliminary Survey of Modern Yoga Studies," 2.

${ }^{8}$ Burger, Maya. "What Price Salvation? The Exchange of Salvation Goods between India and the West." Social Compass, Vol. 53 no. 1 (2006): 83, 81-95; Van der Veer, Peter. "Global Breathing-Religious Utopias in India and China." Anthropological Theory, Vol. 7 no. 3 (2007): 315-328.; Lea, Jennifer. "Liberation or Limitation? Understanding Iyengar Yoga as a Practice of the Self." Body \& Society, Vol. 15, no. 3 (2009): 71-92.; De Michelis, "A Preliminary Survey of Modern Yoga Studies"; "B.K.S. Iyengar Yoga." http://www.bksiyengar .com/modules/Teacher/teacher.asp.; "Ashtanga Yoga." http://www.ashtanga.com/html/ classes.html. 
cosmopolitan context of modern yoga downplays or overlooks the transcendental dimension. ${ }^{9}$

Modernization shows also in Asian martial arts such as budō, whose religious or philosophical background comes from Buddhism, Shinto, and Confucianism. ${ }^{10}$ Budō as a generic term can be used synonymously with all Japanese martial arts, or it may refer to the modern Japanese martial arts developed since the 19th century. In the latter meaning, which is employed in this chapter, these budō are: jūdō, kendō, kyudō, aikidō and karate-dō, of which especially judo and karate - as they are usually transcribed in the cosmopolitan market - enjoy a strong international following. In budo the physical exercise is viewed both as a fighting technique and a way to spiritual growth and ultimately to enlightenment. All these above-mentioned Asian physical exercises have gone through a metamorphosis in the late 19th and 2oth centuries. Often this transformation has been about the modernization of the art to meet the social, spiritual, and philosophical ideals of the modern society."

Judo is perhaps the best example of the modernization process in Japanese budō, for during judo's history it has undergone conceivably the most severe transformation of all these exercises. It originates in jujutsu, which developed for defense purposes over a period of at least one millennium. The first wave of modernization and of westernization was introduced by the Japanese: Jigorō Kanō (1860-1938), founding judo at the end of 19th century, transmuted the traditional fighting technique of the warrior into judo, which in English means 'the Way of the pliancy', thus emphasizing the $d \bar{o}$ (Way) over jutsu (technique). He also copied modern organizational structure and ideas of efficacy from the West.

Ideologically, judo is a child of the Meiji Restoration in Japan (1868). Meiji Restoration's purpose was to unite western progress with traditional eastern values; with regard to martial arts as judo, its goal was to fuse traditional and modern perspectives in the art. 'Modern' meant, for

9 Hasselle-Newcombe, Suzanne. "Spirituality and 'Mystical Religion' in Contemporary Society: A Case Study of British Practitioners of the Iyengar Method of Yoga." Journal of Contemporary Religion, Vol. 20 no. 3 (2005): 305-321.; Smith, Benjamin R. "Body, Mind and Spirit? Towards an Analysis of the Practice of Yoga." Body \& Society, Vol. 13 no. 2 (2007): 27-28.

${ }^{10}$ Young, Damon A. "Bowing to Your Enemies: Courtesy, Budō, and Japan.” Philosophy East \& West, Vol. 59 no. 2 (2009): 188-215.

${ }^{11}$ Tan, Kevin S.Y. "Constructing Martial Tradition: Rethinking a Popular History of Karate-dou." Journal of Sport \& Social Issues, Vol. 28 no. 2 (2004): 169-192; Villamón, Miguel et al. Reflexive Modernization and the Disembedding of Jūdō from 1946 to the 2000 Sydney Olympics." International review for the Sociology of Sport, Vol. 39 no. 2 (2004): 139-156. 
example, the organization of judo into clubs and federations, while 'traditional' referred to the cultivation of spirituality, deepened sense of selfawareness, and the consciousness that is the Japanese spiritual base of $d \bar{o}$, which shows in its name. Later, the second wave of westernization and of modernization was executed in order to appeal to the spectator sports of western audiences. Since Kanō, judo has gone through great changes, as it is now an Olympic sport with its own federations, competitions, and sponsorships. Kanō was wary about the idea, contemplating that the spirit of judo could die if it became an Olympic discipline. ${ }^{12}$ Consequently, as Kevin Carr puts it regarding the modern judokas, "Sports science is a far more important 'religion' than Zen for this new brand of athlete." ${ }^{{ }^{13}}$ Thus judo lost its 'Way' when it was transformed into a sport, because in order to conform to the western taste for spectator sports, it was disembedded from its philosophical and spiritual background. ${ }^{14}$

The Chinese martial art taijiquan-also known as internal boxingwas also influenced by a similar modernization process as Japanese budō in the early 2oth century, experiencing the same fascination for western trends in physical exercise. It has already been shown that when discussing the modernization processes of Asian martial arts, one has to remember that the 'West' has not always been the culprit in mutating the arts. The political development of China set serious challenges to traditional taijiquan practice in the country during the 2oth century. Mao Zedong wanted to transmute it to an exhibition sport-the government created a 'modernized' and simplified form of it-and during the Cultural Revolution the martial artists were persecuted, sending many to flee offshore to places like Taiwan and Hong Kong. Thus in the case of taijiquan, especially, the global market has actually helped to preserve the traditional forms of the art. ${ }^{15}$

\footnotetext{
${ }^{12}$ Carr, Kevin Gray. "Making Way: War, Philosophy and Sport in Japanese Judo." Journal of Sport History, Vol. 20 no. 2 (1993): 167-188.; Villamón et al., "Reflexive Modernization"; Young, "Bowing to Your Enemies."

Chinese taijiquan tried to follow the footsteps of judo and Korean taekwondo to become an Olympic sport for the Peking 2008 Olympic Games, but the petition was rejected (Ryan, Alexandra. "Globalization and the 'Internal Alchemy' in Chinese Martial Arts: The Transmission of Taijiquan to Britain." East Asia Science, Technology and Society: an International Journal 2 (2009), 539-540). Also Bikram Choudhury, the founder of Bikram Yoga with schools in 39 countries, has applied for yoga's admission into the Olympic Games (Howe, D.K. "Could Yoga Become an Olympic Sport?" American Fitness, Vol. 28, no. 4 (2010): 44-45.; "Bikram Yoga." http://www.bikramyoga.com/studioListing.php.

${ }^{13}$ Carr, "Making Way," 182.

${ }^{14}$ Villamón et al., "Reflexive Modernization."

${ }^{15}$ Ryan, Alexandra. "Globalization and the 'Internal Alchemy' in Chinese Martial Arts"; Van der Veer, "Global Breathing."
} 


\section{The Subjective Turn in Spiritualities and Physical Exercises}

Several expressions of Asian martial arts and yoga have gained popularity in the urban world over the past few decades, "quietly entering the fabric of everyday Western life". ${ }^{16}$ Although these exercises, as imported commodities, are more predominant in North America and Europe (arguably as parallels to secularization and to the turn to the subjective, discussed in the following pages), one finds yoga, budō, and other Asian martial arts in schools in all continents, including Africa and Latin America.

There are two major trends in religion and society in the 'West' that help explain the rising popularity of these exercises: One is multiculturalism and the fragmentation of religion: as ideas, cultures, and religions diffuse globally, and the monopoly of Christianity disappears, there is space for more diverse religiosity and spirituality. And the other is secularization and its aftermath, post-secularization.

While secularization was long held to be inevitable in modern society, the rise and diversity of new religious and spiritual phenomena - such as New Age, alternative spiritualities, religious consumerism, and well-being practices-have proved this argument questionable (as has the influence of religion on politics and other spheres of society in the US). ${ }^{17}$ The phenomena of new religiosities and spiritualities may be referred to as reflections of post-secularization. Secularization gave rise to a more tolerant culture, thus enabling new religions and new religious practices. Among these were religions that had a different approach to the body than that taught by the Church. ${ }^{18}$ Since then the Christian body-soul dualism has been challenged by alternative ways of recognizing human beings and

\footnotetext{
${ }^{16}$ Brown, David, and Aspasia Leledaki. "Eastern Movement Forms as Body-Self Transforming Cultural Practices in the West: Towards Sociological Perspective." Cultural Sociology, Vol. 4 no. 1 (2010): 123 .

${ }^{17}$ Secularization theories often name dimensions of modernity-such as urbanization, individualization, rationalization, and societalization - as responsible for secularization (Woodhead, Linda. "Gendering Secularization Theory," Social Compass, Vol. 55 no. 2 (2008): 187-193). On secularization, see also Taylor, Charles. A Secular Age. Cambridge, MA: Harvard University Press, 2007; Bruce, Steve. 1996. Religion in the Modern World: From Cathedrals to Cults. New York: Oxford University Press.

18 The focus of religious embodiment, however, Meredith McGuire states, is by no means a novel turn in the history of Christian religiosity. Rather, the disconnection of embodiment and religiosity is a relatively new phenomenon in the West. The Reformation's privileging of belief over practice in definitions of religion and thereby of bodies was almost entirely pushed aside in the conceptualization of religion. (McGuire, "Toward a Sociology of Spirituality").
} 
their bodies. In physical exercises originating in Asian culture, especially, there are different takes on embodiment.

While spiritual practices are always embodied, in yoga, budō, and the other Asian martial arts the physicality of human beings is a basis for the exercises and their spiritual dimension. These exercises have gained popularity in the wake of the turn toward the subjective. Experienced since 196os, this is a turn away from life that is lived obeying external or 'objective' roles, duties, and obligations that are given to us by culture and society. Instead, one turns into oneself, to 'subjective life' in which the significance of things do not rise from external matters (for example, how something is valued in the community, workplace or church with which one is connected). Rather, significance rises from the unique experiences of self, when life is lived in deep connection with one's own personal experiences. In religion this means that an individual does not look for answers in authority, institution or dogma, but turns attention to the inside; into one's own emotions, experiences and longings. 'Spirituality' may also include the everyday spiritual lives of ordinary people. ${ }^{19}$ Accordingly, religious practices may evolve to something different than institutionally established conventions; dancing, gardening, jogging, or painting may represent one's spirituality, as well as exercises originating from other, 'exotic' cultural backgrounds.

The subjective turn shows not only in spirituality but also in physical exercises. When earlier the variety of physical exercises one could choose from was rather limited, now the repertoire of leisure time activities and exercises is more wide-ranging than ever. Individuals can choose their exercise according to their physical, mental, social, and sometimes spiritual needs of the time. Since popular physical exercises such as yoga, judo and taijiquan are now practiced around the world, they are taught and perceived in new and sometimes unconventional ways in relation to their religious and philosophical backgrounds. The subjective turn, with its experience-oriented approach to leisure time and spirituality, unavoidably affects the appeal of these physical exercises in urban cultures worldwide. In spiritual practices involving the body, Sointu and Woodhead argue, the body is a medium to access one's authenticity, or the inner 'core', reflecting one's true feelings and thoughts—one's spirit. In case of judo, taking

${ }^{19}$ Heelas, Paul, and Linda Woodhead. Spiritual Revolution: Why Religion is Giving Way to Spirituality. Malden, MA: Blackwell. 2005.; McGuire, Meredith. "Why Bodies Matter: A Sociological Reflection on Spirituality and Materiality." Spiritus: A Journal of Christian Spirituality, Vol. 3, no. 1 (2003): 1-18. 
into account post-secularization and the subjective turn, it is perhaps not so surprising that it is the western judokas who are now calling for getting the Japanese spiritual base ' $d \bar{o}$ ' back to judo. ${ }^{20}$

\section{The Mind-Body Dualism and Scientific Approaches to the Body}

Although modern-day spirituality commonly starts with bodily experience, science and consumerism have permeated contemporary culture so thoroughly that it is not surprising that in one's concern for health, and health-related spirituality, the rhetoric of science is often both appealing and persuasive.

The scientific project of yoga, together with its 'medicalization' began in 1920's India, when attempts were made to bring together modern science and spiritual aspects of yoga. Vivekananda, who is considered a key figure in the introduction of many Hindu philosophies in the West, had already marketed yoga as a scientific tradition to westerners, and the emphasis on mind-body unity in hatha yoga (which in the cosmopolitan market is usually associated with the physical tradition of postural yoga) in particular, offered a popular alternative choice to Americans. Vivekananda's yoga did not specify any religion to adhere to; instead it claimed to be both eastern spirituality and rational science. ${ }^{21}$ Swami Kuvalayananda (1883-1966) was the first to carry out laboratory research on yoga's health effects, believing that the classical yogic literature revealed the truth, or "pure yoga manifest." Continuing on Vivekananda's path, his goal was to prove that this truth was based on natural laws of science; therefore objective science was to be employed as "the handmaiden of spirituality and orthodox philosophy." ${ }^{22}$

One hundred years after Vivekananda, B.K.S. Iyengar, the founder of popular Iyengar Yoga, declared that modern life makes us lose our connection to our bodies, suggesting that we may regain it by "cellular enlightenment", in which we "relax the cells of the brain, and activate the cells of the vital organs and of the structural and skeletal body. Then intelligence

\footnotetext{
${ }^{20}$ Sointu and Woodhead, "Spirituality, Gender, and Expressive Selfhood"; Villamón et al., "Reflexive Modernization."

${ }^{21}$ Alter, Joseph S. "Yoga and Physical Education: Swami Kuvalayananda's Nationalist Project." Asian Medicine, Vol. 3: 20-36. 2007; De Michelis, "A Preliminary Survey of Modern Yoga Studies"; Van der Veer, "Global Breathing."

${ }_{22}$ Alter, Joseph S. Yoga in Modern India. The Body Between Science and Philosophy. Princeton, NJ: Princeton University Press. 2004, 83, 34-87.
} 
and consciousness may spread to each and every cell. ${ }^{23}$ The concept of 'cellular enlightenment' is ideologically an offshoot of Vivekananda's and Kuvalayananda's 'science of yoga,' trying to make yoga attractive to modern consumer culture by combining concepts of eastern spirituality and western science. Indeed, part of yoga's attraction is that it dispels the mind-body dualism. This approach appeals to the cosmopolitan exercise market, for it allows practicing non-defined 'eastern' spirituality without making any commitment to Hinduism, while the pretext of being 'scientific' or 'good for your health' disperses any misgivings regarding its ties to religion. Since yoga entered the US health market, Peter van der Veer claims, yoga-promoted Indian spirituality has become a lifestyle element and a market commodity. Today, there are nearly 16 million practitioners of yoga in the United States alone, and 4 million in Germany. ${ }^{24}$

Modern science, David Brown and Aspasia Leledaki argue, has the power to disembed yoga from its philosophical origins, because it can transform the understanding and practice of yoga into a primarily therapeutic form of exercise, thus erasing its ontological ground. ${ }^{25}$ Scientists have become interested on yoga and its health effects. Yet, there are countless research reports of yoga having positive effect on people's health. ${ }^{26}$ Although there are numerous studies on yoga that prove its efficacy, Joseph Alter points out, very little is known about how it works. In research conducted on asthma, for example, the diagnosis of the medical condition caused by respiratory function and allergic pathology is based on western science, but the cure is based on the yogic concept of prāna (the vital life force) and its manipulation. ${ }^{27}$

${ }^{23}$ In Lea, "Liberation or Limitation," 84.

${ }^{24}$ Van der Veer, "Global Breathing"; Hayes, Meg, and Sam Chase. "Prescribing Yoga." Primary Care, Vol. 37 no. 1 (2010): 31-47; Strauss, Sarah. Positioning Yoga: Balancing Acts Across Cultures. Oxford: Berg. 2005.

${ }^{25}$ Brown, David, and Aspasia Leledaki. "Eastern Movement Forms as Body-Self Transforming Cultural Practices in the West: Towards Sociological Perspective." Cultural Sociology, Vol. 4 no. 1 (2010): 123-154.

${ }^{26}$ See, for example, Brown and Gerbarg on yoga breathing and longevity (Brown, Richard, and Patricia Gerbarg. "Yoga Breathing, Meditation, and Longevity." Longevity, Regeneration, and Optimal Health: Ann. New York Academy of Sciences, 1172 (2009): 54-62.); Descilo, Teresa et al. "Effects of a Yoga Breath Intervention Alone and in Combination With an Exposure Therapy for Post-traumatic Stress Disorder and Depression in Survivors of the 2004 South-East Asia Tsunami." Acta Psychiatrica Scandinavica 12, no. 4 (2010): 289-30o; Tüzün et al. on yoga and postmenopausal osteoporosis (Tüzün, Şansin et al. "Yoga Might be an Alternative Training for the Quality of Life and Balance in Postmenopausal Osteoporosis." European Journal of Physical and Rehabilitation Medicine Vol. 46 no. 1 (2010): $69-72)$.

${ }_{27}$ Alter, Yoga in Modern India, 152. 


\section{Concentration}

While it was declared in The Lancet a bit more than a decade ago that doing scientific research on yoga that draws from its secret technology of mind sounded "wacky," today there are numerous studies in which scientists are interested in yoga's philosophical and religious aspects as well. For example, American neuroscientist Richard W. Maxwell discusses the neurobiology of chakras, the centers of concentrated metaphysical energy in the yogic system. Searching for their exact location and origin, he suggests that chakras could match with a locus of gap junctions in certain spots of human body, which arise during embryological development. ${ }^{28}$ Maxwell's study fits into the growing trend of combining the study of religion with neuroscience, in order to find a middle ground between these disciplines without the (apparent) reductionist attempt to explain religion away.

Sometimes neuroscientists like Maxwell lean toward the study of religion, but increasingly as well the scholars of religion try to bridge the gap to neuroscience. For example, Stephen Kaplan compares neuroscience with Advaita Vedānta and asparśa yoga in his attempt to explain the phenomenal boundaries between subject and object, while Ellen Goldberg notes that both cognitive science and yoga make forceful claims concerning the relationship between the body and the mind, especially on three points: they both reject mind-body dualism, they both hold strong views on the nature of consciousness, and they both discuss the role of the nervous and circulatory systems in religious experience. ${ }^{29}$ Many theories of cognitive science are challenging the Cartesian body-mind dichotomy; this new scientific paradigm presupposes interdependence, and utilizes such ideas as embodiment or the ontological rejection of dualism. Both of these ideas are in the very core of hatha yoga traditions, Goldberg notes, as practices like asanas (yoga postures), mantras (repetition of sacred sound), and pranayama (breathing meditation) are meant to lead towards "direct experience of one's own essential nondual nature." ${ }^{30}$

As the market for eastern spirituality opened, it was not only yoga that flourished, but a variety of Chinese spiritual exercises as well, such as

${ }^{28}$ Morris, Kelly. "Meditating on Yogic Science." The Lancet, Vol. 351 (1998): 1038; Maxwell, Richard W. "Neurobiology of Chakras and Prayer: The Physiological Foundation of Yoga Chakra Expression." Zygon Vol. 44 no. 4 (2009): 807-824.

${ }^{29}$ Kaplan, Stephen. "Grasping at Ontological Straws: Overcoming Reductionism in the Advaita Vedānta-Neuroscience Dialogue." Journal of the American Academy of Religion, Vol. 77 no. 2 (2009): 238-274.

$3^{\circ}$ Goldberg, Ellen. "Cognitive Science and Hathayoga." Zygon Vol. 40, no. 3 (2005): $620-621$. 
taijiquan. Qigong, which is commonly paired with taijiquan, also gained a transnational market. Chinese qigong includes several forms of exercise that, according to van der Veer, aim to "develop skills (gong) to use the vital energy ( $q i)$ present in the body to connect it to the natural world of which the body is a part." ${ }^{11}$ Although early communist China did not look favorably upon religious practices, qigong prospered because it was made part of a state-sanctioned medical science, thereby being removed from the realm of superstition into the domain of scientific clinics, as traditional techniques were transformed to meet the scientific standards of China. During the Cultural Revolution both qigong and taijiquan suffered, but as qigong was rediscovered in 1980 s and became popular again, it made its way to the global market. There it was sometimes introduced as purely a form of 'health orientation,' sometimes as 'spiritual healing. '32

Several studies have been conducted on taijiquan and qigong that verify their health effects. ${ }^{33}$ Neurobiology has also turned its investigating eye on these Chinese spiritual exercises, as the review by Tsang and Fung on neurobiological mechanisms of qigong exemplifies - they looked for neurobiological explanation for qigong's demonstrated anti-depressive effects. Alexandra Ryan predicts that due to the current shifts towards improved and provable efficiency in health and medicine, future scientific research will pay more attention to taijiquan. ${ }^{34}$

In karate, as in other budō, mind and body are treated as inseparable. Karate (or karate-d̄̄) is usually translated as 'the Way of the empty hand,' and it is one of the most popular and widely practiced Japanese martial arts in the world. The word empty has two meanings in karate: the

$3^{11}$ Van der Veer, Global Breathing, 316.

$3^{2}$ Van der Veer, Global Breathing; Valussi, Elena. “Women's Qigong in America.” Journal of Daoist Studies, Vol. 3 (2010): 187-201.

${ }_{33}$ See, for example, Song et al. on taijiquan and osteoarthritis (Song, Rhayun et al. "A Randomized Study of the Effects of T'ai Chi on Muscle Strength, Bone Mineral Density, and Fear of Falling in Women with Osteoarthritis." The Journal of Alternative and Complementary Medicine, 16 no. 3 (2010): 227-233); Wu and Ren on taijiquan and leg muscle activity (Wu, Ge, and Xiaolin Ren. "Speed Effect of Selected Tai Chi Chuan Movement on Leg Muscle Activity in Young and Old Practitioners. Clinical Biomechanics Vol. 24 no. 5 (2009): 415-421); Yan et al. on qigong and breast cancer (Yan, Xin et al. "External Qi of Yan Xin Qigong Induces Apoptosis and Inhibits Migration and Invasion of EstrogenIndependent Breast Cancer Cells Through Suppression of Akt/NF- $\varkappa B$ Signaling." Cellular Physiology \& Biochemistry Vol. 25 nos. 2/3 (2010): 263-270.).

34 Tsang, Hector, and Kelvin Fung. "A Review on Neurobiological and Psychological Mechanisms Underlying the Anti-depressive Effect of Qigong Exercise." Journal of Health Psychology, Vol. 13 no. 7 (2008): 857-863; Ryan, Globalization and the 'Internal Alchemy' in Chinese Martial Arts, 541. 
self-defense and combat techniques that do not require any weapons, and the 'emptiness' of Zen Buddhism. Karate is often said to have been modernized and thus transformed into a neo-tradition by Gishin Funakoshi (1870-1957), who altered the meaning of karate from 'Chinese hand' to 'empty hand' and added the suffix $d \bar{o}$, 'Way,' thus emphasizing the Zen spirituality of karate. ${ }^{35}$ Karate is both a system of codified fighting skills and as a Zen practice a way to enlightenment. Funakoshi stated that kara (empty) in karate means the "emptiness, void, that lies at the heart of all creation. ${ }^{{ }^{6} 6}$ Thus it is a physical exercise that actively creates space for non-dualism and tries to avoid the Cartesian mind-body dichotomy. ${ }^{37}$ This no-mind, or abandonment of self, dissolves mind-body dualism, as there is no mind to mind the dualism. Elsewhere Funakoshi explains that "just as it is the clear mirror that reflects without distortion, or the quiet valley that echoes a sound, so must one who would study karate-do purge himself of selfish and evil thoughts, for only with a clear mind and conscience can he understand that which he receives. ${ }^{38}$

The idea of emptiness in karate washes away both mind-body dichotomy and the division of 'body-mind-spirit' for in that state all categories are gone. This search for emptiness and dissolution of mind-body division appeals to cosmopolitan practitioners around the world. Yet the scientific quest of proving eastern physical exercises healthy or "good for the body and mind," which is so often important for the practitioners, in order to legitimize their art in front of their own eyes and others', ends up fortifying the division because often with validation through western science also comes the scientific paradigm that is bolstered by Cartesian dualism between mind and body. Western science carries a powerful legitimating force that may be used to validate a practitioner's self-cultivation and selfimprovement projects. ${ }^{39}$

Thus the fascination between science and these spiritual-physical exercises goes both ways. On the one hand, physicians and scientists such as neurobiologists are enthralled with both ontological questions regarding

\footnotetext{
35 Bar-On Cohen, Einat. "Kime and the Moving Body: Somatic Codes in Japanese Martial Arts." Body \& Society, Vol. 12, no. 4 (2006): 73-93.; Tan, "Constructing Martial Tradition"; Young, "Bowing to Your Enemies".

${ }^{36}$ Funakoshi, Gichin. Karate-Do: My Way of Life. Tokyo: Kodansha International, 1984, quoted in Young, "Bowing to Your Enemies".

37 Bar-On Cohen, "Kime and the Moving Body".

${ }^{8}$ Funakoshi, Gichin. Karate-do kyohan. Tokyo, New York, San Francisco: Kodansha International, 1973, 4, quoted in Tan, "Constructing Martial Tradition," 170.

39 Brown and Leledaki, "Eastern Movement Forms," 123-154.
} 
humanity and the potential physiological/health benefits of the exercises. On the other hand, practitioners, advocates, and some scholars doing research on these spiritual-physical exercises aim to prove the healthiness of the exercise, validating it in scientific terms, or looking for confirmation regarding mystic techniques from new disciplines like neurobiology.

\section{Spiritual-Physical Marketplace}

Recent research has helped clarify conceptions of spirituality in North America and Europe. For example, approximately 10-20 percent claim to be "spiritual not religious" and around 20-40 percent believe in "some sort of spirit or life force" or in a "god that is something within each person." ${ }^{\text {"40 }}$ This raises the question of whether the contemporary cultural emphasis on body and mind leaves more space for 'mind-body-spirit' practices than for those of 'mind-body-religiosity'; this question needs to be addressed in future research.

The spiritual marketplace has long recognized and thus catered to the demand of embodiment in modern spirituality. Consumerism, the idea that consumption equates with personal happiness, describes the tendency of people to identify strongly with products or services they consume. In relation to spirituality this means that the consumer culture of well-being exercises, holistic approaches to physical exercise and spiritual growth, and 'trademark' exercises, such as the internationally well-branded yoga schools like Iyengar Yoga, Ashtanga Yoga and Bikram Yoga, are now gaining ground in the spiritual-physical marketplace. Individualistic practitioners look for inner subjective experiences, as well as spiritual ones, in the physical exercises under discussion. Consumer culture creates a marketplace to 'pick and choose' those aspects of the practices and experiences that suit the individual at that particular time.

The marketplace of spiritual-physical practices reflects consumerism and the subjective turn in urban cultures worldwide. When these exercises are transformed to appeal to cosmopolitan taste, some spiritual or physical aspects remain, while some get omitted or altered. Exercises such as

\footnotetext{
${ }^{40}$ Sointu and Woodhead, "Spirituality, Gender, and Expressive Selfhood". The data drawing from RAMP (Pan-European study of religious and moral pluralism) and other surveys indicate, however, that using 'spiritual' as a concept in surveys and questionnaires is challenging for it may mean very different things to different people: for some it equals religiosity, for others it is dissimilar to it, and yet for others the two concepts cannot be set apart and distinguished that easily (Barker, "The Church Without God").
} 
yoga are sometimes taught and advertised without any reference to their cultural and religious context, in order to fit in the urban late-modern world, in which spiritual exercises that were originally deeply spiritual are often taken as a 'gym sport' or fitness technique. Yet cosmopolitan consumers have also found yoga so appealing because it offers "practical benefits in association with an ancient spiritual tradition," as Newcombe puts it. ${ }^{41}$ This discrepancy between 'fitness technique' and 'spiritual tradition' originates in two major trends in the market field of physical exercises: the trend of body management, toning, and efficiency, and the subjective turn with its search for inner experience, spirituality, and knowledge. Although these two perspectives may at first seem incompatible, they both arise from the context of consumer culture that celebrates certain kinds of individualism.

There are several spiritual-physical exercises that combine approaches of 'fitness technique' and 'spiritual tradition,' in addition to the abovediscussed yoga; taijiquan is a good example. The commonly made division between martial art taijiquan and health taijiquan is in fact mostly superficial, Ryan notes, for taijiquan in general emphasizes physical efficiency, spirituality and holistic orientation..$^{42}$ Taijiquan, like many other Asian martial arts, appeals to cosmopolitan practitioners because it combines, or rather fuses, both major trends in the global fitness market. Furthermore, its advocates attempt to legitimize its philosophy through western scientific validation. Teachers use the scientific evidence in taijiquan-associated qigong, for example, as Brown and Leledaki state, in order to appeal to a potential international cosmopolitan clientele for whom western science is an authoritative legitimating force. ${ }^{43}$ Thus the scientific approach to body and the fascination with neurobiological understandings of the body allow two tendencies to be brought together in the current exercise market. Through the scientific validation adopted by consumer culture the individual may legitimize the subjective and spiritual "but useful and efficient" practice.

The Japanese martial art judo also combines both approaches. Judo is based on the "principle of maximum efficiency in the use of physical and spiritual force," according to its founder Kanō. ${ }^{44}$ This tenet expresses the

\footnotetext{
${ }^{41}$ Newcombe, Suzanne. "Stretching for Health and Well-Being: Yoga and Women in Britain, 1960-1980. Asian Medicine, Vol. 3 (2007): 40.

${ }^{42}$ Ryan, "Globalization and the 'Internal Alchemy' in Chinese Martial Arts", 536.

43 Brown and Leledaki, "Eastern Movement Forms".

44 Villamón et al., "Reflexive Modernization".
} 
(seed for the) same combination of ideas that is now rocking the cosmopolitan exercise market—Kanō's remark shows that the ideas of maximum efficiency and spirituality encountered already in Japan, although it took a hundred more years to transform this into neurobiological fascination.

The modernization of spiritual-physical exercises like Japanese budō, in order to appeal to urban late-modern taste, is seeing some signs of attempting to counter-balance the scales, as the earlier example of western judokas longing for the re-spiritualization of judo shows. The postsecularization of the 'West' demands the embodied spirituality the exotic Asian exercises seem to offer. Yet the question remains whether the demand to put the ' $d \vec{o}$ ' back in judo is really an attempt to restore judo to its 'original' state, or if the objective is to make it fit the needs of the cosmopolitan individual who is longing for something spiritual in the aftermath of post-secularization and in the turn toward the subjective, but in her or his own terms.

The consumerist approach to spiritual-physical exercises may clash with their philosophical ground. In all the discussed exercises, the relationship between master and student is light years away from the one of seller and client. Where the master demands loyalty and maintains that the disciple will do the exercises and acquire knowledge when the master sees fit, in a consumer culture the client-practitioner demands information and experiences that fit one's needs at the time. There is a discrepancy in the spiritual-physical marketplace; consumerism, loyalty, and obedience do not go hand in hand. Spiritual-physical exercises, such as taijiquan, face new challenges as they gain ground in new cultural territories as a result of international expansion.

Like yoga and budō, taijiquan has undergone substantial transformations during the last century. It also has been touched by 'modernization', Ryan states, such as pedagogic innovations and the search for more efficient techniques and practices. ${ }^{45}$ The demand for efficacy in pedagogy and in technique is the current trend of the exercise market, which shows in a countless number of 'ten-step-programs,' videos, and guidebooks that promise mastery of an art by following the provided instructions. Therefore, the irony is not lost when an urban cosmopolitan individual seeks an alternative for the lifestyle of consumer culture and fitness techniques, Brown and Leledaki note, but ends up demanding individual and convenient experiences that cause the transformation of physical

\footnotetext{
${ }^{45}$ Ryan, Globalization and the 'Internal Alchemy' in Chinese Martial Arts, 540.
} 
exercises in the very same direction from which the individual wishes to be liberated. ${ }^{46}$

\section{Conclusion}

This chapter has introduced some perspectives on the multifaceted fabric of spiritual-physical exercises. Individuals choosing to practice these activities are often interested in new or alternative worldviews and belief systems, and some may become involved with the spiritual tradition connected to the exercise. There are also a (small) number of people who start to do, for example, yoga, Hasselle-Newcombe reminds us, because they are already involved with Hinduism. ${ }^{47}$ In most cases, however, the process goes the other way around. Students get involved in new exotic leisure activities and only later become interested in the underlying spiritual traditions. Enthusiasm and the length of time spent with the exercise are important factors, because one is more likely to learn about the profound philosophical matters the longer one spends with the other practitioners. Often in the beginner's class there is hardly any reference to the philosophical and spiritual principles that go hand in hand with the practice, or, if there is, it is represented in general philosophical terms without any reference to the actual spiritual dimensions of the exercise. The teachers do not want to alienate the beginners with the spiritual aspects before there is proper time to discuss things thoroughly. These aspects are considered to be a matter of private deliberation among urban late-modern individuals and thus not proper topics for the introductory classes, where the beginners only learn the first steps of the art. Yet eventually the time will come when these practitioners will have to negotiate, one way or the other, the spiritual principles regarding their belief systems.

Although the modernization and westernization of spiritual-physical exercises started more than a hundred years ago, the late modern urban world, suffused with consumerism and subjectivity, witnessed expansion of embodied spiritual practices in the cosmopolitan marketplace. While part of the attraction of these practices is the alternative take on body and spirituality, paradoxically, eastern practices often endeavor to legitimize the art in the eyes of cosmopolitan consumer culture by employing western scientific rhetoric. The fascination between science and the

46 Brown and Leledaki, "Eastern Movement Forms".

47 Hasselle-Newcombe, "Spirituality and 'Mystical Religion' in Contemporary Society”. 
spiritual-physical exercises is mutual, however; both scientists and advocates of the exercises are keen on finding proof of their health effects, with the advocates also trying to validate their art through a scientific aura. Thus they end up watering down the different understanding of humanity, body and spirituality, and emphasizing the Cartesian dualism of mind and body.

In modern yoga and budō the physical exercise is viewed as a way leading to deeper spiritual being and ultimately to enlightenment, but in cosmopolitan consumer culture this is often downplayed and these exercises are introduced as fitness techniques. Modern yoga, especially, has developed into teaching techniques and organized educational systems with certified teachers. Iyengar Yoga, Ashtanga Yoga and Bikram Yoga, which are among the most popular yoga schools in the world, are modern organizations with branches in dozens of countries, in all continents. Thus yoga and Asian martial arts like Japanese budō and Chinese taijiquan, in order to fit in the contemporary cosmopolitan world where profoundly spiritual practices are commonly viewed as fitness techniques, are sometimes taught and advertised without any indication as to the religious or cultural background. Urban late-modern individuals find the spiritual traditions of the 'East' appealing but they want to access them conveniently, through the existing mental and organizational framework of the cosmopolitan world. 


\title{
SLEEP DEPRIVATION: ASCETICISM, RELIGIOUS EXPERIENCE AND NEUROLOGICAL QUANDARIES ${ }^{1}$
}

\author{
Núria M. Farré-i-Barril
}

The purpose of this chapter is to analyze a rather puzzling and seemingly irrational ascetic practice, one that can be found in the most diverse religious traditions, but that so far has not received much attention from social scientists and religious scholars. I wish to look at sleep deprivation as a form of religious experience in the way it has been, and still is, practiced in different religions, with special reference to Christianity. My objective is to compare and contrast the cultural meanings associated with sleep deprivation in religious traditions with current neurological and neuropsychiatric researches on the effects of this condition on contemporary Western individuals, and to use this comparison / contrast to advance some hypotheses concerning the status of religion as a human experience and the ways we can approach this experience from both a cultural-historical and natural-scientific point of view.

Asceticism is normally associated with the deprivation of whatever is seen as vital, such as food, shelter, sex or, as we shall see in some detail in what follows, sleep. Behind all these practices there is usually, as a principal motive, the will to keep the body under control, to submit the body to the rule of the spirit and to bring the soul toward divinity. The explanations of sleep deprivation provided by religious traditions are very diverse, but most of them are related to notions of ascetic practice and corporal discipline as means of spiritual purification. In the majority of cases sleep deprivation is part of a set of ascetic activities equally focused on the principle of discipline and self-mortification, such as fasting, sexual abstinence and other kinds of physical exertions. What gives sleep deprivation a more specific significance, however, lies in its associated notions of wakefulness, alertness, as a desirable condition of the soul, in opposition to the passive state that is related to sleep. Furthermore, due consideration should also be given to hallucinatory states and more general cognitive dysfunctions and alterations brought forward by long term

${ }^{1}$ I would like to thank the editors of this book, Rebecca Norris and David Cave, for the insightful comments on an earlier draft of this chapter.

(C) NÚRIA M. FARRÉ-I-BARRIL, 2011 | DOI:10.1163/9789004225343_012

This is an open access chapter distributed under the terms of the CC BY-NC 4.0 license. 
sleep deprivation and, in particular, to the cultural-religious meanings attributed to them.

\section{Sleep Deprivation in World Religions}

I shall begin with a brief outlook at the ways in which some of the most important religious traditions have taken sleep deprivation as a form of asceticism. Information provided in this section will be very general since the extant literature for any one of the most important world religions is far too large and detailed to be included here. But for the purpose of this chapter a broad outlook will suffice.

Perhaps one of the oldest religious traditions where sleep deprivation figures prominently among its ascetic practices is Taoism. Taoists have always been suspicious of sleep because dreams cause a loss of control over oneself. Within the Quanzhen monastic order (twelfth century), such a fear induced ascetical practices of sleep deprivation and motivated collective meditation at night. In this context appeared, during the Jin and Yuan periods, the so-called "Poems of the Five Night Watches," which contain descriptions of night-time meditation. Like soldiers, Taoists must fight against sleep and keep their inner citadel free from intruders. The five watches are marked within the monasteries by drum strikes, hence they become a very sensitive reality for the religious communities. The main purpose of these watches seems to have been the fight against the temptation of dreams. Especially feared were erotic dreams and the possible nocturnal emissions that they might provoke. ${ }^{2}$

It was understood as well by several Taoist practitioners that a sleepless night would bring them nearer the Truth. The spirit (shen) should be the master of the organism, both during the day and at night. Together with erotic dreams, sleep was also supposed to make the person vulnerable to the attacks perpetrated by demons, devilish hallucinations and evil spirits (shuimo). Control over sleep should be obtained gradually, night after night. No fast results should be expected, and the need to sleep should disappear 'naturally.' The night should be devoted to meditation, and that seems to have been the main purpose of the Poems of the Five

\footnotetext{
${ }^{2}$ Cf. Stewart, Charles. "Erotic Dreams and Nightmares from Antiquity to the Present." Journal of the Royal Anthropological Institute 8, no. 2 (2002), 279-309; Farré-i-Barril, Núria M. "Interpenetrations of Nature and Morality: The Case of Nocturnal Seminal Emissions in Medieval Theological Thought." Quaderns-e 12, http://www.raco.cat/index.php/ QuadernseICA/article/view/124412/172392.
} 
Night Watches. ${ }^{3}$ For Taoists, therefore, sleep weakens the soul by making it vulnerable to evil supernatural attacks in the form of dreams. This association between malign attacks and dreams will be repeated in other religions as well. I shall propose later on a possible explanation for this nearly universal recurrence.

Another religious tradition where sleep deprivation has been widely practiced is Hinduism. The Punjabi word jagrātā means all-night vigil, usually to worship a deity with song and ritual. Such all-night vigils are found throughout the Indian subcontinent in a variety of religious contexts. In fact, the concept of waking or wakefulness, as in many religious traditions, is central to Hinduism. It could even be called a root metaphor for the Hindu religious experience-as well as other religious traditions such as Christianity and Buddhism, as we will see below. The state of enlightenment, for example, is often compared to being awake as opposed to being asleep or deluded. Deities who are active in the world, as opposed to being otiose, are said to be 'awake' ( jāgrit). Both in Hinduism and Buddhism, all-night vigils of one kind or another are seen as part of an intensive spiritual discipline. Gautama the Buddha (which means 'the awakened one') himself attained enlightenment during the night, and his meditative experiences during the several watches of the night are an important part of his spiritual biography. Besides being a denial of sleep, wakefulness itself is a positive quality, being associated with such attributes as wisdom and lucidity of mind. ${ }^{4}$

One question that arises is why enlightenment should be attained in this manner. A very similar relationship between wakefulness and wisdom or righteousness is seen in some parts of Islam. For instance, vigils and sleep deprivation were quite common in traditional Sufism. The origins of Sufism are in the days of the Prophet, in a group called ahl al-suffa, which means 'people of the bench,' for they had the habit of remaining in the mosque and spending days and nights in pious devotion. Sufism developed into a full-fledged mysticism in the late eighth and ninth centuries (CE), but the asceticism of the early Sufis remained an integral part of Sufi life. After the initial confession of sin and repentance from all deeds that would compromise the journey to God, the dervish's major preoccupation is with crushing one's passions, fighting, as the Sufis

\footnotetext{
3 Goossaert, Vincent. "Taoist Poems of the Five Night Watches." Études chinoises XIX, no. 1-2 (2000), 249-270.

4 Erndl, Kathleen M. "The Devi Jagrātā in Contemporary Panjabi Hinduism.” Journal of the American Academy of Religion 59, no. 2 (1991), 339-36o.
} 
say, against one's own soul. A time-honoured method of training the soul is to resist its desires through fasting and other forms of asceticism. The earliest Sufis practiced almost incredible feats of self-denial, shunning all forms of luxury and avoiding sleep (which was seen as a mark of 'heedlessness'), spending their nights in devotion and self-examination. A famous representative of early Sufism, Ibrāhīm ibn Adham (d. 776 or 790 ) said that one must embrace hardship, self-abasement, strenuous effort, sleeplessness, and poverty, ever anticipating death and judgment, in order to attain righteousness. ${ }^{5}$

In Judaism, on the other hand, the natural desire for sleep was disciplined in the service of the community. One of the Jews' self-imposed tasks was the observance of continuous worship. The Law was to be studied continually, day and night, as the members undertook in turns to perform this service. The implication is that sleep is a withdrawal from the service of God. Once again, it is as if sleep would push us away from the right path, which consequently can only be remedied by the state of wakefulness. The religious person needs to be a transformed human being, radically changed from within by his discipline. Such discipline was not so much directed at the control of self-indulgence as at the denial of satisfactions that would have been considered normal. Unrestrained sexual desire, the need for food and sleep, the need for emotional release, for material security, and for independence of thought, should be all strictly subjugated, as if the faithful were trying to be superhuman, destroying the power of all human drives that could become a source of sin. Traditionally for religious Jews, especially the Jews of Qumran, the purpose of those practices of self-mortification, sleep deprivation included, was not to destroy the body or the flesh but only the evil of the flesh. The practitioner is concerned with achieving the same effect in his own person as will occur at the final consummation of the age: the abolition of all wickedness. ${ }^{6}$

\section{Christianity}

Several recurrent themes that have been addressed so far can also be seen in the history of Christianity. According to religious historian Robert

\footnotetext{
${ }^{5}$ Hoffman, Valerie J. "Eating and Fasting for God in Sufi Tradition." Journal of the American Academy of Religion 63, no. 3 (1995), 465-484.

${ }^{6}$ Thiering, Barbara. "The Biblical Source of Qumran Asceticism." Journal of Biblical Literature 93, no. 3 (1974), 429-444.
} 
Kirschner, ${ }^{7}$ the Christian holy man shunned virtually everything needed by ordinary people. Symeon Stylites (fourth century), for instance, was reported neither to eat nor drink. It was said of a certain Elpidius that for 25 years he ate only on Sundays and Saturdays. He reached such a high degree of mortification and so wasted away his body that it was said, in a rather common metaphor, that the sun shone through his bones. Nor did the ascetic require the sleep of ordinary men. Anthony, the desert father, often passed the entire night without sleep. The Syrian stylites, if they slept at all, refused to lie down until extreme old age.

By the deliberate choice of such hardships, the Christian holy man sought to achieve apatheia, defined by Evagrius as the health of the soul, the very flower of ascesis. The proof of apatheia is had when the spirit begins to see its own light, when it remains in a state of tranquility in the presence of the images it has during sleep, and when it maintains its calm as it beholds the affairs of life. The purpose of apatheia is to arm the ascetic for the task of contending with demons. There are two peaceful states of the soul, Kirschner points out. The one arises from the natural basic energies of the soul and the other from the withdrawal of the demons. The monk who preserves intact the territory of the first state will perceive with greater sensitivity the raids made upon it by the demons. Were he to succeed, he can know for certain that he stands near the confines of apatheia, for his mind is strong enough to abolish thoughts inspired by the demons. ${ }^{8}$

Holy men were considered to be 'athletes of the spirit,' who seek to train their souls much as an athlete trains his body. Indeed the ancient monastic literature frequently refers to the holy man as 'the athlete of Christ.' In his celibacy, his identification with the poor, his sufferings, his confrontations with demons, his night-long prayer vigils and his miraculous healings, the Christian holy man conforms to a highly specific model. In the Vita Prima Graeca of Pachomius, the image of imitatio Christi is compelling. It is reported that after having said his prayers, he stayed up through the night, weeping and repeating the same prayers until daybreak. The holy man's example was followed in detail by careful imitation. For a long time, in fact for about fifteen years, whenever he (Pachomius) wanted to give his body rest and sleep after the weariness of a prayer vigil,

7 Kirschner, Robert. "The Vocation of Holiness in Late Antiquity." Vigiliae Christianae $3^{8}$ (1984), 105-124.

8 Kirschner, "The Volcation of Holiness", 111. 
he did it by sitting on something in the middle of the room, without leaning his back against the wall. When many of the fathers of those old days heard or rather saw this, they themselves tried the same or similar means of mortifying the flesh in order to enhance the salvation of their souls.

It should be emphasized that Christians conceived of asceticism as an effort to strengthen, and not to weaken, the body. Hence Athanasius, in his Life of Saint Anthony, one of the most influential books in the history of Christianity, described how the father of all monks underwent fasts and vigils in order to fortify his body for the fight against the demons, not to mortify it. ${ }^{9}$ The idea is a familiar one: sleep makes us vulnerable to evil assaults.

In Coptic and Copto-Arabic hagiographies we also find ascetics who imposed upon themselves techniques of the body commonly known as practices of self-mortification or self-denial. Among these practices we find chastity, the avoidance of washing and sleeplessness. Many of the Desert Fathers experimented with harsh ascetic regimens, severely limiting their sleep and their intake of food and drink. For example, Abba Arsenius claimed that "it is enough for a monk, if he is a real fighter, to sleep only one hour." ${ }^{{ }^{10}}$ Again, deprivation of sleep was the mark of the spiritual athlete. The goal of wakefulness and all-night vigils was to transcend the normal bodily processes and to achieve heightened consciousness; it helped the ascetic in his quest for a vision and permitted him to "see" the divinity. Why is it that we see the divinity while awake but we only see demons when we fall asleep? Can neurobiology enlighten us as to the reasons for this divergent interpretation? This is a very important point that will be further developed later."

As regards medieval ascetics, it was said of Abba Arsenius that at sunset, after the lighting of lamps at Saturday Vespers, he would stretch out his hand to heaven in prayer until the sun rose on Sunday morning to light up his face. Jacobus de Voragine tells us in the Golden Legend (thirteenth century) that Saint Ives passed most of the time without sleep both day and night. And when he had to, he slept on the earth, and instead of a

9 Stroumsa, Gedaliahu G. "Shaping the Person in Early Christian Thought." History of Religions 30, no. 1 (1990), 25-50. See also Bitton-Ashkelony, Brouria. "Demons and Prayers: Spiritual Exercises in the Monastic Community of Gaza in the Fifth and Sixth Centuries." Vigiliae Christianae 57, no. 2 (2003), 200-221.

${ }^{10}$ Naguib, Saphinaz-Amal. "The Martyr as Witness Coptic and Copto-Arabic Hagiographies as Mediators of Religious Memory." Numen 41, no. 3 (1994), 223-254.

${ }^{11}$ See Killgore et al. "Sleep Deprivation Reduces Perceived Emotional Intelligence and Constructive Thinking Skills." Sleep Medecine 9, no. 5 (2008), 517-526. 
pillow he laid under his head a book or a stone. Among the early monastic orders of the fourth to the eleventh centuries, regimens to tame the passions were employed that directly impinged upon the human physiological system. Permanent abstinence in cloistered convents under strict vows of poverty and obedience, and regulated periods of manual labor, fasting, sleep deprivation, hairshirts, and flagellation were defining characteristics of the holy life. Historian Peter Brown has stressed how important to the early monk's sense of spiritual purpose was a strict regimen of the body. "The material conditions of the monk's life," writes Brown, "were held capable of altering the consciousness itself." ${ }^{\prime \prime 2}$ Brown has made a very important point: it is not just a matter of strengthening the body and the soul but also of altering consciousness, i.e. making one see beyond the limits of one's natural world. I shall return to this.

Psychiatrist Jerome Kroll and historian Bernard Bachrach provide us with a more medically informed account. ${ }^{13}$ They point out that it is difficult to know for certain the degree of sleep deprivation undergone by monks during the Middle Ages. In all probability, monastic life entailed by itself a state of partial sleep deprivation, and this had psychological and physiological consequences. Among the most general effects we find general unrest (i.e. loss of sensation of well-being), irritability, somnolence during the day, and a depressive mood, together with perceptual distortions and illusions in which ordinary objects seem to take altered shapes and unusual characters. We should take into account that sleep deprivation never took place in isolation but it was part of a wide framework of ascetic practices which included different levels of self-injurious behavior and fasting. Kroll and Bachrach conclude that if illusions and perceptual distortions did occur, these would invariably take form and content from the religious symbols and expectations that provided the context of the holy person's life. By this they probably mean that those illusions would not have been experienced as pathological perceptual distortions but as symbolically encoded religious messages. In other words, there is a connection between religious experience and all sorts of 'distortions' and 'alterations' of consciousness consistent with a particular way of understanding the supernatural. It should be pointed out, however, that many

\footnotetext{
${ }^{12}$ Cited in Flynn, Maureen. "Taming Anger's Daughters: New Treatment for Emotional Problems in Renaissance Spain." Renaissance Quarterly 51, no. 3 (1998), 867.

${ }^{13}$ Kroll, Jerome and Bernard Bachrach. The Mystic Mind. The Psychology of Medieval Mystics and Ascetics. London: Routledge, 2005.
} 
of those reports are based on the subject's expectations and it is unclear whether they corresponded to actual experiences.

Another example was that of female mystics, such as Catharine of Siena, who remained in a small room mortifying her bodily instincts by limiting sleep to 30 minutes out of every 48 hours. She also fastened a metal chain tightly around her waist that pinched and broke into the skin. Under these conditions, she claimed to hear divine revelations and enjoy the intimate presence of God in her soul. ${ }^{14}$ Catherine's unusual behavior was extreme but was by no means unique among female ascetics of this time. Cutting off one's hair, self-flagellation, sleep deprivation, giving away food or possessions to the poor, sleeping on the floor (using a rock for a pillow) were among the most common self-mortifying exercises, and resulted in constant ideation about punishment and sinfulness, and an obsessional, insatiable craving for the Eucharist. ${ }^{15}$

In renaissance Spain, historian Maureen Flynn tells us, Peter of Alcantara spent 40 years of his life in obedience to a strict regimen of sleeping one and a half hours at night. ${ }^{16}$ Interestingly, two hundred years after his death, a Mexican woman was so moved after hearing about the saint's exploits that she privately vowed to develop her own ascetic exercises. Among several practices of self-mortification, she decided to refuse the temptations of sleep during the night by kneeling upon iron spikes designed for combing wool. Flynn concludes that such instances of self-inflicted torture were not unusual in the practice of traditional Christianity. The vitae of saints are filled with descriptions of ascetic practices that were performed in the belief that physical affliction would prepare the soul for God. The French mystic Simone Weil has written that "the extreme greatness of Christianity lies in the fact that it does not seek a supernatural remedy for suffering, but a supernatural use for suffering. ${ }^{{ }^{17}} \mathrm{It}$ is only through pain that the Christian wish for unity with God is fulfilled, as if the supernatural could only be experienced through some form of suffering.

Another interesting case of this culture of sleep deprivation is that of the eighteenth century Ukrainian monk Paisius Velichkovsky, for whom vigil is the fifth virtue that all monks should have as an objective. For him,

\footnotetext{
${ }^{14}$ Flynn, Maureen. “The Spiritual Uses of Pain in Spanish Mysticism." Journal of the American Academy of Religion 64, no. 2 (1996), 257.

${ }^{15}$ Lester, Rebecca J. “Embodied Voices: Women's Food Asceticism and the Negotiation of Identity." Ethnos 23, no. 2 (1995), 187-222.

${ }^{16}$ Flynn, "The Spiritual Uses of Pain", 257-258.

${ }^{17}$ Flynn, "The Spiritual Uses of Pain", 258.
} 
vigils cleanse the intellect of superficial thoughts and make it suitable for praying. Vigils practiced in moderation give joy to the heart. Sexual desire is produced in men by excess of food and, also, of sleep. When impure thoughts come to our minds, argued Velichkovsky, we should get rid of them by fasting and vigil. We need to fight against sleep for the sake of God's love. Sleep is for him a great calamity, since it is associated with the negligence of the intellect and places us, once again, as we have seen in so many other traditions, at the mercy of demons' attacks. Demons and passions distract the person from his main task, which is reunion with God and constant praying. When we close our eyes darkness falls upon our life and our intellect. Demons impose their rule by means of sleep and somnolence, and they keep the soul away from good works. All their efforts are devoted to distract the individual from his main duty, which is, Velichkovsky insists, incessant prayer. What could be the cause of our need to sleep?, he wonders. It is a "natural necessity," he concludes.

Velichkowsky would certainly agree with much of the perspective of modern neuroscience- as we will see in the next section, our body must have sleep, and that is not our choice, it is nature's way. But his point would be that our need to sleep might also originate in overindulgence, in the divagations of the intellect into undesirable paths or perhaps even in a fasting period that has lasted for too long. In any case, we need to fight against sleep with caution. In the same way as those who eat or drink too much will want more and more, those who sleep without limit will come to need even more sleep. They will spend their lives in the dark, with an indolent intellect, instead of practicing the virtues. Nature will ask very little of those who, on the contrary, get themselves into the habit of sleeping for a short time every night. In order to fight against sleep we need to practice four virtues: temperance, spiritual sobriety, prayer and remembering or thinking about death. We need to practice prolonged vigils in order to gradually reduce our need to sleep (the fifth virtue). Because excess of sleep and food weaken the body, vigils are needed to make the body strong. ${ }^{18}$

Finally, a remarkable and contemporary example of sleep deprivation for religious purposes is provided by the movement of Nocturnal Adoration, founded in France by the convert Jew Hermann Cohen in the mid nineteenth century. Tradition has it that he was so impressed when

\footnotetext{
${ }^{18}$ Aubry, Michel. Saint Païssius Vélichkovsky. Lausanne: Éditions l'Age d'Homme, 1992, $111-136$.
} 
he was exposed for the first time to the Blessed Sacrament that he refused to leave the church. There was a group of women in the church at that time who were allowed to remain there for the night, and Cohen asked the general vicar if he could do the same thing. The vicar told him that he could as long as he managed to gather a group of men for this purpose, and this is how the movement of nocturnal adoration was eventually born.

Cohen's organization did not emerge from scratch but it was in fact the continuation of an old tradition of night vigils. Nowadays there are branches of this movement in practically all continents, especially Europe and America. It is an association of believers who meet in groups once a month and take turns in order to worship God during the night as representatives of all humankind. During these night vigils they perform the liturgy of the hours and silent prayer. They see themselves as offering the sacrifice of sleep in order to fulfill during the night what they consider as the purpose of the Church and the aim of the Eucharist: to worship the Father with Christ and offer themselves to Him, as penitential victims, for the salvation of the world and the expiation of sins. They also see their night vigils as an emulation of Christ, who was supposed to pray at night, especially in his nocturnal and painful prayer at Gethsemane. ${ }^{19}$

\section{Suffering of the Soul and Privations of the Body}

As has already been suggested, sleep deprivation is not just an ideological or ideational option, such as praying every day or believing in God, it is a bodily practice that has repercussions upon the subject's neurophysiological condition. After reviewing the role of sleep deprivation in various religious traditions, we will explore now the nature of those neurophysiological repercussions. Specifically, I shall be looking at the effects that long term sleep deprivation might have on cognition and mental and bodily health in general, and see to what extent these scientific or naturalistic perspectives could be 'matched' with cultural meanings furnished by the religious traditions we have just reviewed.

The first thing that catches our attention is that on the whole (and despite the existence of some contradictory evidence) there is seemingly a sharp contrast between the positive moral significance that those religions

\footnotetext{
19 See www.nocturnaladoration.org.
} 
give to sleep deprivation and the very negative and harmful effects that sleep deprivation is supposed to have on both mental and bodily health of the individual, according to neurological research. ${ }^{20}$

Contemporary western society furnishes several examples of sleep deprivation which happen to be quite far from the ideas of ascetic practitioners. Long working hours, nocturnal celebrations and leisure, and notorious torture methods well-known in dictatorial regimes all over the world can be taken as contemporary instances of sleep deprivation devoid of any religious significance. Still, some of these have been taken as objects of medical scrutiny in order to investigate the effects of such a situation on the individual's health. There are several studies that have explored the neurophysiological implications of sleep deprivation. In these studies we normally come across the distinction between partial deprivation (restricted amounts of sleep per night), short-term deprivation (one to four nights without sleep) and long term deprivation (five or more nights of sleep deprivation). ${ }^{21}$ Even though some authors have defended the beneficial consequences of this practice, especially if it appears associated with fasting, ${ }^{22}$ the majority of medical researches emphasize the very damaging effects of lack of sleep.

Different types of sleep deprivation have different physiological and psychological effects upon mood and upon perceptual, cognitive, and motor functions. Total sleep deprivation, for instance, leads to the deterioration of motor tasks, resistance to exercise, the loss of peripheral visual information, and misrepresentation of visual stimuli and visual and tactile hallucinations (peak incidence of perceptual distortions is between midnight and four in the morning). There is also a significant relapse in cognitive performance (logical reasoning, mental addition, visual search and word memory tasks), plus mood changes such as irritability and depression, decreased vigor, occasional feeling of persecution and, in general, decreased ability to direct and maintain attention. ${ }^{23} \operatorname{In} 1982$ more than one

\footnotetext{
${ }^{20}$ Needless to say, the interpretation of this contrast is based in a particular worldview that does not necessarily correspond to that of the practitioners, i.e. those who deprive themselves of sleep for religious reasons do not necessarily see any 'harm' in that, but, as we have seen, they might consider it as a way of strengthening both the soul and the body. See Norris, Rebecca S. "The Paradox of Healing Pain." Religion 39, no. 1 (2009), 22-33.

${ }^{21}$ Siegel, Jerome. The Neural Control of Sleep and Waking. New York: Springer, 2002, 135.

${ }^{22}$ Bushnell, William C. "Psycophysiological and Comparative Analysis Ascetico-Meditational Discipline: Toward a New Theory of Asceticism." In Asceticism, edited by Vincent L. Wimbush and Richard Valantis, 553-575. New York: Oxford University Press, 1995.

${ }^{23}$ Kroll, The Mystic Mind, 72-82.
} 
million men and women from 30 to 102 years of age were surveyed about the number of hours they slept per night. In 1988 it was found that those who slept 7 hours had the highest rate of survival and those who reported more than 8.5 hours of sleep or less than 3.5 or 4 to 5 hours of sleep had an increased risk of dying younger. ${ }^{24}$ Our current knowledge that extensive sleep deprivation may be harmful is based on the dramatic findings of Allan Rechtschaffen at the University of Chicago. ${ }^{25} \mathrm{He}$ and collaborators deprived rats of sleep and reported their findings in a series of papers. The effects of sleep deprivation were dramatic and extreme. Within two to three weeks every sleep-deprived rat died. The results of this and other research suggests that sleep-deprived individuals are more susceptible to disease and that already-sick patients who are sleep deprived would become even more ill and their recovery would be impaired.

Other studies have shown that there is a direct relationship between sleep deprivation and a reduced pain threshold. ${ }^{26}$ Sleep deprivation and sleep disruption increase pain sensitivity and vulnerability to pain. A vicious circle is established, then, with sleep disorder and chronic pain maintaining and augmenting each other as a result. Similarly, it has also been shown that sleep deprivation is associated with a mild increase in preoccupation with health-related issues and concerns about bodily function. ${ }^{27}$ There is also a significant worsening of mood, including anxiety and depression. For depressive complaints, according to neuroscientists Khan-Greene et al. ${ }^{28}$ sleep deprivation was associated with a mild increase in depressive thinking, including feelings of powerlessness, inadequacy, worthlessness, failure, and self-doubt, as well as affective symptoms of sadness, loss of interest in pleasurable activities, and decreased life satisfaction. Finally, sleep deprivation is associated with a subtle elevation of interpersonal mistrust and hostility toward others, as measured by the paranoia scale. ${ }^{29}$ Khan-Greene et al also argue that while there is no evidence of heightened vigilance or guardedness following sleep loss, there

${ }^{24}$ Siegel, The Neural Control, 136-143.

${ }_{25}$ Rechtschaffen et al. "Sleep Deprivation in the Rat. Conceptual Issues." Sleep 12, no. 1 (1989), 1-4.

${ }^{26}$ Kundermann et al. "Sleep Deprivation Affects Thermal Pain Thresholds but Not Somatosensory Thresholds in Healthy Volunteers." Psychosomatic Medicine 66 (2004), 932-937.

${ }^{27}$ Killgore et al. "Sleep Deprivation", 517-526.

${ }^{28}$ Kahn-Greene et al. "The Effects of Sleep Deprivation on Symptoms of Psychopathology in Healthy Adults." Sleep Medicine 8 (2007), 215-221.

${ }^{29}$ Epstein, Seymour. Manual for the Constructive Thinking Inventory. Amherst, M.A.: University of Massachussets, 1993 . 
are increased feelings of persecution and perception of unfair treatment by others, including greater resentment, sensitivity to perceived insults/ slights, and projection of blame onto others.

Researchers have also found that sleep loss produces temporary changes in cerebral metabolism, cognition, emotion, and behavior consistent with mild prefrontal lobe dysfunction. Relative to baseline, sleep deprivation has been associated with lower scores on Total EQ (decreased global emotional intelligence), intrapersonal functioning (reduced self-regard, assertiveness, sense of independence, and self-actualization), interpersonal functioning (reduced empathy toward others and quality of interpersonal relationships), stress management skills (reduced impulse control and difficulty with delay of gratification), and behavioral coping (reduced positive thinking and action orientation). What psychiatrists call 'Esoteric Thinking', by which they refer to greater reliance on formal superstitions and magical thinking processes, is increased under conditions of sleep deprivation. Participants in some experiments endorsed higher scores on Esoteric Thinking after sleep loss, a pattern that includes beliefs in magical, strange, and scientifically unfounded phenomena, such as paranormal occurrences and superstitions. The observed decreases in behavioral coping and concomitant increases in "maladaptive esoteric thinking" suggest that sleep deprivation may produce a general decline in adaptive cognition and effective coping, both of which are critical features of emotional intelligence. ${ }^{30}$ Clearly, what in psychiatrists' language corresponds to "maladaptive esoteric thinking" or "beliefs in magical, strange and scientifically unfounded phenomena" looks strikingly similar to the ascetic practices we saw earlier.

Much the same can be said as regards the higher incidences of hallucinations in subjects deprived of sleep. Perceptual distortions and illusions in which ordinary objects seem to take on altered shapes and unusual characteristics are frequent occurrences. An interesting case is that of a 75 year-old retired clergyman with a ten year history of idiopathic Parkinson's disease studied by Jason Warren. The patient experienced visions of deceased relatives and parishioners. But interestingly, he was not distressed by the visions and commented that such experiences were natural in a person with his occupational background..$^{31}$ Again, the

$3^{30}$ Killgore et al. "Sleep Deprivation....", 517-526.

${ }^{31}$ Knight et al. "The Cultural Context of Visual Hallucinations." Postgraduate Medical Journal 84, no. 988 (2008), 103-105. 
clergyman was interpreting in a religious language what for others were instances of neuropathological hallucinations.

\section{Beyond the Nature/Culture Divide}

The contrast between religious perspectives and those of medical researches could hardly be more pronounced. One interesting area of inquiry is why these two worldviews appear so different from each other and what can we learn about the nature of religious experience and the supernatural from this stark contrast. Biologists of different persuasions have consistently argued that humans appear to be the only living organism capable of defying their instinctual drives. In Dawkins's words: "We have the power to defy the selfish genes of our birth. ${ }^{{ }^{2} 2}$ But there has to be a reason for it. What could possibly be the reason for sleep deprivation as practiced by individuals belonging to such a variegated spectrum of religious and cultural traditions? From Taoism to Judaism, from the ancient Desert Fathers to the modern followers of the Nocturnal Adoration movement, not to mention the numerous tribal religions where different forms of sleep deprivation also fulfill important ritual functions (e.g. among the Navajo), all seem to find some sort of deep significance in this ostensibly unnatural practice. But is sleep deprivation an 'unnatural' practice or could there be some underlying organic function behind its biological uselessness?

Some sociobiologists would be tempted to argue that nothing in humans, not even the most apparently bizarre cultural institution, can escape the determination of our evolved innate predispositions. Hence behind what at first sight appears to be contrary to an individual's wellbeing, so the argument runs, there is likely to be some hidden biological function that promotes his or her biological fitness-in other words, we cannot escape from our genes. But the information provided so far does not seem to support this conclusion, for sleep deprivation does not seem to fulfill any biological function nor improve in any way one's reproductive fitness but quite the reverse, as overwhelming medical evidence has

\footnotetext{
${ }^{32}$ Dawkins, Richard. The Selfish Gene. Oxford: Oxford University Press, 1989, 200. Cf. Gould, Stephen Jay. "Natural Selection and the Human Brain: Darwin vs. Wallace." In The Panda's Thumb. More Reflections on Natural History, 47-58. New York: Norton, 1980; Lewontin et al. Not in Our Genes: Biology, Ideology and Human Nature. New York: Pantheon Books, 1985; Richerson, Peter J. and Robert Boyd. Not by Genes Alone. How Culture Transformed Human Evolution. Chicago: University of Chicago Press, 2005.
} 
come to demonstrate. The key to a proper understanding of the practice of sleep deprivation seems to lay not in hidden harmonies between nature and culture (whatever we mean by these highly contested concepts), but in their frontal opposition. Sleep deprivation is a case in point of 'rebellion against our genes'.

A cursory view on the two perspectives, let us call them the 'culturalreligious' and the 'medical-scientific,' shows how incongruent they are in their conclusions. The highest virtues of sleep deprivation, according to religious interpreters, are turned into severe pathologies and dysfunctions, according to medical scientists. Anti-relativists would contend that these discrepancies can be simply accounted for in terms of the 'ignorance' and 'fanaticism' commonly associated with religious traditions, particularly ancient religious traditions, as contrasted with the 'enlightenment' provided by modern scientific thinking. Relativists, by contrast, would take this as an instance of diversity of world-views. Both religious doctrines and scientific theories would be seen, from this perspective, as more or less arbitrary cultural constructs, with no epistemological privilege given to any of them. ${ }^{33}$ But one cannot equate the epistemology of religion with that of science; religion is interpretative while science is explanative.

My position, however, is that none of these divergent schools of thought (relativism and anti-relativism or rationalism) can take us to a proper explanation of the practice of sleep deprivation as a total human experience. ${ }^{34}$ The bodies of ascetics belonging to the most diverse cultural traditions and historical periods were, in all probability, very similar to the bodies of those who have undergone medical experiments in contemporary settings, no matter how diverse their respective 'cultural minds' happen to be. So in all likelihood, results of contemporary neurological and neuropsychiatric researches are equally valuable to understand much of the neurobiology behind the experience of those, culturally and historically remote, religious practitioners.

On the other hand, a careful reading of the results of contemporary medical researches shows that their analyses and diagnoses include culturally

\footnotetext{
${ }^{33}$ See the debates between rationalists and relativists in Hollis, Martin and Stephen Lukes. Rationality and Relativism. Oxford: Blackwell, 1982.

${ }^{34}$ Marcel Mauss defined the gift as a "total social fact" to refer to its capacity to articulate a whole system of social relationships. I am using the phrase "total human experience" to equally emphasize the capacity of sleep deprivation to relate multiple levels of human experience: physical, psychological, spiritual, etc. See Mauss, Marcel. The Gift. London: Routledge, 1990.
} 
informed and somewhat contentious evaluations concerning the nature of mental health. Notions such as 'esoteric' or 'magical thinking,' 'formal superstitions,' 'beliefs in scientifically unfounded phenomena,' or the very concept of 'adaptive cognition,' are used quite often in psychiatric papers that deal with the effects of sleep deprivation, as we have seen, and yet these concepts are all complex and controversial from a social-scientific and anthropological point of view. What we see in these medical-scientific accounts are not only descriptions of neurological conditions and symptoms, but also a great deal of interpretative evaluation concerning the 'normal' or 'abnormal / pathological' quality of those conditions and symptoms. And it is in these interpretative evaluations that divergences between the cultural-religious and the medical-scientific perspectives are more salient. The reason behind these discrepancies has to do with the status of the supernatural in current scientific thinking.

The 'supernatural' means, quite literally, what lies beyond or above nature, that is, what cannot be understood as resulting from the ordinary unfolding of natural phenomena. The relationship of sleep deprivation with some sort of experience or 'perception' of a supernatural realm is well established in many religious traditions. By contrast, the status of the supernatural in contemporary science is simply that of the unthinkable, nothing can be beyond nature. Anthropologists have recently argued that the supernatural should be seen as a cross-cultural concept that refers to unintelligible and counterintuitive experiences that directly challenge ordinary day-to-day cognition. ${ }^{35}$

The question then becomes, how do humans have access to these experiences if, by definition, they lay beyond ordinary cognition? So-called altered states of consciousness have been traditionally one of those ways, precisely because those are states in which ordinary cognition is drastically transformed. Apart from being a practice of self-mortification, similar in this sense to other ascetic practices such as fasting or chastity, sleep deprivation was seen by many of its religious practitioners as a form of communication with the deities. Hallucinatory experiences during wakefulness were freely interpreted as divine visions, in contrast to dreams, which were instead seen as machinations of demons and evil spirits. Similarly, the cognitive dysfunctions that loss of sleep is likely to engender, such as loss of memory, are seen by religious interpreters as signs of

35 Boyer, Pascal. Religion Explained. The Evolutionary Origins of Religious Thought. New York: Basic Books, 2001. 
intellectual cleansing and mental purification that bring the ascetic closer to the divine condition.

Furthermore, different interpretations of hallucinatory experiences originating in dreams and sleep deprivation point to one key aspect of this sort of ascetic practice, and that is the notion of agency. ${ }^{36}$ Both types of hallucinations, those originating in dreams and in sleep deprivation, might have a very similar neurophysiological origin, even though they stem from apparently contradictory activities. But it is in the contradictory nature of these activities, sleep and lack of sleep, that their conflicting cultural meanings find their justification. Whereas dreams in sleep are seen as resulting from a passive state of the soul, hence its vulnerability to the demons' attacks and the phantasmagoric images that they produce in the sleeping individual's mind, hallucinations in sleep deprivation originate in a very active will to remain awake. Consequently, those hallucinations will be seen as divinely inspired.

Sleep deprivation can be seen as a clear instance of what anthropologist Harvey Whitehouse ${ }^{37}$ has labeled as the "imagistic mode of religiosity," wherein the transmission of maximally counterintuitive religious messages takes place through images (i.e. bodily experiences) rather than texts (i.e. propositional meanings). Whitehouse's argument is that religion does not fulfill any biologically adaptive function; the human brain has not been specifically designed by natural selection to have religious experiences (i.e. to grasp a supernatural reality). Hence ordinary perception turns out to be clearly insufficient to achieve this without the assistance of some culturally constructed mental prosthesis, as it were-some cultural means by which everyday reality can be transformed into something extraordinary. According to Whitehouse's theorization, ritual fulfills this function. There is certainly nothing 'natural' or 'adaptive' (in biological terms) in the ascetic practice of sleep deprivation, precisely because its purpose is no other than breaking the limits of our natural world.

To understand how those natural limits can be culturally exceeded we have to look at the complex articulation between 'nature' and 'culture' from a comprehensive or all-inclusive point of view, i.e. a perspective that takes into consideration both what we know about the nature of our bodies and the cultural systems that have dealt with that nature throughout

\footnotetext{
${ }_{3}^{6}$ Asad, Talal. "Agency and Pain: An Exploration.” Culture and Religion 1 (2002), 29-6o.

37 Whitehouse, Harvey. Modes of Religiosity. A Cognitive Theory of Religious Transmission. Waltnut Creek: Altamira Press, 2004.
} 
history (by reconfiguring it, reorganizing it, and maybe contradicting it). Hence my purpose in this chapter has not been merely to confront the religious-cultural language of belief with the natural-scientific perspective provided by neurological and neuropsychiatric researches, but to explore ways in which both viewpoints can be seen as mutually enlightening. In so doing, I did not want to uncover a possible natural-scientific explanation for a puzzling cultural custom, but merely to ascertain the need for a comprehensive approach to a total human experience and its irreducibly bio-cultural nature.

Sleep deprivation can be seen as a form of intentional suffering, ${ }^{38}$ such as that endured by neophytes in initiation rituals, which is necessary to stretch ordinary cognition beyond its natural limits. In my view, both the natural-scientific and the cultural-historical approaches are needed to fully understand and appreciate the intensity of these type of experiences, for only a biomedical perspective can tell us which are those natural limits and how they can be modified, and only a cultural-historical approach can inform us of the reasons that may lead individuals modify or overcome those limits.

${ }^{38}$ See Norris, "The Paradox of Healing Pain." 


\title{
SIKHISM AND MENTAL ILLNESS: NEGOTIATING COMPETING CULTURES
}

\author{
Jagbir Jhutti-Johal
}

\section{"Only God's Name can Heal a Diseased Body and Mind"}

A mental disorder or mental illness may be described as an affliction of the brain resulting in abnormal psychological or behavioral patterns. Examples are schizophrenia, depression, bipolar disorder and disorders due to drug abuse. The understanding of mental disorders has changed over time and its diagnosis and treatment still varies across different cultures and societies. While there is no single accepted cause of mental illness in the medical world, studies of the significant causes and processes involved in the development of mental illness have found that there are physical (biologic in nature), social, environmental, and psychological causes for mental illness. This means that a number of treatments currently exist for mental illness including medication, counseling, psychotherapy and self help within the medical arena.

The scientific view, which is based on observable evidence of the biological processes in the brain, forms the platform on which all the major healthcare providers around the world build their treatments. From this perspective mental illness is a symptom of a chemical imbalance, brain disease or due to some psychological trauma. Science, at present, equates mental phenomena with neuronal activity and does not view the mind or consciousness as anything different from the other functions of the brain, like vision and memory. This scientific, and evidence-based, approach to medicine has posed many questions and challenges for religious people, and has forced them to re-address their own 'religious' explanations for mental illness and the type of help they require to treat the condition.

Sikhs in general have not engaged in the science/religion debate, particularly evident in the field of healthcare in which there has not been much

\footnotetext{
${ }^{1}$ Guru Granth Sahib: 1146. Translations of quotes from the Guru Granth Sahib are arrived at through a consultation of Gopal Singh's translation (Sri Guru Granth Sahib: English Version. 4 vols. Chandigarh, India: World Sikh University Press, 1978) and an authorised copy of the Guru Granth Sahib in Gurmukhi language. This was done to ensure that the translation was as accurate as possible.
} 
substantive engagement with the scientific orientation and understanding of mental illness. Explanations for mental illness have historically been the moral province of religion, which views it as a physical manifestation of a disease of the soul and spirit, rather than physical illness of the brain, to be cured by meditation and leading a God-centred life. In some instances, such illnesses were viewed has having value because the process of recovery, through prayer and meditation, is spiritually transforming. This is in contrast to the current Western biomedical perspective, where mental illness is understood to be the result of a biological imbalance, and does not have value, but instead needs to be alleviated.

Although considerable research has been conducted on mental illness as a whole, the experiences of Sikhs in this area have been largely neglected. This chapter will fill a gap that is present in the literature on the Sikh religion and culture, which tends to ignore or treat as secondary scientific or medical issues by moving the debate about the role of religion and biomedicine in Sikh life from the periphery to the centre of contemporary Sikh thought. This chapter will investigate firstly the core components of Sikh explanatory models of mental illness. Taking concepts from the Sikh holy text, the Guru Granth Sahib, this section will look at the concept of the human body and mind in Sikhism and then consider the apparent causes of mental illnesses. While the particular focus will be on theological perspectives around mental disorders, this chapter will put the traditional Sikh understanding of mental illness into a modern context.

Additionally, it will examine the complexity of contemporary Sikh views on mental illness and the negotiation of competing cultures: secular western biomedicine and Sikh religious treatment. Up to now there has been a paucity of research done on attitudes about depression and mental illness amongst the Sikh community. This is because Sikhs are apprehensive and reluctant to talk about such issues with their doctor or community leaders due to the social taboo and stigma surrounding depression or mental illnesses, which has traditionally led to a self-denial status quo within the community. Using ethnographic research conducted as part of this study this chapter will discuss how Sikhs today negotiate the medi$\mathrm{cal} /$ religious divide when they or a family member have a mental illness, and also how traditional Sikh views can be understood in relation to biomedical perspectives and vice versa. What will become clear is that Sikhs suffering from mental illness in Britain resort to a number of treatments, religious, cultural, and pharmacological, and some may even use them concurrently, even if they do not always understand how they work. 


\section{Sikh Scripture: The Mind and Body}

The central message of Sikhism is contained within the Guru Granth Sahib, the holy book of the Sikhs. It is a voluminous body of work (1430 pages) containing the collected works of the Sikh Gurus and sacred writings of other Indian (Muslim and Hindu) saints. It is regarded as the final and 'eternal Guru', a title conferred to it by the tenth and final living Guru of the Sikhs, Gobind Singh. Its authority is beyond question for Sikhs, who view it as the repository of God's word transmitted through his messengers, the Gurus. ${ }^{2}$ It is with this scripture therefore that we begin our study of attitudes towards mental illness.

The Sikh religious psychiatric theory is rooted in the Sikh concept of the body and the soul. For Sikhs, the human body is a vessel that contains the divine spark of God within it. This spark is referred to as the atma or soul. While it may appear to have an individual nature, the ultimate aim of the soul is to lose this individual identity and merge with its original source, God. To achieve this 'loss of self' and union with God the soul experiences a journey through a cycle of birth, death and re-birth, as determined by its karma, of many life-forms. Sikh scriptures state that a soul may traverse 8.4 million life forms before union with God. The human body is the ultimate life-form and the only form from which a soul may obtain this release from the countless reincarnations it undergoes. In other words, the soul needs the human experience as part of the karmic process to achieve liberation and union with its source. Human beings therefore sit at the top of the ladder of creation and are believed to be blessed with a level of consciousness and self-awareness to enable them to realize God. ${ }^{3}$

It is the soul that is responsible for the mind and intellect and through the body the soul experiences the trials, tribulations and pleasures of human existence. ${ }^{4}$

Throughout the Guru Granth Sahib there is a focus on the mind and the human body because the body houses the soul that leaves the body at death to unite with God. Thus, the body and soul are essential in the

${ }^{2}$ McLeod, William Hew, Sikhism. London: Penguin, 1997; McLeod, William Hew, The Sikhs. History, Religion and Society. New York: Columbia University Press, 1989; Takhar, Opinderjit Kaur. 2005. Sikh Identity: An exploration of groups among Sikhs. Aldershot, UK: Ashgate Publishing Limited, 2005, 10.

3 Cole, W.O. The Guru in Sikhism. London: Darton, Longman \& Todd, 1982, 42; and McLeod, The Sikhs. History, Religion and Society.

${ }^{4}$ Jhutti-Johal, Jagbir, Sikhism Today. London: Continuum Press, 2011. 
process of transmigration. This ultimate goal of uniting with God means that the health of the mind and soul play an essential role in one's overall health. The body is the interface between the physical, materialistic dimension which is ephemeral in nature, and the spiritual, God-realised realm which is eternal and the ultimate truth. The body is endowed with nine outward facing physical 'doors' or openings, into the outer world, i.e. eyes, ears, nose, mouth etc., and a tenth inward-facing non-physical portal. The abode of God can be found within the body through this tenth portal, which is known as the gateway to enlightenment. Sikhs believe that the mind and soul are prevented from opening the tenth door and realizing God by the shackles of haumai, which can loosely be defined as ego or self-centredness. ${ }^{5}$ The Guru Granth Sahib refers to haumai as a deadly or chronic disease which pollutes and sullies the mind, and as we shall see later, for Sikhs, this is the ultimate cause of mental illness. Ego is the basis of the five 'evils' enumerated in the Sikh scriptures, namely, kam (lust or desire), krodh (anger), lobh (greed/covetousness), moh (attachment), and ahankar (pride) which lead the individual to maya, a state of self-delusion and worldly attachment. ${ }^{6}$

It is the challenge of all humans to conquer their haumai and subdue the five 'evils' to realize the ultimate truth. ${ }^{7}$ The process of choosing virtuous living against a life where individuals are attached to worldly possessions is complex and played out within the mind: The mind is action; mind is righteousness, mind is born of five elements'. ${ }^{8}$ Through haumai the mind can either become a constructive or a destructive force, and can either lead one into a blissful state where focus is on God, or it can cause despair through a focus on haumai and the five vices. For example, a materialistic attitude and an attachment to worldly possessions (maya) affects social relationships and interactions with others in a negative way, and ultimately leads to heightened stress levels, negative thoughts, low self-esteem and a feeling of emptiness for the individual. This state of being may be described as a spiritual imbalance and for some people this imbalance is so significant that it acts as a trigger for mental illness and depression.

\footnotetext{
${ }^{5}$ Nesbitt, Eleanor. "The Body in Sikh Tradition". In Religion and the Body, edited by S. Coakley. Cambridge: Cambridge University Press, 2000.

${ }^{6}$ Guru Granth Sahib, 600.

7 Singh, Avtar. Ethics of the Sikhs. Patiala: Punjabi University Publication Department, 1996: $55^{-83}$.

${ }^{8}$ Guru Granth Sahib, 415.
} 


\section{Conquering Mental Illness}

Conquering mental illness for Sikhs has traditionally been viewed in the context of addressing the spiritual imbalances arising due to haumai and past actions (karma) of the individual. Sikhs have therefore looked for guidance on how to progress spiritually and thereby alleviate pain and suffering from their eternal Guru, the Guru Granth Sahib. The Guru Granth Sahib sets out repeatedly what one should do to achieve this goal and the ultimate goal of union with God. It describes five realms or levels (khands) of spiritual experience as one traverses the path to union with God. ${ }^{9}$ The final level, the realm of Truth, leads to the realization of the ultimate Truth and complete harmony with God. These khands represent a kind of evolutionary process in the development of consciousness and the steps to removing the shackles of haumai and hence disease.

The Gurus argued that nam simran (spiritual meditation on God's name) is the key to stabilizing the mind. ${ }^{10}$ Nam simran is the axis on which the teachings of the Guru Granth Sahib revolve and holds the key to this spiritual progress. It is a process of constantly remembering mentally and uttering by tongue the name of God which is meant to align individual consciousness with universal consciousness and uproot the five evils of the mind and body."

The practice of nam simran can be enhanced by keeping the company of saints, and meditating within a congregation of other religious people (sadh sangat). Worship in such a group is important because it is thought to help an individual concentrate and it focuses the mind on nam simran:

The world is drunk, engrossed in sexual desire, anger and egotism. Seek the sanctuary of the saints, and fall at their feet; your suffering and darkness shall be removed. ${ }^{12}$

Thus, Sikhs believe that those who recognise that God resides in each individual and recite God's name through the regular practice of nam simran will find peace and live a life free of anxiety, stress and not suffering. The Divine Name therefore became the medicine for all ailments, and it

\footnotetext{
9 Jhutti-Johal, Jagbir and Sukhvinder Singh Johal, "The Sikh Grand Narrative", In Palliative Care amongst South Asians, editors A.R. Gatrad et al., London: Quay Books, 2005, 83-94.

${ }_{10}$ McLeod, The Sikhs: History, Religion and Society, and Takhar, Sikh Identity, 8.

"Jhutti-Johal, Sikhism Today, 8.

${ }_{12}$ Guru Granth Sahib, 51.
} 
has the capacity to remove all mental, physical or spiritual pain and suffering: "Hearing the true bani dispels sufferings, ailments and agonies". ${ }^{13}$

While nam simran is the key to conquering haumai, performing good deeds and practicing humility is also essential to cleanse and stabilize the mind. This is enshrined in a Sikh concept called sewa, which may be defined as selfless service. Sewa, is voluntary service to others in the community but also humanity at large, and is a core value which has been institutionalised in Sikh worship and religious life, and is essential for liberation. Through sewa one attempts to replace the five vices with truth, compassion, love, humility and contentment, engendering positive thoughts and thereby improving one's health.

A Sikh focused on the principles of nam simran and sewa becomes less self-centred (manmukh) and more God-centred (gurmukh), because the body, mind and spirit is God-focused, allowing the individual to live in harmony with God's will (hukam), and ensuring that a Sikh does not suffer from mental anguish. ${ }^{14}$

Another key concept that appears in Sikhism when depression or mental illness is discussed is Chardi Kala, which is a mental state of eternal optimism and bliss. It reflects the ideal and cherished mental state of a true Sikh which is based on unflinching dedication to and contentment with the Will of God, even if at times one suffers severe hardship. Chardi Kala literally translates as an 'ascending energy' within the mind and body. Sikhs, through their daily prayers and sermons, are instructed to strive to accept and practice this state of being at all times. Tales of optimism and joy in the face of adversity from Sikh history reinforce this point.

The above practices, but particularly nam simran, have provided Sikhs with a framework to transform their mental state and physical well-being. This has traditionally been in the context of a purely religious view of the world. Today neuroscience provides us with a viewpoint that is based on observational evidence rather than subjective experience and therefore mirrors an evidence-based reality. Sikhs now face the challenge of considering the transformative power of nam simran within this neuroscientificbased view of reality.

There is no body of literature that has been produced as yet by Sikhs to present a 'scientific' view of the benefits of nam simran, but a number of speakers on media outlets (Sikh TV channels in India and in the UK, and

${ }_{13}$ Guru Granth Sahib, 922.

${ }^{14}$ Jhutti-Johal, Sikhism Today, 57-63. 
internet contributors) have begun to tentatively take steps in this direction. For example, the transmission of past talks by speakers like the late Yogi Bhajan, the founder of the $3_{3 \mathrm{HO}}{ }^{15}$ attempts to present the practice of nam simran and in particular, Kundalini yoga, in a methodological, quasiscientific way.

Practitioners of Kundalini Yoga argue that it is the Yoga of Awareness, of Chardi Kala, and that its approach is holistic. It aims to balance humans' physical, spiritual, psychological, and social aspects. The emphasis is on purification, to enable a higher level of consciousness, and self-realization, ${ }^{16}$ rather than the treatment of illness or disease. Whilst the Gora Sikhs acknowledge that the internal process of merging with the Infinite that is described in the Guru Granth Sahib is identical to universal principles of union with God that was taught by the ancient yogis, they stress that a Sikh does not do yoga to "earn" his or her liberation, but does it to prepare the body to bring the nam into it. ${ }^{17}$

Gora Sikhs are increasingly using a quasi-scientific mindset when describing what processes occur in the brain and body when doing nam simran and yoga. They talk about how exercises, like breathing exercises (long deep breathing), calms the mind, balances the emotions, and harmonizes the body, mind, and spirit. They also argue that Kundalini Yoga balances the glandular system, strengthens the nervous system, and enables the individual to harness the energy of the mind and of the emotions so that they can be in control of themselves, rather than being controlled by their thoughts and feelings. Through these exercises the body is meant to be transformed and the mind cleared to concentrate on the Divine Name. ${ }^{18}$

To date Kundalini Yoga has not generally been practised by mainstream Punjabi Sikhs. However, because Kundalini yoga is being presented in a quasi-scientific way (e.g. energy centres, or chakras, rising like a serpent

${ }^{15}{ }_{3} \mathrm{HO}$ refers to the Sikh Dharma of the Western Hemisphere or 'Happy, Healthy, Holy' $(3 \mathrm{HO})$ movement which originated in the United States. Its followers are mainly located in New Mexico and Southern California. Members of $3 \mathrm{HO}$ are referred to as Gora Sikhs because they are white western converts (mainly from America) to Sikhism.

${ }^{16}$ Engebretson, Joan. "Culture and complementary therapies". Nursing \& Midwifery, 8, (2002): 177-184.

${ }^{17}$ Dusenbery, Verne, A. "Punjabi Sikhs and Gora Sikhs: Conflicting Assertion of Sikh Identity in North America." In Sikh History and Religion in the Twentieth Century, editors Joseph T, O'Connell et al., Toronto: Centre for South Asian Studies, University of Toronto, $1988,334-55$.

${ }_{18}$ " $3 \mathrm{HO}$ Foundation: healthy, happy, holy organization - a global community of living yoga." http://www.3ho.org/kundalini-yoga/kundalini-yoga-yb/ 
through the body), and because this ancient 'religious' practice is being presented as a secular exercise to improve body toning and to calm the mind, Punjabi Sikhs are increasingly recognizing that incorporating nonconventional forms of physical exercise such as yoga into their daily routines would be beneficial to their health.

One young Sikh woman, a doctor herself, described how she has learnt to deal with stress through yoga:

My stress is experienced in response to a range of physical, occupational and emotional stimuli. If you can control the stress then a sense of wellbeing is maintained, but if the stress goes beyond normal limits, physical and mental symptoms such as anxiety and depression can appear. I know that I can use psychological and pharmacological treatments to treat the stress, but I don't. I turn to yoga, and because of my Sikh heritage I am very interested in the Kundalini Yoga. I don't use it for the spiritual aspect. I use it for its health benefits. It is clear from my own patients that Yoga is becoming an increasingly popular therapy amongst Sikhs to maintain wellness and assist with the management of a range of health complaints.

One elderly gentleman described his use of yoga:

I suffer from anxiety. My doctor prescribed tablets and regular exercise. I don't have time to do the exercise they suggest so I use my time when I am praying to do exercise through yoga. On the TV there are a lot of channels which show religious priests/teachers teaching yoga exercises to be used in meditation. For me yoga aids the body to work in harmony with the mind. It is a natural way of improving one's health. It is flexible, and it can be adapted to suit all needs, regardless of age, physical ability and background.

He continued:

Yoga is a popular aid in improving physical and health. This is basically the common goal of people who practice Yoga. They want to ease their back pain, find a method to ease stress, or learn ways to deal with their health problems. The spiritual aspect of yoga doesn't exist today.

Thus, a spiritual practice has gained immense popularity as a form of recreational activity contributing to the idea of healthy living amongst Punjabi Sikhs in India and in the West.

\section{The Study}

Having highlighted Sikh religious perspectives on mental illness, this chapter now examines the complexity of contemporary Sikh views on the topic. I explore how modern Sikhs negotiate the medical/religious divide 
when they or a family member have a mental illness, and how traditional Sikh views can be understood in relation to biomedical perspectives and vice versa.

I interviewed a sample of Sikhs in the UK, both men and women. The interviews took place in 2009 and early 2010, and the approach taken was in the form of a semi-structured, interview-based questionnaire; however, some questions were open-ended. Face-to face interviews were conducted among fifty Sikhs in the UK in Punjabi and English. The sample consisted of thirty women and twenty men: eleven women were between the ages of fifty and eighty; nineteen were between the ages of eighteen and fifty. All the older women (fifty to eighty years old) had received little or no formal education when they were growing up. The women between the ages of eighteen and fifty had received some form of education. Most of the young women had gone to the university or had plans to attend. Three of the older women were baptised (ages sixty-three, sixty-five and seventy-one); none of the young women were baptised. ${ }^{19}$ Twenty men were interviewed between the ages of twenty-six and seventy-five. Five men were baptized: (ages thirty-three, fifty-six, sixty-two, sixty-five, and sixty-nine).

Prior to the interviews respondents were given a brief about the study, together with a sample of the questions in advance. The ten interview questions were not made too academic or lengthy. Respondents were promised absolute confidentiality. This was essential if respondents were to offer an accurate assessment of the situation, as they understood it.

All interviews were one-to-one and lasted a minimum of one to two hours. Notes were taken for all interviews, and only twelve interviews were recorded and then transcribed. All twelve of these respondents were young Sikhs. Although the issue of confidentiality and anonymity was stressed, some refused to be interviewed and expressed concern that if interviews were recorded then other people might get to hear them and that their problems or opinions would become public knowledge. ${ }^{20}$

Analysing transcripts from the open-ended, semi-structured interviews, demonstrated different ways of thinking and perceiving mental illness,

${ }_{19}$ This refers to the Sikh baptism/initiation ceremony, Amrit Sanchar. This was introduced by the tenth Guru, Guru Gobind Singh.

${ }^{20}$ This methodology has been employed by me in other ethnographic studies that I have done on the Sikh community. For example, Jhutti-Johal, Jagbir, "The role of women in their religious institutions: a contemporary account", in Sikhism and Women: History, Texts and Experience, edited by Doris Jakobsch, India: Oxford University Press, 2010, 234-251. 
especially themes or depictions of mental health issues in Sikh scripture and culture.

\section{Cultural View of Mental Illness}

The previous section discussed the Sikh theological perspective on mental illness from the interpretation of Sikh scripture. However, it is clear that a religious interpretation or diagnosis of mental health problems is not prominent amongst Sikhs today. Instead, after analysing transcripts from the open-ended semi-structured interviews it was evident that there were different ways of thinking about, perceiving, and treating mental illness. For example, culture plays an important part in how Sikhs understand mental health. Evidence shows that many older Sikhs understand mental health problems outside of the biomedical, and sometimes even outside of the religious model. Sikhs are instructed by their religious scriptures and codes of conduct (Rehat Maryada) ${ }^{21}$ not to believe in witchcraft and spirit possession, ${ }^{22}$ but it is common for them to locate the causes of mental health problems in a social context or other external factors (black magic, evil eye, and spirit possession), which are in opposition to Sikh religious teachings. Thus, it is clear that one cannot simply look at Sikh religious teachings to ascertain the perceptions and views of mental illness amongst the Sikh community; one must also examine mental illness through a cultural lens to get the overall picture.

It is human instinct to try to rationalise illness and misfortunewhether it involves seeking a medical, scientific, religious or spiritual explanation. For example, depression, which can manifest itself in the form of a lack of motivation accompanied by feelings of weakness and anxiety, in Indian religious traditions has been attributed to the evil eye,' najjar, rather than a chemical imbalance in the brain. The concept of spirit possession (djinn ${ }^{23}$ - can be spelt jinn) is prevalent amongst the Muslim Community, and the concept of the 'evil eye/stare ${ }^{24}$ is prevalent

\footnotetext{
${ }^{21}$ SGPC, Sikh Rehat Maryada. Amritsar: Shiromani Gurdwara Parbandhak Committee, 1950.

${ }^{22}$ McLeod, Sikhism; Cole, William Owen. and Piara Singh Sambhi, The Sikhs: Their Beliefs and Practices. London: Routledge and Kegan Paul, 1985.

${ }_{23}^{2}$ Djinn in Islam is a spirit, lower than the angels, which is able to appear in human and animal forms, and has power over people.

${ }_{24}$ 'Evil eye/stare' is a gaze or stare that can cause sickness and bad luck.
} 
amongst Indian communities. ${ }^{25}$ In Hinduism the terms 'possession' and 'bad spirits' are used interchangeably. There is a considerable body of literature on beliefs and practices surrounding witchcraft, spirit possession, and exorcism in countries such as Africa, India and Pakistan. This work emanates from anthropologists such as Edward Evans-Pritchard ${ }^{26}$ and Jean La Fontaine ${ }^{27}$ sociologists such as Emma Cohen ${ }^{28}$ and theologians such as Bettina Schmidt and Lucy Huskinson. ${ }^{29}$

However, with regard to the Sikh community not much has been written on this topic, even though it is evident that these concepts do play an important role in Sikh society. Although Sikhs are a distinct religious group, they share many cultural customs and practices with other South Asian communities, even though many of these practices may appear to contradict formal Sikh teachings. Cultural concepts, i.e. black magic and the 'evil eye' amongst the Sikh community, do affect the understanding of mental illness. It is these cultural concepts, rather than religious concepts, which help Sikhs to define and understand mental illness. For example, the onset of mental illnesses is attributed to spirit /demon possession, the casting of an 'evil eye' (najjar), or black magic ( jadu tona). Rituals to exorcise bad spirits or remove the effects these 'cause' are often used, and as a result medical help is often considered as a last resort. The ethnographic study carried out for this chapter highlighted that najjar is a concern of Sikhs across all socio-economic groups.

\section{How Sikhs Negotiate the Medical Divide}

There are both commonalities and differences in religious practices between members of the same religious tradition and culture. While Sikhs share many attributes, such as a common physical and geographic homeland and a history, it is clear that the Sikh community is highly diverse and is made up of different regional, caste, and socio-economic identities. As a result, Sikhs follow a variety of traditions. What is also clear from

\footnotetext{
${ }^{25}$ Morgan, Diane. Essential Islam: A Comprehensive Guide to Belief and Practice, Greenwood Press Publishing, 2009.

${ }^{26}$ Evans Pritchards, E.E. Witchcraft, Oracles and Magic among the Azande. Oxford: Oxford University Press, 1976.

${ }^{27}$ Fontaine, Jean La. The Devil's Children. Surry, UK: Ashgate Publishing Limited, 2009.

${ }^{28}$ Cohen, Emma. The Mind Possessed: The Cognition of Spirit Possession in an AfroBrazilian Religious Tradition. Oxford: Oxford University Press, 2007.

${ }^{29}$ Schmidt, Bettina E and Lucy Huskinson (eds), Spirit Possession and Trance New Interdisciplinary Perspectives. London: Continuum Press, 2010.
} 
the research is that when people become afflicted with mental illness they resort to a number of belief systems to explain and treat their illness even though this may mean that they move away from their core religious beliefs. For example, a person who has a strong religious identity may understand mental health issues in a different way from someone with a euro-centric medical understanding. Sikhs, young and old, male and female, construe the notion of health and well-being in different ways, depending on a number of factors: gender, age, location, economic and caste status, educational background, and degree of religious belief. Out of the above factors, gender and age play a very important role in the utilization of biomedical or traditional religious and cultural care.

Sikh men generally do not admit to suffering from any form of mental illness due to stigmatisation and cultural expectations that men should cope with illness and adversity. Since the cultural expectation for men does not allow mental ill health, Sikh men are more familiar with the biomedical system, which provides a scientific explanation, while Sikh women, especially elderly Sikh women (generally of low educational status), are more likely to see their religious leaders for spiritual guidance rather than doctors because they attribute such states to cultural or religious factors, such as bad karma, najjar, or the evil eye.

While mental health professionals agree that mental illness is the result of chemical imbalances in the brain, older Sikhs are not familiar with such research. For the older Sikhs their explanatory model is derived from their cultural and religious realities, in a sense an informal theory. For example, within the Sikh language there is no word for mental illness. Instead, elders use metaphors and proverbs, such as 'my heart is heavy' or 'my head is heavy' to describe mental illnesses. Older Sikhs do not see the origins of illness from a biomedical point of view, but rather as a result of external factors, i.e. supernatural elements, such as spirits, or the participation of people with the supernatural through such avenues as the 'evil eye', or karma.

The majority of Sikhs believe in the transmigration of souls and so many older Sikhs have conceptualised mental illness as a punishment from a previous life. Sikhs understand mental illness as being based on God's will, which means a belief in reincarnation and karma. Reincarnation means the soul undergoes various births and rebirths, in both human and nonhuman forms, dependent on past actions. True liberation from this cycle of reincarnation, a goal for all Sikhs, can only occur once the soul has progressed into human form. The process of reincarnation is determined by karma. Sikhs believe that all beings are subject to the universal law of 
karma, which states that any situation they face in life arises due to past actions of the individual. The corollary of this is that any affliction that one faces is, in part, due to the karma of that individual and should be accepted as such. Sikhs, therefore, should not complain about their plight, but must strive to change their karma through the power of nam simran. ${ }^{30}$ Thus, there is a belief that mental illness is due to a patient's karma and that suffering is due to past actions: this was reflected in my respondents' responses. One elderly woman said "My daughter had a breakdown. They said it was a mental breakdown. I don't understand when everyone tries to explain what has happened. All I think of is that her karam are bad. She must have done something bad in her past life."

As a consequence, karma introduces the notion that the person with an illness has committed bad deeds in a previous life and is now reaping the consequences, which raises concerns about stigma, prejudice, and discrimination by the host community, but most importantly by the ill person's own community. The potency of the stigma attached to mental illness is one reason why some Sikhs who would benefit from mental health services elect not to seek or adequately participate in treatment. The stigma can impede treatment and well-being.

Although mental illness is directly linked to the pernicious effects of haumai, one must ask why such an illness affects certain people and not others, even though they may appear to be equally religious. From a scientific viewpoint, although the exact cause of most mental illnesses is not known, research suggests that many of the conditions associated with it are caused by a combination of biological (such as an abnormal balance of neurotransmitters, genetic hereditary, infections, brain injury etc.), psychological (such as psychological trauma), and environmental (such as poverty) factors..$^{31}$

A traditional Sikh viewpoint would argue that an individual is not being 'religious' enough in observing the tenets of the faith. From the study it was clear that elders, especially the men who are baptised and are priests, view such illnesses as problems arising out of an individual's spiritual and religious imbalance, which is a consequence of living contrary to the teachings in the Guru Granth Sahib. For example, most elders believe in karma or that someone who is ill is preoccupied by haumai or engaged

\footnotetext{
${ }^{\circ}$ Jhutti-Johal, Sikhism Today, 8.

${ }^{31}$ Barlow, David H. and Vincent Mark Durand, Abnormal Psychology (Fifth Ed.) Canada: Cengage Learning, 2009.
} 
in the five vices, and that they, the male elders, in their capacity as religious teachers, could provide assistance in interpreting Scripture and tradition, and guide individuals back towards God, and in turn better health. One elder described how "[m]ental illness and suffering is a result of our karma, or our weak relationship with God. We don't see it biologically."

Thus, they are familiar with religious teachings that talk about the mind and inner turmoil. Most will side with their scriptural understanding, which is that mental illness is not caused by God, but is caused by problems in the relationship between the individual and God, and they will turn to religious teachings to deal with problems that others would define as medical. For example, a seventy year old man told me how when he was diagnosed with depression he was given several medicines which he never used. "When coming back from the doctor I said to myself 'You are the Guru's Sikh; you do not need medicine'. I put the medicine away and turned to nam because the Guru Granth Sahib says nam is the treatment for all ailments."

Thus, religious coping is utilized by older Sikhs who viewed adversity as a test from God, and had a strong belief that it was solvable and surmountable through assistance from an omnipotent and caring God. Older Sikhs tend to regard God's help, grace and blessing, and mercy, as well as unfailing love as being powerful enough for them to withstand any adversities they face in their lives. Since mental illness was seen as a sign of not being sufficiently religious, many older Sikhs believed that this could be alleviated with religious prayers and so called spiritual rituals, even, paradoxically, for the non-religious.

While faith and spirituality played an important role in treatment, healing and recovery for older respondents (sixty-three percent), many older Sikhs have also turned to relaxation methods, such as meditation and yoga, for example Kundalini, to bring their emotions and body into balance. The elders also stressed that their religion gave them a greater social support network, which results in better psychological and physical health.

When it came to biomedical treatment it was clear that some of the older Sikhs, particularly women, did not trust scientific treatments because they viewed doctors suspiciously — as people who dismissed religious values and failed to recognize religious values as a genuine source of healing. However, there were other older Sikhs, mainly men, who were overly accepting of medical treatments. This may have been because the men were better acculturated into the host community than the women, or because they viewed doctors as figures of authority. 
It is important to note that in instances where biomedical treatment has been utilized by older Sikhs it is clear that sometimes there is a lack of compliance. The research indicated that those who comply with medical treatment that is offered were acculturated and had integrated aspects of both 'British' and Sikh lifestyles. Those who did not comply with the medical treatment were mainly the elderly, particularly the women, because they were less acculturated into British society and held onto traditional values and beliefs.

Thus, through the process of acculturation it is clear that the understanding of illness resonates differently amongst different generations of Sikhs. Advances in neuroscience, in particular, over the past twenty years or so have begun to explain many aspects that previously Sikhs discussed in the realm of religion. Seemingly intractable subjects such as the mindbody issue are now being progressed in a scientific manner and consequently the great philosophical divide here is disappearing, especially for the young Sikhs.

Although religious and cultural understandings of healthcare were brought by Sikh parents when they migrated to the UK from India, it is clear that they have been 'adapted' and 'altered' by young Sikhs who are wedged between two cultures, western and eastern (Punjabi). As a result of acculturation and education young Sikhs view illness and its causes in a very different way from their parents and grandparents. For example, there is a greater sense of understanding and acceptance of problems such as mental health and depression. As rationalists, young Sikhs have adopted a perception of depression and mental illness that is similar to that of their British peers, and as a result the young are no longer accepting the religious or cultural model of disease and illness. This may also be because they are not that familiar with scripture and religious teachings. One respondent said:

My sister is a schizophrenic. She can be horrible and mean due to the illness. This is caused by something malfunctioning in the brain, like the temporal or frontal lobes. When these become damaged through disease a person starts to hear voices and do strange things. This behaviour has got nothing to do with spirits or God and punishment. It's all due to neurological imbalances.

Instead of focusing on karma and religious orientation young Sikhs assigned more importance to the stresses of modern life in contributing to their physical and emotional well being. They referred to illnesses as being a result of job and family stress. They discussed how the body deals with external stresses and how at some point these stresses manifest in the form of mental illness and emotional distress. Younger Sikhs also felt 
that in some instances, religion and culture were in themselves the root causes of mental illness due to their rigidity, authoritarianism, and expectations, especially with reference to women.

Evidently, religious beliefs and diagnoses are being questioned critically in a modern context. Young Sikhs think in terms of biology and medicine. Education and knowledge has meant that the younger generation are 'skilful navigators' ${ }^{32}$ who are able to make use of the western medical system for diagnosis and treatment. For example, the responses of young educated women reflected how increasing 'westernisation,' economic liberation, and educational opportunities have inevitably led women to question 'traditional' and 'religious' interpretations.

Young Sikh women view illness, whether mental or physical, as a medical problem resulting from a malfunction of a component of the mind or body, rather than a religious problem resulting from not fulfilling religious duties, such as not praying enough or not going to the Gurdwara. The majority of young women were happy to accept a medical diagnosis and comply with medical treatment because western medicine and treatment allows young Sikhs to be treated as independent entities whose needs, rights, and opinions are respected. This is unlike traditional religious treatments where the individual is treated as part of the collective family unit. However, it was interesting to see that some of the young Sikhs also recognised that this independence or individual interests may trigger illnesses in some instances, due to the lack of identity and support given by the extended family. This minority assigned importance to the extended family, unlike others in their peer group who valued western ideals of isolation and independence from the extended family and turned to their elders and religious authorities for help. Under the guidance of their elders, this latter group assigned a religious or cultural cause for certain illnesses. One young Sikh stated that:

I like the independence that I have got, however, it might sound silly but I also like being part of the extended family and social group. This does have some advantages at the psychological level. My family and community provide protection and security, a feeling of belonging and identity, as well as support when I am ill. The only problem with this is that my identity and desires sometimes get lost.

${ }^{32}$ Ballard, R. “The Emergence of Desh Pardesh," In Desh Pardesh: The South Asian Presence in Britain, edited by R. Ballard. London: Hurst \& Co. Publishers Ltd, 1994. 
The majority of young Sikh men also dismiss the idea that mental illnesses are due to religious factors, namely lack of religious observance. They stressed that when someone is ill they are not going to calmly turn to God and accept that the illness is due to his will (hukam), but rather individuals are more likely to feel anger and resentment towards God for their suffering. As a result of such thinking the overriding view from this group is that the religious community should not attempt to deal with such problems and that treatment and diagnosis should be left to medical professionals.

Accordingly, while first generation Sikhs understand and treat mental illness through a religious and cultural idiom, second and third generation Sikhs, who have grown up in the west, utilize biomedical treatments. Although the younger generation may accept that the biomedical system can successfully address the physical symptoms, they do acknowledge that the medical community may not recognise or understand the cultural or religious factors that may have contributed to certain mental health illnesses. For example, sometimes family, which can act as a buffer against illness and depression, may be the cause. There was also evidence that they were happy to use religious and cultural treatment methods if needs arose as long as medical treatment was not abandoned. Thus, common patterns of treatment pathways can be observed for all generations, but the order may change depending on age and acculturation. For example, young Sikhs who are not baptised will probably observe the following order: family/friends, then a general practitioner or psychiatrist. Older Sikhs and those who are baptised would consult these various resources in a different order.

Despite the variation in opinions about the origins and treatment of mental illness, what is clear is that although Sikhs do use alternative treatments such as yoga to supplement their medical treatment most Sikhs do not mention this to their doctor, even if they would welcome an opportunity to discuss alternative remedies with their doctors. There is little information about why this is so. However, it can be assumed that reasons for non-disclosure included anticipating the doctor's disinterest or negative response, and the perception that the religious and cultural treatments used were irrelevant to the biomedical treatment course. However, while Sikhs may not discuss alternative treatments with their doctor, most are likely to discuss details of their biomedical treatments with their religious priest or faith healer. 


\section{Conclusion}

It is evident that there is not much scientific engagement with Sikhism specifically. As a result, in this chapter I have addressed the issue of mental illness from a general religious/scriptural perspective. This chapter has attempted to explain the Sikh view of mental illness from a cultural and religious perspective, but also highlights the complexity of contemporary Sikh views on the issue, and the negotiation of competing cultures by different generations.

It is evident that traditionally, religion and culture were understood to play an important role in the origin of illness, and the religious community offered remedies which cannot be scientifically and biomedically justified, but met their followers' need to 'make sense' of illness in terms of their religious/cultural model of illness. For example, from Sikh religious teachings it is evident that the human mind and body are entities that allow the atma or divine soul to experience worldly existence and provide it with an opportunity to finally break the cycle of birth, death and re-birth and realise the ultimate truth that is God. As a result, there is a focus within the Guru Granth Sahib on the health of the soul and the mind. An affliction of the mind occurs when haumai takes such a strong stranglehold that the mind and body become disconnected with the divine soul they house. This can be caused by a morbid attachment to wealth and worldly possession (maya) or any of the five vices described in the Guru Granth Sahib. Also, operation of the laws of karma, mean that development of mental illness or any affliction of the body and mind are largely pre-determined by past actions. In order to improve mental health one must attempt to conquer haumai and control the five vices by having perfect faith in God and seeking God through spiritual meditation (nam simran) and the performing of good deeds. ${ }^{33}$ This would be the first step to recovery advocated by a religious Sikh model of mental health counselling.

Advances in neuroscience, however, have meant that many of the traditional belief systems of religion and culture, including those concerning the causes and treatment of mental illness, have been construed as belonging to a 'dark' and unenlightened age. In fact, a number of recent studies have sought to explain the belief in religion and spiritual experiences

${ }^{33}$ Jhutti-Johal, Sikhism Today, 57-63. 
in terms of evolutionary adaptive cognitive functions ${ }^{34}$ and increased variability in serotonin $5-\mathrm{HT}_{1 \mathrm{~A}}$ receptor density. ${ }^{35}$ The evidence-based approach of modern medicine and the biomedical model of mental illness, which dominates western health care, means that religious communities, including Sikhs, are having to interpret and adapt their teachings to a modern age, but also re-appraise attitudes and beliefs about mental illness. My ethnographic study shows that this is happening in iterative steps amongst the Sikh community, generally from one generation to the next.

This ethnographic research ${ }^{36}$ highlights how the majority of older Sikhs, especially if the onset of mental illness is later in life, assign some form of religious cause to mental illness, be it karma or a punishment from God, or a lack of religious orientation, or the social/cultural belief of spirit possession. Many older Sikhs fall back on cultural, mainly non-Sikh, beliefs and practices to understand and deal with mental health problems. Causes ascribed to include spirit possession, black magic, the 'evil eye,' or punishment for bad deeds in a previous life, and Sikhs frequently turn to priests, Sikh and non-Sikh (Muslim pirs and Hindu pundits) for help.

The influence of religious and spiritual beliefs on coping strategies and on attitudes to conventional treatments is evident amongst older Sikhs. However, among the young Sikhs who have been educated in the West, have become acculturated into western society, and have adopted the views of science, traditional beliefs are far less prevalent and rigid since they tend to define all illness as a purely medical problem. They view mental illness as being caused by biological, psychological or environmental factors. Young educated Sikhs are more likely to shun cultural and, to a lesser extent, religious beliefs on mental illness and seek professional, medical help as a first resort. The mind is approached as a mind-body entity, and as a result mental illness is defined as a medical problem to be treated through an evaluation, medical treatment and follow-up of a patient through professional counselling in a biomedical context, rather than talk therapy with a religious priest. While they may be quick to argue

\footnotetext{
${ }^{34}$ Kapogiannis, Dimitrios, Aron K. Barbey, Michael Su, Giovanna Zamboni, Frank Krueger, Jordan Grafman. "Cognitive and neural foundations of religious belief". In Proceedings of the National Academy of Sciences of the United States of America, 24, 106 (12) (March 2009): 4876-81.

${ }^{35}$ Borg, Jacqueline, Bengt Andrée, Henrik Soderstrom, Lars Farde. "The serotonin system and spiritual experiences." In American Journal of Psychiatry 16o (11) (2003): 1965-9.

${ }^{36}$ Although the sample size is small, this study does provide valuable insight into how Sikhs of all ages view mental illness.
} 
that modern biomedicine has the ability to heal people, they also recognise that there may be other ways than the medical by which to heal the mind.

Thus, there is a constant struggle between religion and science regarding disease and the mind, with religion generally trying to keep up with evidence-based scientific theory. Whereas in the past Sikhs would have attributed the cause and treatment of mental illness to divine will and an individual's spiritual inadequacies or to magical forces, today we see this mindset changing to incorporate the scientific worldview and that the treatments sought, particularly by younger, more educated Sikhs, are based on what their medical practitioner tells them rather than a religious figure. However, the ethnographic study does reveal that despite embracing modern evidence-based medicine, most religious Sikhs continue to hold to the belief that while the physical, observable causes of mental illness, such as a chemical imbalance in the brain, should be treated with modern medicine, these causes are ultimately physical manifestations of a deeper spiritual malaise.

\section{Glossary}

\begin{tabular}{ll}
$\begin{array}{l}\text { ahankar } \\
\text { Amrit }\end{array}$ & Pride \\
ardas & Holy water/nectar of immortality \\
& Sikh Prayer that opens or concludes a religious \\
prayer \\
granthi/giani & Soul \\
Gurmukh & A Sikh priest \\
& Someone who has realised God and has overcome his/ \\
guru granth sahib & The sacred text that contains the compositions of the \\
\multicolumn{1}{l}{ (GGS) } & Sikh Gurus, as well as those of Hindu and Muslim saints \\
& It is at the centre of all Sikh ceremonies and rituals \\
hukam & The will of God. \\
haumai & Ego-I-I. Self-centredness, which prevents an \\
jadoo tuna & individual from becoming a gurmukh \\
kam & Black magic \\
Khande di Pahul & Lust or Desire \\
kirat karna & Amrit Ceremony \\
kismat & Honest work
\end{tabular}




$\begin{array}{ll}\text { krodh } & \text { Anger } \\ \text { lobh } & \text { Greed/Covetousness } \\ \text { Manmukh } & \text { An individual who is ego orientated } \\ \text { maya } & \text { Greed or wealth } \\ \text { moh } & \text { Attachment } \\ \text { najjar } & \text { Evil Eye or look that can cause illness } \\ \text { nam simran/japna } & \text { Meditation on God's name } \\ \text { pangat } & \text { People sitting together in rows to show a communal } \\ & \text { meal, i.e. langar } \\ \text { Rehat Maryada } & \text { Code of Conduct } \\ \text { sangat } & \text { Religious Congregation } \\ \text { Satguru } & \text { God } \\ \text { sewa } & \text { Selfless service } \\ \text { vand chakna } & \text { Giving to those in need } \\ \text { Waheguru } & \text { Name by which Sikhs refer to God-Wonderful } \\ & \text { Lord }\end{array}$





\section{BIBLIOGRAPHY}

Ahmed, Qanta. In the Land of Invisible Women. Naperville, Illinois: Sourcebooks, Inc. 2008.

Alter, Joseph S. Yoga in Modern India. The Body Between Science and Philosophy. Princeton, NJ: Princeton University Press. 2004.

- "Yoga and Physical Education: Swami Kuvalayananda's Nationalist Project." Asian Medicine, Vol. 3: 20-36 (2007).

Anderson, Robert Mapes. "Pentecostalism." In Encyclopedia of Religion, 2nd edition, edited by L. Jones, M. Eliade, and C.J. Adams, 7028-7034. Detroit, MI: Macmillan Reference USA, 2005 .

Appiah, Kwame Anthony. Experiments in Ethics. Boston: Harvard University Press. 2008. Ardalan, Nader, and Laleh Bakhtiar. The Sense of Unity: The Sufi Tradition in Persian Architecture. Chicago: University of Chicago Press, 1971.

Aristotle. "The Metaphysics." In The Complete Works of Aristotle, 2 vols., edited by Jonathan Barnes, Book VIII, Part 6. Princeton, NJ: Princeton University Press, 1998.

Asad, Talal. "Agency and Pain: An Exploration." Culture and Religion 1 (2002), 29-6o. .Formations of the Secular: Christianity, Islam, Modernity. Stanford: Stanford University Press, 2003.

- Genealogies of Religion. Baltimore: The Johns Hopkins University Press, 1993.

Ashbrook, James B. and Carol Rausch Albright. The Humanizing Brain: Where Religion and Neuroscience Meet. Cleveland, OH: The Pilgrim Press, 1997.

Atran, Scott. In Gods We Trust: The Evolutionary Landscape of Religion. New York: Oxford University Press, 2002.

Atran, Scott and Ara Norenzayan. "Religion's Evolutionary Landscape: Counterintuition, Commitment, Compassion, Communion.” Behavioral and Brain Sciences 27 (2004): 713-770.

Aubry, Michel. Saint Païssius Vélichkovsky. Lausanne: Éditions l'Age d'Homme, 1992.

Azari, Nina P. Religious Experience as Thinking that Feels Like Something: A PhilosophicalTheological Reflection on Recent Neuroscientific Study of Religious Experience. Ph.D. Dissertation, The Illiff School of Theology, 2004.

—. "Neuroimaging Studies of Religious Experience: A Critical Review." In Where God and Science Meet, edited by P. McNamara, 33-54. Westport, CT: Praeger Publishers, 2006.

Azari, Nina P., John Missimer, and Rüdiger J. Seitz. "Religious Experience and Emotion: Evidence for Distinctive Cognitive Neural Patterns." International Journal for the Psychology of Religion 15, no. 4 (2005): 263-281.

Azari, Nina P., Janpeter Nickel, Gilbert Wunderlich, Michael Niedeggen, Harald Hefter, Lutz Tellmann, Hans Herzog, Petra Stoerig, Dieter Birnbacher, \& Rüdiger J. Seitz. "Neural Correlates of Religious Experience." European Journal of Neuroscience 13, no. 8 (2001): 1649-1652.

Baars, Bernard J. “Attention and Consciousness." In Cognition, Brain, and Consciousness: Introduction to Cognitive Neuroscience, st edition, edited by B.J. Baars and N.M. Gage, 225-254. Burlington, MA: Academic Press/Elsevier, 2007.

Babcock, Quinton, and Tom Byrne. "Student Perceptions of Methylphenidate Abuse at a Public Liberal Arts College.” Journal of American College Health, 49 (2000): 143-145.

Bado-Fralick, Nikki, and Rebecca Sachs Norris. Toying with God: The World of Religious Games and Dolls. Waco, TX: Baylor University Press, 2010.

Ballard, R. "The emergence of Desh Pardesh" In Desh Pardesh. The South Asian Presence in Britain, edited by R. Ballard. London: Hurst \& Co Publishers Ltd, 1994.

Barkan, Leonard. Nature's Work of Art: The Human Body as Image of the World. New Haven: Yale University Press, 1975 . 
Barker, Eileen. "The Church Without God and the God Within: Religiosity and/or Spirituality?," In The Centrality of Religion in Social Life, edited by Eileen Barker. USA: Ashgate. 2008.

Barlow, David H. and Vincent Mark Durand, Abnormal Psychology (Fifth Ed.) Canada: Cengage Learning, 2009.

Bar-On Cohen, Einat. "Kime and the Moving Body: Somatic Codes in Japanese Martial Arts." Body \& Society, Vol. 12, no. 4 (2006): 73-93.

Barrett, Justin L. Why Would Anyone Believe in God? Walnut Creek: Alta Mira Press, 2004.

Barrett, Lisa Feldman, and Kristen A. Lindquist. "The Embodiment of Emotion." In Embodied Grounding: Social, Cognitive, Affective, and Neuroscientific Approaches, edited by Gün Semin and Eliot Smith, 237-62. Cambridge, New York: Cambridge University Press, 2008.

Barsalou, Lawrence W. et al. "Embodiment in Religious Knowledge." Journal of Cognition and Culture 5, no. 1-2 (2005): 14-57.

Baum, Gregory. “Does the World Remain Disenchanted?” Social Research 37, no. 2 (June 1970): 153-202.

Bellah, Robert N. "Durkheim and Ritual." In The Robert Bellah Reader, eds. Robert N. Bellah and Steven M. Tipton, 150-80. Durham and London: Duke University Press, 2006.

Benjamin, Walter. Illuminations: Essays and Reflections, edited by Hannah Arendt and translated by Harry Zohn. New York: Schoken Books, 1968.

Bitton-Ashkelony, Brouria. "Demons and Prayers: Spiritual Exercises in the Monastic Community of Gaza in the Fifth and Sixth Centuries." Vigiliae Christianae 57, no. 2 (2003): 200-221.

Bloch, Maurice. “Are Religious Beliefs Counter-intuitive?" In Radical Interpretation in Religion, edited by Nancy K. Frankenberry, 129-46. Cambridge, MA: Cambridge University Press, 2002.

Bolen, Jean Shinoda. Crossing to Avalon: A Woman's Midlife Quest for the Sacred Feminine. San Francisco: HarperCollins, 1995.

Borg, Jacqueline, Bengt Andrée, Henrik Soderstrom, Lars Farde. "The Serotonin System and Spiritual Experiences." American Journal of Psychiatry, 16o, no. 11 (2003): 1965-9.

Bostrom, Nick, and Anders Sandberg. Cognitive Enhancement: Methods, Ethics, Regulatory Challenges. The Future of Humanity Institute, Oxford University, 2006.

Bouhdiba, Abdelwahab. Sexuality in Islam (A. Sheridan, trans.). London: Routledge and Kegan Paul, 1985 .

Bourdieu, Pierre. Outline of a Theory of Practice. Cambridge: Cambridge University Press, 1977 .

Bourguignon, Erika. "Introduction." In Religion, Altered States of Consciousness, and Social Change, edited by Erika Bourguignon, 3-35. Columbus, OH: Ohio State University Press, 1973.

Boyer, Pascal. Religion Explained. The Evolutionary Origins of Religious Thought. New York: Basic Books, 2001.

- Religion Explained: The Human Instincts That Fashion Gods, Spirits and Ancestors. London: Vintage, 2002.

Boyer, Pascal, and H. Clark Barrett. "Domain Specificity and Intuitive Ontology." In The Handbook of Evolutionary Psychology, edited by David M. Buss, 96-118. Hoboken, NJ: John Wiley \& Sons, 2005.

Brown, Richard, and Patricia Gerbarg. "Yoga Breathing, Meditation, and Longevity." Longevity, Regeneration, and Optimal Health: Ann. New York Academy of Sciences, 1172 (2009): 54-62.

Brown, David, and Aspasia Leledaki. "Eastern Movement Forms as Body-Self Transforming Cultural Practices in the West: Towards Sociological Perspective." Cultural Sociology, Vol. 4 no. 1 (2010): 123-154.

Bruce, Steve. Religion in the Modern World: From Cathedrals to Cults. New York: Oxford University Press, 1996. 
Budden, Ashwin. "Pathologizing Possession: An Essay on Mind, Self, and Experience in Dissociation." Anthropology of Consciousness 14, no. 2 (2003): 27-59.

Bulbulia, Joseph, and Marcus Frean. "The Evolution of Charismatic Cultures." Method and Theory in the Study of Religion 22, no. 4 (2010): 254-71.

Burger, Maya. "What Price Salvation? The Exchange of Salvation Goods between India and the West." Social Compass, Vol. 53 no. 1 (2006): 81-95.

Bushnell, William C. "Psycophysiological and Comparative Analysis Ascetico-Meditational Discipline: Toward a New Theory of Asceticism." In Asceticism, edited by Vincent L. Wimbush and Richard Valantis, 553-575. New York: Oxford University Press, 1995.

Butler, Judith. Bodies that Matter: On the Discursive Limits of Sex. New York: Routledge, 1992.

Cahn, Rael B., and John Polich. "Meditation States and Traits: EEG, ERP, and Neuroimaging Studies." Psychological Bulletin 132, no. 2 (2006): 180-211.

Caldwell, John. A. et al. "A Double-blind, Placebo Controlled Investigation of the Efficacy of Modafinil for Sustaining the Alertness and Performance of Aviators: A Helicopter Simulator Study." Psychopharmacology (Berl), 150 no. 3 (2000), 272-282.

Callois, Roger. Man, Play and Games. Translated by Meyer Barash. Urbana, Chicago: University of Illinois Press, 2001.

Campbell, Colin. The Romantic Ethic and the Spirit of Modem Consumerism Oxford, New York: Basil Blackwell, 1987.

Campbell, Heidi, and Mark Walker. "Religion and Transhumanism: Introducing a Conversation." Journal of Evolution and Technology April 14, no. 2 (2005): 1-11.

Camus, Albert. "The Myth of Sisyphus." In Basic Writings of Existentialism. edited by Gordon Marino, NY: The Modern Library, 2004.

Carr, Kevin Gray. "Making Way: War, Philosophy and Sport in Japanese Judo." Journal of Sport History, Vol. 20 no. 2 (1993): 167-188.

Cave, David. "The Role of the Authoritative in the Comparative Process," in Thomas Athanasius Idinopulos, Brian C. Wilson, and James Constantine Hanges, Comparing Religions, Possibilities and Perils? Leiden/Boston: Brill, 2006.

Churchland, Patricia Smith. Neurophilosophy: Toward a Unified Science of the Mind-Brain. Cambridge, MA: MIT Press, 1986.

Churchland, Paul M. The Engine of Reason, the Seat of the Soul. Cambridge, MA: MIT Press, 1999 .

Clark, Andy. "Where Brain, Body and World Collide." Daedalus: Journal of the American Academy of Arts and Sciences (Special Issue on the Brain) 127, no. 2 (1998): 257-80.

- Supersizing the Mind: Embodiment, Action, and Cognitive Extension. Oxford: Oxford University Press, 2008.

Clayton, Philip, and Paul Davies, eds. The Re-Emergence of Emergence: The Emergentist Hypothesis from Science to Religion. New York: Oxford University Press, 2006.

Cohen, Emma. The Mind Possessed: The Cognition of Spirit Possession in an Afro-Brazilian Religious Tradition. Oxford: Oxford University Press, 2007.

Cole, William Owen. The Guru in Sikhism. London: Darton, Longman and Todd Ltd. 1982.

Cole, William Owen and Piara Singh Sambhi. The Sikhs: Their Beliefs and Practices. London: Routledge and Kegan Paul, 1985.

Colebrook, Claire. Gilles Deleuze. New York: Routledge, 2002.

Collins, Francis. S. The Language of God: A Scientist Presents Evidence for Belief. NY: Free Press, 2006.

Collins, Randall. Interaction Ritual Chains. Princeton and Oxford: Princeton University Press, 2004.

Connemann, Bernhard. J. et al. "Donepezil and Flight Simulator Performance: Effects on Retention of Complex Skills," Neurology, September 9, 61, no. 5 (2003): 721-721.

Coogan Michael D. et al., eds. The New Oxford Annotated Bible with the Apocryphal/ Deuterocanonical Books: New Revised Standard Version, Oxford: Oxford University Press, 2007 . 
Cox, Darrel. "The Physical Body in Spiritual Formation: What God has Joined Together Let No One Put Asunder." Journal of Psychology and Christianity, 21, no. 3 (2002): 281-291.

Cox, Harvey Gallagher. Fire from Heaven: The Rise of Pentecostal Spirituality and the Reshaping of Religion in the Twenty-First Century. Reading, MA: Addison-Wesley, 1995.

Crapanzano, Vincent. The Hamadsha. Berkeley: University of California Press, 1973.

Crowell, Sam. "Attributes of the Heart that Reenchant Learning." Paths of Learning 16 (Spring 2003): 6-10.

Crowell, Sam, Renate N. Caine, and Geoffrey Caine. The Re-Enchantment of Learning: A Manual for Teacher Renewal and Classroom Transformation. Tucson, AZ: Zephyr Press, 1998.

Csikszentmihalyi, Mihaly. Flow: The Psychology of Optimal Experience. New York: Harper \& Row, 1990.

Csordas, Thomas J. "Asymptote of the Ineffable: Embodiment, Alterity, and the Theory of Religion." Current Anthropology 45, no. 2 (2004): 163-185.

-. Language, Charisma, and Creativity: The Ritual Life of a Religious Movement. Berkeley: University of California Press, 1997.

—_. "Somatic Modes of Attention." Cultural Anthropology 8 (1993): 135-56.

Cutten, George Barton. Speaking with Tongues, Historically and Psychologically Considered. New Haven, CT: Yale University Press, 1927.

d'Aquili, Eugene, and Andrew Newberg. The Mystical Mind. Minneapolis: Fortress, 1999.

Damasio, Antonio. The Feeling of What Happens: Body and Emotion in the Making of Consciousness. NY: Harcourt, 1999.

—. Looking for Spinoza:Joy, Sorrow and the Feeling Brain. San Diego, New York, London: Harcourt, Inc., 2003.

Dawkins, Richard. The Blind Watchmaker. NY: W.W. Norton, 1986.

—. The God Delusion. London: Bantam Press, 2006. . The Selfish Gene. Oxford: Oxford University Press, 1976 and 1989 .

De Caro, Mario, and David McArthur, Naturalism in Question. Cambridge, MA: Harvard University Press, 2004.

De la Fuente, José Manuel et al. "Brain Glucose Metabolism in Borderline Personality Disorder." Journal of Psychiatric Research 31, no. 5 (1997): 531-541.

De Michelis, Elizabeth. "A Preliminary Survey of Modern Yoga Studies." Asian Medicine, Vol. 3 (2007): 1-19.

Deacon, Terrence. "Emergence: The Hole at the Wheel's Hub." In The Re-Emergence of Emergence: The Emergentist Hypothesis from Science to Religion, edited by Philip Clayton and Paul Davies, 111-150. New York: Oxford University Press, 2006.

—. "Language as an Emergent Function: Some Radical Neurological and Evolutionary Implications." In Religious Narrative, Cognition, and Culture: Image and Word in the Mind of Narrative, edited by. Armin W. Geertz and Jeppe S. Jensen. London: Equinox Publishing, 2007.

—. The Symbolic Species: The Co-evolution of Language and the Brain. New York: W.W. Norton \& Company, 1997.

Deacon, Terrence, and Tyrone Cashman. "The Role of Symbolic Capacity in the Origins of Religion." Journal for the Study of Religion, Nature and Culture, Vol. 3, no. 4 (2009): 490-517.

Deacy, Christopher. "Integration and Rebirth through Confrontation: Fight Club and American Beauty as Contemporary Religious Parables." Journal of Contemporary Religion 17 (2002): 61-73.

Dehaene, Stanislas. Reading in the Brain: The Science and Evolution of a Human Invention. NY: Viking, 2009.

Dehaene, Stanislas, and Lionel Naccache. "Towards a Cognitive Neuroscience of Consciousness: Basic Evidence and a Workspace Framework." Cognition 79, no. 1-2 (2001): 1-37.

DeJaegher, Hanne, and Ezequiel Di Paolo. "Participatory Sense-Making: An Enactive Approach to Social Cognition." Phenomenology and the Cognitive Sciences 6, no. 4 (2007): 485-507.

Deleuze, Gilles. Difference and Repetition. New York, NY: Columbia University Press, 1994. 
. The Fold: Leibniz and the Baroque. Minneapolis, MN: University of Minnesota Press, 1993.

Deleuze, Gilles, and Felix Guattari. A Thousand Plateaus: Capitalism and Schizophrenia. Minneapolis, MN: University of Minnesota Press, 1987.

What is Philosophy. New York, NY: Columbia University Press, 1994.

Descilo, Teresa et al. "Effects of a Yoga Breath Intervention Alone and in Combination With an Exposure Therapy for Post-traumatic Stress Disorder and Depression in Survivors of the 2004 South-East Asia Tsunami." Acta Psychiatrica Scandinavica 12, no. 4 (2010): 289-300.

Detweiler, Robert. Breaking the Fall: Religious Readings of Contemporary Fiction. San Francisco: HarperCollins, 1989.

Dietrich, Arne. "Functional Neuroanatomy of Altered States of Consciousness: The Transient Hypofrontality Hypothesis." Consciousness and Cognition 12, no. 2 (2003): 231-56.

- Introduction to Consciousness. New York: Palgrave Macmillan, 2007.

. "Neurocognitive Mechanisms Underlying the Experience of Flow." Consciousness and Cognition 13, no. 4 (2004): 746-61.

Dreyfus, Georges. "Session 3: Emotion." In Mind and Life XI: Investigating the Mind: Exchanges between Buddhism and the Biobehavioral Sciences on How the Mind Works. Kresge Auditorium, Massachusetts Institute of Technology, Cambridge, MA, 2003.

Dreyfus, Hubert and Sean Dorrance Kelly. All Things Shining: Reading the Western Classics to Find Meaning in a Secular Age. NY: Free Press, 2011.

Durkheim, Émile. The Elementary Forms of Religious Life. New York: Free Press, 1965.

Dusenbery, Verne A. 1988, "Punjabi Sikhs and Gora Sikhs: Conflicting Assertion of Sikh Identity in North America." In Sikh History and Religion in the Twentieth Century, editors Joseph T. O'Connell et al., 334-55. Toronto: Centre for South Asian Studies, University of Toronto, 1988.

Ehrlich, Paul. R. Human Natures: Genes, Cultures, and the Human Project. Washington D.C. \& Covelo, California: Island Press, 2000.

Eliade, Mircea. "Cultural Fashions and the History of Religions," in Symbolism, the Sacred, and the Arts. Edited by Diane Apostolos-Cappadona. NY: Crossroad, 1985.

Elior, Rachel. Contemporary Jewish Religious Thought. New York: Collier Macmillian Publishers, 1972.

Engebretson, Joan. "Culture and Complementary Therapies." Nursing \& Midwifery, 8, (2002): 177-184.

Englund, Harri, and James Leach. "Ethnography and the Meta-Narratives of Modernity (1)." Current Anthropology 41, no. 2 (April 2000): 225.

Epstein, Seymour. Manual for the Constructive Thinking Inventory. Amherst, MA: University of Massachussets, 1993.

Erndl, Kathleen M. "The Devi Jagrātā in Contemporary Panjabi Hinduism." Journal of the American Academy of Religion 59, no. 2 (1991): 339-36o.

Evans-Pritchard, Edward E. Witchcraft, Oracles and Magic among the Azande. Oxford: Oxford University Press, 1976.

Ewing, William A. Inside Information: Imaging the Human Body, London: Thames and Hudson, 1996.

Farah, Martha et al. "Neurocognitive Enhancement: What Can We Do and What Should We Do?" Nature, May 5 (2004): 421-425.

Fayard, Carlos, Melissa J. Pereau, and Antonia Ciovica. "Love the Lord With All Your Mind': Explorations on a Possible Neurobiology of the Experience of God and Some Implications for the Practice of Psychotherapy." Journal of Psychology and Christianity 28:2 (2009): 167-181.

Feynman, Richard P. The Pleasure of Finding Things Out. Cambridge, MA: Perseus, 1999.

Fitzgerald, Frances. "Come One, Come All." The New Yorker, Dec. 3. 2007, 46-56.

Fitzgerald, Timothy. The Ideology of Religious Studies. New York: Oxford University Press, 2000. 
Flanagan, Owen. The Problem of the Soul: Two Visions of Mind and How to Reconcile Them. New York: Basic Books, 2002.

- The Really Hard Problem: Meaning in a Material World. Cambridge: MIT Press, 2007.

Flynn, Maureen. "The Spiritual Uses of Pain in Spanish Mysticism." Journal of the American Academy of Religion 64, no. 2 (1996): 257-278.

_ _. "Taming Anger's Daughters: New Treatment for Emotional Problems in Renaissance Spain." Renaissance Quarterly 51, no. 3 (1998): 864-886.

Fontaine, Jean La. The Devil's Children. Surry, UK: Ashgate Publishing Limited, 2009.

Ford, Dennis. The Search for Meaning, A Short History. Berkeley, CA: University of California, Press, 2007.

Försterling, Friedrich. "Kelley's Covariation Model." In Encyclopedia of Social Psychology, edited by Roy F. Baumeister and Kathleen D. Vohs, 517-519. Thousand Oaks, CA: Sage Publications, 2007.

Freeman, Walter. How Brains Make Up Their Minds. London: Phoenix House, 2000.

—. "The physiology of perception." Scientific American 264 (1991): 78-87.

Frith, Chris D. et al. "Willed Action and the Prefrontal Cortex in Man: A Study with PET." Proceedings: Biological Sciences 244, no. 1311 (1991): 241-246.

Fulford, Tim. "Conducting the Vital Fluid: The Politics and Poetics of Mesmerism in the 179os." Studies in romanticism 43:1 (2004): 57-79.

Funakoshi, Gichin. Karate-do kyohan. Tokyo, New York, San Francisco: Kodansha International, 1973 .

-. Karate-Do: My Way of Life. Tokyo: Kodansha International, 1984.

Fuster, Joaquín M. "The Prefrontal Cortex-An Update: Time is of the Essence." Neuron 30, no. 2 (2001): 319-33.

- The Prefrontal Cortex. Boston: Academic Press/Elsevier, 2008.

Gallagher, Shaun. "Dynamic models of body schematic processes." In Body Image and Body Schema: Interdisciplinary Perspectives on the Body, edited by Helena De Preester and Veroniek Knockaert, 233-52. Amsterdam, Philadelphia: John Benjamins Publishing Company, 2005.

- How the body shapes the mind. Oxford: Oxford University Press, 2005.

. "The Practice of Mind: Theory, Simulation, or Primary Interaction?" Journal of Consciousness Studies 8, no. 5-7 (2001): 83-108.

Gallese, Vittorio. "The Inner Sense of Action. Agency and Motor Representations." Journal of Consciousness Studies 7, no. 10 (2000): 23-44.

Gazzaniga, Michael S. Mind Matters: How Mind and Brain Interact to Create our Conscious Lives. Boston: Houghton Mifflin Company, 1988.

- The Mind's Past. Berkeley: University of California Press, 1998.

Gibbs, Raymond W., Jr. Embodiment and Cognitive Science. Cambridge: Cambridge University Press, 2006.

Glucklich, Ariel. Sacred Pain: Hurting the Body for the Sake of the Soul. Oxford: Oxford University Press, 2001.

Goldberg, Elkhonon. The Executive Brain: Frontal Lobes and the Civilized Mind. Oxford: Oxford University Press, 2001.

—. The New Executive Brain: Frontal Lobes in a Complex World. Oxford: Oxford University Press, 2009.

Goldberg, Ellen. "Cognitive Science and Hathayoga." Zygon Vol. 40, no. 3 (2005): 613-629.

Goldberg, Steven. Seduced by Science: How American Religion Has Lost Its Way. NY: NYU Press, 1999.

Goldman-Rakic, Patricia S., Alexander R. Cools, and K. Srivastava. "The Prefrontal Landscape: Implications of Functional Architecture for Understanding Human Mentation and the Central Executive [and Discussion]." Philosophical Transactions: Biological Sciences 351, no. 1346 (1996): 1445-1453.

Goodman, Felicitas D. "Apostolics of Yucatán." In Religion, Altered States of Consciousness, and Social Change, edited by Erika Bourguignon, 178-218. Columbus: Ohio State University Press, 1973 . 
"Phonetic Analysis of Glossolalia in Four Cultural Settings." Journal for the Scientific Study of Religion 8, no. 2 (1969): 227-239.

- Speaking in Tongues: A Cross-Cultural Study of Glossolalia. Chicago: University of Chicago Press, 1972.

Goossaert, Vincent. “Taoist Poems of the Five Night Watches.” Études chinoises XIX, no. 1-2 (2000): 249-270.

Gould, Stephen Jay. The Hedgehog, The Fox, and The Magister's Pox: Mending the Gap Between Science and the Humanities. NY: Harmony Books, 2003.

_ . "Natural Selection and the Human Brain: Darwin vs. Wallace." In The Panda's Thumb. More Reflections on Natural History, 47-58. New York: Norton, 1980.

Graham, Elaine. “Nietzsche Gets a Modem': Transhumanism and the Technological Sublime." Theology March 16, no. 1 (2002): 65-80.

Gray, Martin. Sacred Earth: Places of Peace and Power. New York: Sterling, 2007.

Greenfield, Susan. Tomorrow's People: How 21st Century Technology is Changing the Way We Think and Feel. London: Penguin Books, 2003.

Grünschlo $\beta$, Andreas. “'Ancient Astronaut' Narrations: A Popular Discourse on Our Religious Past.” Fabula 48 (2007): 1-24.

Hagner, Michael. "The Mind at Work: The Visual Representation of Cerebral Processes." In Renee van de Vall and Robert Zwijnenberg, eds. The Body Within: Art, Medicine, and Visualization. Leiden: Brill, 2009.

Hallowell, Alfred Irving. Culture and Experience. New York: Schocken Books, 1967.

Hampshire, Stuart. Spinoza and Spinozism. NY: Oxford University Press, 2005.

Hanh, Thich Nhat. Friends on the Path: Living Spiritual Communities. Berkeley, CA: Parallax Press, 2002.

Hanson, Glen, Peter J. Venturelli, and Annette E. Fleckenstein. Drugs and Society. Sudbury, MA: Jones and Bartlett Publishers, 2006.

Haraway, Donna. Simians, Cyborgs and Women and When Species Meet (PostHumanities). Minneapolis, MN: University of Minnesota Press, 2008.

- Simians, Cyborgs and Women: The Reinvention of Nature. New York: Routledge, 1991.

Harrison, Michael I. "Preparation for Life in the Spirit: The Process of Initial Commitment to a Religious Movement." Urban Life and Culture 2 (1974): 387-414.

Harrisville, Roy A., and Walter Sundberg. The Bible in Modern Culture: Baruch Spinoza to Brevard Childs. Grand Rapids, MI: Wm. B. Eerdmans, 2002.

Hart, David, B. "The Anti-theology of the Body." The New Atlantis Summer 9 (2005): $65-73$.

Hasselle-Newcombe, Suzanne. "Spirituality and 'Mystical Religion' in Contemporary Society: A Case Study of British Practitioners of the Iyengar Method of Yoga." Journal of Contemporary Religion, Vol. 20 no. 3 (2005): 305-321.

Hayes, Meg, and Sam Chase. "Prescribing Yoga." Primary Care, Vol. 37 no. 1 (2010): 31-47.

Heddendorf, Russell. From Faith to Fun: The Secularisation of Humour Cambridge, UK: The Lutterworth Press, 2009.

Heelas, Paul. The New Age Movement. Oxford: Blackwell Publishers Ltd., 1996.

- Spiritualities of Life: New Age Romanticism and Consumptive Capitalism. Malden, MA: Blackwell, 2008.

Heelas, Paul, and Linda Woodhead. Spiritual Revolution: Why Religion is Giving Way to Spirituality. Malden, MA: Blackwell. 2005.

Heidegger, Martin. The Question Concerning Technology. New York, NY: Garland, 1977.

Herrnstein-Smith, Barbara. Natural Reflections: Human Cogniton at the Nexus of Science and Religion. New Haven and London: Yale University Press, 2009.

Hobson, John Allan. The Dream Drugstore: Chemically Altered States of Consciousness. Cambridge, MA: MIT Press, 2001.

Hoffman, Valerie J. "Eating and Fasting for God in Sufi Tradition." Journal of the American Academy of Religion 63, no. 3 (1995): 465-484.

Hogue, David. Remembering the Future, Imagining the Past: Story, Ritual, and the Human Brain. Cleveland: Pilgrim, 2003. 
Hollis, Martin, and Stephen Lukes. Rationality and Relativism. Oxford: Blackwell, 1982.

Howe, D.K. "Could Yoga Become an Olympic Sport?" American Fitness, Vol. 28, no. 4 (2010.): 44-45.

Huizinga, Johan. Homo Ludens: A Study of the Play Element in Culture. Boston: Beacon Press, 1950.

Hutton, Ronald. "Modern Druidry and Earth Mysteries." Time and Mind. 2:3 (2009): 313-332.

Israel, Jonathan. "Enlightenment, Radical Enlightenment and the 'Medical Revolution,' of the Late Seventeenth and Eighteenth Centuries." In Ole Peter Grell and Andrew Cunningham. Medicine and Religion in Enlightenment Europe. Burlington, VT: Ashgate, 2007.

Ivakhiv, Adrian J. Claiming Sacred Ground: Pilgrims and Politics at Glastonbury and Sedona. Bloomington: Indiana University Press, 2001.

Jackson, John Hughlings. "The Croonian Lectures on Evolution and Dissolution of the Nervous System." British Medical Journal 1, no. 1215 (1884): 703-707.

Jackson, Michael. Things as They Are: New Directions in Phenomenological Anthropology. Bloomington, IN: Indiana University Press, 1996.

Jain, Kajri. Gods in the Bazaar: The Economies of Indian Calendar Art. Durham and London: Duke University Press, 2007.

Jay, Martin. Songs of Experience: Modern American and European Variations on a Universal Theme. Berkeley: University of California Press, 2005.

Jesus Camp. DVD. Directed by Heidi Ewing and Rachel Grady. 2006; New York, NY: Magnolia Pictures, 2007.

Jhutti-Johal, Jagbir. "The Role of Women in Their Religious Institutions: A Contemporary Account." In Sikhism and Women: History, Texts and Experience, edited by Doris Jakobsch, 234-251. India: Oxford University Press, 2010.

- Sikhism Today. London: Continuum Press, 2011.

Jhutti-Johal, Jagbir and Sukhvinder Singh Johal. "The Sikh Grand Narrative." In Palliative Care amongst South Asians, editors A.R. Gatrad et al., 83-94. London: Quay Books, 2005 .

Jordan, Gregory. "Apologia for Transhumanist Religion." Journal of Evolution and Technology February 15, no. 1 (2005): 55-72.

Judson, Horace Freeland. The Eighth Day of Creation: The Makers of the Revolution in Biology. NY: Simon and Schuster, 1979.

Jung, Carl G. Aspects of the Masculine. Princeton, NJ: Princeton University Press, 1989.

Kahn-Greene, Ellen T. et al. "The Effects of Sleep Deprivation on Symptoms of Psychopathology in Healthy Adults." Sleep Medicine 8 (2007): 215-221.

Kaplan, Stephen. "Grasping at Ontological Straws: Overcoming Reductionism in the Advaita Vedānta-Neuroscience Dialogue." Journal of the American Academy of Religion, Vol. 77 no. 2 (2009): 238-274.

Kapogiannis, Dimitrios, Aron K. Barbey, Michael Su, Giovanna Zamboni, Frank Krueger, Jordan Grafman. "Cognitive and Neural Foundations of Religious Belief." Proceedings of the National Academy of Sciences of the United States of America, 24, 106, no. 12 (March 2009): 4876-81.

Kauffman, Stuart A. Reinventing the Sacred: A View of Science, Reason, and Religion. NY: Basic Books, 2008.

Kaufman, Gordon. God The Problem. Cambridge, MA: Harvard University Press, 1972.

Keller, Catherine. "Complicities: Folding the Event in Whitehead and Deleuze" a paper delivered at Event and Decision: Ontology and Politics in Badiou, Deleuze, and Whitehead (Claremont, CA, December 7, 2007) manuscript page 2.

Kelsey, Morton T. Tongue Speaking: An Experiment in Spiritual Experience. Garden City, NY: Doubleday, 1964.

Killgore, William D.S. et al. "Sleep Deprivation Reduces Perceived Emotional Intelligence and Constructive Thinking Skills." Sleep Medicine 9, no. 5 (2008): 517-526.

Kim, Jaegwon. "Emergence: Core Ideas and Issues." Synthese, vol. 151, no. 3 (2006): 547-559. 
Kirschner, Robert. "The Vocation of Holiness in Late Antiquity.” Vigiliae Christianae 38 (1984): 105-124.

Knight, William D. et al. "The Cultural Context of Visual Hallucinations." Postgraduate Medical Journal 84, no. 988 (2008): 103-105.

Kolata, Gina. "The Scan that Didn't Scan.” The New York Times October 14, 2008.

Konvalinka, Ivana et al. "Synchronized Arousal Between Performers and Related Spectators in a Fire-walking Ritual." PNAS 108, no. 20 (2011): 8514-19.

Kort, Wesley. "Take Read": Scripture, Textuality, and Cultural Practice. University Park, PA: Penn State University Press, 1996.

Kraus, Rachel. "The Many Faces of Spirituality: A Conceptual Framework Considering Belly Dance." Implicit Religion, Vol. 12 no. 1 (2009): 51-72.

Kroll, Jerome, and Bernard Bachrach. The Mystic Mind. The Psychology of Medieval Mystics and Ascetics. London: Routledge, 2005.

Krueger, Joachim I. "Attribution Theory." In Encyclopedia of Social Psychology, edited by Roy F. Baumeister and Kathleen D. Vohs, $75^{-78}$. Thousand Oaks, CA: Sage Publications, 2007 .

Krueger, Oliver. “Gnosis in cyberspace.” Journal of Evolution and Technology August 14, no. 2 (2005): $55^{-67 .}$

Kundermann, Berndt et al. "Sleep Deprivation Affects Thermal Pain Thresholds but Not Somatosensory Thresholds in Healthy Volunteers." Psychosomatic Medicine 66 (2004): 932-937.

Kurzweil, Raymond. The Singularity Is Near. New York: Viking, 2005.

LaFleur, William R. "Body," in Critical Terms for Religious Studies, edited by Mark C. Taylor. Chicago: University of Chicago Press, 1998.

Lakoff, George, and Mark Johnson, Metaphors We Live By. Chicago and London: The University of Chicago Press, 1980.

- Philosophy In the Flesh: The Embodied Mind and Its Challenge to Western Thought. NY: Basic Books, 1999.

Larson, Ken. ReEnchantment: A Schoolboy's Adventure. Bloomington, ID: AuthorHouse, 2007.

Latour, Bruno. The Politics of Nature: How to bring the Sciences into Democracy. Cambridge, MA: Harvard University Press, 2004.

Lea, Jennifer. "Liberation or Limitation? Understanding Iyengar Yoga as a Practice of the Self." Body \& Society, Vol. 15, no. 3 (2009): 71-92.

Leavitt, John. "Meaning and Feeling in the Anthropology of Emotions." American Ethnologist 23, no. 3 (1996): 514-39.

LeDoux, Joseph. The Synaptic Self: How Our Brains Become Who We Are. New York: Viking, 2002.

Leopold, Aldo. Sand County Almanac. Oxford, UK: Oxford University Press, 1949.

Lester, Rebecca J. “Embodied Voices: Women's Food Asceticism and the Negotiation of Identity." Ethos 23, no. 2 (1995): 187-222.

Lewontin, Richard, Steven Rose, and Leon J. Kamin. 1985. Not in Our Genes: Biology, Ideology and Human Nature. New York: Pantheon Books, 1985.

Lhermitte, François "Human Autonomy and the Frontal Lobes. Part II: Patient Behavior in Complex and Social Situations: The 'Environmental Dependency Syndrome.' " Annals of Neurology 19, no. 4 (1986): 335-43.

Lindberg, Ulman et al. "Brains Swinging in Concert: Cortical Phase Synchronization While Playing Guitar." BMC Neuroscience 10, no. 22 (2009): 1-12.

Lindholm, Charles. "Creating an Anthropology of Emotion." In A Companion to Psychological Anthropology: Modernity and Psychocultural Change, edited by Casey Conerly. Oxford: Blackwell Publishers, 2004.

—. Culture and Authenticity. Malden, Oxford: Wiley-Blackwell, 2008.

Lindsay, Robert Bruce. "William Gilbert and Magnetism in 16oo." The American Journal of Physics. 8, no. 5 (1940): 271-282. 
Lisdorf, Anders. "The Effect of Ritual Action on Evaluation of Credibility in Divination." 29th Meeting of the Cognitive Science Society. Nashville, TN, 2007.

Lovekin, A. Adams, and H. Newton Malony. "Religious Glossolalia: A Longitudinal Study of Personality Changes." Journal for the Scientific Study of Religion 16, no. 4 (1977): 383-393.

Lovelock, James. Gaia: A New Look at Life on Earth. Oxford, UK: Oxford University Press, 1979 .

Luhrmann, Tanya M., Howard Nusbaum, and Ronald Thisted. "The Absorption Hypothesis: Learning to Hear God in Evangelical Christianity." American Anthropologist 112, no. 1 (2010): 66-78.

Lutz, Catherine, and Geoffrey White. "The Anthropology of Emotions." Annual Review of Anthropology 15 (1986): 405-36.

Lyon, David. Jesus in Disneyland: Religion in Postmodern Times. Malden, MA: Polity Press, 2000.

MacDonald, Jeffery L. "Inventing Traditions for the New Age: A Case Study of the Earth Energy Tradition." Anthropology of Consciousness. 6, no. 4 (1995): 31-45.

MacLean, Paul D. The Triune Brain in Evolution: Role in Paleocerebral Functions. New York: Plenum Press, 1990.

Magdalinski, Tara, and Timothy J.L. Chandler, eds. With God on Their Side. Sport in the Service of Religion. London: Routledge. 2002.

Maguire, Eleanor A., Katherine Woollett, and Hugo J. Spiers. "London taxi drivers and bus drivers: A structural MRI and neuropsychological analysis." Hippocampus 16, no. 12 (2006): 1091-101.

Malony, H. Newton, and A. Adams Lovekin. Glossolalia: Behavioral Science Perspectives on Speaking in Tongues. Oxford: Oxford University Press, 1985.

Markl, Hubert, ed. The Evolution of Social Behavior. Hypotheses and Empirical Tests. Weinheim: Verlag Chemie, 1980.

Martin, F. David. Art and the Religious Experience: The "Language" of the Sacred. Lewisburg, PA: Bucknell University Press, 1972.

Marty, Martin E. "Protestantism." In Encyclopedia of Religion, edited by M. Eliade, 74467459. New York: Macmillan, 1987.

Mathews, Peter. "Diagnosing Chuck Palahniuk's Fight Club." Stirrings Still 2, no. 2 (Fall/ Winter 2005): 81-104.

Maturana, Humberto, and Francisco Varela. The Tree of Knowledge: The Biological Roots of Human Understanding. Boston: Shambhala, 1987.

Mauss, Marcel. The Gift. London: Routledge, 1990.

—_. "Techniques of the Body." In Marcel Mauss, Techniques, Technology, and Civilisation, edited and introduced by Nathan Schlanger, 77-96. New York: Durkheim Press/ Berghahn Books, 2006.

Maxwell, Richard W. "Neurobiology of Chakras and Prayer: The Physiological Foundation of Yoga Chakra Expression." Zygon Vol. 44 no. 4 (2009): 807-824.

Mazis, Glen. Earthbodies: Rediscovering Our Planetary Senses. Albany, NY: SUNY Press, 2002.

McFague, Sallie. Models of God: Theology for an Ecological, Nuclear Age. Philadelphia: Fortress Press, 1987.

McFarland, Thomas. Romanticism and the Forms of Ruin: Wordsworth, Coleridge, and the Modalities of Fragmentation. Princeton: Princeton University Press, 1981.

McGann, Jerome J. The Romantic Ideology: A Critical Investigation. Chicago: The University of Chicago Press, 1983 .

McGuire, Meredith. "Toward a Sociology of Spirituality: Individual Religion in Social/ Historical Context," in The Centrality of Religion in Social Life, edited by Eileen Barker. USA: Ashgate. 2008.

—. "Why Bodies Matter: A Sociological Reflection on Spirituality and Materiality." Spiritus: A Journal of Christian Spirituality, Vol. 3, no. 1 (2003): 1-18.

McLain, Karline. India's Immortal Comic Books: Gods, Kings, and Other Heroes. Bloomington and Indianapolis: Indiana University Press, 2009.

McLeod, William Hew. Sikhism. London: Penguin, 1997. 
The Sikhs: History, Religion and Society. New York: Columbia University Press, 1989.

McNeill, William H. Keeping Together in Time: Dance and Drill in Human History. Cambridge, MA: Harvard University Press, 1995.

Mellor, Philip A., and Chris Shilling. "Body Pedadogics and Religious Habitus: A New Direction for the Sociological Study of Religion." Religion 40, no. 1 (2010): 27-38.

- Re-forming the body. London: Sage, 1997.

Mendieta, Eduardo. "Surviving American Culture: On Chuck Palahniuk." Philosophy and Literature 29, no. 2 (October 2005): 394-409.

Merker, Björn. "Synchronous Chorusing and Human Origins." In The Origins of Music, edited by Nils L. Wallin, Björn Merker, and Steven Brown, 315-27. Cambridge, MA: MIT Press, 2000.

Miles, Margaret. Image as Insight. Boston: Beacon Press, 1985.

Miller, Earl K., and Jonathan D. Cohen. "An Integrative Theory of Prefrontal Cortex Function." Annual Review of Neuroscience 24 (2001): 167-202.

Mills, Watson E. Speaking in Tongues: A Guide to Research on Glossolalia. Grand Rapids, MI: W.B. Eerdmans Pub. Co., 1986.

Moore, Thomas. The Re-Enchantment of Everyday Life. Sydney: Hodder and Stoughton, 1996.

Moravec, Hans, and Frederik Pohl. "Souls in Silicon." Omni 11: 66-76, 1993.

Morgan, Diane. Essential Islam: A Comprehensive Guide to Belief and Practice. Greenwood Press Publishing, 2009.

Morring, Frank Jr., ed. "Radiation Report." Aviation Week \& Space Technology, 165, no. 17 (2006): $5^{2}$.

Morris, Kelly. "Meditating on Yogic Science." The Lancet, Vol. 351 (1998): 1038.

Morsella, Ezequiel, John A. Bargh, and Peter M. Gollwitzer. Oxford Handbook of Human Action. Oxford: Oxford University Press, 2009.

Morton, Timothy. Ecology Without Nature: Rethinking Environmental Aesthetics. Cambridge, MA: Harvard University Press, 2008.

Moscivici, Serge. "The Reenchantment of the World." In Beyond the Crisis, edited by Norman Birnbaum, 133-168. New York: Oxford University Press, 1977.

Naam, Ramez. More Than Human: Embracing the Promise of Biological Enhancement. New York. Broadway Books, 2005.

Naguib, Saphinaz-Amal. "The Martyr as Witness Coptic and Copto-Arabic Hagiographies as Mediators of Religious Memory." Numen 41, no. 3 (1994): 223-254.

Nancy, Jean Luc. The Dis-enclosure of Christianity. New York, NY: Fordham, 2008.

Neda, Zoltan et al. "The Sound of Many Hands Clapping: Tumultuous Applause can Transform Itself into Waves of Synchronized Clapping." Nature 403 (2000): 849-50.

Nesbitt, Eleanor. "The Body in Sikh Tradition." In Religion and the Body, edited by S. Coakley. Cambridge: Cambridge University Press, 2000.

Newberg, Andrew, and Mark Robert Waldman. Why We Believe What We Believe: Uncovering Our Biological Need for Meaning, Spirituality, and Truth. New York: Free Press, 2006.

Newberg, Andrew, Eugene D'Aquili, and Vince Rause. Why God Won't Go Away: Brain Science \& The Biology of Belief. NY: Ballantine Book, 2001.

Newberg, Andrew et al. "The Measurement of Regional Cerebral Blood Flow During Glossolalia: A Preliminary SPECT Study." Psychiatry Research 148, no. 1 (2006): 67-71.

"The Measurement of Regional Cerebral Blood Flow during the Complex Cognitive Task of Meditation: A Preliminary SPECT Study." Psychiatry Research 106, no. 2 (2001): $113^{-22 .}$

Newcombe, Suzanne. "Stretching for Health and Well-Being: Yoga and Women in Britain, 1960-1980. Asian Medicine, Vol. 3 (2007): 37-63.

Nielsen, Greg, and Joseph Polansky. Pendulum Power: A Mystery You Can See, a Power You Can Feel. Rochester, Vermont: Inner Traditions International, 1987.

Nietzsche, Friedrich. "Composition of Thus Spake Zarathustra." In The Creative Process. Brewster Ghiselin. NY: Mentor Books, 1952.

Noë, Alva. Out of Our Heads: Why You Are Not Your Brain, and Other Lessons from the Biology of Consciousness. NY: Hill and Wang, 2009. 
Norris, Rebecca Sachs. "Examining the Structure and Role of Emotion: Contributions of Neurobiology to the Study of Embodied Religious Experience." Zygon 40, no. 1 (2005): 181-99.

. "The Paradox of Healing Pain." Religion 39, no. 1 (2009): 22-33.

Nussbaum, Martha. From Disgust to Humanity: Sexual Orientation and Constitutional Law. NY: Oxford University Press, 2010.

O'Murchu, Diarmuid. Quantum Theology: Spiritual Implications of the New Physics. New York: The Crossroad Publishing Company, 2004.

Obeyesekere, Gananath. "Depression, Buddhism, and the Work of Culture in Sri Lanka." In Culture and Depression: Studies in the Anthropology and Cross-Cultural Psychiatry of Affect and Disorder edited by Arthur Kleinman and Byron Good, 134-52. Berkeley, Los Angeles, London: University of California, 1985 .

O'Connor, Timothy, and Yu Hong Wong. "The Metaphysics of Emergence." Noûs 39 (2005): 659-679.

Olajubu, Oyeronke. "Signifying Scriptures from an African Perspective." In Theorizing Scriptures: New Critical Orientations to a Cultural Phenomenon. edited by Vincent Wimbush. New Brunswick, NJ: Rutgers University Press, 2008.

Olkowski, Dorothea. "Political Science and the Culture of Extinction." In Deleuze, Guattari, Ecology, edited by Bernd Herzogenrath, PAGES. New York: Palgrave Macmillan, 2009.

Olson, Valerie. "American Extreme: An Ethnography of Astronautical Visions and Ecologies." PhD diss., Rice University, 2010.

Opler, Morris Edward. "Themes as Dynamic Forces in Culture." The American Journal of Sociology 51, no. 3 (1945): 198-206.

Otto, Rudolf. The Idea of the Holy, translated by J.W. Harvey. Oxford: Oxford University Press, 1936.

Palahniuk, Chuck. Choke. New York: Anchor, 2001.

—. Damned. New York: Random House, 2011.

- Diary. New York: Doubleday, 2003.

—. Fight Club. New York: Owl Books, 1996.

—. Fugitives \& Refugees: A Walk in Portland, Oregon. New York: Crown Publishers, 2003 .

- Haunted. New York: Doubleday: 2005.

- Invisible Monsters. New York: W.W. Norton, 1999.

—. Lullaby. New York: Random House, 2002.

—. Rant: An Oral Biography of Buster Casey. New York: Doubleday, 2007.

—. Snuff. New York: Doubleday, 2008.

—. Stranger Than Fiction: True Stories. New York: Doubleday, 2004.

—. Survivor. New York: Anchor, 1999.

Parham, Charles. Kol Kare Bomidbar. Joplin, MO: Joplin Printing Company, 1944.

Parish, Steven M. Subjectivity and Suffering in American Culture: Possible Selves. New York: Palgrave Macmillan, 2008.

Pearce, Joseph Chilton. Biology of Transcendence: A Blueprint of the Human Spirit. Rochester, VT: Park Street Press, 2002.

Pease, Allan, and Barbara Pease. Why Men Don't Listen \& Women Can't Read Maps. London: Orion Books, 2001.

Pert, Candace. Molecules of Emotion. New York: Scribner, 1997.

Popkin, Richard. In The Cambridge Companion to Spinoza. edited by Don Garrett. NY: Cambridge University Press, 1996.

Porter, Roy. Flesh and the Age of Reason: The Modern Foundations of Body and Soul. NY: W.W. Norton \& Company, 2003.

- The Greatest Benefit to Mankind: A Medical History of Humanity. NY: W.W. Norton \& Company, 1997.

Postman, Neil. Amusing Ourselves to Death: Public Discourse in the Age of Show Business. New York, NY: Penguin Books, 2006.

Proudfoot, Wayne. Religious Experience. Berkeley: University of California Press, 1985. 
and Phillip Shaver. "Attribution Theory and the Psychology of Religion." Journal for the Scientific Study of Religion 14, no. 4 (1975): 317-330.

Purdey, Mark. "Does an Infrasonic Acoustic Shock Wave Resonance of the Manganese $3^{+}$Loaded/Copper Depleted Prion Protein Initiate the Pathogenesis of TSE?" Medical Hypotheses 6o:6 (2003): 797-820.

Pyysiäinen, Ilkka. "Cognition, Emotion, and Religious Experience." In Religion in Mind, edited by Jensine Andresen, 70-93. Cambridge: Cambridge University Press, 2001.

Rappaport, Roy A. Ritual and Religion in the Making of Humanity. Cambridge: Cambridge University Press, 1999 .

Rechtschaffen, Allan et al. 1989. "Sleep Deprivation in the Rat. Conceptual Issues." Sleep 12, no. 1 (1989): 1-4.

Remlinger, Stefanie. "Fight Club: The Most Dangerous Movie Ever?” In The Aesthetics and Pragmatics of Violence, edited by Michael Hensen and Annette Pankratz, 141-153. Passau: Verlag Karl Stutz, 2001.

Rey, Roselyne. The History of Pain. Trans. by J.A. Cadden, Louise Elliott Wallace and S.W. Cadden. Cambridge, MA: Harvard University Press, 1998.

Richerson, Peter J., and Robert Boyd. Not by Genes Alone. How Culture Transformed Human Evolution. Chicago: University of Chicago Press, 2005.

Riis, Ole, and Linda Woodhead. A Sociology of Religious Emotion. Oxford, New York: Oxford University Press, 2010.

Rocca, Michael Della. Spinoza. London: Routledge, 2008.

Rountree, Kathryn. "Performing the Divine: Neo-Pagan Pilgrimages and Embodiment at Sacred Sites." Body Society 12:4 (2006): 95-115.

Runehov, Anne L.C. Sacred or Neural? The Potential of Neuroscience to Explain Religious Experience. Gottingen: Vandenhoeck \& Ruprecht, 2007.

Ryan, Alexandra. "Globalization and the 'Internal Alchemy' in Chinese Martial Arts: The Transmission of Taijiquan to Britain." East Asia Science, Technology and Society: an International Journal 2 (2009): 525-543.

Samarin, William J. "Sociolinguistic vs. Neurophysiological Explanations for Glossolalia: Comment on Goodman's Paper." Journal for the Scientific Study of Religion 11, no. 3 (1972): 293-296.

- Tongues of Men and Angels: The Religious Language of Pentecostalism. New York: Macmillan, 1972.

Saniotis, Arthur. "Present and Future Developments in Cognitive Enhancement Technologies." Journal of Futures Studies August 14 no. 1 (2009): 27-38.

Savulescu, Julian. "Human-animal Transgenesis and Chimeras Might be an Expression of Our Humanity." The American Journal of Bioethics Summer 3 no. 3 (2003): 22-25.

Scheper-Hughes, Nancy, and Margaret Lock. "The Mindful Body: A Prolegomenon to Future Work in Medical Anthropology." Medical Anthropology Quarterly 1, no. 1 (1987): 6-41.

Schiller, Friedrich. Gedicte von Friedrich Schiller. Interpretationen, edited by Norbert Oellers. Stuttgart: Philipp Reclam, Jr, 1996.

Schleiermacher, Friedrich. On Religion: Speeches to its Cultured Despisers, translated by R. Crouter. New York: Harper \& Row, 1996.

Schmidt, Bettina E and Lucy Huskinson (eds), Spirit Possession and Trance New Interdisciplinary Perspectives. London: Continuum Press, 2010.

Schwarz, Berthold E. "Ordeal by Serpents, Fire and Strychnine. A Study of Some Provocative Psychosomatic Phenomena.” Psychiatric Quarterly 34 (1960): 405-29.

Semin, Gün R., and John T. Cacioppo. "Grounding Social Cognition." In Embodied Grounding, edited by Gün R. Semin and Eliot R. Smith, 119-47. Cambridge: Cambridge University Press, 2008.

SGPC, Sikh Rehat Maryada. Amritsar: Shiromani Gurdwara Parbandhak Committee, 1950.

Shils, Edward. "Daydreams and Nightmares: Reflections on the Criticism of Mass Culture." Sewanee Review 65 (1957): 587-6o8.

Siegel, Jerome. The Neural Control of Sleep and Waking. New York: Springer, 2002.

Singh, Avtar. Ethics of the Sikhs. Patiala: Punjabi University Publication Department, 1996. 
Singh, Gopal. Sri Guru Granth Sahib: English Version. 4 vols. Chandigarh, India: World Sikh University Press, 1978.

Slingerland, Edward. What Science Offers the Humanities: Integrating Body and Culture. Cambridge: Cambridge University Press, 2008.

. "Who's Afraid of Reductionism? The Study of Religion in the Age of Cognitive Science." Journal of the American Academy of Religion 76, no. 2 (2008): 375-411.

Smith, Benjamin R. "Body, Mind and Spirit? Towards an Analysis of the Practice of Yoga." Body \& Society, Vol. 13 no. 2 (2007): 25-46.

Smith, Christopher U.M. "Evolutionary Neurobiology and Aesthetics." Perspectives in Biology and Medicine 48, no. 1 (2005): 17-30.

Smith, Eliot R. "Social Relationships and Groups: New Insights on Embodied and Distributed Cognition." Cognitive Systems Research 9, no. 1-2 (2008): 24-32.

Sointu, Eeva, and Linda Woodhead. 2008. "Spirituality, Gender, and Expressive Selfhood," Journal for the Scientific Study of Religion, Vol. 47, no. 2: 259-276.

Song, Rhayun et al. "A Randomized Study of the Effects of T"ai Chi on Muscle Strength, Bone Mineral Density, and Fear of Falling in Women with Osteoarthritis." The Journal of Alternative and Complementary Medicine, 16, no. 3 (2010): 227-233.

Sosis, Richard. "The Adaptationist-Byproduct Debate on the Evolution of Religion: Five Misunderstandings of the Adaptationist Program." Journal of Cognition and Culture 9, no. 3 (2009): 315-32.

Spanos, Nicholas P., and Erin C. Hewitt. "Glossolalia: A Test of the 'Trance' and Psychopathology Hypotheses." Journal of Abnormal Psychology 88, no. 4 (1979): 427-434.

Spinoza, Baruch. In A Spinoza Reader: The Ethics and Other Works. edited by Edwin Curley. Princeton, NY: Princeton University Press, 1994.

_ . "The Ethics," Part I, Propositions XIV-XV. In On the Improvement of the Understanding, The Ethics, and Correspondence. Trans. R.H.M. Elwes, NY: Dover Publication, 1955.

Spittler, Russell. "Glossolalia." In The New International Dictionary of Pentecostal and Charismatic Movements, Stanley M. Burgess and Eduard M. van der Maas, eds. Grand Rapids, MI: Zondervan, 2002.

Stafford, Barbara. Good Looking: Essays on The Virtues of Images. Cambridge: MIT Press, 1996.

Stark, Rodney. The Rise of Christianity: A Sociologist Reconsiders History. Princeton: Princeton University Press, 1996.

Stewart, Charles. "Erotic Dreams and Nightmares from Antiquity to the Present." Journal of the Royal Anthropological Institute 8, no. 2 (2002): 279-309.

Strathern, Andrew. Body Thoughts. Ann Arbor: University of Michigan Press, 1996.

Strauss, Sarah. Positioning Yoga: Balancing Acts Across Cultures. Oxford: Berg. 2005.

Stroumsa, Gedaliahu G. "Shaping the Person in Early Christian Thought." History of Religions 30, no. 1 (1990): 25-50.

Sullivan, Lawrence. "Body Works: Knowledge of the Body in the Study of Religion," History of Religions, 1990.

Suzuki, Shunru. Zen Mind, Beginner's Mind. New York \& Tokyo: Weatherhill, 2001.

Synan, Vinson. The Holiness-Pentecostal Tradition: Charismatic Movements in the Twentieth Century. Grand Rapids, MI: W.B. Eerdmans Pub. Co., 1997.

Takhar, Opinderjit Kaur. Sikh Identity: An Exploration of Groups Among Sikhs. Aldershot, UK: Ashgate Publishing Limited, 2005.

Tan, Kevin S.Y. "Constructing Martial Tradition: Rethinking a Popular History of Karatedou." Journal of Sport \& Social Issues, Vol. 28 no. 2 (2004): 169-192.

Tandy, Charles. "The Education of Humans and Transhumans in the Twenty-first Century." Journal of Futures Studies November 10, no. 2 (2005): 85-96.

Taves, Anne. Religious Experience Reconsidered: A Building Block Approach to the Study of Religion and Other Special Things. Princeton \& Oxford: Princeton University Press, 2009.

Taylor, Charles. A Secular Age. Cambridge, MA: Harvard University Press, 2007. 
Sources of the Self: The Making of the Modern Identity. Cambridge, MA: Harvard University Press, 1989.

Thiering, Barbara. "The Biblical Source of Qumran Asceticism." Journal of Biblical Literature 93, no. 3 (1974): 429-444.

Tooby, John, and Leda Cosmides. "The Psychological Foundations of Culture." In The Adapted Mind: Evolutionary Psychology and the Generation of Culture, edited by Jerome Barkow, Leda Cosmides, and John Tooby, 19-136. Oxford: Oxford University Press, 1992.

Tsang, Hector, and Kelvin Fung. "A Review on Neurobiological and Psychological Mechanisms Underlying the Anti-depressive Effect of Qigong Exercise.” Journal of Health Psychology, Vol. 13 no. 7 (2008): 857-863.

Turner, Victor. The Forest of Symbols: Aspects of Ndembu Ritual. Ithaca, NY: Cornell University Press, 1967.

. "Frame, Flow and Reflection: Ritual and Drama as Public Liminality." Japanese Journal of Religious Studies 6, no. 4 (1979): 465-499.

. The Ritual Process: Structure and Anti-Structure. New York: Aldine de Gruyter, 1969.

Tuzin, Donald. "Miraculous Voices: The Auditory Experience of Numinous Objects." Current Anthropology 25:5 (1984): 579-596.

Tüzün, Şansin et al. "Yoga Might be an Alternative Training for the Quality of Life and Balance in Postmenopausal Osteoporosis." European Journal of Physical and Rehabilitation Medicine Vol. 46 no. 1 (2010): 69-72.

Valussi, Elena. "Women's Qigong in America." Journal of Daoist Studies, Vol. 3 (2010): 187-201.

Van der Veer, Peter. "Global Breathing-Religious Utopias in India and China." Anthropological Theory, Vol. 7, no. 3 (2007): 315-328.

Van Gennep, Arnold. The Rites of Passage. London: Routledge \& Paul, 1960.

Van Riper, A. Bowdoin. "What the Public Thinks it Knows About Science." European Molecular Biology Organization Reports 4, no. 12 (2003): 1104-1107.

Villamón, Miguel et al. Reflexive Modernization and the Disembedding of Jūdō from 1946 to the 2000 Sydney Olympics." International review for the Sociology of Sport, Vol. 39, no. 2 (2004): 139-156.

Vinge, Verner. "The Coming Technological Singularity." Whole Earth Review. Winter issue (1993).

Walker, Evan Harris. The Physics of Consciousness: Quantum Minds and the Meaning of Life. New York: Perseus Books, 2000.

Warner, R. Stephen. "2007 Presidential Address: Singing and Solidarity." Journal for the Scientific Study of Religion 47, no. 2 (2008): 175-90.

Waugh, Earle H. The Munshidin of Egypt. Columbia: University of South Carolina Press, 1989 .

Weber, Max. From Max Weber: Essays in Sociology. Trans. and edited by Hans H. Gerth and C. Wright Mills, 77-128. New York: Oxford University Press, 1946.

Weibel, Deana. "Of Consciousness Changes and Fortified Faith: Creativist and Catholic Pilgrimage at French Catholic Shrines," in Pilgrimage and Healing, Jill Dubisch and Michael Winkelman, eds. 111-134. Tucson: University of Arizona Press, 2005.

Whaler, K.A. "Magnetotelluric Fieldwork Adventures in Africa." Astronomy \& Geophysics: The Journal of the Royal Astronomical Society 47:2 (2006): 2.28-2.37.

Whitehouse, Harvey. Modes of Religiosity. A Cognitive Theory of Religious Transmission. Waltnut Creek: Altamira Press, 2004.

Willard, D. Renovation of the Heart: Putting on the Character of Christ. Colorado Springs, CO: Navpress, 2002.

Wilson, David Sloan. Darwin's Cathedral: Evolution, Religion, and the Nature of Society. Chicago: University of Chicago Press, 2002.

- Evolution for Everyone. New York: Delta Trades Paperbacks, 2007.

Wilson, Edward O. Consilience: The Unity of Knowledge, NY: Alfred A. Knopf, 1998. 
Winkelman, Michael. "Shamanism as Neurotheology and Evolutionary Psychology." American Behavioral Scientist 45, no. 12 (2002): 1873-1885.

Wolf, Maryanne. Proust and the Squid: The Story and Science of the Reading Brain. NY: Harper Collins, 2007.

Woodhead, Linda. "Gendering Secularization Theory," Social Compass, Vol. 55, no. 2 (2008): 187-193.

$\mathrm{Wu}, \mathrm{Ge}$, and Xiaolin Ren. "Speed Effect of Selected Tai Chi Chuan Movement on Leg Muscle Activity in Young and Old Practitioners. Clinical Biomechanics Vol. 24, no. 5 (2009): 415-421.

Wuthnow, Robert. "Cognition and Religion." Sociology of Religion. 68, no. 4 (2007): $341-360$.

Yan, Xin et al. "External Qi of Yan Xin Qigong Induces Apoptosis and Inhibits Migration and Invasion of Estrogen-Independent Breast Cancer Cells Through Suppression of Akt/ NF- $\varkappa$ B Signaling." Cellular Physiology \& Biochemistry Vol. 25, nos. 2/3 (2010): 263-270.

Yates, Joshua J. "Mapping the Good World: The New Cosmopolitans and Our Changing World Picture." The Hedgehog Review. Fall 2009: 7-27.

Young, Damon A. "Bowing to Your Enemies: Courtesy, Budō, and Japan." Philosophy East \& West, Vol. 59, no. 2 (2009): 188-215.

Young, Liane and Rebecca Saxe. "Moral Universals and Individual Differences." Emotion Review 3, no. 3 (2011): 323-324.

Young, Simon. Designer Evolution: A Transhumanist Manifesto. Amherst NY: Prometheus Books, 2006.

Zell-Tamis, Beverlee. The Day the Music Stopped: Re-enchantment of our Lost Spirit. New York: Carlisle Press, 2001.

Zimmerman, Michael. Contesting Earth's Future: Radical Ecology and Postmodernity. Berkeley, CA: University of California Press, 1994. 


\section{INDEX}

Abrahamic religions $10,120,155,158$, 160-7

acculturation $\quad 249,251$ see also enculturation

angels 57,244

animals $144,177,179,186$

ascetic practices $\quad 217-18,223-4,229$, 232-3

asceticism 11, 159, 217-20, 222-4, 229, 232-3 see also fasting; self-mortification; sleep deprivation

ascetics 221-2, 231, 233

attribution theory $76-7$

authenticity $113,115^{-17}, 130,142,147,201$, 206

\section{biotechnologies $\quad$ 155-6 \\ Black Madonna $\quad 173,176,189$}

bodily interaction(s) $81,83-5,89,100$ body, necessary for spiritual development 126

body-image $95^{-8}$

body movements $93,96-7,99$

body-schema $81,83,95^{-8,100}$

brain (see also frontal lobes; lateral frontal cortex; prefrontal cortex, scans) 1, 16n $18,23,60-4,75,78,81-4,90,94,193,198$ brain scans $16,16 n_{3}, 21,57$ computational model of 88-9 cultural fascination with $1,1 \mathrm{n} 2,4$ and embodied cognition 89,100 and emotion 110 and evolution $\quad 162$ human 48, 51, 87-9, 91, 161, 195, 233 interdependent with body and social world $8,88,91$

and language $\quad 5^{1}$

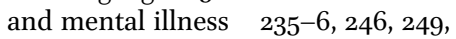
254

and mind 27

and plasticity $23,90-2$

processing images $112 \mathrm{n} 27$

and radiation $\quad 186-7$

and religion 6,25

shapes the world $25 \mathrm{n} 32$

and transhumanism 10,156

brain evolution, human 87,162

brain-machine interfaces $\quad 160-1,166$
Buddhism 39, 111n24, 112, 122, 125, 137, 156, 159, 199, 201, 203, 219

CAT 7, 16, 21, 33 see also scans

chakras 209, 241

chi 181 see also qi

Christianity $24,26,57-9,72,111,137,143$, $152,159,164,180,205,217,220-6$

cognition $8,63,81,85-90,92-4,100,107$, 226, 229, 232

cognitive science $19,27,81,85,87,94$, 157, 192, 196, 209

cognitive theories of religion 88,90 collective effervescence $82-4,96,98$

collective rituals $\quad 98-101$

Confucianism 199, 201, 203

consciousness $61,63,68,75,161,166,189$, 204, 208-9, 223, 232, 235, 237, 239, 241 altered states of $64-6,68-9,73,161$, $166,223,232$

consumer culture $7,9,113-14,120-4,127$, 212-14 see also consumerism

consumerism $113,118,120,207,212,214-15$ see also consumer culture

cosmetic neurology 16o, 166

creatives see religious creatives

culture, popular see popular culture

Damasio, Antonio $\quad 15,32,109-10,112$

Daoism 199 see also Taoists

Darwin, Charles 1, 16

Darwinism 3, 162

Deleuze, Gilles 38, 40-2, 44-5, 45n23, $46-8,52,54-5$ see also Guattari, Felix demons 218, 221-2, 225, 232-3

depression 122, 227-8, 235-6, 238, 240, $242,244,248-9,251$

discipline $109,114,123-4,126,202,209$, 217,220

disenchantment $131-4,136-7,151$

disinhibition $8,60,68-70,72-3,75$

disorders, mental 1, 235-6 see also mental illness

dissociation $65,69,74$

doctors $23,182,186,236,242,246,251$

dreams 218-19, 232-3

drugs $71,160-1$

dualism $37,54,72,88,209,211$ 
electricity $\quad 185,197$

embodied experience $\quad 8,90,92-5,98$, 100,107

embodiment 11, 39, 44, 46, 90, 92-7, 209 and cognition $\quad 84-5,100$

disconnection with religiosity $205 \mathrm{n} 18$

and enculturation 107

integrative models of 89

processes of $85,92,100$

of religious meaning 12

and spirituality 199, 206, 212

and sychronization 82

emergence $26 \mathrm{n} 37,38,48-54$

emotional intelligence 113, 229

emotional processes 53,107

emotions $7,32,91,96,105^{-14}, 117,120-7$,

206, 229, 241, 248

and authenticity 113-14, 117

and the brain 5

and Buddhism $111 n 24$

and consumerism $\quad 113-21,123,127$

and contemporary culture 105

development of 107,110

discipline of 124

easy $114,122-3$

embodiment and ritual $82,91,99$

and enculturation $\quad 9,106,109-13,121-2$, 125

and meditation $\quad 241,248$

and neuroscience $\quad 106-12$

positive 114,120

product of evolution 15

refeeling 9, 91, 107-10, 112, 123

religious $53,89 n 27,111,120$

and sleep deprivation $\quad 229$

and spirituality 206

transformative capacities $106,126-7$

transmit religious knowledge 105

enchantment 133-4, 146, 152

enculturation (see also acculturation;

emotions, enculturation of ) $1,9,62$,

$105^{-7}, 109,111,113,121,128,138,15^{2}$

energies 10, 171, 175-89, 194-8, 210, 241

see also power

magnetic $184-5$

telluric $\quad 176-7$ see also telluric forces

enframements $41-2,48$

entertainment $105,116-18,123$

environment $51,92,159,167$

evil eye $244-6,253$

evolution $81,87,90,156,158,166$

human $28,51,64,86,163$

evolutionary psychology $87,87 \mathrm{n} 20$

exercises, spiritual $\quad 209-10,213$

exorcism 245 see also spirit possession experiences

bodily 192, 199, 207, 233

hallucinatory $\quad 232-3$

facial expressions 93 see also gestures

fasting 158-9, 166, 217, 220, 223, 225, 227, 232 see also asceticism

fitness techniques 213-14, 216

five vices $238,240,248,252$

frontal lobes 61, 63, 249 see also brain

fun 105, 113-14, 116-24, 128 see also play

gender $3,39,87,246$ see also women

genes $4,15,25,27,50,87,163,230$

genetics, genetic engineering 15,23 ,

155-7

gestures 91, 93, 107, 109, 112-13, 128

see also postures

globalization 11,72

glossolalia $8,57-61,63,65-6,68-75,78$

God's name, meditation on see nam simram

Goodman, Felicitas $\quad 65^{-6,68}$

Guattari, Felix $7,38,40-2,44-5,45 \mathrm{n} 23$, 46-8, 52, 55 see also Deleuze, Gilles

Guru Granth Sahib 235-9, 241, 247-8, $25^{2}$

hallucinations 12, 229, 233 see also illusions; perceptual distortion

haumai (egotism, self-centeredness) $238-40,247,252,254$

healing $181,185,189,196,248$

health problems, mental 244, 253 see also mental illness

Hinduism 39, 120, 128, 156, 159, 199, 201-2, 207-8, 215, 219, 237, 245, 253

human body $135,163,209$

energies in $181,183^{-6,188}$

energies transformative of 171,176 , $178-9,187$

and evolution 162-3

and pain $129,140,15^{2}$

and ritual 99

in Sikhism 236-7

and spiritual transformation 159

and spirituality 200

as text 7,21

and transhumanism $\quad 155^{-6,166}$

humanism 3

illness $23,123,195,236,241,246-7$, 249-53

illusions 6o, 223, 229 see also

hallucinations 
immanence $3,38-40,42-4,46$

infrasonic waves $194-5$

inhibition $66,69,71,75$

Islam 158-9, 162, 167, 219 see also Muslim

Judaism $30,159,176,220$

judo 203-4, 206-7, 213-14

karate 203, 210-11

karma 237, 239, 246-9, 252-3

lateral frontal cortex $\quad 16-17$

ley lines $\quad 180-2$

magic, black $244-5,253$

magnetic fields 179,185

magnetism $178-9,184-7,191,195,197-8$

marketplace, spiritual-physical $\quad 212-15$

martial arts 11, 199, 201, 203-6, 210, 213, 216

materialism $37,105,128$

perspective on body $\quad 126-7$

materiality of text 33

meaning-making $\quad 7-8,41,53,55$

practices $39-41,45^{-8,55}$

process $48,52,54$

medical/religious divide 236,242

medical treatment $\quad 248-51,253$

medicine $24,140,210,235,239,248,250$

modern $7,138,140,150,253-4$

meditation $12,69,106,122,156,15^{8-9}, 181$, $218,236,242,248$

on God's name see nam simram

memory $\quad 61-2,64,106-8,110,112,161,232$

new emotional 91, 109

mental illness 2, 12, 235-54 see also

disorders, mental

treatment of $251-2,254$

mental representations $87-8,93-4$

mental states 12, 63, 66, 98, 240 see also consciousness; mental illness

Mesmer, Franz Anton 185-6

microwaves $176,189,191,195,198$

mind-bodies $\quad 26,33-5$

mindfulness 126,128

modernity $10,131,133-4,153,205 \mathrm{n} 17$

monks 221-4

MRI 5, 7, 16 see also scans

Muslim 162, 197, 237, 244, 253 see also Islam

najjar see evil eye

nam simram (meditation on God's name)

$12,239-41,247,25^{2}$

natural order $155,162-4,166$ natural selection $16,162-3,166,196,233$

natural world $4,30-1,33,35,3^{8-41}, 5^{0}$,

210

naturalism $3,7,19,28,139,153,166$

naturalized body $1-2,82,105,114,121$, 124-7

nature, divine $\quad 31,164-5$

neural activity $\quad 25,86,89$

neurobiology $1-2,6,21,24,27-8,30,85$,

$89,112,192-4,200,209-10,212,231$

neurology, cosmetic 160,166

neuroscience $15,18,21,25,35,76,82-3$,

$105^{-12,127,193,196,209,240,249,25^{2}}$

pain $9-10,16,21,106,108-9,122,129-31$,

$135,138-43,146-53,183,224,228,239$,

242

enculturated, subjective 130,139

physical 9, 124, 129-31, 138-9, 141-2, $144,148,151,153$

passion $9,70,106,115^{-17}, 121,125,128$, 219, 223

Pentecostalism $58-9,61,71-3,75,78$

Pentecostals $8,58,60,68,72,74$

perception $18,23,63,81,84,92-5,98$, $107,186,194-5$

sensory $89,93,96-7,163$

perceptual distortions $\quad 223,227,229$

see also hallucinations

perfection 31-2, 159, 164

PET $7,16,21,33$ see also scans

philosophy, transhumanist $163-4,166-7$ see also transhumanism

physical body 124, 126, 158, 184, 199

physical exercises 199-201, 203-7, 211-13, 216, 242

pilgrimage $171,173,175,197$

pilgrims $10,171-2,175^{-7}, 181,183^{-4}$,

188-9, 192, 194-5, 197-8

creativist $179,190-1,194-5,198$ see also religious creatives

plants $45,178,183,197$

play 118-21 see also fun

popular culture 113, 190-1 see also

consumer culture; consumerism

post-secularization $\quad 205,207,214$

Posthumanism 157-8

postures $92-3,95,107,113,127-8$ see also gestures

power 118, 177, 181, 187, 190 see also energies

prefrontal cortex $\quad 8,60-5,74-5$ see also brain

qi 210 see also chi 
radiation $10,178-9,182,184-7,189-90$, 197-8

radiesthesia $180-4,186$

rationalization $10,131,133-4,136,140-1$, 144, 205n17

reductionist $5,8,105,107,127,209$

reenchantment $131-6,140,144,146,150$, $15^{2-3}$

refeeling 9, 91, 107-10, 112, 123 see also emotions

religiotainment $105,118,123-4$

religious bodies 38

religious communities $7-8,26,30,34$, 218, 251-3 see also Sikh community

religious creatives $171-2,175^{-6}, 178-9$, 181, 184, 190-1, 194-5, 197-8 see also pilgrims, creativist

religious disciplines $7,122,124,126-8$ see also asceticism

religious identity 123

religious knowledge $\quad 5,106,109,123$ transmission of $105,107,112 \mathrm{n} 27$

religious meaning $1,5^{-6}, 8,12$

religious rituals $81,83,90-1,100-1$ see also rituals

religious states 107,123

transmission of 107,112

ritual behavior $8,65,94,101,171$

ritual interaction $\quad 93-4,98$

ritual participants $8,84,93,97-8,100$

ritual performance $8,91,95,97,99-100$, 111

ritual practices $\quad 57,68-72,75,82$

ritual synchronization $8,96,98,100$

rituals $8,53,82,93,95^{-6}$

collective $\quad 98-101$

embodied experience $\quad 95,97,100$

and enculturation $\quad 91,107,109,111-12$ and energy 188

integrative model of 82

new approaches to study of 57

and play $119-20$

posture and gesture 92, 107, 109

shape bodies 38

and spontaneity 71

synchronizing $8,82-4,95,98,100$

Wiccan 188

Rocamadour (France) 10, 171-7, 182-3,

188-9, 194-5, 197-8

romanticism 108, 115, 134-6

sacred sites $7,10,171-2,175,180-1,184$, 188-90, 192, 197

saints $143,224,237,239$ scans 7, 21, 33 see also brain, brain scans; CAT; MRI; PET

Schiller, Friedrich $\quad 134-5$

science $19,22,34,50,86,172,184,192$, 196,235

cultural fascination with 200, 207, 215

and mental illness 253

modern $1,6,8,15,18,27,50,191,207-8$

and reductionism 38

and religion $2,4-5,172,190-2,196$, 198, 207, 211, 231

western 208, 211, 213

science/religion debate 12, 235

scripture $7,15^{-16,18-30,32-5,72,237}$

see also Sikh scriptures; text

as authoritative $25 \mathrm{n} 34$

embodiment of 26

replaced as a source of meaning $20 n 16$

self-mortification $\quad 217,220,222,224,232$

see also asceticism

sensation $45,62,89,108,130,183,193-4$, 198-9

Shinto 199, 201, 203

shrine $172,175^{-6,187,194}$

Sikh community $12,236,244-5,253$

Sikh scriptures $\quad 237-8,244$

Sikhism 236-7, 240-1, 252

Sikhs $1,12,235^{-47}, 249,251,253$

older 12, 244, 246, 248-9, 251, 253

young $243,249-51,253$

singularity $156-7$

sleep 11-12, 217-22, 224-9, 232-3 see also wakefulness

REM 64

sleep deprivation 11-12, 217-34

somatic experiences 183,198 see also embodiment

somatic states 97 see also embodiment speaking in tongues see glossolalia

speech, glossolalic $66,68,74$ see also glossolalia

Spinoza, Baruch $\quad 3,7,24,30-1,31 n_{52}$, $3^{2-4}, 3^{8}, 45 \mathrm{n} 23$

spirit possession $\quad 244-5,253$ see also exorcism

spiritual development $10,122,126,128$ body necessary for $\quad 126$

spiritual imbalances $238-9$

spiritual-physical exercises 200-1, 211-16

spiritual-physical marketplace $\quad 212-15$

spiritual transformation

and the body $126,155,159$

and pain 124, 139

and transhumanism 10 
spirituality $3,11,192,199,199 n 1,200-1$, 204-6, 212-14, 216, 248

and body 199, 201, 215

sport 152, 201n6, 204

states, heightened 156, 161 see also consciousness, altered states of

stigma 12, 236, 247

stimuli, emotionally competent $110-12$, 123,127

stress $239,242,249$

subjective experiences $5,79,180,192-3$, 240

subjectivity $44 \mathrm{n} 18,45,72,76,198,200$, 215

substance, Spinoza's concept of $30-2,34$

suffering $9-10,22,46,129-31,138-53,221$, 224, 226-30, 239-40, 242, 247-8, $25^{1}$ inauthentic $146-52$

Sufism 111, 156, 158-9, 161, 164, 219-20

supernatural $6,29,159,172,177,187,194$, 223-4, 232, 246 agents $195^{-6}$

synchronization $84,95,97-8,101$ embodied $82-5,100$

synchronized ritual behavior 81,84 , 98-101

synchronizing effects $83,94,97-9$

taijiquan 200-1, 204, 206, 210, 213-14

Taoists 218-19 see also Daoism

techniques $70,156,160,166,202,222$ see also asceticism; spiritual-physical exercises

technology $38,44,156-8,161-3,166,183$ telluric forces see energy, telluric text $18,20-3,33,34 \mathrm{n}_{5} 8,233$ see also

scripture

theosis 165,167

tongues, gift of $5^{8-9}$ see also glossolalia

trance $65^{-6,68-9}$

transcendence $\quad 6,43,46,165$

attaining $10,155,157,159,161,163,165$, 167

neurological basis of 6

transcendent anthropology $\quad 39-40$

transhumanism 1, 10, 155-66 see also philosophy, transhumanist

Tweed, Thomas 46

vigils 219, 222, 224-6

violence $47,55,131,142$

liberating and salvific $143 n 31$

visions 222, 229 see also hallucinations

Vivekananda, Swami $\quad 207-8$

volition $61,64,74$

wakefulness $217,219-20,222,232$ see also sleep; sleep deprivation

Weber, Max 125, 131-2, 134-6, 142

women 40, 87, 248-50 see also gender

xenoglossia $\quad 57,59$

yoga 11, 189, 199-202, 205-9, 213-16, 241-2, 248, 251

Ashtanga 202, 212, 216

Bikram 204, 212, 216

Iyengar $202,212,216$

Kundalini 241-2

modern 201-2, 216 
